\title{
IMIGRAÇÃO,
}

COMPLEXIDADE E DESIGN

Vilma da Silva Vilarinho

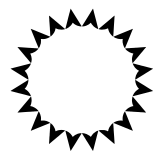

Programa de pós-graduação FAUUSP Doutorado Área de Concentração Design e Arquitetura Linha de Pesquisa

Projeto, Processos e Linguagens em Design Orientadora Profa. Dra. Daniela Kutschat Hanns 



\section{IMIGRAÇÃO, COMPLEXIDADE E DESIGN}

Vilma da Silva Vilarinho

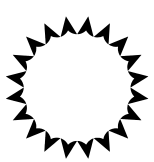

Programa de pós-graduação FAUUSP Doutorado Área de Concentração Design e Arquitetura Linha de Pesquisa

Projeto, Processos e Linguagens em Design Orientadora Profa. Dra. Daniela Kutschat Hanns 
Autorizo a reprodução e divulgação total ou parcial deste trabalho, por qualquer meio convencional ou eletrônico, para fins de estudo e pesquisa, desde que citada a fonte.

Catalogação na Publicação

Serviço Técnico de Biblioteca

Faculdade de Arquitetura e Urbanismo da Universidade de São Paulo

Vilarinho, Vilma da Silva

IMIGRAÇÃO, COMPLEXIDADE E DESIGN / Vilma da Silva

Vilarinho; orientadora Daniela Kutschat Hanns. - São Paulo,

2019 .

233.

Tese (Doutorado) - Faculdade de Arquitetura e Urbanismo da Universidade de São Paulo. Área de concentração: Design e Arquitetura.

1. Design. 2. Complexidade. 3. Sistemas. 4. Refúgio Sírio. I. Hanns, Daniela Kutschat, orient. II. Título.

Elaborada eletronicamente através do formulário disponível em: 〈http://www.fau.usp.br/fichacatalografica/〉 
VILMA VILARINHO $\mathbf{5}$ 


\section{AGRADEÇO}

a minha orientadora e amiga Profa. Dra. Daniela Kutschat Hanns por me deixar livre para pensar e construir minhas ideias. Muito do que hoje sei veio de suas perguntas e generosidade em ouvir minhas respostas.

a Marlyvan Alencar, usando as palavras do escritor Mia Couto, "obrigada or me dar de presente o tempo para pensar". Sem ele e sem você, eu não teria chegado onde cheguei.

aos Professores Doutores, Edmilson Felipe da Silva e Eduardo Cardoso Braga pelas contribuições na primeira etapa desse trabalho, por ocasião da banca de qualificação.

\section{DEDICO}

Este trabalho à minha mãe Olímpia Vilarinho, que sem conhecer a dimensão acadêmica deminha pesquisa, sabia de algum modo que ela me levaria a novos lugares. 
8 FAUUSP TESE DE DOUTORADO MIGRAÇÃO, COMPLEXIDADE E DESIGN 
ACN - Aid to the Church in Need/Fundação Pontifícia da lgreja Católica ACNUR - Alto Comissariado das Nações Unidas para Refugiados CPPC - Conselho Português para a Paz e Cooperação EUA - Estados Unidos das Americas IBGE - Instituto Brasileiro de Geografia e Estatística IBGE - Instituto Brasileiro de Geografia e Estatística IDCM -Centro de Monitoramento de Deslocamento Interno IDPs - Internally Displaced Persons/ Pessoas deslocadas internamente MI - Museu da Imigração do Estado de São Paulo MIT - Instituto de Tecnologia de Masachusetes OEA - Organização dos Estados Americanos OIM - Organização Internacional da Migração

OIM - Organização Internacional para as Migrações

ONG - Organização não-governamental ONU - Organização das Nações Unidas TGS - Teoria Geral de Sistemas UNICEF - United Nations Children's Fund/ Fundo das Nações Unidas para a Infância 
10 FAUUSP TESE DE DOUTORADO MIGRAÇÃO, COMPLEXIDADE E DESIGN 


\section{ÍNDICE}

Resumo 13

Abstract .15

Introdução

1 Mundo, Complexidade e Design

1.1 Ciência e Complexidade 36

1.2 Cibernética e Sociedade 60

1.3 Design e Complexidade 68

2 Imigração no Brasil 77

2.1 A imigração de ontem sob a perspectiva da saída, da chegada e da acomodação 84

2.2 Imigração como projeto 91

2.3 Imigração de sírios na cidade de São Paulo

2.4 Primeiro fluxo - o contexto de partida e o caminho de lá para cá 99

2.5 A chegada, a acomodação e as heranças 102

2.6 Um mundo árabe dentro da cidade de São Paulo 108
3. Migração, crise e complexidade

3.1 Acontecimento

3.2 Um outro acontecimento, uma nova crise, uma outra migração

3.3 Sobre o ambiente de origem

3.4 Crise, acontecimento, causalidade e outros

3.5 Um país, uma crise, um mundo ao redor

3.6 A diáspora 146

4. Imigração, complexidade e design ....163

4.1 Caracterizando o sistema da imigração

4.2 Imigração e fronteiras

4.3 O ambiente, o imigrante e suas relações

4.4 O perfil do novo imigrante sírio 196

4.5 Imigração é rede

Emergências 
12 FAUUSP TESE DE DOUTORADO MIGRAÇÃO, COMPLEXIDADE E DESIGN 


\section{RESUMO}

imigração, complexidade e design

A presente tese tem como foco de seus estudos a organização de sistemas complexos, a partir da compreensão do fenômeno da imigração de sírios na cidade de São Paulo, um fenômeno que se caracteriza como global e com impactos distintos em contextos locais. Essas são manifestações que se ampliam em decorrência de crises que emergem de ordens diversas e colocam em pauta diversos campos de conhecimento, a necessidade de se refletir de modo profundo e ecológico sobre seus processos de conformação, os quais tomam contornos imprevisíveis e demandam por ações ágeis para a manutenção do equilíbrio do sistema social. Quando aqui se coloca o interesse, a partir do campo do design, por estudos relacionados à organização de sistemas e complexidade, é por encontrar nesses arcabouços teóricos caminhos para se refletir sobre a ação projetual do designer em contextos que apresentam problemas de ordem sistêmicas e complexas, como se configura o da imigração, que implica não somente nas circunstâncias de saída e entrada, mas também nas de permanência, nas quais se evidenciam processos de crise sobre a organização local. Para tanto, esta tese apresenta situações descritas por conceitos oriundos da Complexidade e da Teoria Geral de Sistemas, em busca de relações que permitam refletir de modo propositivo sobre possíveis encaminhamentos ao campo do design quando este se insere em contextos de projeto, cuja problematização se qualifica como sistêmica e complexa.

Palavras-chave: 1. Design, 2. Complexidade, 3. Sistemas, 4. Refúgio Sírio 
14 FAUUSP TESE DE DOUTORADO MIGRAÇÃO, COMPLEXIDADE E DESIGN 


\section{ABSTRACT}

immigration, complexity and design

The present thesis focuses on the organization of complex systems, from the understanding of the phenomenon of Syrian immigration in the city of São Paulo, a phenomenon that characterized as global and with distinct impacts in local contexts. These are manifestations that crises that emerge from various orders and different fields of knowledge, the need to reflect in a profound and ecological way about their conformation processes, which take unpredictable contours and demand for actions agile to maintain the balance of the social system. When the interest is placed here, the field of design, through studies related to the organization of systems and complexity, it is by to find in these theoretical frameworks ways to reflect on the design action of the designer in contexts that present systemic and complex problems, such as immigration, which implies not only the circumstances of exit and entry, but also in which crisis processes on local organization are evident. Therefore, this thesis presents situations described by concepts originating from Complexity and General Theory Systems, in search of relations that allow to reflect in a design field when it is part of a project problematization qualifies as systemic and complex.

Keynords: 1. Design, 2. Complexity, 3. Systems, 4. Syrian Refuge 
16 FAUUSP TESE DE DOUTORADO MIGRAÇÃO, COMPLEXIDADE E DESIGN 
0

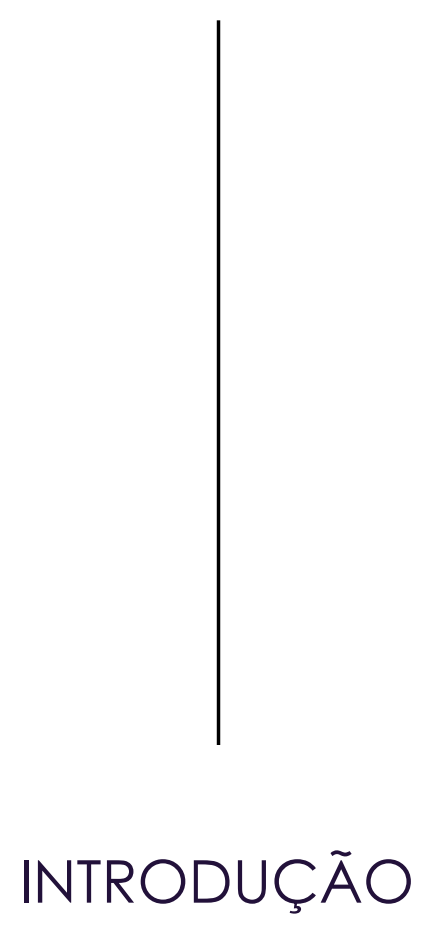

INTRODUÇÃO 
O design tem sido uma peça central na articulação entre sociedade e desenvolvimento tecnológico. Desde que surgiu, na efervescência do desenvolvimento de sistemas fabris distribuídos em larga escala em território europeu e americano, em meados do século 18 e final do 19 (CARDOSO, 2012), que seu papel passou a se evidenciar como significativo e fundamental para diversas áreas da produção humana, manifestas em produtos, processos e serviços.

Historicamente o desenvolvimento industrial promoveu uma série de transformações, entre elas, o surgimento de uma sociedade baseada no consumo decorrente de maior oferta e acesso a produtos provenientes de linhas de produção, empenhadas em disponibilizá-los em quantidades cada vez maiores, que de algum modo, provocou um declínio em seu preço final.

Um sistema que inevitavelmente entraria em colapso por seus próprios processos de retroalimentação, salvo não fossem criadas estratégias para lidar com situações de emergência. Diante desse cenário, um dos caminhos encontrados foi o de se conceber produtos com qualidades que levassem o consumidor a um outro patamar de escolha, que envolvia valores além do custo/preço, incluindo ao processo de seleção, fatores como aparência, material e qualidade do uso entre outros. Elementos de distinção que demandariam por um modo relacional de pensar o projeto de produtos. Neste contexto, o design se consolida como um espaço de pesquisa e desenvolvimento estratégico para o encaminhamento de respostas articuladas entre a indústria e as demandas sociais. 
Décadas de desenvolvimento e inovações se passaram, o mundo se transformou, novas conformações sociais emergiram, artefatos e processos foram criados e recriados para otimizar e melhorar diversas atividades do cotidiano, que se tornou complexo, tanto pelo excesso, quanto pela escassez. Em 1920 a população do Brasil era de 30.635.605, número que salta para 208,4 milhões, segundo dados divulgados pelo IBGE - Instituto Brasileiro de Geografia e Estatística em $1^{\circ}$ de julho de 2018. Esse crescimento não traz consigo somente a evidência de uma população mais numerosa, mas, essencialmente, novas qualidades em termos de conformação social.

É consenso que a cultura emerge de processos de interação, e que estas tendem a ser profusas não só pela multiplicação de seus elementos, mas também pelo que trazem de diferenças. Neste sentido, surgem rupturas e transformações, muitas das vezes imprevistas. Se olharmos para esses números pela perspectiva da gestão social, eles demandam por uma reflexão em torno da validade de instrumentos políticos, sociais e econômicos que talvez não sejam mais eficazes nos dias atuais.

A complexidade cresce e com ela emergem problemas que demandam por ações baseadas em posturas e atitudes que levem em consideração seus desdobramentos e consequências. $\mathrm{O}$ expressivo crescimento populacional, associado a exploração desenfreada dos recursos naturais, e uma irremediável crise que assola o meio ambiente colocam na pauta mundial a necessidade de ações eficazes sobre situações de escassez de alimentos, energia e água e fundamentalmente o excesso de disputa econômica em torno do petróleo como a matriz energética ainda predominante no planeta. A situação se agrava, com uma financeirização da economia que despreza mundialmente aqueles que não estão dentro desse sistema.

Tratam-se de questões globais conflituosas que precisam de olhares que as observem a partir de perspectivas dis-
IBGE - Disponível em: http://www. brasil.gov.br/noticias/cidadania-e-inclusao/2018/08/populacao-brasileira-ultrapassa-208-milhoes-de-pessoas-revela-ibge

Acesso em 24 de março de 2019. 
tintas, por serem problemas multifacetados e suas possíveis soluções não se resumem a uma resposta única. Elas demandam por vários tipos de esforços que levem em consideração o global, uma vez que são problemas sistêmicos, que não se iniciam e tão pouco se esgotam em um ponto somente.

A escassez de alimentos em determinados países invariavelmente decorre de estímulos externos, como a exploração por organizações internacionais, e se amplia para outros territórios em forma de êxodo de pessoas em busca da sobrevivência. Juntam-se a esses problemas, com características sistêmicas, as situações de guerra, de crises políticas, de conflitos religiosos, de epidemias na saúde e outras mais. Sobre esses contextos, o agravamento do quadro dá a grandeza da complexidade em questão.

Parte indissociável do desenvolvimento social, o design também se transformou e, de uma atuação sob o domínio de cenários estáticos (MORAES, 2010), no qual objetos e relações podem ser compreendidos e decodificados pela previsibilidade de um entorno que se apresenta predominantemente tangível, ocorre uma reconfiguração em direção a melhor atuar sobre os problemas que emanam de situações cada vez mais entrelaçadas. Se vive, atualmente, em um cenário híbrido, com qualidades do que é fixo, concreto e absoluto e também dinâmico, do que está em constante transformação e demanda por soluções de outra ordem -com qualidades distintas do cenário industrial, no qual a materialidade de produtos analógicos expõe a limitação dos suportes e da matéria prima.

Este outro momento, se conforma a partir do excessivo número de dados e soluções que são registrados, processados, armazenados, disponibilizados e acessados em tempo cada vez mais simultâneo e não mais a partir de um ponto fixo, mas de qualquer lugar, a qualquer momento e por todos aqueles que estejam envolvidos direta ou indiretamente. 
O atual contexto se evidencia pela adoção crescente de produtos digitais, que dão acesso a ambientes de consumo de bens e serviços, de entretenimento, do trabalho e estudo remoto, de consultas sobre o trânsito, o clima etc. Sistemas que populam dispositivos eletrônicos sob a promessa de tornar a vida mais fácil e sob um controle baseado na previsibilidade digital e conectiva. Essas são tecnologias muito mais poderosas e flexíveis do que os seus correspondentes anteriores e, por este motivo, são disruptivas.

Sobre esses novos produtos e seus desdobramentos sociais, o sociólogo Manuel Castells diz que "ao transformarem os processos de processamento de informação, as novas tecnologias da informação agem sobre todos os domínios da atividade humana". Se constrói um ambiente propício ao "estabelecimento de conexões infinitas entre diferentes domínios, assim como entre os elementos e agentes de tais atividades" complementa ele (1999, p. 120).

Esta tese parte do pressuposto que o design é um dos espaços de reflexão e proposição mais aptos a intervir, via um pensamento complexo, sobre problemas que emergem de um mundo em expansão e retração profusas. Sobre as novas conformações sociais, anteriormente sinalizadas por Castells como aquelas que afetam domínios da atividade humana, o sociólogo e teórico da comunicação, Derrick de Kerckhove (1997) chama a atenção para a necessidade de se ter profissionais que saibam intervir no crescente ambiente de interconexão em que o mundo tem se transformado. Qualidade de um ambiente que cria condições para a emergência de transformações em escala global, o que faz com que acontecimentos de antes, de um mundo sem conexões generalizadas, sejam considerados como elementos de uma cadeia causal de abrangência transnacional, sendo todos compreendidos como parte de um mesmo conjunto.

Sobre este fluxo de transformações, em relação ao papel social do design, Rafael Cardoso (2012) chama atenção 
para a sua própria natureza, que se qualifica como um espaço de reflexão sobre movimentos e transformações sociais e que este, inevitavelmente, também se ampliará. Há na configuração do design a abertura, segundo Cardoso, para o diálogo "em algum nível com os outros campos do conhecimento" (2012. p. 234). Um modo de operação imprescindível àquele que se propõe a pensar e agir em contextos complexos.

Considerando a relevância do papel social do design, esta investigação busca estabelecer e ampliar o diálogo entre o o design e conhecimentos advindos da teoria geral de sistemas e da complexidade, por identificar nesses arcabouços teóricos contribuições ao design quando atua sobre problemas decorrentes da emergência de fenômenos sociais que se qualificam como sistêmicos e complexos.

O conceito de crise pelo viés da complexidade, no qual tudo está interligado, coloca ao design o desafio de reunir conhecimentos para se pensar em problemas globais de modo sistêmico, problemas que de acordo como Edgar Morin (Fronteiras do Pensamento, 2013), são difíceis de serem concebidos, por ser a globalização um processo rápido, sobre o qual há um descompasso do conhecimento sobre os acontecimentos que emergem em seu fluxo. Colocar-se diante de situações em curso requer uma mudança no modo de pensar que considere a relação entre aquilo que caracteriza o todo. Aqui reside uma das justificativas desta pesquisa, buscar na teoria geral de sistemas e na complexidade fundamentação para a concepção de um modo de pensar sobre o todo. Um todo cujo estado é o de transformação.

O estado de transitório, em processo, em vias de, que caracteriza determinados fenômenos globais, como o das imigrações por motivos variados, provoca incerteza e desestabilização ao modo de pensar de uma ciência, como a ciência clássica, baseada na busca por respostas fecha- 
das, quando o que se tem como objeto disparador da crise se apresenta como difuso e incerto. Segundo Morin, está no pensamento complexo um caminho para "enfrentar a incerteza" e desta voltar-se sobre circunstâncias adversas. Diz ele, é possível que se construam “estratégias” para se reorganizar dentro das incertezas do mundo (apud VASCONCELLOS, 2013, p. 77). O pensamento complexo, desse modo, é mais do que ciência e filosofia, é uma via de articulação entre as esferas dos saberes. A proposta aqui defendida é que a o design traz a essa articulação a possibilidade da ação concreta, do projeto como prática consciente.

O sociólogo Michel Agier (2015), ao tratar da questão do crescimento das migrações em decorrência de crises mundiais, chama a atenção para a necessidade de desacelerar e buscar compreender o desafio em sua complexidade, de modo que se tenha um ambiente favorável a se pensar sobre circunstâncias globais para uma ação eficaz em contextos locais. Um paradoxo diante da aceleração do contemporâneo, que demanda por soluções rápidas para crises em curso. Por este motivo é tão difícil lidar com a complexidade da globalização. Compreendê-la para uma ação propositiva requer habilidade do pensamento, tempo e instrumentos adequados ao estudo da estrutura do problema em questão.

Esta tese apresenta um estudo e reflexão sobre sistemas complexos a partir do fenômeno da imigração, particularmente da Síria, considerando que esta se apresenta como uma situação global e complexa, com números expressivos e em expansão. Segundo a ACNUR - Agência da ONU para Refugiados, em temos gerais, o deslocamento da população em situação de refúgio cresceu consideravelmente nas últimas décadas, chegando ao número de 60 milhões de pessoas ao redor do mundo em decorrência de conflitos, perseguições e violações de direitos humanos . Com este estudo, se espera compreender como este
Cartilha ACNUR - protegendo refugiados no Brasil e no mundo (2016) Disponível em: https://www.acnur.org/ fileadmin/Documentos/portugues/ Publicacoes/2018/Cartilha_Protegendo_Refugiados_No_Brasil_2018.pdf?file=fileadmin/Documentos/portugues/ Publicacoes/2018/Cartilha_Protegendo_ Refugiados_No_Brasil_2018

Acesso em 13 de março de 2018. 
fenômeno se insere na contemporaneidade, como traduz uma situação de crise, como se torna complexo e como o design pode se colocar eficazmente como capaz de engendrar respostas via uma concepção de pensamento que promova o entendimento de suas dinâmicas particulares, com base num pensamento sobre organizações sistêmicas e complexas.

A reflexão a seguir se justifica pelo comprometimento em aprofundar conhecimentos que possam contribuir para uma atuação do design sobre problemas sociais, qualificados como complexos e sistêmicos. Acredita-se que o estudo sobre contextos dessa natureza promova o desenvolvimento de uma consciência e de uma prática mais dialógica com as demandas sociais.

Em busca desse objetivo, a metodologia utilizada na pesquisa consiste em: revisão de bibliografia; levantamento e estudo de documentos que versam sobre migração; banco de dados de instituições oficiais que lidam com a questão da migração e imigração: Alto Comissariado das Nações Unidas (ACNUR), Comitê Nacional para os Refugiados (CONARE); banco de dados da pesquisa "Refugiados Sírios em São Paulo", do Observatório das Migrações em São Paulo; pesquisa em ambiente digitais (sites de ONG's, Grupos de apoio ao refugiado, documentários online, redes de relacionamentos, etc.)

Os capítulos se dividem em três blocos: o primeiro de introdução ao tema principal da tese a questão da Complexidade; o segundo tem papel de contextualização do tema: imigração, imigração no Brasil e em São Paulo, e por fim, a crise Síria, que emergiu como um dos maiores conflitos armados da atualidade. O terceiro e último capítulo aborda o fenômeno da imigração síria na cidade de São Paulo, que acontece sob o amparo do Estatuto do Refugiado. Por fim, esta tese faz uma reflexão sobre as contribuições do estudo do fenômeno, pela perspectiva da complexidade do design. 
Niklas Luhmann, em seu livro "Introdução à teoria dos sistemas", diz que "os impulsos mais importantes para entender a sociedade moderna surgiram fora do campo da sociologia" (1995, p. 36). É sob este pensamento que esta tese convida à uma discussão, considerando o design como uma área de pesquisa e desenvolvimento que busca responder às necessidades das pessoas no tempo presente e futuro, se tornando um dos principais atores de um sistema/mundo que, para se manter diante do surgimento de crises, necessita se atualizar para transpor novas demandas que delas decorrem.

Respostas para essas emergências, que surgem muitas vezes de improváveis interações, não estão sob o domínio de tópicos no âmbito de um conhecimento específico, mas muito provavelmente de vários deles. Se encontra, nesse sentido, relevância na busca por assuntos passíveis de abstração, nos quais sejam identificados e obtidos conteúdos significativos para o design, que possam ser utilizados como chaves para novas concepções frente a novos desafios. É certo que questões emergentes e com qualidades complexas clamam por respostas provenientes de um modo de pensar e agir em consonância com suas estruturas, mas que possam ser ampliadas além do que se entende como o que as consideram como unidade para o que a constitui como relação. 




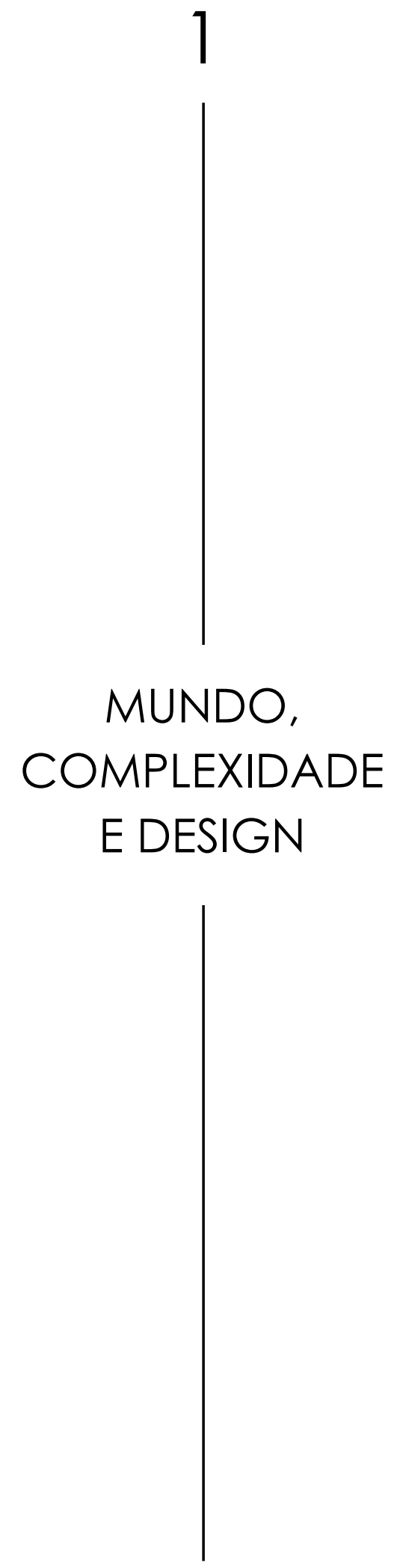



Afirmar que o mundo é complexo é um exercício meramente tautológico, na medida em que possíveis contestações seriam imediatamente negadas. A clássica posição que, em algum momento da produção do pensamento ocidental, pôs em lugares separados natureza e cultura, sujeito e objeto, ciências exatas e ciências humanas, por exemplo, revelava muito mais uma disputa de poder na medida em que a natureza, numa perspectiva antropocêntrica, era para ser dominada e as ciências exatas seriam ciências enquanto as humanas estariam em débito por não terem os requisitos metodológicos $\mathrm{e}$ comprovatórios dos estudos "objetivos". Por essa perspectiva, destacam-se as especificidades, as partes em detrimento do todo e das relações entre essas partes.

Numa abordagem sistêmica, ao mesmo tempo em que se preservam as especificidades das partes estas se modificam a partir das suas relações que, por sua vez, também modificam o todo, sem que isto seja pensado simplesmente como causa e consequência. $\mathrm{O}$ mundo cósmico, biológico, geológico, social, cultural, tecnológico etc. se constitui em relação e não pode mais ser pensado como composto de elementos isolados.

Quando se considera o planeta terra, seus processos de transformação, emergência e adaptação tornam essa qualidade relacional inquestionável, assim como a de seus sistemas, como a fauna, a flora, o clima, a espécie humana e outros que, ao longo de milhares de anos, com ele se transformaram por meio de diferentes processos de retroalimentação e de busca de equilíbrio diante de perturbações constantes. 
A partir de uma visão estrutural de sua composição, o planeta apresenta sinais significativos de que sua organização acontece sob um complexo processo de interdependência de sistemas naturais - também complexos - relacionados uns com os outros de modo inseparável. Sistemas que realizam processos e que fazem emergir elementos imprescindíveis à mútua sobrevivência. A manutenção da vida de animais e seres humanos depende do consumo de alimentos em grande parte oriundos de uma agricultura atrelada às características e condições do solo e das espécies que dão vida a ele, mas também é dependente de outras camadas da atmosfera associadas como a produção de oxigênio e com ocorrência de chuvas, entre outros.

Não existe a possibilidade de conceber qualquer um dos sistemas naturais sem a presença de outro. $\mathrm{O}$ fascinante é que a relação entre eles faz emergir a diversidade. Embora cada um desses sistemas tenha seus elementos e processos particulares caracterizados por padrões, quando postos em relação uns com os outros em contextos e condições distintas não reproduzem os mesmos padrões. Isso explica porque tem-se uma variedade profusa de biomas, que vão desde florestas pluviais consideradas como o bioma mais rico e complexo da terra, por possuir mais de $60 \%$ de toda vida animal e vegetal que nela existe - até formações vegetais escassas, como as desérticas, que possuem uma alta capacidade de resistência a falta de água e nutrientes. Ambos biomas emergem da relação dos mesmos sistemas, da litosfera, hidrosfera e atmosfera, mas são completamente distintos.

Esses fenômenos acontecem dentro de um sistema exuberante de espécies que permutam com o ambiente e entre si elementos químicos, energia, matéria, espaço etc. De modo semelhante ou aproximado a esse tipo de organização, emergem os sistemas sociais, que, em termos de ambiente, acolhem a complexi-

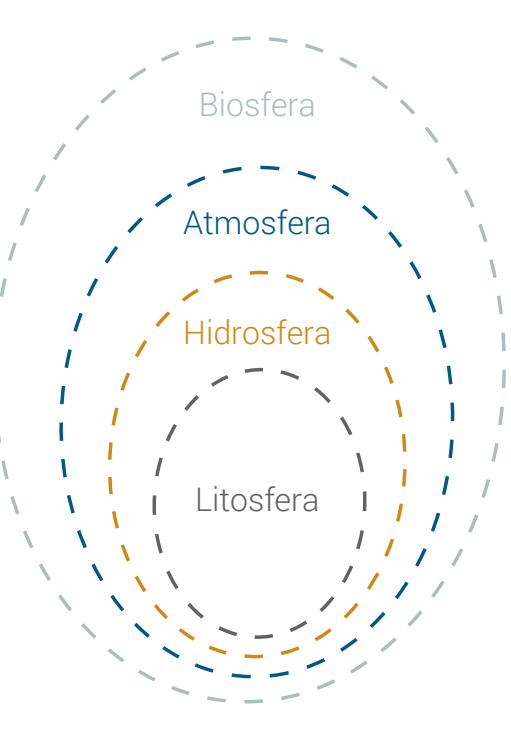

O planeta terra e seus sistemas

\section{Litosfera}

camada sólida, composta

por rochas, solo e seus relevos.

\section{Hidrosfera}

Camada líquida e de umidade,

composta pelos rios, lagos e oceanos.

\section{Atmosfera}

camada composta de gases

que circundam o planeta, como o

oxigênio e o nitrogênio.

\section{Biosfera}

Representa toda manifestação de vida do planeta.

https://www.sobiologia.com.br/conteudos/Ecologia/ Ecologia4.php\#topo

Acesso em 06 de junho de 2018 
dade relacionada ao convívio humano como a produção da cultura, da política, da economia etc. Tanto as conformações de florestas, quanto as de sociedades não surgiram de modo simples como aquilo que é descomplicado, fácil de compreender e lidar. Em geral o simples requer muito pouco para ser compreendido, dispensa grandes elaborações e associações.

Em contradição a essa concepção de simples, o que melhor define o mundo como um ambiente em transformação é a complexidade, que não por acaso tem sido, para diversos campos do conhecimento, um conceito chave para se pensar nos desafios que de algum modo nasceram no passado, marcam o presente e se projetam para o futuro como imponderáveis. Olhar para o modo como as coisas se relacionam, em função de coexistirem e permanecerem, é um processo que requer um distanciamento profundo de um tipo de pensamento que por muito tempo se organizou a partir da divisão de problemas e do isolamento de suas partes como um caminho para se acessar o conhecimento sobre eles.

Segundo Edgar Morin (1996), o simples existe para que o complexo possa ser explicado. O complexo é uma manifestação sistêmica que acontece a partir da relação de elementos que atuam por processos de interdependência e fazem emergir conformações que escapam do domínio do simples, por não serem passíveis de observação através de um olhar que as fragmente. Assim, não há como compreendê-lo sem que sua estrutura seja contemplada como um todo, afirmação que segue a de Morin, quando diz que “o complexo é tudo aquilo que não se pode reduzir a uma explicação clara, a uma ideia simples e, muito menos a uma lei simples" (TAGER 2010, p.190). O complexo emerge de relações, tendo por significado "aquilo que está ligado em conjunto, aquilo que é tecido em conjunto” (TAGER, 2010, p. 190). 
Esta é a complexidade do mundo, que se conforma não a partir de um único sistema, mas de vários e essencialmente do que emerge de cada um, da relação de um com outro e de uns com outros. Nesta linha de pensamento, os pesquisadores Thomas Berry e Brian Swimme ${ }^{1}$, que se dedicam aos estudos sobre cosmologia e consciência, afirmam que "o universo é uma comunhão de assuntos ao invés de uma coleção de objetos" (BERRY e SWIMME 1992, p. 243), ou seja, é um ambiente de relações. Esse aspecto essencial que caracteriza o mundo como um sistema complexo é também o que o coloca como um ambiente de diversidades sistêmicas.

Assim, não é o mundo que se tornou complexo. Ele o é em sua estrutura. $\mathrm{O}$ que o atualiza nesse sentido são suas emergências, que decorrem de circunstâncias distintas, interligadas e imprevisíveis, o que o torna um ambiente cuja apreensão demanda por visões também distintas, interligadas e abertas a receber o estranho e o desconhecido como portas de entrada para o enfrentamento das adversidades que acompanham o novo.

De acordo com Vasconcellos" "é preciso de fato, responder ao desafio posto pela complexidade, não só no nível da teoria, mas também da prática" (2013 p. 23), o que requer que se tenha em consideração não somente a busca de respostas para os problemas, mas essencialmente, como se chegará até elas. $\mathrm{O}$ que significa dizer que há uma necessidade de que se reconheça no complexo os modos pelos quais pode ser abordado, efetivamente, na prática.

Morin (In MENDES, 2003) destaca a necessidade de um olhar mais acurado, porém não focado. Ele aponta para a observação através do microscópio como uma característica da ciência mecanicista. O microscópio descontextualiza o objeto, o separa de seu ambiente e de sua relação com outros elementos. Ao contrário desse tipo de abordagem, para lidar com

\footnotetext{
${ }^{1}$ Thomas Berry (1914-2009)

Cosmólogo estadunidense, defensor da ecologia profunda.
}

Brian Swimme (1950) é professor de cosmologia evolucionária no programa de pós graduação em filosofia no Instituto de Estudos Integrais da Califórnia. Ambos são autores do livro The Universe Story: From the Primordial Flaring Forth to the Ecozoic Era (1992)

"the universe is a communion of subjects rather than a collection of objects"

Tradução Livre

\section{Maria José Esteves de Vasconcellos}

Pesquisadora do novo paradigma científico. Autora do livro: Pensamento sistêmico: o novo paradigma da ciência (2013). 
a complexidade, há de se estar aberto para a incerteza e para perceber a organização do que se manifesta como um todo. Trata-se, diz o sociólogo, "de um pensamento capaz de reunir, contextualizar e globalizar" ao mesmo tempo em que seja capaz de "reconhecer o singular, o individual, o concreto" (In MENDES, 2003, p. 77).

O mundo como um grande sistema aberto, vivo e entrópico demonstra sinais significativos de que está sob circunstâncias de uma complexidade crescente, seja pela escassez, seja pelo excesso. Há uma assimetria entre o expressivo crescimento populacional e o decréscimo de recursos naturais, que se acentua e coloca em pauta mundial a necessidade de ações eficazes sobre a ocorrência de futuras crises a se manifestarem em contextos essenciais como o da alimentação, da saúde, do trabalho, da energia e da água.

Trata-se de questões globais que exigem olhares que as observem em perspectivas distintas. Diante desse tipo de questão suas possíveis soluções não se resumem a uma resposta somente. Elas demandam vários tipos de esforços e abordagens que levem em consideração, seu caráter multifacetado, próprio de problemas sistêmicos que não se iniciam, e tão pouco se esgotam em um ponto somente. 


\section{1}

\section{CIÊNCIA E COMPLEXIDADE}

A todo instante tomam-se decisões que impulsionam para o futuro. Algumas resultam em comportamentos automáticos que, de tão repetitivos, pouco ou quase nada, demandam raciocínio. Andar, comer e atuar sobre as coisas cotidianas são técnicas tornadas hábitos que dispensam uma atenção concentrada. Em geral são decisões que pouco impactam em esferas que extrapolam a do espaço pessoal; seus riscos são baixos e podem ser contornados pelo próprio indivíduo.

Segundo Mauro Maldonato ${ }^{3}$ (2017), no início da civilização humana, houve o predomínio de um modelo de pensamento baseado na intuição e na rapidez como processo de criação de soluções para situações em curso. Um período onde a consciência sobre problemas predominantemente ocorria em relação a ameaças à sobrevivência e em um tempo presente, ou muito pouco além dele. A ideia de futuro era restrita. Neste período, em que tanto a organização social quanto os estilos de vida se voltavam prioritariamente à sobrevivência, "o pensamento era corpo, e o corpo era pensamento", uma reciprocidade que segundo ele, "moldou a arquitetura da mente" (MALDONATO, 2017, p. 29), que se articulava sob o predomínio do pensamento imediato para lidar com as adversidades ambientais, como a ameaça de predadores e a conquista do alimentação. Assim, começa uma história de centralidade, onde o corpo ameCultura Europeia e do Mediterrâneo na Universidade da Basilicata, Itália. Atualmente, dirige o Cognitive Science Studies for the Research Group, na Duke University.
} 
${ }^{4}$ Processo de desenvolvimento do córtex cerebral, a camada responsável pela integração do processamento das representações simbólicas, da razão, linguagem, percepção, emoção, cognição e memória.

https://pt.wikipedia.org/wiki/C\%C3\%B3rtex_ce-

rebral açado age para se defender de um dano percebido como proveniente do lado externo. Um descolamento do ambiente que por milhares de anos permitiu ao homem sobreviver de modo razoável e, por tantos outros, evoluir para novos modos de se perceber e de reconhecer o mundo.

De sua noção de centralidade em relação ao ambiente, emergiram novos comportamentos e modos de ocupar espaços no mundo, tanto em grupo quanto individualmente. Um salto no processo de evolução decorrente de uma "rápida corticalização do cérebro"4, diz Maldonato, que promoveu uma "formidável afinação das funções cognitivas" de onde emergiram "comportamentos sofisticados, flexibilidade adaptativa, formas de pensamento cada vez mais complexos e um poderoso desejo de descoberta" (MALDONATO 2017, p. 29). Um processo de desenvolvimento que tempos depois se transformaria em uma racionalidade que se organizava e caminhava em busca de explicações e respostas para o desconhecido.

Após um longo processo de evolução e adaptação entre o homem e o ambiente com seus subsistemas, uma série de emergências ocorreram: as pessoas se organizaram em grupos maiores; criaram regras de convívio; desenvolveram técnicas de construção de abrigos, de agricultura e de produção de objetos; criaram sociedades; passaram de uma cultura de aquisição do conhecimento por via oral para a da escrita e da leitura. Tudo é apenas um reduzido relato da milenar e complexa história da humanidade, como abertura para se abordar um de seus maiores feitos: o desenvolvimento da ciência, fato que transformaria o modo de pensar e agir sobre o mundo em um processo sistematizado de observação e validação.

Esses procedimentos viriam a caracterizar o paradigma científico clássico que emergiu devido em parte a busca de respostas comprováveis, construídas a partir de um mé- 
todo de obtenção passível de ser replicado e em parte ao descontentamento com o tipo de raciocínio e de interpretação dos fenômenos na cultura pré-moderna, baseados em uma visão construída a partir das lentes da religião, da monarquia e da filosofia em volta desses grupos de poder.

O método cartesiano (1596-1650), se tornou um ponto de ruptura com a prática anterior. Em sua obra "Discurso do Método" (1637), o filósofo René Decartes fundamenta o que se transformaria no método científico moderno, cuja característica principal é a racionalidade na busca do conhecimento, manifestada por uma abordagem analítica que impõe que toda verdade necessita de evidências. Seu processo de observação pressupõe que o todo pode ser compreendido pela apreensão de suas partes. A dúvida é o seu elemento principal e para respondê-la torna-se necessário um processo analítico indutivo, que considera a necessidade de dividir o todo em partes menores e que essas partes sejam capazes de explicar o todo. Esta abordagem, predominante até o início do século XX, considerava o mundo como uma máquina, passível de ser dominado por seu observador.

Um emblema do predomínio desse modelo de pensamento de dominação da natureza pode ser exemplificado de modo direto pelos jardins do castelo de Versalles, iniciado em 1661 a cargo do paisagista francês André Le Nôtre. Considerado como uma obra de arte, seu projeto se propunha a organizar a natureza a partir da adoção de princípios da simetria, uma forma de sobrepor a ordem sobre o que era considerado desordem, a cultura sobre a natureza.

A contribuição de Descartes para a ciência é inestimável, desde ter rompido com um modelo de construção de conhecimento dominado por grupos minoritários, mas poderosos, até ter embasado, por seu método de raciocínio, o modelo de pensamento científico posterior, sintetizado por Isaac Newton (16431727) a partir de influências de cientistas e filósofos.

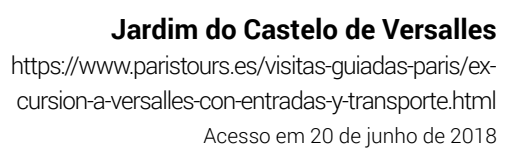

Acesso em 20 de junho de 2018 

Desde seu surgimento, esse paradigma é considerado imprescindível para a investigação científica. Porém já não é mais suficiente apreender o mundo através da perspectiva mecanicista de Descartes, que o concebia tal qual uma máquina, como um mecanismo fechado às influências externas e, portanto, passível de ser submetido ao domínio da ciência clássica.

No início do século $\mathrm{XX}$, a partir de um pensamento fundamentado na biologia, cujo entendimento da vida se baseia na ideia de um organismo integrado, surge uma nova onda de pensamento científico em oposição à concepção cartesiana. Segundo estes pensadores, a análise não dá mais conta do entendimento científico que, a partir de então, necessita de um olhar que se volte para sistemas, entendendo que o todo é maior do que a soma das partes. Essa premissa é discutida exaustivamente por Edgar Morin em várias de suas obras. Em Ciência com Consciência, ele recorre ao dito por Pascal de que "só posso compreender um todo se conheço, especificamente, as partes, mas só posso compreender as partes se conhecer o todo", para afirmar o abandono de explicações lineares em troca de explicações em movimento e circulares que seguem do todo para as partes e das partes para o todo (1996, p. 182).

O surgimento da cibernética e da teoria dos sistemas reitera esse pensamento relacional ao declarar que "ao mesmo tempo, um sistema é mais e menos do que aquilo que poderíamos chamar de soma de suas partes. (...) menos porque essa organização provoca coações que inibem as potencialidades existentes em cada parte, isso acontecendo em todas as organizações, inclusive as sociais...". e mais "porque faz surgir qualidades que não existiriam nessa organização; essas qualidades são 'emergentes' (...) essas qualidades emergentes retroagem ao nível das partes e podem estimulá-las a exprimir suas potencialidades." (MORIN, 1996, p. 180). 
Esta percepção de fundamentação organicista, denominada de abordagem sistêmica, inverte o modo de se observar e conceber o mundo e seus fenômenos. Por ela, as propriedades das partes são somente compreendidas por meio de como se organizam e agem no todo. Neste sentido, a visão empreendida pela ciência clássica, entendida como reducionista, começa a perder espaço para uma perspectiva mais abrangente, mais geral de observação, que faz uso de conceitos como organização, conexão, relação, contexto e padrão.

A teoria dos sistemas surge com uma proposta de observação baseada no estudo de totalidades, em que devem ser considerados a estrutura do fenômeno, as relações entre as partes, sua capacidade para auto-organização, sua não linearidade, seus processos de adaptação e a possibilidade de emergências. Essas são qualidades sistêmicas não identificadas em observações analíticas. Se o paradigma científico clássico era analítico, o sistêmico partia da ideia de síntese, em busca de compreender os fenômenos em sua totalidade e em relação às condições dadas pelos contextos nos quais estão postos. Para os pensadores sistêmicos, a manifestação de fenômenos complexos acontece em decorrência de suas trocas com o ambiente e de como isso acontece. Assim, buscam ao invés de dividir e isolar, reconstruir e relacionar.

Uma ciência capaz de interligar e contextualizar se torna cada vez mais necessária para lidar com a vida e sua crescente complexidade. Desse modo, o novo paradigma surge em meio a proeminência de desafios cujos caminhos tradicionais de investigação eram ineficientes. Esses novos desafios demandam por novas abordagens que sejam generalistas e interdisciplinares de modo a permitir entender e enfrentar problemas sistêmicos.

Segundo von Bertalanffy (1968), este novo paradigma científico surgiu para abranger "novos problemas, espe- 
cialmente os que anteriormente eram rejeitados, como os "metafísicos", aqueles que transcendem ao que é tangível (p. 38 e 39). Afirmava ele, que "agora aprendemos que para uma compreensão não bastam apenas os elementos, mas são necessárias suas inter-relações" (p.14).

A percepção sobre interligações é, portanto, algo que se impõe como imprescindível ao entendimento dos novos problemas, que cada vez mais emergem de arranjos diversos. A queda de uma parede de gelo não pode ser vista como uma simples ocorrência da natureza, mas como um fenômeno decorrente de uma variável de possibilidades a se desdobrar em danos com efeito global. Essa representação ilustra também o pensamento do sociólogo Derrick de Kerckhove (1997) sobre os desafios com os quais a humanidade precisa se capacitar para lidar. Kerckove afirma que a sociedade atual necessita de pessoas que saibam "intuir o que é preciso ou não, num cada vez mais complexo conjunto de ambientes integrados, auto ajustáveis, de possibilidades" (1997, p.109). Essas pessoas devem estar aptas a coordenar ações em contextos de crise, dos quais emergem fenômenos que rompem com a ordem e solicitam novos olhares, processos e posicionamentos face aos desafios que trazem consigo. Para Morin (Fronteiras do Pensamento, 2013), crises são situações das quais emergem resultados tanto melhores, quanto piores em relação ao estado anterior.

Dentre essa miríade de desafios, o que se percebe é que estes são cada vez mais oriundos de entrelaçamentos de origens e fatores diversos, o que os tornam um problema mal definido, sistêmico, complexo e, supostamente, de solução impossível. Uma classe de problemas defini-

${ }^{5}$ Wicked Problems Termo cunhado pelos designers, ambos pesquisadores e professores da Universidade da Califórnia em Berkeley, em artigo publicado no ano de 1973 pela revista Policy Sciences sob o título de Dilemmas in a General Theory of Planning. da por Horst Rittel e Melvin M. Webber, como a dos "wricked problems" 5 em uma tradução livre podemos considerá-lo como problemas capciosos ou intrincados, no sentido de escorregadios, e dificéis de lidar. Em geral eles resistem 
6 "Wicked problems are difficult to formulate/frame, exist atmultiple levels of scale, there is no clear stopping point and every wicked problem can be considered a symptom of anotherlarger wicked problem. (Irwin 2012) Tradução Livre

${ }^{7}$ Terry Irwin Designer e diretora da escola de design da Universidade Carnegie Mellon. É umas das fundadoras do programa de pós-graduação em Design Trasition, da instituição. a abordagens que se valem de instrumentos de investigação tradicional conduzidos por um pensamento não relacional.

Esses problemas são sempre abrangentes e estão conectados com questões sociais e ambientais. Escassez de alimentos, de água, de empregos, precarização na educação e na saúde, conflitos transnacionais, econômicos, políticos e sociais, são algumas de suas manifestações. Sobre, a partir e sob cada um destes surgem outros, tornando difícil estabelecer um fluxo de causa e consequência claro e de fácil entendimento. Problemas desse tipo, "são difíceis de formular/enquadrar, existem em múltiplos níveis de escala, não há um ponto de parada claro e todo problema perverso pode ser considerado um sintoma de outro problema perverso ainda maior."' (IRWIN 2012, p.3) ${ }^{7}$.

Neste sentido, qualquer desafio que apresente uma organização baseada em relações de interdependência é passível de ser abordado de modo sistêmico, o que se $\neg$ constata pela afirmação de von Bertalanffy que diz que "o paralelismo de concepções gerais ou, até mesmo de leis especiais em diferentes campos é uma consequência do fato de que estas se referem a sistemas" as quais segundo ele, podem ser aplicadas "a sistemas independentemente de sua natureza" (Apud CAPRA, 2006 , p.55). A compreensão de todo sistema complexo tem origem na noção de sistema aberto, isto porque seu equilíbrio se dá, entre outras operações, por sua relação com outros sistemas. São processos nos quais uma série de manifestações ocorrem a partir do que a estrutura de cada sistema permite ou não acontecer, as quais são explicitadas por conceitos, princípios e padrões que ajudam a tecer a visão geral do que se entende por complexidade. Esses elementos constituem um arcabouço de fundamentação ao pensamento sistêmico imprescindível para o que aqui se denomina por definição-trama. 
E neste sentido, sua definição também o é, porque recorre a uma trama de outras definições para se fazer compreendida.

Pensar sobre, e com, problemas complexos, exige que se altere a imagem o quadro 1 - no qual Bar-Yam ${ }^{8}$ apresenta conceitualmente o espaço de investigação baseado no paradigma científico tradicional - onde as disciplinas, à medida em que se aprofundam no estudo, se

\section{${ }^{8}$ Yaneer Bar-Yam}

Formado em física pelo MIT I Instituto de Tecnologia de Massachusetts, é cienttista sistêmico e atualmente presidente do New England Complex Systems Institute e autor dos livros: Dynamics of Complex Systems (1997) e Making Things Work: Solving Complex Problems in a Complex World (2005).

\section{Sistema Simples}

Quadro 1

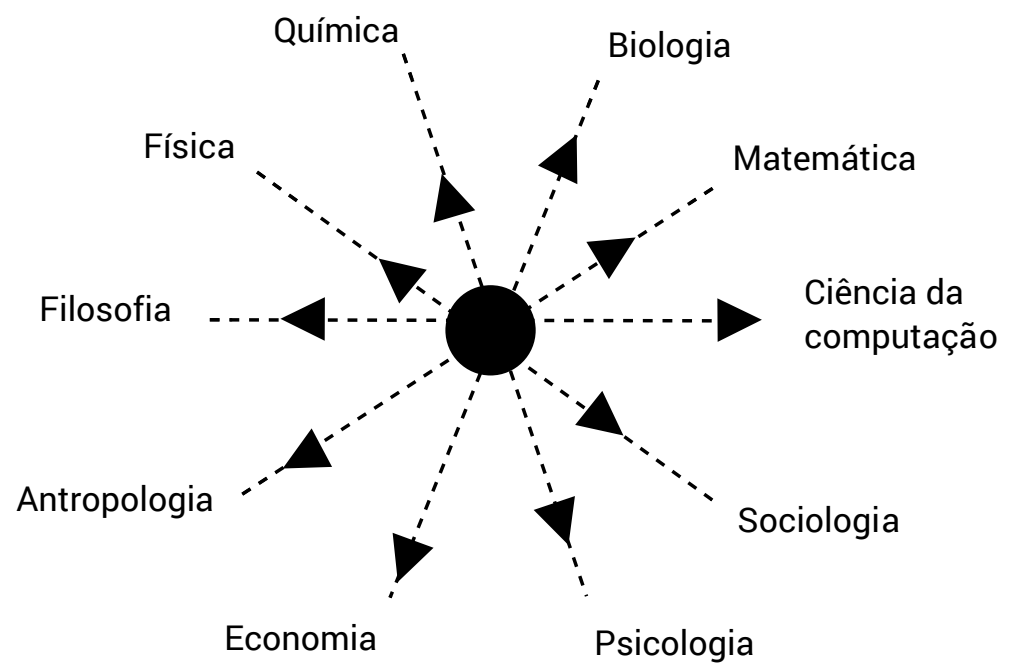

\section{Sistema Complexo}

Quadro 2

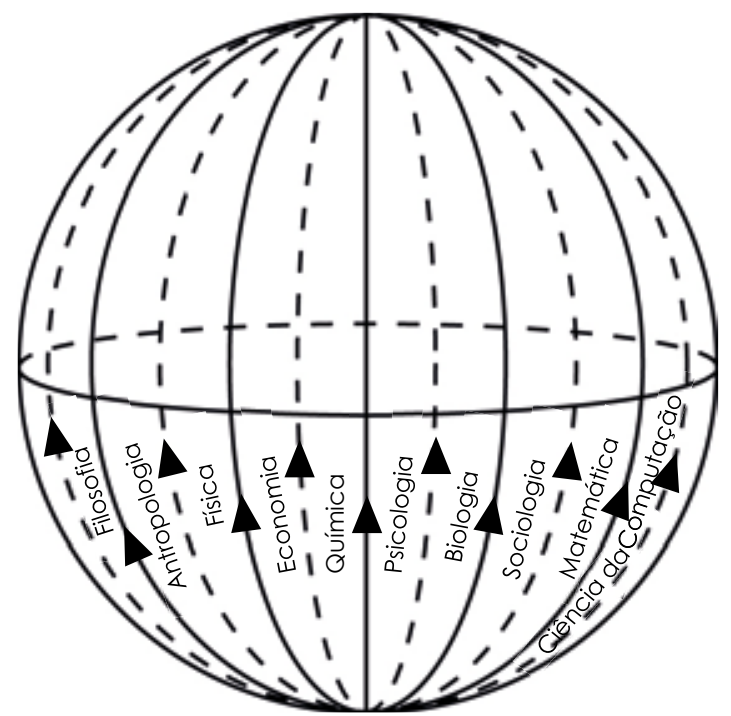

distanciam umas das outras em decorrência de direcionar o seu foco para as suas especificidades, obtendo uma quantidade maior de detalhes, porém de modo isolado. No quadro 2, se percebe uma visão sistêmica, que abor-
Gráficos redesenhados e complementados do livro Dynamics of Complex Systems (1997), de Yaneer Bar-Yam. 

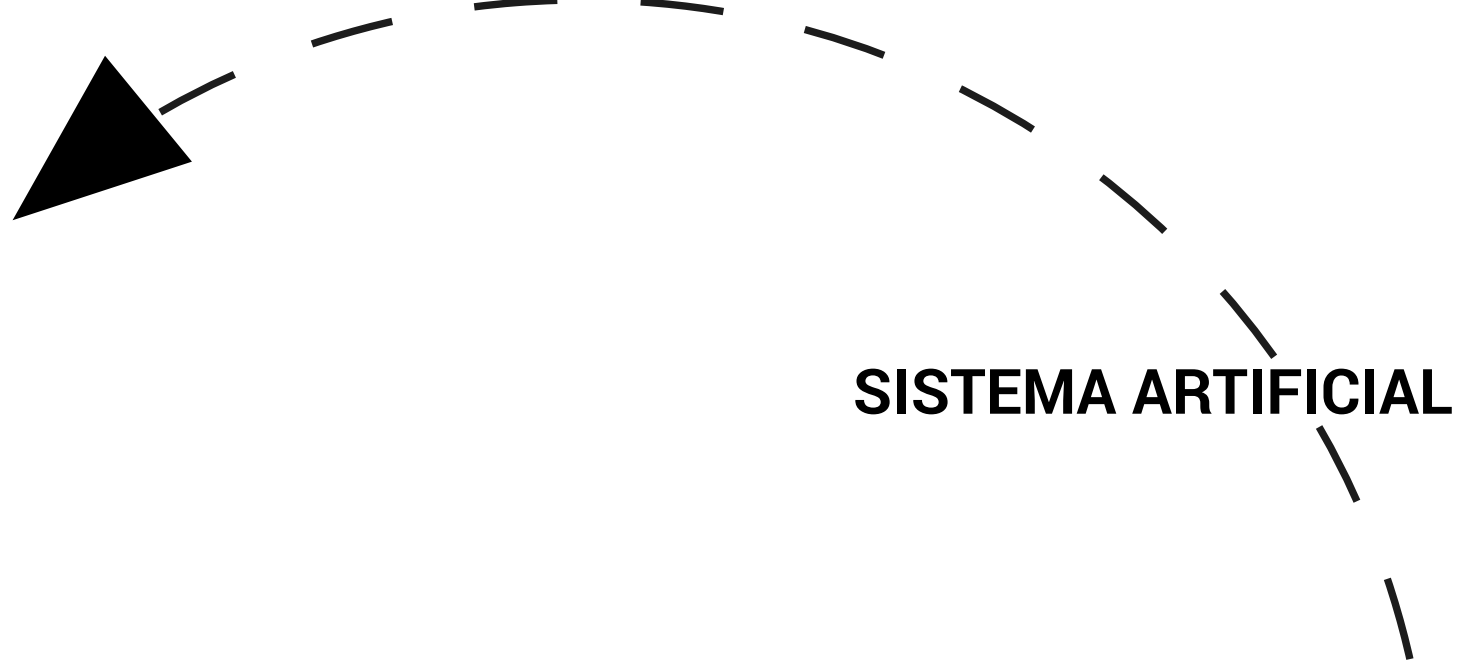

1
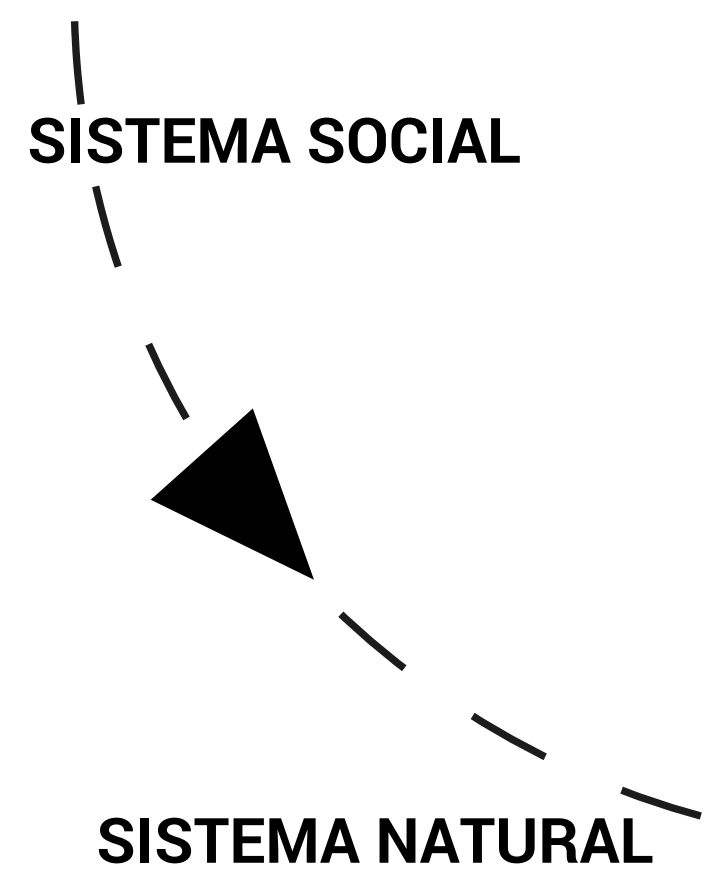

A organização da vida humana no mundo por três sistemas interdependentes: sistema natural, social e construído.

Imagem 4, 5 e 6 (pg. 43)

Photo by Fré Sonneveld on Unsplash Photo by Gades Photography on Unsplash Photo by David Sola on Unsplash Acesso em 18 de junho de 2018

Entre a diversidade de sistemas que estão sob o guarda chuva da complexidade, é possível percebê-los a partir de três classes: 1) a de ordem natural - plantas, pessoas, animais etc., 2) social, que se configura pelo modo como se organizam as pessoas e animais, 3) os sociais em grupos e 4) os sistemas construídos, como leis, culturas, cidades, empresas, escolas etc., muitos dos quais baseados nas dinâmicas e qualidades sistêmicas dos dois primeiros. 


$$
\text { - }
$$




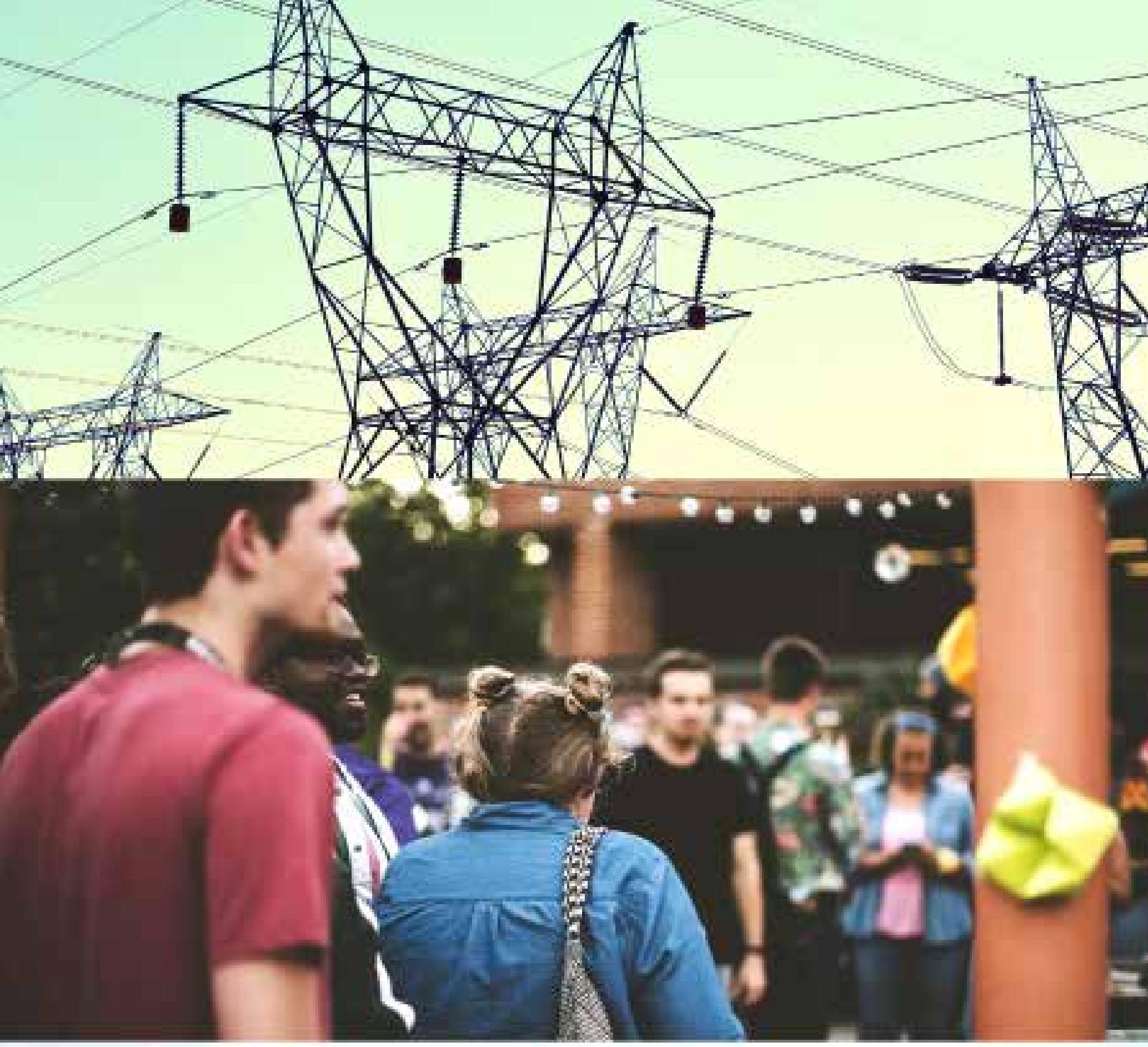


da as propriedades de modo ampliado e interligado. Há um movimento sinérgico das disciplinas sobre o problema, fazendo com que dessa relação surja um todo mais diverso, profundo e abrangente, com maiores possibilidades de respostas integradas.

De modo geral, sistemas são definidos seguindo a caracterização elaborada pelo biólogo von Bertalanffy, um dos pioneiros da teoria geral de sistemas - T.G.S. (19671968), como um "conjunto de componentes em estado de interação" (1968, p. 63). Ele usa como sinônimo os termos de totalidade e organização. No entanto, Edgar Morin observa que a palavra totalidade "evoca algo completo em si mesmo, num sentido absoluto, fechado" (Apud PENA-VEGA e ALMEIDA, 1999, p.103). Em substituição, o sociólogo francês traz o termo globalidade que, de acordo com ele, indica não só a existência de uma abertura como uma ação relacional, uma definição mais alinhada com a de sistemas complexos, que se manifestam a partir de diversas relações.

Um ponto inicial no estudo de sistemas é distingui-lo daquilo que não é sistema. Não são sistemas os amontoados de coisas sem relação. Para a epistemóloga Maria Vasconcellos (2013) são as relações que dão "coesão ao sistema todo, conferindo-lhe um caráter de globalidade" (2013, p.199). Os sistemas podem ser simples e complexos. Essa distinção está baseada no modo como estão organizados, no que se refere a quantidade e diversidade de elementos que se mobilizam para a realização de um propósito comum maior, e também a como essa dinâmica ocorre em relação ao ambiente.

Quando complexos, sistemas podem ser qualificados também como de baixa, média e alta complexidade, e sobre essa indicação, Yaneer Bar-Yam (1997) diz que esse grau pode ser mensurado tomando como referência a quantidade de informação utilizada para descrevê-lo. Para ele, a complexidade de sistemas é uma medida matemática. Além dessa 
concepção, há também a que considera que a complexidade de um sistema se refere ao grau de liberdade que seus elementos têm para interagir com outros, com quantos elementos podem se relacionar e, a depender dessa quantidade, pode ser considerado complexo, mesmo que não tenha um número considerável de elementos.

Em sistemas sociais, ambas as definições permitem perceber de que modo a complexidade pode se manifestar em determinados contextos, como em um grupo familiar, que em geral é um sistema composto por poucos elementos, mas de alta complexidade. Seus elementos são sistemas complexos e estabelecem relação com todos do sistema, influenciando e sendo influenciados, com força para gerar situações de todos os tipos - conflituosas, de disputa, de solidariedade, enfim com graus diversos de relacionamentos.

Uma empresa, com muitos funcionários, com uma diversidade de papéis distribuídos de modo isolado, compartimentalizado e com baixa interação em termos de relação social, tende a ser um sistema menos complexo que o do núcleo familiar. A concepção de um sistema como simples ou complexo deve considerar não somente os aspectos visíveis, mas também os não percebidos de imediato e que se manifestam no decorrer de um determinado tempo. $\mathrm{O}$ reconhecimento dessa distinção coloca ao observador que a complexidade está antes de tudo condicionada ao potencial que a estrutura do sistema permite - como o sistema se conforma - a ocorrência das relações entre seus elementos, e consequentemente, do que pode delas emergir.

Ao se estudar um sistema, são observadas características denominadas por von Bertalanffy (1968) de isomórficas, aquelas que são comuns a todos, seja de qual domínio forem. Assim, é possível que se determine um sistema pela identificação de suas características observáveis. Estes aspectos permitem que sistemas sejam abstraídos em 
suas qualidades fundamentais e descritos de modo mais abrangente por meio de um conjunto de padrões.

Uma característica importante dos sistemas é que podem ser qualificados quanto a sua constituição, podendo ser físicos/concretos, como uma bicicleta ou uma casa, ou conceituais/abstratos, como um conjunto de leis, teorias ou ideias. Estas características que os separam não trazem a impossibilidade de que os dois tipos se manifestem em um único sistema, haja visto os computadores que possuem tanto uma organização física, seu hardware, quanto abstrata, seu sistema operacional, sua parte abstrata. O mesmo pode ser dito sobre corpo humano que é concreto, por sua materialidade/natureza, e abstrato quando manifesta pensamentos, ideias e sentimentos. Tudo isso está relacionado e é indissociável.

Com relação ao seu comportamento, sistemas podem ser considerados como dinâmicos ou estáticos. Estas características podem ser observáveis no estudo de vários tipos de fenômenos como os sociais, biológicos, organizacionais, econômicos etc., que, em geral, são caracterizados predominantemente como dinâmicos e estão sujeitos a alterações constantes, por variarem ao longo do tempo em decorrência do comportamento de seus elementos. A partir de trocas frequentes eles se mantêm em equilíbrio e quando não mais as realizam, tendem a morrer ou se transformam em outros tipos de organizações. É possível identificar essa transformação em processos de aculturação quando, pela ausência ou enfraquecimento de reforços, determinadas culturas acabam por se descaracterizar e se afastar de suas tradições. São também dinâmicos o sistema de trânsito, de educação, de bolsas de valores, a sociedade, o copo humano, a política, entre outros.

Os sistemas estáticos são, por sua vez, aqueles cuja propriedades não são alteradas significativamente ao longo do tempo. Uma observação fundamental no estudo de 


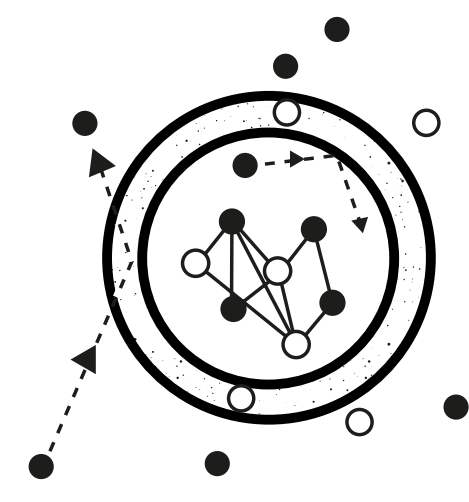

SISTEMA ISOLADO

Matéria $O$ Energia

Fonte: Elaborado pela autora com base em Dynamics of Complex Systems Bar-Yam

(1997) sistemas é a sua relação com seu ambiente. Todo sistema está referenciado a um, mesmo que não mantenham qualquer tipo de troca com ele. Esta é a característica que determinará se é isolado, fechado ou aberto.

Sistemas isolados: são aqueles que não realizam trocas como com o meio externo. Ocorre que estes sistemas possuem um tipo de fronteira que bloqueia a troca, tanto de matéria quanto de energia. Um exemplo recorrentemente utilizado para expor esse modelo é o de uma garrafa térmica que possui duas fronteiras de contenção de energia, entre as quais existe um vácuo, um espaço onde ocorre a neutralização da troca. Este é o motivo do conteúdo interno se manter por muito mais tempo aquecido ou gelado. No entanto, há de se considerar que o comportamento perfeito de um sistema isolado se restringe ao conceito. Mesmo que muito reduzida, a troca de energia entre ele e meio acontece, isso explica porque o líquido quente ou frio de um recipiente térmico, mesmo que após um período maior, entre em equilíbrio com a temperatura externa.

Em contextos sociais, é possível que este modelo ocorra de modo semelhante. Um exemplo no qual pode-se aplicar essa dinâmica é o da cultura Amish, comunidade de cristãos radicais surgida na reforma protestante do século 16, que busca viver em isolamento, como medida para evitar o contato com os não puros, pessoas das sociedades contemporâneas - industrial e tecnológica - e correrem o risco de terem sua crença e modo de vida corrompidos. Eles vivem prioritariamente em alguns estados dos EUA e do Canadá e seus hábitos resistem, sem consideráveis transformações há quase quatro séculos, graças não só ao isolamento cultural, mas também ao distanciamento geográfico das cidades, o que minimiza as possibilidades de contato. 

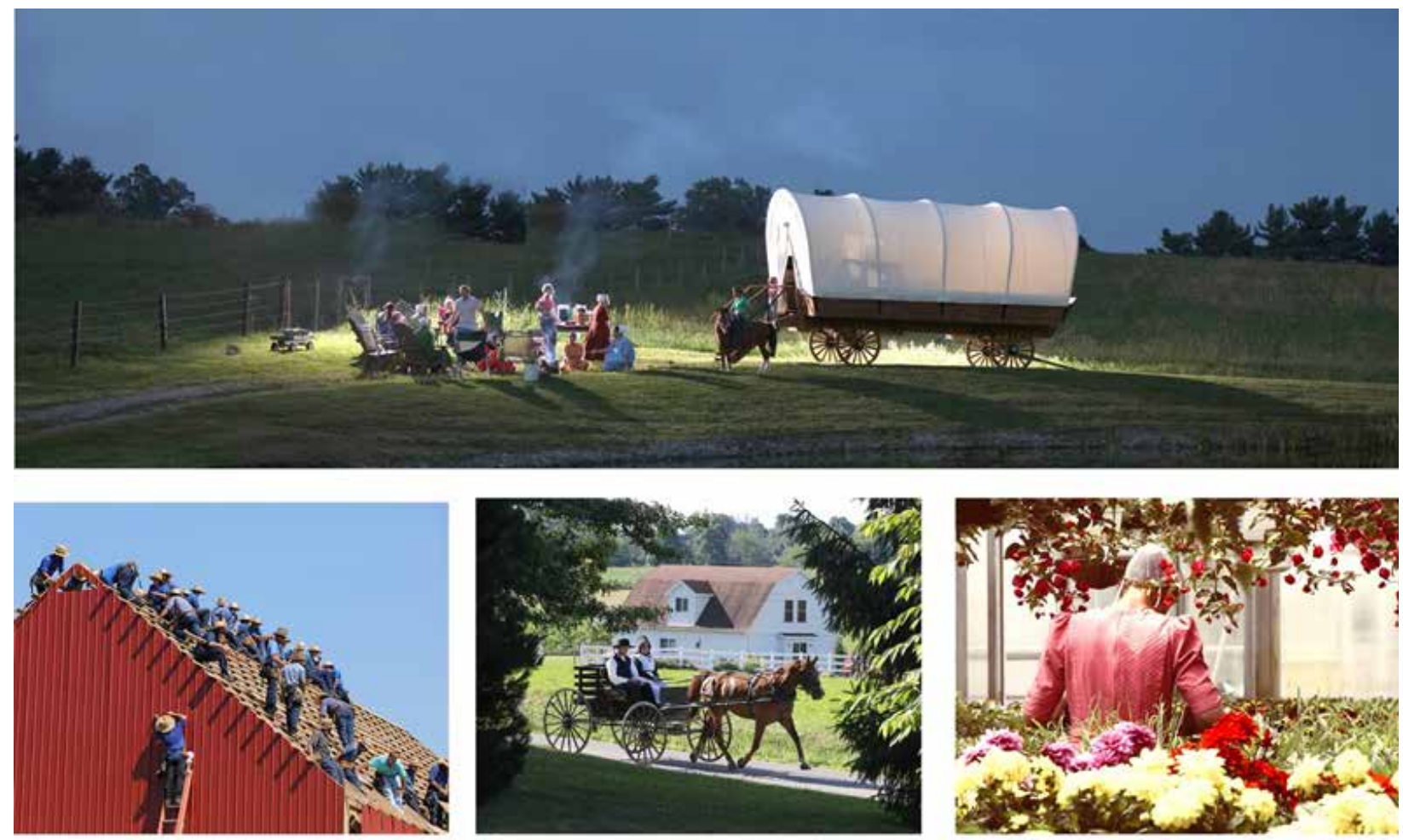

Sistemas fechados: são denominados também de herméticos, porque são vedados e não realizam intercâmbio de matéria com o ambiente externo, havendo apenas a possibilidade de troca de energia entre ambos. Sobre eles não há influência externa capaz de alterar sua dinâmica interior, que se mantém sob o domínio de operações programadas. A energia que entra no sistema retorna ao meio em forma de energia, não há em sua descrição a possibilidade de que seu processamento e consequente produto de saída aconteça de modo inesperado. Uma linha de produção de uma fábrica produzirá o produto esperado como resultado de seu processo, porque é fechada a influências externas. Do mesmo modo é possível que aconteça com uma organização, com um sistema político, biológico e social.

Dois campos de pesquisa importantes que adotaram o conceito de sistema fechado como chave para suas argumentações foram os da biologia a partir de Humberto Maturana e Francisco Varella (1974) e posteriormente, o sociológico com Niklas Luhmann (1995).

\section{Imagens do cotidiano Amish}

http://www.conteudoseducar.com.br/ conteudos/arquivos/2752.pdf

Acessado em 17 de novembro de 2018

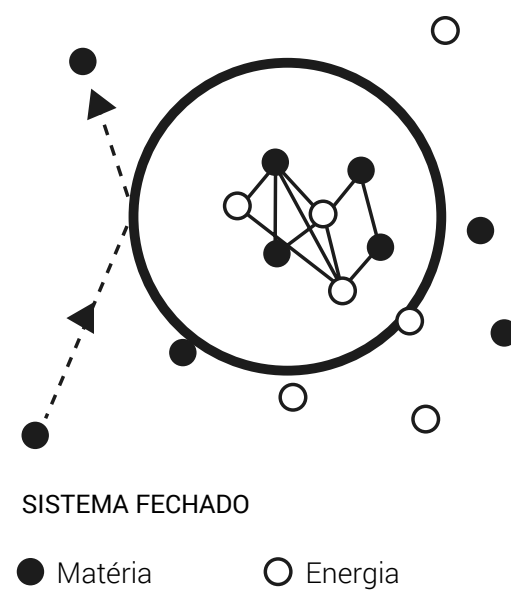

Fonte: Elaborado pela autora com base em Dynamics of Complex Systems Bar-Yam (1997) 
O conceito de autopoiese elaborado pelos biólogos na década de 1970 trata da capacidade que seres vivos possuem de produção de si mesmos. Eles afirmam que neste sentido são sistemas fechados, porque não podem ser influenciados pelo meio. A afirmação de Maturana e Varela (1974) colocou em questão o pensamento da ciência que considera os seres vivos como sistemas biológicos que trocam informações com o meio. Para ambos, um sistema para ser considerado vivo necessita produzir-se a si mesmo, a partir de suas auto referências. Nesta concepção de organização, há nitidamente uma base mecanicista, não aquela que divide em partes, mas sim a que concebe o todo a partir de um processo de retroalimentação, via operações de comunicação, como são definidas as máquinas cibernéticas.

Ainda sob uma base cibernética, os pais da autopoiese exemplificam esse modo de operação fechado, por um processo cognitivo, dizendo que, escutar alguém não é

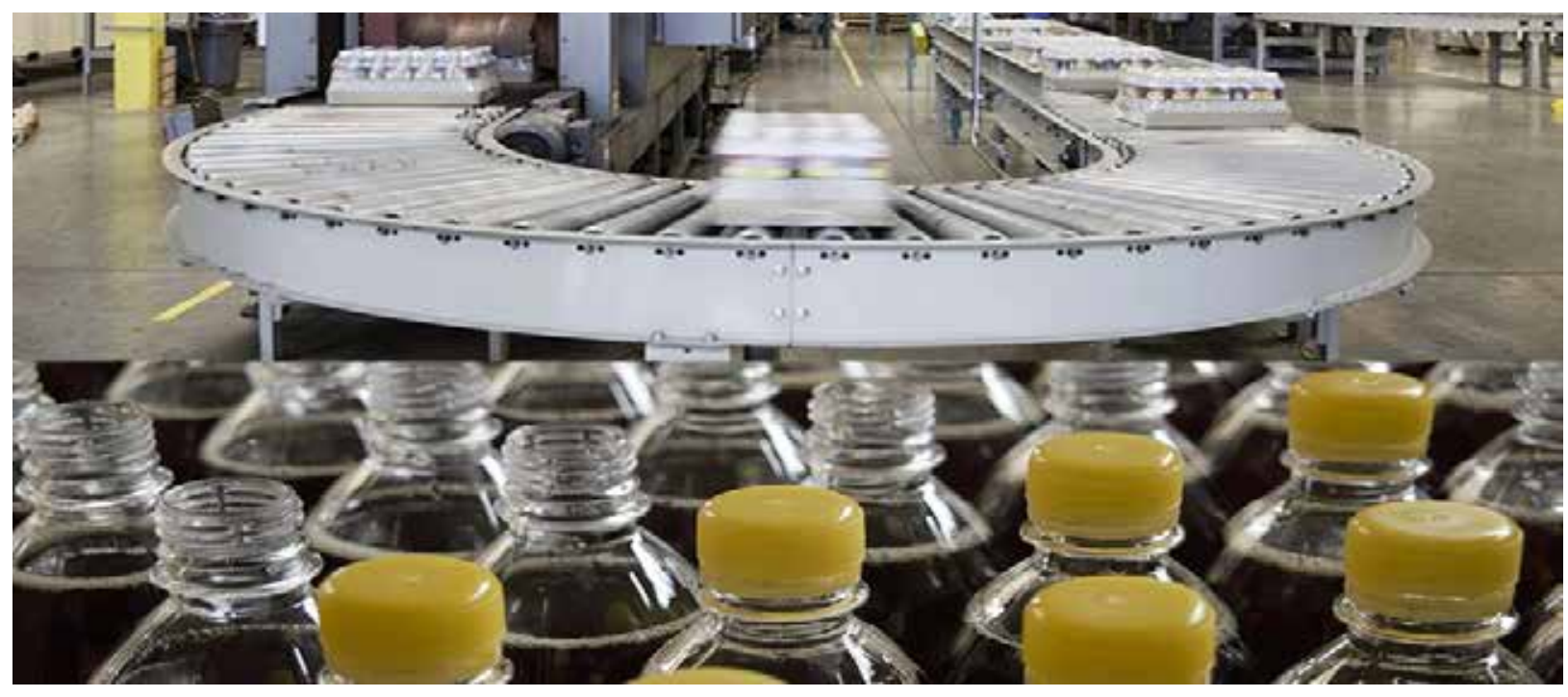

Envasamento de bebidas https://www.weg.net/institutional/BR/pt/ news/corporativo/seminario-online-solucoes-de-eficiencia-energetica-para-o-segmento-de-alimentos-e-bebidas algo que vem da capacidade do outro em promover transformações em nosso sistema cognitivo, mas de algo que está dentro do próprio sistema, que realizará, por meio de sua própria estrutura as transformações. Eles complementam explicando que essa transformação é possível que ocorra, mas somente após "um período suficientemente 
longo para nos tornarmos estruturalmente congruentes, resultando em sermos capazes de compreender o outro" (MATURANA e VARELA, 2001, p. 174), sendo este um resultado do seu processo de evolução, que decorre da retroalimentação que realiza.

Esse estado de compreensão mútua entre os envolvidos, pode ser pensado pela perspectiva de que um agente externo afinal acabou por alterar o sistema inicialmente fechado. O que permite inferir que a partir de um determinado momento houve uma espécie de retroalimentação, quando os sistemas passam a trocar entre si. Quando se trata de pensar a influência do meio sobre o sistema, o axioma que o descreve é denominado de encerramento operativo, que trata de especificar sob quais condições é possível que tal influência ocorra e quais estímulos irão de algum modo afetar o sistema.

Luhmann, referindo-se a este conceito, diz que "o meio só pode influir causalmente em um sistema no plano da destruição, e não no sentido da determinação de seus estados internos" (1995, p. 130). Por se tratarem de sistemas determinados estruturalmente, seguirão empreendendo ações em função do que objetivam realizar. Para Luhmann (1995), o encerramento operacional é um aspecto significativo dos sistemas sociais, porque é por ele que as diferenças entre o sistema e o entorno serão mediadas. Segundo o sociólogo, "sistemas sociais operam [...] fechados sobre sua própria base operativa, diferenciando-se de todo o resto e, portanto, criando seu próprio limite de operação". Neste sentido, "o fechamento é a condição da abertura do sistema ao ambiente: o sistema só é capaz de estar atento e responder à causalidade externa por meio das operações que ele próprio desenvolveu" (1995, p. 79).

O conceito de sistema fechado ocupa, tanto para Luhmann, quanto para Maturana e Varela, um aspecto 


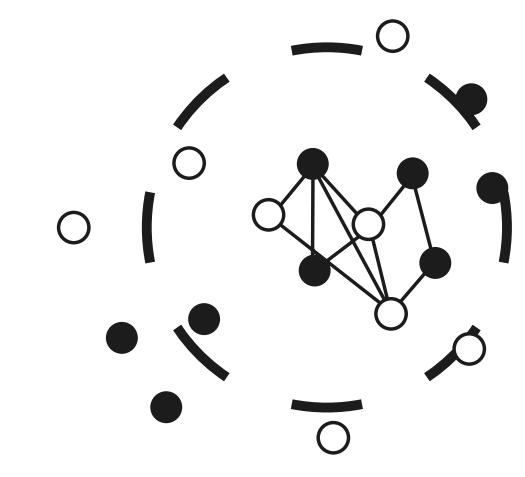

SISTEMA ABERTO

Matéria

Energia

Fonte: Elaborado pela autora com base em Dynamics of Complex Systems Bar-Yam (1997) central em processos de auto-organização de sistemas que se referenciam a si mesmos para se autocriarem. Este tipo de operação pode acontecer dentro de alguns processos de um sistema, não necessariamente se refere a operação dele como um todo.

Sistemas abertos: são aqueles que realizam trocas com o ambiente e sua existência se sustenta por essa relação. Assim sendo, a priori, não dependem unicamente de sua organização interna como os isolados e fechados, mas também de sua capacidade de interação com o que o envolve. Esta é uma de suas principais distinções em relação aos demais tipos. Sistemas abertos caracterizam os fenômenos denominados complexos, que emergem de condições de trocas e influências entre sistema e ambiente, como aqueles relacionados a cultura, ao conhecimento, a epidemias, aos desastres naturais etc.

Iniciando pela ideia de sistema a partir de uma percepção contextual, sistemas são organizações que, de um modo ou de outro, estarão sempre referenciadas a um ambiente, mesmo que com ele não estabeleçam qualquer relação. Neste sentido, não existe a possibilidade de compreendê-los sem que se conheça seu ambiente, suas relações e principalmente as influências mútuas.

Em outro nível de relação, sistemas podem ser sistema em um determinado contexto e elemento em outro. Este sistema complexo é constituído essencialmente por uma estrutura baseada em relações que tornam seus subsistemas mutuamente interdependentes, fazendo com que uma mudança em um deles provoque, ou tenha o potencial de provocar, irritações em outros.

Esta percepção de globalidade considera ultrapassado o pensamento que concebe um problema complexo observando-o do limite de sua fronteira para dentro. A compreensão de sistemas abertos pressupõe que há um contexto, um todo que é maior, que influi sobre o que ocorre com o sistema e vice versa. 
Conceber que sistemas existem dentro de um ambiente, significa também admitir que entre ambos há uma fronteira, que estabelece o que é um e o que é outro. Segundo Maria Vasconcelos, essas fronteiras "não são sistematicamente concebidas como barreiras, mas sim como lugar de relação" (2013, p.207), no qual há condições postas como filtros para o que se pode trocar ou não.

Sistemas abertos possuem padrões de comportamento básicos, que podem variar em quantidade, intensidade, frequência e outros aspectos. Porém em geral possuem:

(1) Entrada (input): conteúdos provenientes do ambiente externo, insumos em forma de energia, matéria ou informação.

(2) Processo: operações que ocorrem no interior do sistema e que podem descrevê-lo a partir do modo como essas atividades ocorrem.

(3) Saída (output): é o resultado das operações de um sistema, que deve ser coerente com aquilo para o qual se propôs. Quando em condição de subsistema, seus resultados são intermediários, porque serão inputs para o sistema ambiente.

(4) Retroalimentação (feedback): retornos informacionais, que são comparados com critérios preestabelecidos. Os retornos podem ser positivos, quando correspondem ao esperado ou negativos quando divergem dos critérios neces-

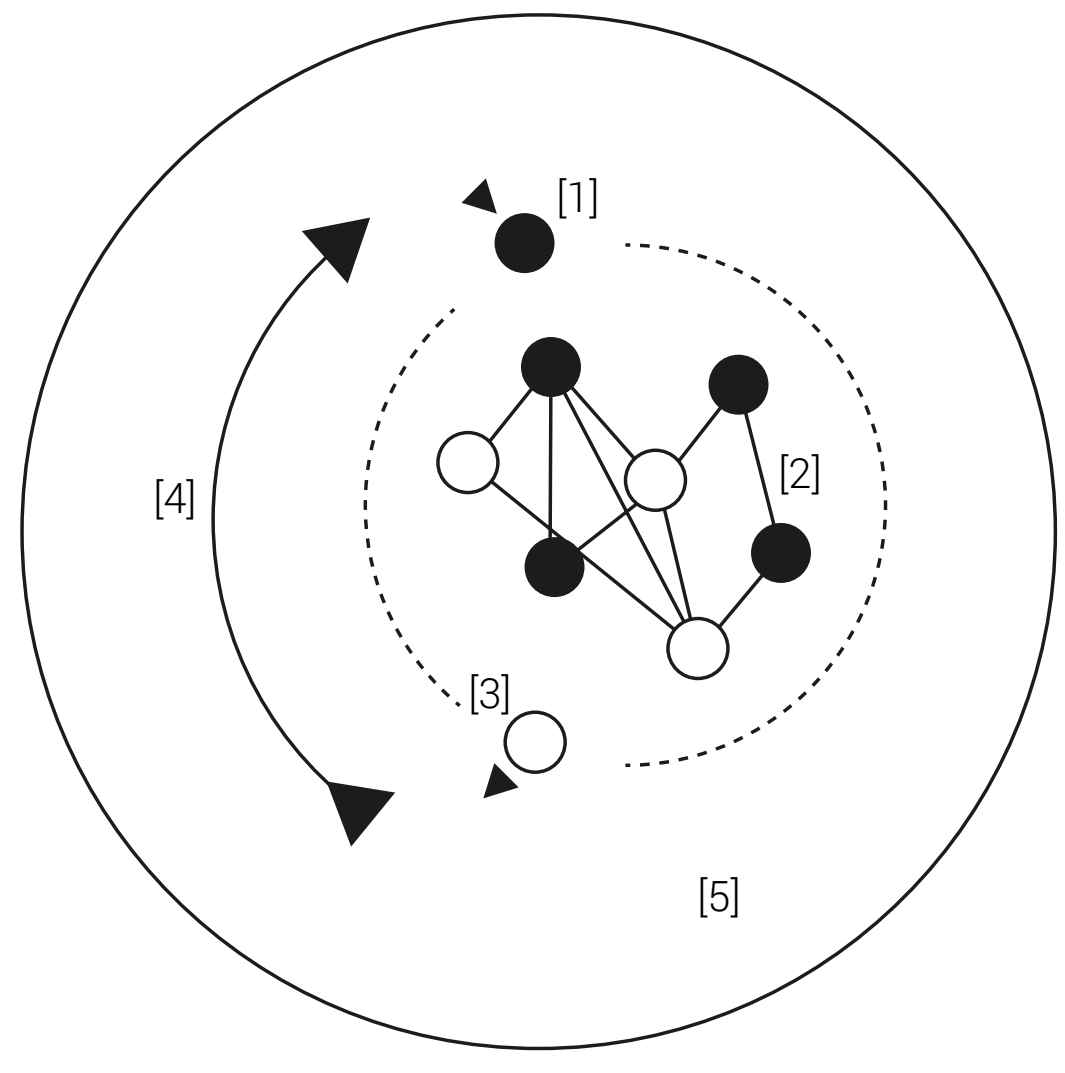
Fonte: Elaborado pela autora sários para a manutenção do 
equilíbrio do sistema. O processo de retroação permite que o sistema perceba a necessidade de ajustes para manter-se em operação.

(5) Ambiente: é o contexto do sistema, é onde ele existe. Como o lugar do sistema, há de ser considerado pela dimensão da relação que estabelece com ele. É possível que um ambiente tenha vários sistemas em interação, denominadas de relações intersistêmicas.

O estudo de sistemas abertos demanda por métodos que unam sistema e meio. Morin (1996) chama a atenção para o fato de que isolá-los seria "criar in vitro um isolamento puramente determinista, mas esse determinismo puro exclui a realidade ambiente" (pg. 202), em outras palavras, o estudo apresentaria resultados alheios às ocorrências de estímulos e às suas origens. Este estudo seria de uma parcialidade comprometedora, sem consistência para relatar a complexa realidade do todo. 


\section{2 \\ CIBERNÉTICA E SOCIEDADE}

O surgimento da cibernética, liderado pelo matemático Nobert Wiener, foi uma das maiores contribuições à concepção de sistemas vivos. Porque diferentemente da busca dos teóricos sistêmicos, que se debruçavam sobre a organização de sistemas, os ciberneticistas olhavam para outra direção e tomavam o caminho para entender de que modo a inteligência desses sistemas controlava suas operações, ou seja, esses pesquisadores atuavam no nível dos processos de comunicação responsáveis pelo seu equilíbrio.

Denominada por Wiener de cibernética, que deriva da palavra grega kybernetes (piloto), no sentido daquele que governa, a nova ciência foi definida como a "ciência do controle e da comunicação no animal e na máquina”. Em seu livro Cibernética e Sociedade (1968), Wienerjustifica colocar o controle e a comunicação dentro da mesma classe porque, segundo ele, ao se comunicar com uma outra pessoa se transmite uma mensagem, e ela ao replicar de modo conexo, o faz com uma informação "que lhe é originariamente acessível", e não ao primeiro (1968, p. 16). Assim, complementa o autor, é função daquele que recebe a mensagem discernir se compreendeu ou não. Esse fluxo de comunicação e controle representa o principal conceito da cibernética, que é o processo de retroalimentação, pelo qual informações são trocadas entre sistema e ambiente como meio de manutenção do equilíbrio.

A retroalimentação, também denominada de feedback, é um processo circular de comunicação entre elementos

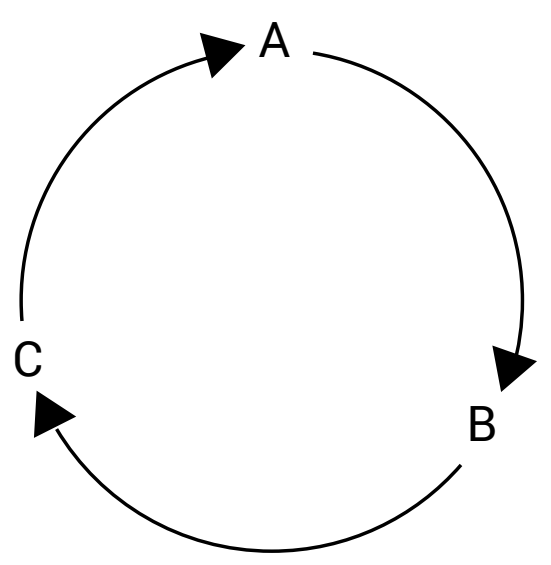

Causalidade Circular de um ciclo de retroalimentação (feedback), baseado em Capra (2016, p. 123) 


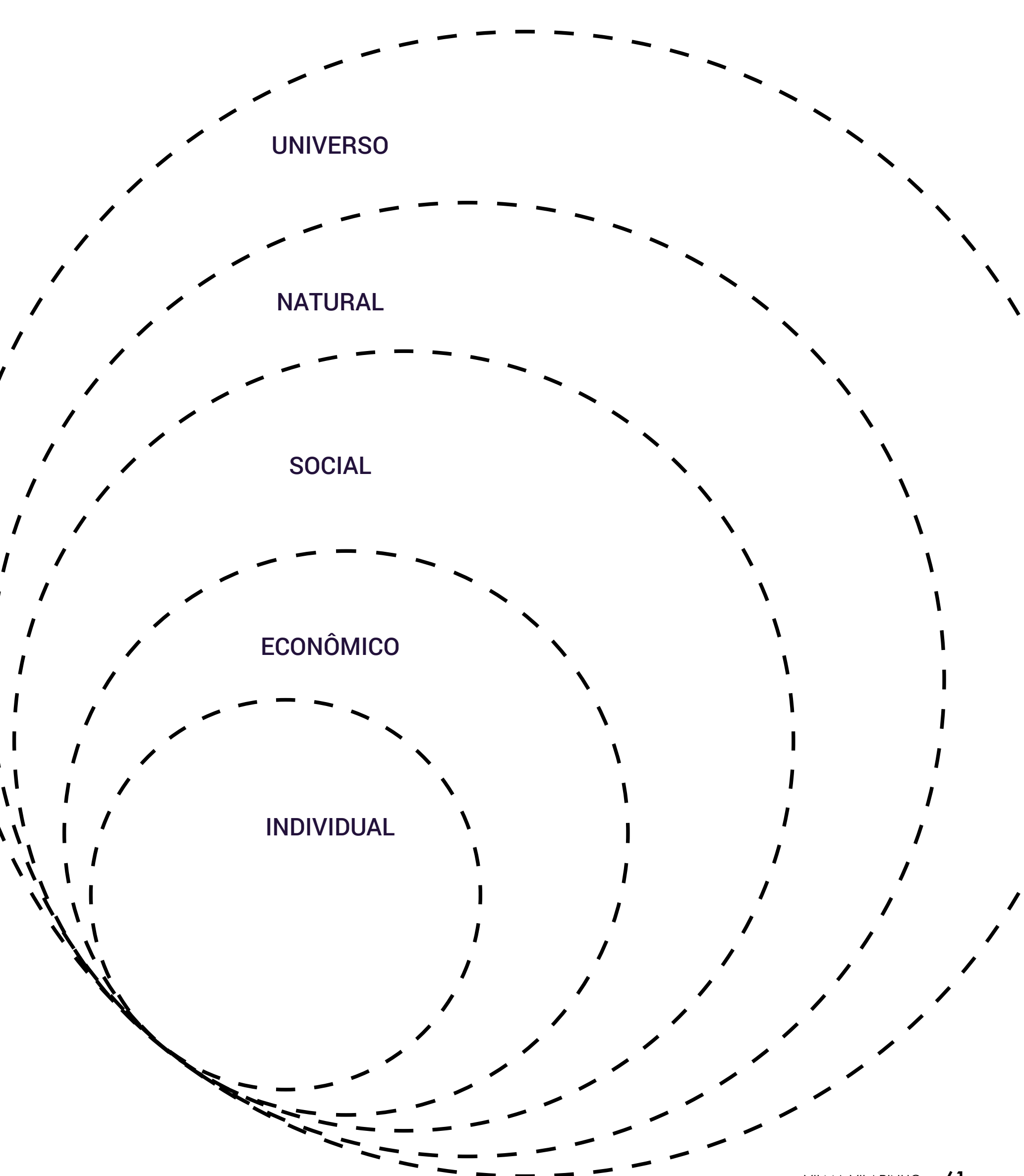

VILMA VILARINHO

61 



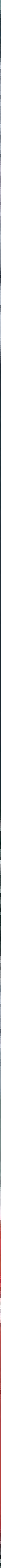


causalmente interligados, dentro do qual uma causa inicial sobre um elemento se propaga sobre os demais provocando-lhes efeitos a serem abordados de modo específico por cada um e assim ocorre até que o último da cadeia retroalimenta o primeiro A formulação do conceito desse ciclo introduziu novas percepções a respeito de como alguns processos autorreguladores ocorrem em sistemas vivos. O principal deles diz respeito a ubiquidade desses ciclos. Embora não sejam visíveis, há plena consciência de que existem e se organizam por padrões de rede não lineares.

Em termos gerais, sistemas cibernéticos apresentam quatro características fundamentais: 1) possuem capacidade para perceber; 2) para avaliar, 3) identificar desvios e 4) empreender ajustes de autorregulação. Assim, são mecanismos de controle que realizam processos de regulação através de loops de retroalimentação com feedbacks positivos e negativos. Isto quer dizer que o produto de saída de um sistema cibernético em interação com o ambiente retorna a ele como uma nova informação, a qual desencadeará ou não em novos ajustes, para que o propósito se realize.

Ciente de que o conceito de retroalimentação tinha abrangência maior do que apenas lidar com organismos vivos, sendo também passível modelar e compreender sistemas sociais, Wiener afirmou que era "certamente verdadeiro o fato de que o sistema social é uma organização como o indivíduo, que é mantida coesa por um sistema de comunicação", o qual segundo ele se caracteriza por uma "dinâmica na qual processos circulares da natureza da retroalimentação desempenham um importante papel” (1968, p. 24).

Posteriormente, ele retoma esta visão e diz que "a sociedade só pode ser compreendida através de um estudo das mensagens e das facilidades de comunicação de que disponha" (1968, p. 16). Esta concepção permite que se olhe para sistemas sociais sob a ótica da retroalimentação, considerando a comunicação como um lugar para se re- 
fletir sobre processos de autorregulação, sejam eles entre indivíduos ou entre estes e sistemas artificiais.

A natureza desse campo de pesquisa atraiu um grupo de estudiosos com perfis distintos dos biólogos e ecologistas, primeiros construtores da teoria dos sistemas. O núcleo se ampliou e passou a ser composto por, além de filósofos e matemáticos como N. Wiener, também por engenheiros, neurocientistas, matemáticos e cientistas sociais, o que proporcionou o surgimento de uma nova visão sobre a organização de sistemas vivos, que buscava lidar com o "problema do controle e da comunicação em geral", sob o propósito de "desenvolver uma linguagem e técnicas" (WIENER, 1968, p. 17) que, de fato, capacitassem os ciberneticistas a lidarem com ele.

Por uma perspectiva de organização social, Luhmann explica que a cibernética "é antes de tudo um processo que procura diminuir as diferenças entre o fim proposto e a realidade" (1995, p. 217), ou seja, há uma busca pela sociedade pela manutenção de um equilíbrio que precisa lidar com contextos de complexidade de uma realidade muitas vezes adversa, cujos desafios são maiores do que cada indivíduo em particular, embora, de modo distinto, faça parte de cada um.

Nobert Wiener (1968) aborda a comunicação e o controle dentro da mesma classe. Segundo ele, se a comunicação pode ser entendida como o processo básico de estabilidade das relações humanas, os sistemas cibernéticos, podem ser considerados como uma instância de controle.

Concebida em um contexto de exploração de sistemas de controle durante meados e final do século XX, a cibernética resultou de esforços interdisciplinares sobre sistemas de regulação baseados em processos de comunicação entre ambiente interno e externo. Este seria um forte motivo de aproximação da teoria geral de sistemas, ao se buscar na dinâmica de sistemas orgânicos respostas 
para o desenvolvimento de máquinas de regulação. Essa compreensão fundamentará o "futuro desenvolvimento dessas mensagens entre o homem e as máquinas, entre as máquinas e o homem, e entre máquina e máquina” (WIENER, 1968, p.16). Neste sentido, ter uma visão geral da cibernética, que se relaciona intimamente com a teoria dos sistemas, é imprescindível para se compreender a dinâmica por detrás das trocas, das interações que mantém a vida no complexo ambiente social.

O ponto de partida da elaboração formal da cibernética enquanto ciência, ocorre com a chegada do cientista Heinz von Foester (1949), nos Estados Unidos, para ingressar no time de pesquisadores da Universidade de Illinois, onde assume poucos meses depois o cargo de diretor do departamento de engenharia elétrica, passando a interagir com pesquisadores ciberneticistas da Fundação Josiah Macy ${ }^{9}$ (LUHMANN, 1995), instituição onde a cibernética se consolida, através do trabalho desenvolvido pelo grupo denominado Macy Conferences, entre os anos de 1946 e 1953, do qual N. Wiener também é parte.

Além de von Foester e Wiener, estavam ainda o antropólogo Gregory Bateson, o matemático John von Neumann e o teórico da informação Claude Shannon, nomes que entrariam para a história dos sistemas cibernéticos, entendidos como modelos de processos de comunicação que viriam a ser a base de muitos dos sistemas utilizados pela sociedade contemporânea.

Foester funda, em 1957, o Biological Computer Laboratory, do qual após estudos sobre problemas da cognição e auto-organização viria a conceber sua própria teoria da observação, sob o título de cibernética dos sistemas que observam - ou cibernética de segunda ordem ${ }^{10}$, que inaugura uma nova fase dos sistemas cibernéticos, caracterizada pelo diferencial de sistemas não mais como máquinas de observação somente, mas também como
9 Fundação filantrópica com foco em problemas do sistema nervoso, onde foram realizadas uma série de conferências sobre cibernética entre os anos de 1946 e 1953.

\footnotetext{
10 Em VANDERSTRAETEN, Raf. Observing Systems: a cibernetic Perspective on System/Environment Relations. Malden, EUA. Journal for the Theory of Social Bahavior 31. 2001
} 
sistemas capazes de se auto-observar. Nesta concepção, o observador não está fora da situação que ocorre, pelo contrário, está tão inserido nela quanto os elementos que participam do processo.

A teoria de von Foester possibilitou futuras explorações não somente no campo da computação, com o desenvolvimento de máquinas capazes de processar dados e realizar observação recursivas, como os sistemas de previsão climática, mas também no campo da sociologia, que explora a teoria pela perspectiva de observador/sujeito, aquele que faz parte do processo de observação como elemento a também ser observado.

Sobre a relação entre sistemas que observam e a sociologia, Luhmann diz que "observar é a operação, enquanto que observador é um sistema que utiliza operações de observação de maneira recursiva", isto quer dizer, dentro de uma perspectiva filosófica, na qual o conceito de cibernética se desenvolve, que a atividade da observação está sob condição de um conjunto de fatores, passíveis de serem pré-definidos e estarem condicionados as estruturas do sujeito que observa. Luhmann afirma que para "que o observador possa observar as operações, ele próprio tem de ser uma operação" (1995, p.154).

O conceito de sistemas que observam coloca em questão para aquele que o projeta, que as operações a serem realizadas futuramente serão projeções dos limites de sua própria estrutura de criador. Neste sentido, o sistema projetado para observar será, salvo as potencialidades de escala das máquinas artificiais, um reflexo de sua própria condição de observador. 


\section{3}

\section{DESIGN E COMPLEXIDADE}

O pensamento complexo e a teoria dos sistemas abrem espaço para um conhecimento holístico que se debruça sobre a realidade a partir do entendimento de que esta não cabe mais numa ciência compartimentalizada e seccionada. No entanto, essa outra forma de fazer ciência traz também algumas questões: se tudo está relacionado, qual o limite da ação do homem sobre o que quer conhecer e intervir? Em que momento se estabelecem as fronteiras entre os fenômenos e/ou coisas de modo a que o pesquisador não se perca numa rede sem fim ou paralise diante da imensidão do problema com o qual se defronta? Como agir diante dessa realidade que não pode mais ser isolada? A consciência da realidade como complexa e sistêmica exige uma nova práxis que demanda por outras ferramentas e desafia o paradigma clássico da relação entre sujeito e objeto. Qualquer atitude, neste contexto, pressupõe a indissociabilidade desses dois atores que se tornaram interatores, sem mais a figura do sujeito sobreposto ao objeto. Se for necessário pode se considerar essa relação como sistemas afeitos a influencias mútuas.

A partir desse entendimento, os problemas que afligem a humanidade não se restringem mais a uma situação restrita. A ordem dos acontecimentos é muito mais abrangente do que se imaginava quando parecia que cada território, povoado ou nação estavam circunscritos a si mesmos ou quando a ciência assumia o método cartesiano como seu modo de operação. A globalização 
há muito iniciada, impulsionada pelos transportes e pela comunicação em massa inicialmente e, contemporaneamente pela Web, amplia não só a concepção de que os seres vivos de qualquer natureza estão num mesmo ambiente, como indica a todo momento que os efeitos e as consequências das intervenções humanas sobre o planeta não se restringem ao lugar geográfico onde ocorrem, e que as questões políticas e geopolíticas estão a cada dia mais entrelaçadas, demandando por normas e legislações que acompanhem de modo mais rápido o que se apresenta como realidade.

Assim se redefine o conceito de globalização, entendido num primeiro momento pelo viés econômico e depois por um viés sociocultural e político que envolve tanto a formação de instituições de regulação mundial, como a Organização Mundial do Comércio, a ONU, os tribunais internacionais, quanto um fluxo de pessoas que transitam entre as nações em atividades que trazem para a agenda global questões relacionadas aos direitos humanos, às guerras, aos fluxos migratórios e às epidemias, citando apenas alguns. Essa passagem do econômico para o social, revela uma dinâmica que ao fim envolve pessoas e meio ambiente e confere ao fenômeno da globalização qualidades que o tornam cada vez mais sistêmico e complexo. Ainda nesta primeira metade do século XXI, as animosidades estão mais explícitas e expostas o que gera uma situação instável tanto para os diretamente envolvidos quanto para quem busca se colocar à parte.

A imagem e o consumo tornam-se dois elementos fundadores da contemporaneidade. A sociedade informacional, como a ela se refere Manuel Castells (1999), se traduz, fundamentalmente, por essas duas práticas. Empresas americanas, como o Facebook e o Instagram, tornam-se a cada dia mais indispensáveis para um imaginário construído para as telas dos dispositivos eletrônicos. O capitalismo 24/7 (CRARY, 2014), entronizado pela Amazon, 
se apresenta como disposto a responder aos desejos dos consumidores e daqueles que não encontram mais hora para não trabalhar. O tempo 24/7, segundo Crary, “é um tempo de indiferença, ao qual a fragilidade da vida humana é cada vez mais inadequada, e onde o sono não é necessário nem inevitável.” (2014, p.19). Fazer-se presente, não se deixar esquecer, consumir coisas e imagens traduz a preponderância de sentimento de virtualização de uma vida aparentemente sem espaços limitantes. No entanto, essa ideia esbarra nos muros e fronteiras reais a serem superadas, nos corpos e angústias dos que se deparam com uma realidade exaustiva e que sabem o que é fazer parte de um cotidiano e de um sistema produtivo incansável, urgente e novidadeiro. Crary considera a afirmação de Bernard Stiegler para explicar que se o esperado da globalização era um mundo multicultural, plural estruturado sobre uma esfera pública eletrônica e o que ocorreu, segundo Stiegler, a partir de 1990, foi uma hiperindustrialização onde a produção em massa se alinhou a técnicas que juntaram produção, distribuição e subjetivação em escala planetária.

A experiência do sujeito, portanto, também se constrói de outro modo. $\mathrm{O}$ alcance da comunicação digital faz com que tanto no trabalho quanto na vida cotidiana esse sujeito sinta-se parte de algo maior, enredado nas tramas e narrativas construídas coletivamente, onde ele se torna um ponto desse emaranhado de opiniões, informações e imaginários de todos os tipos. A presença das máquinas de comunicar e expor transforma a experiência territorial, acelera a velocidade de apreensão e de interpretação da realidade, construída cada vez a partir de uma espécie de colagem de fragmentos que formam uma imagem de mundo sujeito a instabilidades e mudanças repentinas, carregadas de uma efemeridade com força contextual e ou estrutural inédita. Felix Gauttari analisa a situação afirmando que "nossas funções orgânicas, nossos fantasmas, nossos reflexos etológicos se encontram maquinicamente ligados em um 


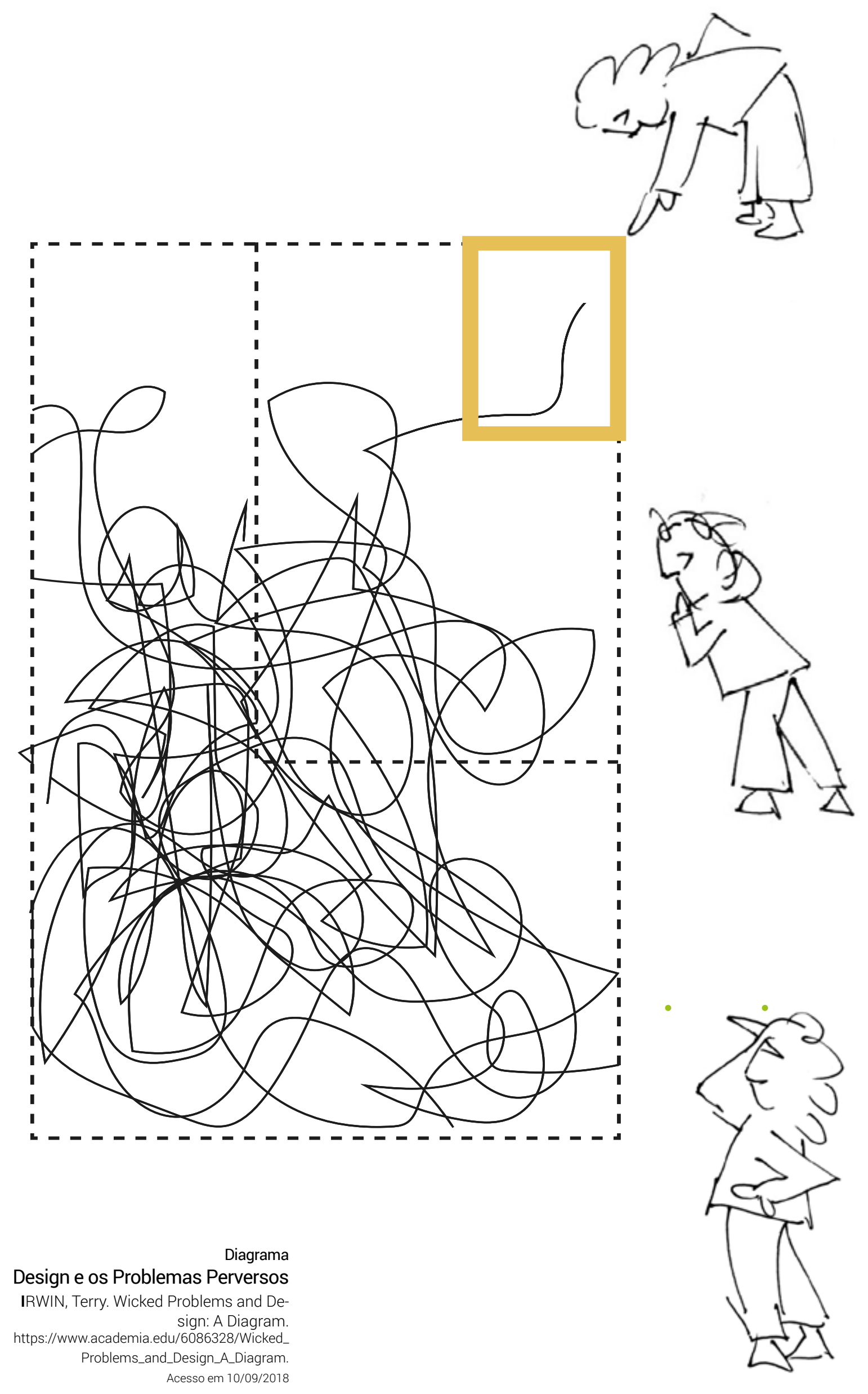



mundo técnico cientifico que está realmente engajado em um crescimento louco" (1992, p.159).

Esse estado de transe planetário demonstra a cada dia a necessidade de que os teóricos da complexidade e a teoria dos sistemas ultrapassem seus limites ou seus sustos em direção a um lugar de ação. Esse lugar pode ser o do Design com seu modus operandi apoiado sobre um fazer projetual, entendido como um instrumento fundamental para a organização de processos que não conseguem mais se fechar em certezas antecipadoras e que adotam como ponto de partida o entendimento de que tanto as perguntas quanto as respostas não estão dadas a priori e que a problematização é uma construção necessária ao enfrentamento do que se denomina problemas planetários e ou problemas capciosos, difíceis não só de serem circunscritos a uma ação local, mas também por reverberarem em campos diversos. Esses problemas são aparentemente constituídos por elementos independentes, o que pode levar ao equívoco de que podem ser abordados em partes isoladas, resultando em respostas ineficientes, que pouco ou nada resolvem.

Ao se considerar que uma parcela significativa de tudo o que nos cerca no mundo se qualifica como sistema, seja na esfera do ambiente natural, do social e do mundo construído, esta constatação desafia a todos, em especial ao campo do design, a atuar como um agente mediador entre estes três sistemas, de forma a aprender a ler, compreender e descrevê-los. Essa atitude é imprescindível, tanto na ordem da pesquisa, quanto na ordem de projeto, de modo a se desenvolver um certo grau de formalismo no sentido de que sua caracterização seja passível de descrição e representação. Torna-se, portanto, imprescindível que se tenha uma visão geral do que se define por sistema em termos de anatomia e dinâmica, aspectos que, segundo Irwin (2012), são desafios postos ao design enquanto elaboração de processos. 
O Design amplia sua área de atuação, tornando-se estratégico, cada vez mais interdisciplinar e cada vez mais consciente de que suas ações são parte de um esforço de enfrentamento desses problemas, e que necessitam de uma rede de agentes com capacidade de intervenção em níveis diversos. Sobre esse aspecto de abordagem do problema, Irwin (2012) ressalta que embora uma série de estratégias tenham sido elaboradas com foco na classe de problemas definida por Rittel e Webber, "os esforços não têm sido direcionados para a compreensão de sua dinâmica e anatomia" o que, ainda segundo Irwin, "é crucial para o desenvolvimento de soluções significativas para eles" (2012, p. 3). Há de se pensar que para enfrentar problemas capciosos, numa perspectiva complexa e sistêmica, o Design deve assumir-se também sistêmico, como uma prática integrada que não cabe nas formações específicas, mas numa ação integrada impulsionadas por vários atores, mesmo os que não são designers de formação, e pela relação que emerge entre vários subsistemas.

Necessário deixar claro que apesar das especificidades de cada área do design (industrial ou de produto, gráfico, digital, de serviços) a concepção de projeto, assentada sobre metodologias - que muitas vezes se demonstram falhas quando pensadas a priori - é o ponto da rede a aproximar as diferenças em prol de uma atividade estratégica orientada a problematizações e proposições voltadas para soluções ou antecipações diante do que pode ser evitado. Se estabelece, dessa forma, uma rede complexa de profissionais que trazem, a partir da observação de que é necessário compartilhar e colaborar, seus conhecimentos e expertises no enfrentamento de problemas complexos graves, escaláveis e difíceis de serem contidos.

Peter H. Jones (2014), ao discutir esse design sistêmico, a partir da referência de Bousbaci (2008) constrói uma tabela sobre o que ele denomina as três gerações do design. 


\section{Compatible philosophies, dif ferent generations}

\begin{tabular}{|c|c|c|c|c|}
\hline Generation: & First & Second & Third & Fourth \\
\hline Philosophy & $\begin{array}{l}\text { Rational } \\
1960 \text { 's }\end{array}$ & $\begin{array}{l}\text { Pragmatic } \\
1970 \text { 's }\end{array}$ & $\begin{array}{l}\text { Phenomenological } \\
1980 \text { 's }\end{array}$ & $\begin{array}{l}\text { Generative } \\
2000 \text { 's }\end{array}$ \\
\hline Methods & $\begin{array}{l}\text { Movement from } \\
\text { craft to } \\
\text { standardized } \\
\text { methods }\end{array}$ & $\begin{array}{l}\text { Instrumentality, } \\
\text { Methods } \\
\text { customized to } \\
\text { context }\end{array}$ & $\begin{array}{l}\text { Design research and } \\
\text { stakeholder methods } \\
\text { Design cognition } \\
\text { User-centered }\end{array}$ & $\begin{array}{l}\text { Generative, empathic } \\
\text { \& transdisciplinary } \\
\text { Human-centered }\end{array}$ \\
\hline $\begin{array}{l}\text { Authors \& } \\
\text { trends }\end{array}$ & $\begin{array}{l}\text { Simon, Fuller } \\
\text { Design } \\
\text { Science } \\
\text { Planing }\end{array}$ & $\begin{array}{l}\text { Rittel, Jones } \\
\text { Wicked problems } \\
\text { Evolution }\end{array}$ & $\begin{array}{l}\text { Schon, Don Norman } \\
\text { User-centered \& } \\
\text { Participatory Design } \\
\text { Reflective action }\end{array}$ & $\begin{array}{l}\text { Dubberly, Sanders } \\
\text { Generative Design } \\
\text { Service Design } \\
\text { Systemic design }\end{array}$ \\
\hline $\begin{array}{l}\text { Systems } \\
\text { influences }\end{array}$ & $\begin{array}{l}\text { Sciences, OR } \\
\text { Cybernetics }\end{array}$ & $\begin{array}{l}\text { Natural systems } \\
\text { System dynamics } \\
\text { Systems engineering }\end{array}$ & $\begin{array}{l}\text { System dynamics } \\
\text { Social systems } \\
\text { Soft systems }\end{array}$ & $\begin{array}{l}\text { Complexity } \\
\text { Socio-ecological } \\
\text { Dialogic }\end{array}$ \\
\hline
\end{tabular}

Classificação de Rabah Bousbaci, em Systemic Design Principles for Complex Social Systems- Peter H. Jones. https://www academia edu/4270934/Models of_Man_in_Design_Thinking_The_Bounded_Rationality_Episode
A primeira geração buscava aproximar o design da ciência, desenvolvendo procedimentos e métodos, a partir de uma perspectiva racional, prescritiva e dada a generalizações. Herbert A. Simon e Buckminster Fuller são dois dos seus principais autores. Para Simon, o design é uma atividade voltada para a resolução de problemas. Sobre essa perspectiva uma questão a mais se coloca: seria o design uma ciência pura ou aplicada. A segunda geração, assentada sobre o pragmatismo, propunha métodos adaptados aos contextos. Os projetos não se desenvolveriam como métodos decididos a priori, ao contrário, a partir de uma leitura do problema e da situação se definiriam procedimentos que possivelmente só seriam necessários em casos particulares. Os teóricos dessa geração, Horst Rittel e Melvin Webber, se voltavam para o que denominaram de wicked problems, como o que não pode ser abarcado por modelos teóricos científicos na medida em que cada problema tem características próprias que envolvem pessoas e contextos sociais diversos.

As duas últimas gerações apontadas por Jones se referem a uma teoria fenomenológica e a generativa. A pri- 
meira se volta para o usuário com centro do processo e para um design participativo, uma tendência de projeto que surge nos anos 1980 e que ainda se apresenta com bastante força nesta primeira metade do século XXI. Por fim, a quarta geração põe em pauta um design generativo como o que traz para o processo as pessoas envolvidas no processo, a partir de um trabalho que pressupõe cooperação, compartilhamento e decisões tomadas em conjunto. O designer, neste caso, torna-se uma espécie de estrategista, capaz de facilitar relações e trabalhar com pessoas. É necessário apontar para a complexidade dessas relações e que o mais importante nessa postura é o exercício da escuta, da empatia e da capacidade de aproximar campos interdisciplinares. A pesquisa do design generativo vai além de por o usuário no centro, o que está em jogo é o ser humano como um agente de transformações sociais, políticas estéticas e éticas. Por isso a necessidade de que ações e reponsabilidades sejam compartilhadas. 
2

$\mid$

IMIGRAÇÃO

NO BRASIL

o legado de um passado 
Chegada de Italianos de navio

https://www.pesquisaitaliana.com.br/viagem-

-de-navio-entre-a-italia-e-o-brasil/ Acesso 23 de maio de 2017 


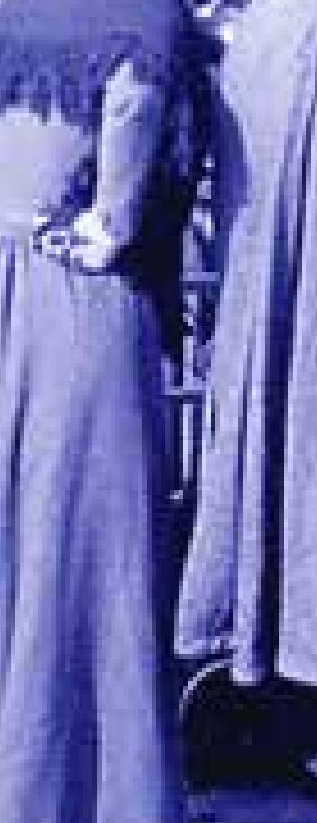

जिए

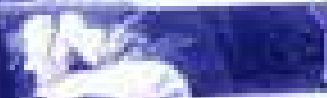

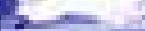
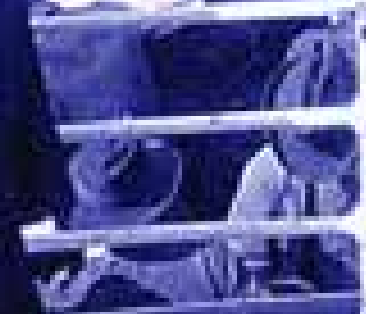

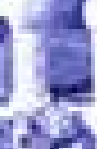

Ca
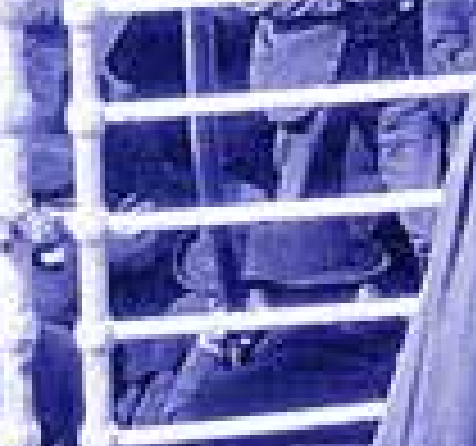
O movimento de grupos sociais é um dos fenômenos mais importantes para o entendimento do que ocorre no planeta, desde a prática do nomadismo com ausência de territórios nacionais e fronteiras políticas até o momento em que o modo de vida humano passa a ser sedentário e se estabelece a partir da apropriação de lugares e da conformação de culturas que se constituem de formas diferenciadas. A migração como um ato social se traduz pelo deslocamento de indivíduos solitários ou em grupo, justificado pela busca de melhores condições de vida e de mais oportunidades. À essa perspectiva soma-se a política, quando esse deslocamento se dá entre Estados Nação, o que envolve procedimentos normativos, classificatórios, direitos e deveres do migrante.

Esse fluxo de pessoas traz consigo uma pluralidade de manifestações que afeta o ambiente de chegada em dimensões distintas modificando, em maior ou menor grau, a economia, a cultura, as crenças e as ideologias dos grupos/lugares que as recebem ${ }^{14}$. As migrações podem ser movimentos únicos, sem precedentes, completamente imprevisíveis, mas podem também reproduzir padrões, na medida em que envolvem características comuns dadas, por exemplo, pela legislação do lugar de destino. As imprevisibilidades ocorrem em situações em que as regras e normas não dão conta do que de novo esse fluxo provoca em cidades, bairros e junto às comunidades em que essas pessoas se estabelecem.

É notório que a temática da migração está entre os importantes fenômenos que, ao longo da história da humanidade, contribuíram para o que denominamos sociedade. A migração se manifesta a partir de diferentes motivações, as quais invariavelmente estão relacionadas a uma partida e uma chegada, como lugares de "expulsão e de atração" (BAENINGER; BRAGA; TEIXEIRA, 2012, p. 35). Deixa-se uma realidade indesejada, perigosa, miserável, cruel em busca de outra que pode significar uma vida mais aus-

14 Há de se considerar que a influência em diversos aspectos é mútua e com impactos diferentes. 
piciosa e promissora e talvez esse novo lugar seja também o destino daqueles que ficaram para trás. Estes dois fatores de expulsão e de atração são nomeados pelos termos emigração e imigração, respectivamente. Assim, tem-se a priori três padrões, todos como verbo e substantivo: migrar/migração, emigrar/emigrante e imigrar/imigrante. São ações que tem como resultante um sujeito histórico, definido como quem veio de fora, um estrangeiro que mesmo integrado socialmente, carrega as marcas de ser um outro, alguém que busca ser aceito ao mesmo tempo que resiste, consciente ou inconscientemente, a se integrar definitivamente à nova realidade.

As migrações são processos dinâmicos e vivos, com estruturas que emergem de uma miríade de variáveis sujeitas aos fatores espaço/tempo tornando-se, dessa forma, impossíveis de serem apreendidas por completo. Trata-se, segundo Baeninger, Braga e Teixeira (2012), "da diversidade dos espaços e temporalidades" pelos quais cada um que migra flui. Neste sentido, complementam:

“os migrantes não apenas são capazes de circular, mas de apropriarem-se desses espaços, então, produzindo territórios e participando da criação de riquezas de novas identidades sociais. Assim, há um deslocamento do olhar da migração para os sujei-tos dessa ação - os migrantes - enquanto sujeitos que, embora condicionados por condições estrutu-rais, econômicas, sociais, políticas e culturais, tam-bém, atuam sobre essas condições, significando-as, atribuindo-lhes significados a partir de seus projetos de vida individuais e familiares." (2012, p. 35)

A condição de migrante é outro padrão a se desenhar, trazendo consigo potencialidades que se manifestarão em relação a outros lugares e outros sujeitos. Os autores chamam atenção para o fato que, "há um deslocamento do olhar da migração para os sujeitos dessa ação" (2012, p. 35). 
Entre a diversidade de interesses que o processo migratório desperta em vários campos do conhecimento, como o da economia, política, educação, psicologia, sociologia, antropologia, legislação, relações internacionais etc., um aspecto que certamente perpassa a todos é o de sua complexidade e a certeza de que não há apenas um modo de atravessar essas temporalidades, seus espaços e os envolvidos. Esses atravessamentos ocorrem a partir de padrões e de particularidades expressas por desvios e emergências.

Como mencionado anteriormente, haverá sempre um motivo para emigrar e um outro para a escolha do destino. Esses dois fatores apresentam pontos relevantes ao entendimento do movimento migratório. E possível destacar dois motivos principais que levam ao desejo e efetivação da emigração: primeiro o que se fundamenta em um processo racional, predominantemente de cunho econômico, como a Crise ecônomica Mundial em 1929 ou o crescimento industrial durante a década de 1950, eventos que tiveram fatores de repulsão e de atração a emigração e imigração. Estas são mudanças focadas na busca por trabalho, no desejo de empreender ou na busca por capacitação/estudos, e caracterizam os primeiros movimentos migratórios tanto dentro do Brasil, quanto originários de outras nações. Necessário se apontar para o estado de São Paulo, como polo atrator.

Como outra causa, há os fluxos originários de crise internacionais, provocados por situações humanitárias críticas, capazes de agregar uma outra identidade para o imigrante: a de refugiado. Em geral os contextos desses indivíduos se baseiam no desejo de sobrevivência provocado pelo risco de morte decorrente de algum tipo de perseguição. Neste sentido, não há um projeto de mudança de vida. Para muitos, o sentimento mais presente é o de sofrimento pela saída ou até mesmo fuga de seu país e distanciamento forçado de sua cultura, de seu cotidiano e de sua família, amigos e parentes.

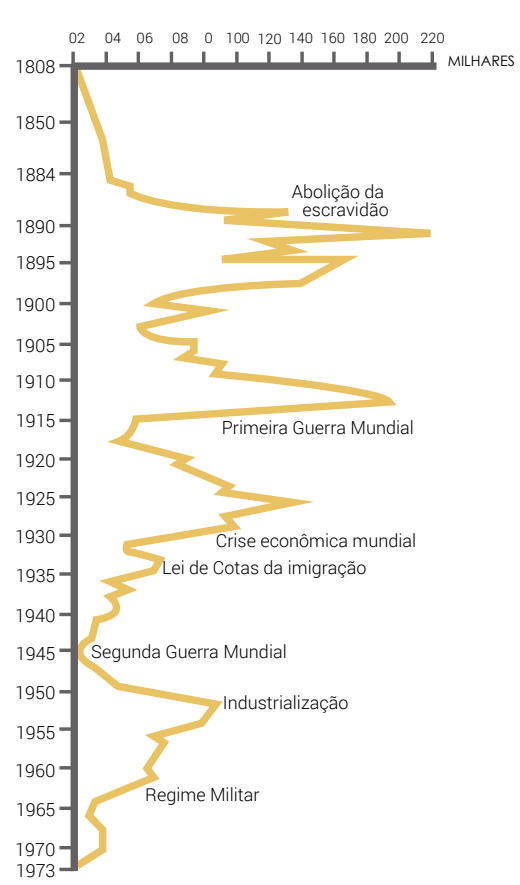

Entrada de Imigrantes no Brasil http://marcosbau.com.br/geobrasil-2/imigracao-e-migracao-no-brasil/ Acesso em 17 de utubro de 2018 
A escolha para onde ir está intrinsicamente relacionada a essas duas categorias: para o migrante estarão em questão o potencial econômico, a viabilidade de deslocamento, as variavéis relacionadas ao domínio da língua, a conseguir uma acomodação, a possibilidade de se adpatar culturalmente, a conexão com alguém conhecido ou indicado, ao amparo legal etc.

O refugiado, por sua vez, recorre primeiramente aos mecanismos de amparo legal, considerando a sua condição de vítima de crises humanitárias. Assim, muitas vezes acaba por buscar países que lhe abrem as fronteiras, mas que nem sempre trazem condições que o façam sentir-se acolhido, seja pelo estranhamento da cultura, seja pela barreira linguística ou até mesmo pelo isolamento ou auto-isolamento social.

Com a finalidade de traçar um breve relato sobre as distinções que envolvem essas duas categorias de migrantes, nos dirigiremos ao passado das migrações internacionais no estado de São Paulo tendo como estrutura de fundo as razões de saída, as de escolha de destino e as condições dadas pelo ambiente que os acolheu. 


\section{1}

\section{A IMIGRAÇÃO DE ONTEM SOB A PERSPECTIVA DA SAIIDA, DA CHEGADA E DA ACOMODAÇÃO}

O Brasil é um universo de sobrenomes, fato que constata seu caráter multiétnico, formado por grupos que buscam manter suas tradições e culturas vivas, como ocorre entre japoneses, italianos, portugueses, turcos, bolivianos etc. Essa organização social teve início ainda no final do século 19, sob fluxos migratórios estimulados por razões distintas, que se desdobraram nas diversas estabilizações do que somos hoje. Segundo o geógrafo Adas Melhem (2004), o crescimento da população brasileira foi significativamente influenciado pelas imigrações até 1930, tendo seu declínio a partir da década seguinte em decorrência da criação da Lei de Cotas da Constituição de 1934, que limitava a entrada de imigrantes a $2 \%$ da população estrangeira já no país nos últimos cinquenta anos (2004, p. 282).

Durante os períodos de fluxo maior de imigrantes, são localizados ao longo da história eventos que tiveram os efeitos de "expulsão e de atração" (BAENINGER; BRAGA; TEIXEIRA, 2012, p. 35), aqueles que provocaram a saída e os que favoreceram a escolha de para onde ir. Entre os fatores de atração estão: o crescimento do Brasil como produtor de café, o que demandou por uma quantidade maior de mão de obra; a criação da Lei Eusébio de Queirós (1850), que tornou ilícito o tráfico de escravos; a iniciativa dos produtores de café em custear as despesas dos imigrantes com hospedagem e 
alimentação durante o primeiro ano, em paralelo ao apoio do governo responsável pelo custeio das passagens até o ano 1889, período posterior a abolição da escravidão, o que levou o movimento de imigração ao seu maior fluxo.

De outro lado, alguns imigrantes como italianos, portugueses, alemães e espanhóis foram expulsos de seus países por eventos como o as transformações socioeconômicas na Itália que dificultaram a posse da terra (1861); a Primeira Guerra Mundial (1914 - 1918) e a crise econômica mundial, conhecida também como "a grande depressão", iniciada em 1929 com a quebra da bolsa de Nova Iorque e mantida ao longo da década seguinte. Dois eventos significativos associados aos fatores de atração oferecidos pelos fazendeiros e governo do Brasil, culminaram com a entrada no país de novas culturas, hábitos, práticas e experiências que se fundiriam com a cultura local. Com mão de obra mais especializada do que a dos escravos em métodos de plantio, o imigrante europeu transforma o ambiente agrícola introduzindo novas espécies e processos. Tudo isso contribui para o surgimento de conformações inéditas, que afetam a cada um dos envolvidos e transformam indivíduos e ambiente.

Os japoneses, fluxo seguinte de imigrantes, vieram ao Brasil, especificamente para São Paulo, para substituir parte da mão de obra italiana nas lavouras de café. Eles chegaram posteriormente em decorrência de dois fatores: o primeiro, a restrição de imigrantes asiáticos para países como os EUA, Reino Unido e Austrália, e o segundo, a efetivação de um acordo realizado por Ryu Mizuno, que veio ao Brasil para averiguar o potencial das regiões agrícolas do país para

Propaganda japonesa para atrair imigrantes para o Brasil

(1920)

http://www.brasil.gov.br/old/copy_of_imagens/linha-do-tempo/linha-do-tempo-historia-da-imigracao/1908-cartaz-de-empresa-japonesa/view a mão de obra nipônica, resultando posteriormente em um acordo com o governo de São Paulo.

O anúncio ao lado demonstra de que modo o Brasil foi apresentado como ambiente de atração. No sudeste do 
Japão cartazes diziam que "no Brasil, existe uma árvore que dá ouro: o cafeeiro. É só colher com as mãos". Os trabalhadores japoneses eram chamados de "soldados da fortuna”. Em síntese, os processos migratórios abordados até aqui foram motivados pela necessidade, pelo desejo de obter uma vida melhor, e estavam condicionados ao desenvolvimento econômico por meio do trabalho.

Desde sua colonização pelos portugueses, houve no Brasil uma série de fluxos migratórios, como a chegada de suíços na cidade do Rio de Janeiro em 1818, de alemães no Rio Grande do Sul a partir de 1824, posteriormente indo também para São Paulo, em 1829. Esses imigrantes organizaram diversos agrupamentos de pessoas em espaços geográficos que mais tarde viriam a se tornar cidades, como Novo Hamburgo, Blumenau, Itajaí, Joinville, entre outras. Ambientes que foram influenciados pela herança cultural de seus fundadores, manifesta na arquitetura de suas construções, na agricultura, na gastronomia, no entretenimento, na religião, em seus hábitos sociais.

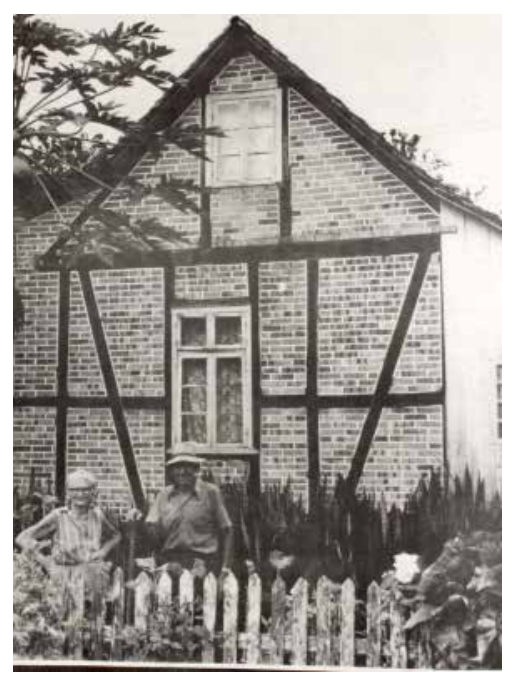

Casa de imigrantes alemães na cidade de Blumenau -

reprodução da arquitetura do país de origem. http://hemeroteca.ciasc.sc.gov.br/jornais/boidemam\%C3\%A3o/BOI1981006.pdf

Acesso em 05 de junho de 2018 




\section{IMIGRAÇÃO COMO PROJETO}

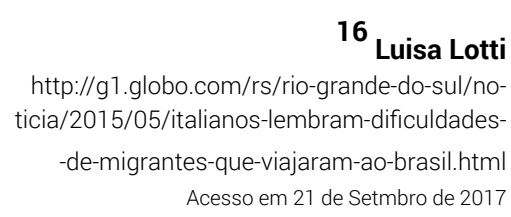

Imagens página anterior

1938

Portugueses na hospedaria de Imigrantes

1930

Imagem mostra a partida de navio transportando imigrantes japoneses com destino ao Brasil, na década de 1930, Japão

1950

emigrantes espanhóis partindo com destino ao Brasil

1923

Exemplar de passaporte de família alemã

1925

Passaporte de imigrante português de

1808

Decreto que concede terras aos estrangeiros

1915

Foto de escola de colônia alemã em Cosmópolis (SP),

1920

Família do imigrante português Alfredo Cordeiro, em meio à sua plantação de bananas, no Núcleo Colonial Nova Veneza (Campinas-SP),
Entre os principais fluxos de imigração para o Brasil, uma característica que se repete é o do planejamento e da não aleatoriedade. Houve um plano que estruturou esses movimentos desde a partida, chegada e permanência em território brasileiro. Como visto anteriormente, houveram algumas crises, dentro e fora do Brasil, que favoreceram ou tornaram necessária a elaboração de uma política de atração, seleção e manutenção da mão de obra dos estrangeiros.

Segundo a historiadora Luiza Lotti $(2015)^{16}$, da Universidade de Caxias do Sul, haviam algumas exigências em relação aos imigrantes. Os italianos que quisessem vir para o Brasil, "tinham de ser morigeradas (ter bons costumes) e laboriosos, ou seja, que fossem de bem e fossem trabalhadores", e havia também um limite de idade que, segundo ela, "variava dos 20 aos 35 anos" e por fim, que "viessem acompanhados com a família e que fossem de preferência trabalhadores rurais".

O perfil detalhado acima não indica somente o que se deseja em termos de um perfil para o desempenho de uma função, mas também declara aspectos favoráveis à integração com o novo lugar e sua permanência nele. Desse modo, a probabilidade de que o imigrante corresponda ao que se projetou sobre ele ganha maiores chances de acontecer. Isto porque além de haver um lugar a ser ocupado com determinadas características de operação dentro do 
sistema é sabido que há também um aspecto inerente a todos os indivíduos em questão: a complexidade que os distingue de máquinas desprovidas de reflexão e sentimento. Mantê-los junto dos seus foi uma estratégia para criar dispositivos de equilíbrio para possíveis crises decorrentes da distância do ambiente de origem.

Em seu artigo, "O poder de domar o fraco" (2003), Jair de Souza Ramos coloca em questão a necessidade de se distinguir a imigração da imigração que ocorre sob os arranjos de uma política imigratória. A distinção elementar é a de que a primeira acontece de modo espontâneo e com origens diversas, não se tem uma determinada previsibilidade sobre os pontos de partida, enquanto que a segunda, a subsidiada por políticas públicas, ocorre sob condições de controle de fluxo de partida, chegada e distribuição pelo território. Ramos complementa dizendo que essas iniciativas, que integraram múltiplos atores, foram uma "parcela das complexas e múltiplas interações que estruturaram o processo da imigração de massa” (2003, p.19).

A imigração subsidiada abriu caminhos para que estratégias semelhantes fossem elaboradas e implementadas para fins não somente econômicos, como aconteceu durante o Estado $\mathrm{Novo}^{17}$, no qual uma das principais questões relacionadas a imigração se voltava para o "aprimoramento do povo brasileiro" pelo processo de miscigenação em busca do branqueamento.

Segundo o historiador Fábio Koifman $(2012)^{18}$, em sua pesquisa Imigrante Ideal: O Ministério da Justiça e a entrada de estrangeiros no Brasil (1941-1945), esse era o debate em voga da elite brasileira da época. Em 1930, o então candidato à Presidência da República, Getúlio Vargas, declara que "Durante anos pensamos a imigração apenas em seus aspectos econômicos. É oportuno obedecer agora ao critério étnico" ${ }^{\prime 1}$.

\section{${ }^{17}$ Estado Novo}

foi o regime político brasileiro instaurado por Getúlio Vargas em 10 de novembro de 1937, que vigorou até 31 de janeiro de 1946. Era caracterizado pela centralização do poder, nacionalismo, anticomunismo e por seu autoritarismo.

https://pt.wikipedia.org/wiki/Estado_Novo_(Brasil)

${ }^{18}$ Fábio Koifman

Universidade Federal Rural Fluminense (UFRF)

19 Discurso de Vargas

http://revistapesquisa.fapesp.br/2012/11/12/ os-indesejaveis/

Acesso em 21 de Set. 2017 
A fala de Vargas refletia o pensamento de um grupo de pessoas que acreditava que com este programa de imigração racialmente seletivo, o desenvolvimento do Brasil seria impulsionado uma vez que isto não acontecia devido a "má formação étnica do povo". Nesse sentido, o imigrante ideal seria o homem branco, sem inclinações políticas e católico.

A obra do artista plástico Modesto Brocos y Gomez, A Redenção de Cam (1895), retrata de modo entrelaçado a parábola bíblica sobre a punição de Deus sobre o filho de Noé, Cam - descrito na Bíblia como o possível descendente de raças africanas - com a realidade de pensamento da época: a de que ao longo de algumas gerações, por meio da miscigenação ocorreria o embranquecimento do povo brasileiro. Na obra de Gomez, se percebe pelas três gerações o processo de embranquecimento, sendo este um motivo de agradecimento da matriarca negra, que levanta suas mãos ao céu.

A intenção manifesta em ações práticas se transformou em algumas medidas políticas, decretos e artigos constitucionais, como a obrigatoriedade posta pelo Decreto-lei 3.010 de 1938, do solicitante de visto comparecer pessoalmente ao setor de imigração para que pudesse ser identificado como branco ou negro, além de se verificar também se possuía alguma deficiência física. Outra restrição de entrada no Brasil de determinadas raças, constava no art. $1^{\circ}$ do Decreto 528 de 1890 , que dispunha que a entrada no país de trabalhadores era livre, com exceção dos indígenas da Ásia ou da África, estando esses sujeitos a aprovação do Congresso Nacional.

Entre aqueles que faziam parte dos indesejáveis estavam os estrangeiros considerados intelectualizados, como os “originários da Alemanha, França, Áustria, entre outros países, que produziam reflexões em jornais e livros sobre as mazelas nacionais", diz Koifman (2012). Uma nítida tentativa de criar uma barreira para conter o surgimento 
e avanço de um pensamento crítico e autônomo sobre a realidade local.

Embora amparado por medidas e dispositivos legais, o que se tem como o outro lado da história, segundo o brasilianista Jeffrey Lesser, citado por Koifman (2012), houve uma entrada "expressiva de judeus logo após os decretos restritivos e a absorção expressiva desses grupos ao lado de árabes e japoneses na sociedade brasileira em fins dos anos 1930”. Imigrantes do grupo dos indesejáveis que romperam, em alguma medida, com o planejamento, e de algum modo, criaram novas conformações. 



\section{IMIGRAÇÃO DE SÍRIOS NA CIDADE DE SÃO PAULO}

No final do século XIX, após o período mais intenso dos grandes fluxos de imigração subsidiada para o trabalho nas plantações de café, acontece com maior evidência a chegada de um outro grupo de imigrantes, os de origem árabe, como os provenientes do Líbano, Turquia, Síria, Iraque, Palestina e Egito, países que tinham em comum a língua árabe ou dialetos que dela derivam. Este grupo então se junta a outros imigrantes de diferentes origens, como os italianos, espanhóis, alemães, judeus e japoneses, e se inserem na cultura daqueles considerados os definidores de nossa Nação, "a saber, os indígenas, portugueses e negros” (IBGE, 2007 p. 11).

Segundo a pesquisadora Marília Calegari Quinaglia (2018), embora os imigrantes de etnia árabe possuíssem diversas nacionalidades, o que os caracterizava como um grupo heterogêneo, eram reagrupados, pela língua e porque tinham em comum diversos "aspectos culturais" fatores que contribuíram para "a formação de uma comunidade árabe no país de destino” (2018, p. 94). Separados não chegaram a números tão significativos de imigração, como italianos e portugueses, mas agrupados imprimiram, e continuam a imprimir, marcas significativas na formação da identidade do Brasil (IBGE, 2007 p. 11).

Com fluxos inexpressivos até 1885, a imigração árabe se adensou a partir de 1903 (IBGE, 2007). Segundo estimativa do Museu da Imigração do Estado de São Paulo (MI, 
2016), somente da Síria e do Líbano, os dois maiores fluxos de descendência árabe, entraram no Brasil em torno de 100 mil imigrantes entre os últimos vinte anos do século 19 até 1939, marco do início da Segunda Guerra Mundial.

Segundo levantamento realizado pelo senso de 1920, a distribuição de árabes em território nacional até esse ano, indicava que pouco mais de 50 mil sírios e libaneses viviam no Brasil, dos quais, 19 mil no estado de São Paulo, 9 mil no do Rio de Janeiro e aproximadamente 9 mil em Minas Gerais, estando o restante distribuído por outros estados. A concentração nesses lugares, se justifica em parte pela atração econômica e porque também eram, São Paulo e Rio de Janeiro, os principais pontos de entrada no país.

Imigrantes de outras nacionalidades também foram atraídos pelo território brasileiro, por motivos econômicos, como a oferta de trabalho e de terras, fatores que tornariam possível uma vida autônoma em melhores condições quando comparada às condições do ambiente de origem. Alguns em condições de crise humanitária, que os transformava em refugiados. Foi assim que boa parte dos imigrantes poloneses, russos e judeus chegaram, amparados por organismos internacionais que os auxiliavam com procedimentos legais, com o deslocamento entre um país e outro, e também em sua acomodação no destino.

Como visto até aqui, o Brasil teve vários fluxos de imigração, que por motivos distintos trouxeram diferentes perfis de imigrantes ao seu território, entre eles, os sírios, cujo primeiro fluxo de imigração os agrupa junto com os libaneses, motivo pelo qual, são mencionados como "imigrantes sírio-libaneses" ou imigração "sírio-libanesa". Tal denominação se deve ao fato de que até a I Guerra Mundial o Líbano fazia parte da Síria, sendo ambos dominados pelo Império Otomano ${ }^{20}$, o que fazia com que recebessem até 1892, passaportes turcos. Fato que segundo Maria Lúcia Mott, "para a maioria síria e libanesa

\section{${ }^{20}$ Império Otomano}

Até início da Primeira Guerra Mundial, a região conhecida como Grande Síria, ou simplesmente Síria, pertencia ao Império Otomano e incluía o Líbano entre suas fronteiras. Depois da derrota turca, a França assumiu o controle político da região e estabeleceu o regime de protetorado, que concedia certa autonomia a Líbano. Tanto a Síria (capital Damasco) quanto o Líbano (capital Beiture) definitivamente lograram a independência em 1946 e 1943 respectivamente.

Fonte: Artigo: O lugar certo na época certa: sírios e libaneses no Brasil e nos Estados Unidos - um enfoque comparativo

Oswaldo Truzzi

http://bibliotecadigital.fgv.br/ojs/index.php/reh/ article/view/2133/1272 Acesso em 22 de setembro de 2018 
cristã era uma desqualificação, pois os identificavam com o opressor muçulmano" (IBGE, 2007 p. 185). Mott explica que este sentimento decorria de um dos pilares do povo árabe, a religião. Ela complementa dizendo que "no Império Otomano de fé islâmica, as comunidades cristãs da Síria, Líbano e Egito sofreram perseguições", as quais deixaram marcas de sofrimento vividos durante o domínio turco (IBGE, 2007 p. 181).

\section{4 \\ PRIMEIRO FLUXO \\ O contexto de partida \\ e o caminho de lá para cá}

Para fins de futuro entendimento das distinções entre as primeiras trajetórias de sírios na cidade de São Paulo e as que acontecem após o ano de 2013, especificamente sobre a chegada de refugiados sírios por motivo da guerra civil na Síria, será realizada uma descrição de aspectos da história dessa imigração em relação a cidade de São Paulo, que caracterizam os motivos de partida do primeiro grupo, os percursos que realizaram até a capital paulista e, finalmente, que contextualize o ambiente de chegada. Esta estrutura será também utilizada para a imigração posterior, que acontece a partir de 2013 até o ano de 2018.

Como já mencionado, em alguns momentos, a história da imigração de sírios na cidade se cruza com a de libaneses, visto que ambos ao entrar no Brasil muitas vezes foram denominados como provenientes da mesma origem, fato que torna, em alguns aspectos, imprecisa a caracterização da imigração de um e de outro. 
Em decorrência de perseguições religiosas do Império Otomano, uma das marcas de grupo da imigração árabe foi a de ser composta predominantemente por cristãos, em sua maioria provenientes da Síria e do Líbano, enquanto que de outros pontos dominados pelo Império, como a Palestina, Egito, Turquia, Iraque e Jordânia, chegavam em quantidades bem menores. O registro da entrada de imigrantes árabes no Brasil entre os anos de 1971 e 1900 aponta para 5.400 pessoas (IBGE 2007, p. 185).

O pesquisador Oswaldo Truzzi, que se dedica ao estudo das migrações, assinala que Sírios e Libaneses foram também "incentivados sobretudo por pressões demográficas e econômicas em sua terra de origem" (2001, p.110). Isto porque começaram a surgir dificuldades para a partilha em lotes de pequenas propriedades rurais de terra arável. Haviam chegado ao limite de dividi-los entre os herdeiros e, consequentemente, emergiu a inviabilidade de suprir as necessidades de sustento de novas famílias. Para Mott, "a condição de pequenos proprietários nos seus países de origem também teve reflexos nas escolhas profissionais que fariam no Brasil (IBGE 2007, p. 185). A vivência como proprietários, mais do que como agricultores, será uma chave de decisão no curso que tomarão quando chegarem ao Brasil.

Após adquirirem seus documentos e custearem suas despesas de passagens, que eram mediadas por agências italianas, gregas ou francesas de navegação, os migrantes árabes as vezes tinham que esperar alguns meses em portos do mediterrâneo por uma conexão que os levassem para os seus destinos, a América do Norte (Estados Unidos da América) ou América do Sul (São Paulo, Rio de Janeiro ou Buenos Aires). Para alguns, aportar na América do Sul não fazia parte de seus planos, mas acabou sendo um desfecho de viagem. Muitos foram enganados pelas agências, que lhes diziam que se tratava de uma única América (IBGE 2007, p. 185 -187). Em parte, essas 
situações eram decorrentes da autonomia que o migrante árabe tinha, segundo Truzzi, por não terem sua imigração subsidiada "aqueles que haviam tomado a decisão de emigrar o faziam por conta própria", o que os tornava "muito sujeitos à ação de intermediários que exerciam o tráfico de embarques clandestinos" (2001, p 113)

A descrição distorcida e ao mesmo tempo generalista da América fez surgir entre alguns imigrantes a concepção de uma América grosseira, que de acordo com Truzzi, "simplificava sua geografia, encurtando distâncias entre cidades, regiões e países". Esta ideia de América pode ser percebida pelo relato do autor libanês Mikhail Naimy, em sua autobiografia, Uma infância no Líbano (apud TRUZZI 2001, p. 112):

Quase todos perguntavam a meu pai sobre notícias de algum parente na América. Uma mãe indagava a respeito de seu filho no Equador, uma esposa sobre seu marido na Argentina, um irmão sobre seu irmão nas Filipinas - inconscientes da distância entre estes lugares e a Califórnia, onde meu pai havia estado. Com exceção de poucos, toda essa boa gente não fazia nenhuma distinção entre uma parte das Américas e outra - tudo era apenas uma "Merica". Alguns poucos referiam-se à Nova York, significando os Estados Unidos como um todo, e ao Brasil, designando toda a América do Sul. Daí inferiam que alguém em Nova York deveria ter conhecimento de todos os seus conterrâneos nos Estados Unidos, e alguém no Brasil deveria ter contato com todos aqueles rumados para a América do Sul e para a América Central.

Parte dos que emigraram, pretendia chegar a um ambiente lhes descrito como os Estados Unidos da América, não como o do Brasil, Argentina e outros países da América do Sul. Pretendiam chegar a um ambiente de crescimento comercial e industrial, e não de um que via o imigrante como um trabalhador rural. 
Desse modo chegaram ao Brasil muitos dos árabes da primeira leva de imigração, homens, solteiros, sem domínio de seus percursos até o destino, como também, sobre ele pouco ou nada saber. Para eles, a saída de uma situação insustentável em seus países rumo as oportunidades que a América oferecia, tornava pouco relevante a qual delas exatamente se aportava. Vinham com o desejo de construir capital para, então, retornar.

\section{5}

\section{A CHEGADA, \\ A ACOMODAÇÃO \\ E AS HERANÇAS}

Do ponto de vista de estratificação social, o imigrante sírio-libanês chega ao Brasil com características distintas dos muitos dos imigrantes que os antecederam. Eles chegaram por meios próprios, pagaram por suas passagens e estadia. Não vieram sob uma política de governo que impunha o tipo de trabalho disponível e empregador. Por conta a disso, chegam com liberdade para rechaçarem o que acreditam não lhes convir. Sob esta condição, boa parte dos que aportaram nos estados do Rio de Janeiro e de São Paulo, não aceitaram se tornar trabalhadores da agricultura.

Segundo Mott, "a miséria da população rural e o sistema de compra vinculado ao proprietário da terra fizeram com que muitos repelissem a possibilidade de se ocuparem na agricultura" (IBGE 2007, p. 187), embora estivessem familiarizados com este tipo de trabalho em seus países. Ao 


\begin{tabular}{lrrr}
$\begin{array}{lrr}\text { UNIDADES DA } \\
\text { FEDERAÇÃO }\end{array}$ & 1920 & $\mathbf{1 9 4 0}$ \\
\hline Brasil & $\mathbf{5 0 3 3 7}$ & $\mathbf{4 8 9 7 0}$ \\
\hline Bahia & 1206 & 947 \\
Minas Gerais & 8684 & 5902 \\
Rio de Janeiro & 9321 & 9051 \\
São Paulo & 19285 & $\mathbf{2 4} 084$ \\
Rio Grande do Sul & 2656 & 1093 \\
Outros & 9185 & 7893 \\
\hline
\end{tabular}

Distribuição de imigrantes árabes em território brasileiro

Sinopse do recenseamento realizado em $1^{\circ}$ de setembro de 1920: população do Brasil. Rio de Janeiro: Diretoria Geral de Estatística, 1924; Censo demográfico 1940. Rio de Janeiro: IBGE, 1950; Em, A imigração árabe em Goiás: 18801970. Tese (Doutorado em História) Universidade de São Paulo, 1996. Eliana Prudente Nunes.

Mascate Mercador ambulante que percorre as ruas e estradas a vender objetos manufaturados, tecidos, jóias, etc. Fonte: https://pt.wikipedia.org/wiki/Caixeiro-viajante Acesso em 18 de outubro de 2018 verem as condições dos imigrantes que lhes precederam, italianos, portugueses e japoneses, o tipo de moradia desses imigrantes vivendo em pequenas casas de barro com cobertura de palha, de tamanho insuficiente para a quantidade de pessoas de cada família, além de uma condição de trabalho que pouco possibilitava uma independência, porque não raro, o imigrante estava sempre em dívida com o patrão, a decisão desses novos imigrantes foi por tentar outras possibilidades de sobrevivência na cidade ao invés do campo.

Segundo tabela, na qual se apresenta a distribuição de sírios e libaneses por alguns estados brasileiros, se observa não somente a maior concentração deles no estado de São Paulo, como também, o aumento da população entre os anos de 1920 e 1940. Esse crescimento em parte se deve a ocorrência de um reassentamento decorrente de possibilidades de crescimento econômico que o estado prometia, assim como da chegada de novos imigrantes, que vinham atraídos pelas histórias de prosperidade dos que no estado de São Paulo já estavam. Uma característica da imigração pós primeira leva é que esta se organiza e reorganiza em rede de contatos pessoais, onde está presente a narrativa: eu imigro, depois eu trago meu irmão, minha esposa, meu amigo etc. Após a ocorrência dessa conformação de fluxos, a rede se estabelece e tende a crescer.

A possibilidade de criar influências sem a necessidade de passar pela perspectiva econômica, sírios e libaneses, avessos ao trabalho na lavoura, fizeram emergir um novo tipo de estrutura de trabalho, a de um novo tipo de comércio ambulante. Eles se dedicaram a venda de produtos como bijuterias, tecidos, roupas, objetos de armarinho, roupas de cama entre outros produtos possíveis de serem transportados para lugares onde não havia sua comercialização. Realizavam assim o trabalho de masca$\mathrm{te}^{21}$, anteriormente exercido por portugueses e italianos. Mas segundo Mott, "a mascateação, que se tornaria uma 
marca registrada da imigração árabe, foi completamente alterada pelos recém-chegados" (IBGE 2007, p. 188).

Os novos mascates transformaram o comércio ambulante pelo seu modo de negociar as vendas. Diferentes dos portugueses, que não ofereciam nenhum tipo de facilidade para os consumidores, e dos italianos que não traziam novidades e deixaram de ser atraentes, os mascates árabes apresentavam produtos novos. No varejo, introduziram práticas inovadoras de vendas, como a "redefinição das condições de lucro, alta rotatividade e alta quantidade de mercadorias vendidas, promoções e liquidações e o interesse pelo consumidor" (IBGE 2007, p. 189). Práticas que os caracterizam como "criadores do comércio popular no Brasil" (2007, p.187).

Do modo de fazer comércio dos novos mascates, emergiu uma rede de trabalhadores que faziam com que mercadorias encontradas somente nas metrópoles chegassem até os que trabalhavam nas lavouras. Os novos imigrantes levavam até eles, novidades em diversos seguimentos. De acordo com Truzzi, a mascateação de sírios e libaneses se constituiu em uma rede familiar e de conterrâneos e "foi vista como capaz de propiciar um rápido retorno econômico" (1992, p. 111).

Com o sucesso que obtiveram, mascates sírios e libaneses expandiram seus negócios e, de vendedores de porta em porta, passaram a proprietários de lojas e delas, a donos de fábricas. Assim, a rede de comercialização de produtos se expandiu e passou a ter outros centros, como o de produção e distribuição, passando eles a atuarem além do varejo, no atacado, como fornecedores. Para Truzzi, o sucesso que obtiveram no comércio se baseou no modo com os elementos da rede se relacionavam. Suas conexões se configuravam a partir de uma cadeia que tinha inicio na chamada e acolhimento de outros imigrantes, oferecendo a eles possibilidades de aquisição de mercado-
Imagem capturada do vídeo: Imigração árabe no Brasil https://www.youtube.com/watch?v=Be8gjeTcQmg Acesso em 13 de junho de 2018 




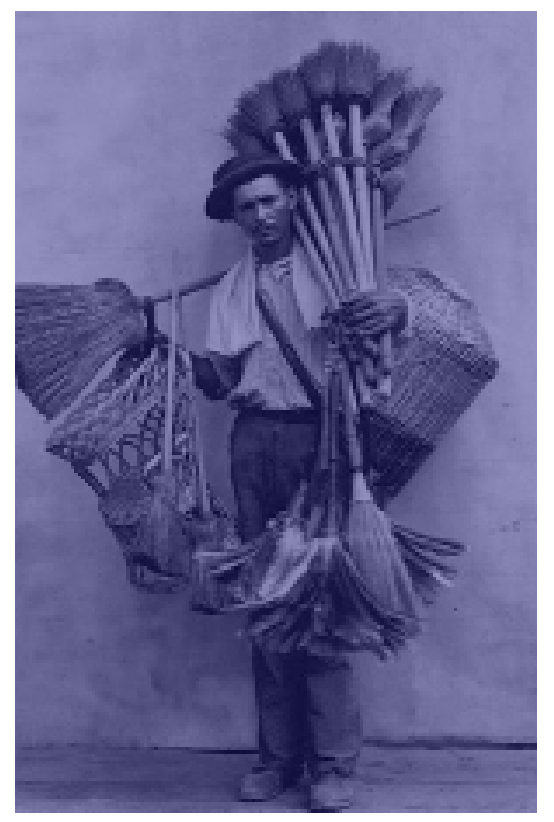

Mascate italiano vendedor de vassouras no Brasil. https://imigracaohistorica.com/fotos/ Acesso em 15 de junho de 2018

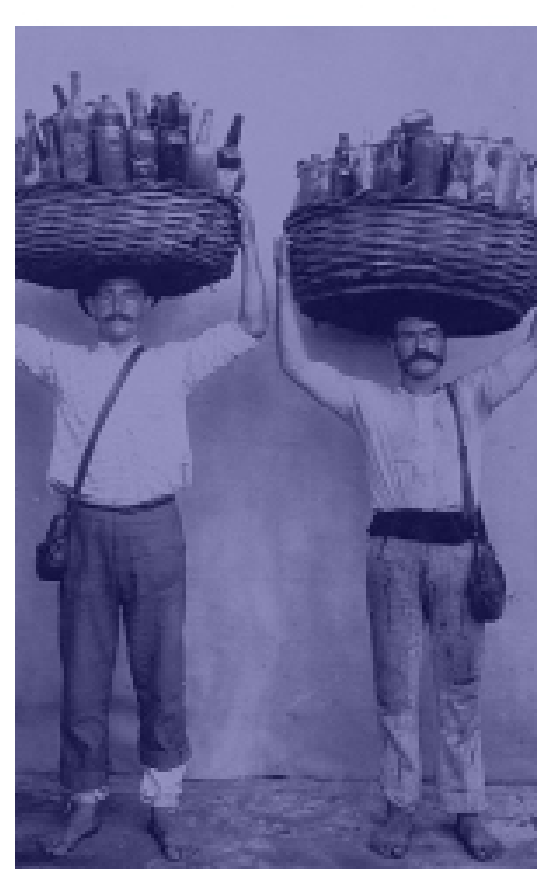

Mascates italianos vendedores de bebidas no Brasil. https://imigracaohistorica.com/fotos/ Acesso em 15 de junho de 2018 rias por meio da concessão de crédito, assistência no início do negócio até que se tornassem mascates, lojistas, do varejo ou atacado e industriais. Uma rede que se conformava por um conjunto de interesses complementares.

Entre as condições que contribuíram para tomassem um rumo distinto ao dos trabalhadores rurais, está a de sua chegada ao Brasil. Vieram por conta própria, diferentemente de portugueses, italianos e outros que chegaram por meio da imigração subsidiada. Diferentemente deles, os novos imigrantes custeavam suas despesas de documentação, passagem e hospedagem e isso já lhes dava uma condição de chegada no ambiente de destino com uma certa autonomia para tentar novas formas de a ele se adaptar.

Ainda de acordo com Mott, outro fator estava relacionado às suas experiências passadas. "A condição de pequenos proprietários nos seus países de origem também teve reflexos nas escolhas profissionais que fariam no Brasil" (MOT'T, 2007, p. 183). Ou seja, sabiam conduzir um pequeno negócio e não estavam acostumados a serem comandados por um patrão. Assim, surge um novo perfil de imigrante no território brasileiro, não mais afeito ao trabalho na lavoura e submisso a regras impostas por um patrão.

O desejo da maior parte de sírios e libaneses de que o Brasil fosse apenas um lugar de permanência temporária, cuja finalidade era apenas a de acumular capital para então retornar a sua terra natal, se transformou em um projeto maior, do qual faziam parte seus familiares e outros que, com eles, mantinham algum laço de amizade. Pessoas que vieram para o Brasil e contribuíram para o crescimento da imigração árabe e de uma nova cultura. 


\section{6}

\section{UM MUNDO ÁRABE DENTRO DA CIDADE DE SÃO PAULO}

Após a decisão de permanecer, que boa parte dos imigrantes árabes tomou ao perceber que haviam fatores favoráveis não só para ficar, mas também para trazer outros, houve muitos investimentos não somente em negócios, mas também em criar um ambiente para se viver, onde a cultura árabe pudesse ser cultivada e compartilhada. Neste sentido, sírios e libaneses e paulistas tornaram-se sujeitos em processo de troca cultural, estabelecendo uma rede de influências em mútua direção.

Por uma perspectiva econômica, contribuíram significativamente para o desenvolvimento do maior comércio de rua do Brasil, o da Rua 25 de março. Segundo Mott, esta rua se tornou um "pólo de atração” e em 1893 “já há referências a casas de comércio, sendo que 90\% dos mascates eram sírios e libaneses". Uma representatividade que cresceu e no ano de 1901, quando, “já eram mais de 500 casas comerciais na região. Seis anos depois, um levantamento indicou que de 315 firmas de sírios e libaneses, $80 \%$ eram lojas de tecidos a varejo e armarinhos." (2007, p. 186).

Com o crescimento econômico e acúmulo de capital proveniente de um conjunto de fatores favoráveis ao negócio desenvolvido por imigrantes sírios e libaneses na cidade de São Paulo, estes iniciaram algumas estratégias de for-

Loja de imigrante árabe na rua 25 de http://museudaimigracao.org.br/sobre-os-poucos-registros-para-sirios-e-libaneses-na-hospedaria-dos-imigrantes/ loja-de-imigrante-arabe-na-rua-25-de-marco_1954/ Acesso em 23 de novembro de 2018 


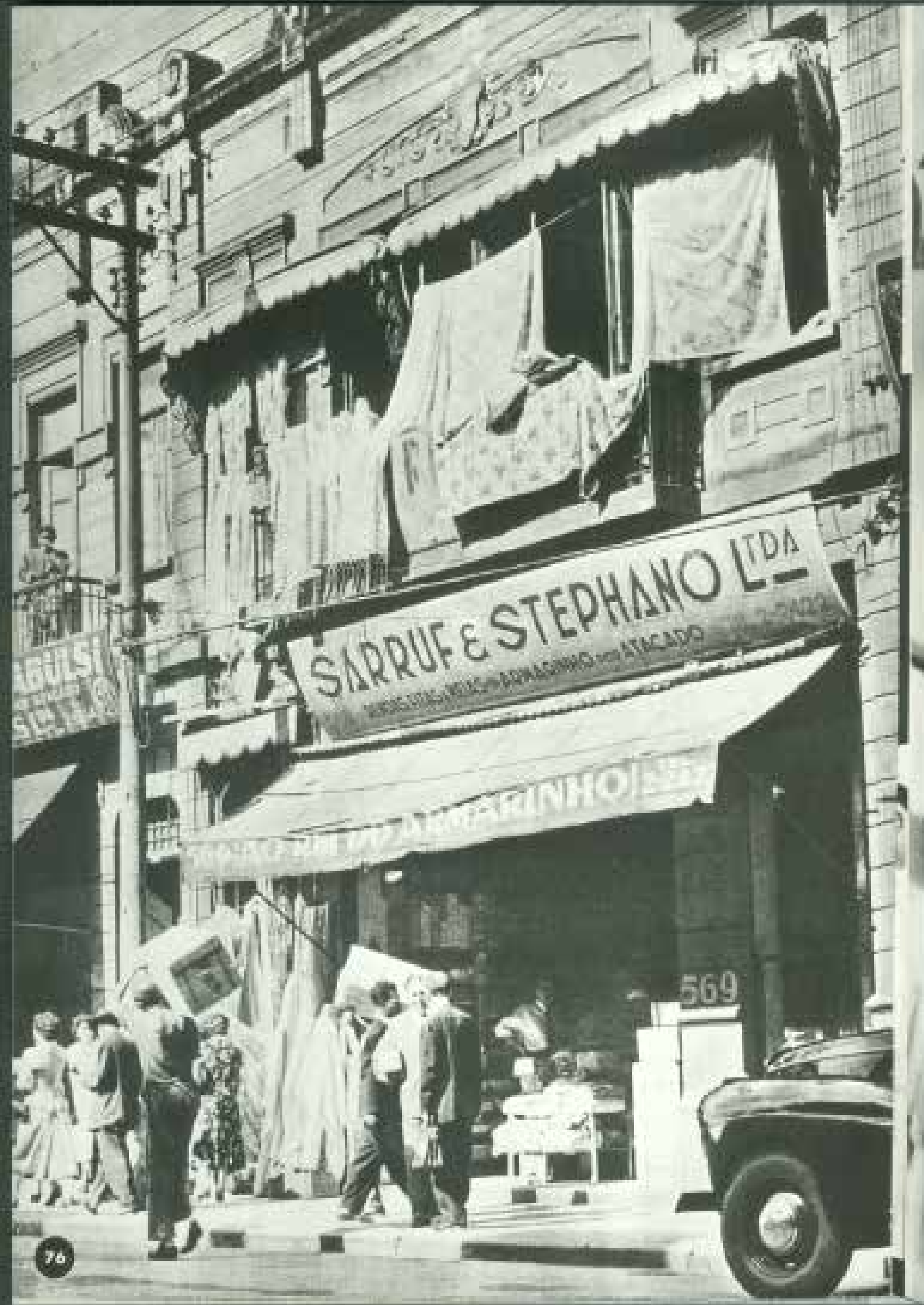



talecimento de sua comunidade e de relação com a sociedade. Assim, começaram a colocar em ação suas intenções, com o objetivo de que seus descendentes brasileiros ocupassem posições em outros contextos sociais e econômicos, além do território já conquistado: o da produção e do comércio de produtos de armarinhos e tecelagem.

Em números, o Censo Demográfico e de 1940 apresentava que filhos de árabes contabilizavam 107.074 e, segundo Quinaglia (2018), “foram esses que se dedicaram ao Ensino Superior em áreas como Direito, Medicina e Engenharia", campos profissionais que levariam ao reconhecimento social com inserção relevante. A pesquisadora complementa afirmando que "a escolaridade era vista como um investimento familiar para que a segunda geração obtivesse um diploma e se tornasse "doutores", garantindo maior mobilidade social” (2018, p. 100).

Investimentos estruturais para a educação também foram realizados. No ano de 1897 já existia uma escola de origem Sírio-Francesa (Maronita) ${ }^{22}$ na cidade de São Paulo e nos "anos seguintes foram fundados na capital paulista o Ginásio Oriental (1912), o Colégio Sírio-Brasileiro (1917), o Colégio Moderno Sírio (1919) e o Liceu São Miguel (1922)" (IBGE, 2007, p.192).

Os investimentos familiares eram direcionados tanto aos homens, quanto às mulheres, com a diferença de que os primeiros eram estimulados a seguir carreira de doutores, enquanto elas faziam cursos profissionalizantes. Truzzi destaca que, entre as décadas de 1930 e 1950, sírios e libaneses compunham o segundo grupo étnico a realizar o ensino superior nas três faculdades mais importantes: medicina, en-

igreja cristã, do rito oriental, em plena comunhão com a Sé Apostólica, ou seja, reconhece a autoridade do Papa, o líder Igreja Católica Apostólica Romana. http://www.igrejamaronita.org.br/conteudos/?e-

Fh4fDEXNQ $==$

Acesso em 14 de novembro de 2018 genharia e direito (2001, p. 117).

Além da inserção social através da educação, política e atuação profissional, os sírios trataram de criar estruturas de preservação de sua cultura e religião. Uma delas configurada pelo matrimônio com pessoas da mesma etnia. Des- 
de o início das imigrações, grande parte composta por homens solteiros, os casamentos eram realizados com parceiras também oriundas da terra de origem. Muitas vezes os homens regressavam para se casar e então retornar ao Brasil. O imigrante Wadih Safady, filho de um dos primeiros imigrantes árabes a chegar ao Brasil em 1887, observou em seu livro Cenas e cenários dos caminhos de minha vida (1966, p. 221), que a miscigenação era algo que os pais não admitiam, por acreditarem que para uma união ser harmoniosa deveria ocorrer entre pessoas da mesma etnia.

Truzzi, relata que em 1927 "sírios e libaneses apresentavam a segunda maior taxa de endogamia: 50,5\%, superados apenas pelos japoneses, com 63,3\% (2001, p. 136). Ele ressalta que esta estratégia de segregação significava também a manutenção de prestígio social e econômico, visto que o imigrante sírio-libanês era visto como de uma casta nobre, por ser branco e estrangeiro. "Comparados aos negros ou aos trabalhadores nativos vistos como indolentes e atrasados (os caipiras em São Paulo)", continua ele, "os imigrantes em geral eram percebidos como mais qualificados, habilidosos, dedicados e frugais, como, elementos capazes de, aos poucos, "embranquecer" a população" (2001, p. 135).

O mundo de sírios e libaneses na cidade de São Paulo se estruturou entre o desejo de criar conexões com o ambiente que the acolhia e a manutenção de sua cultura através, fundamentalmente, da língua, da gastronomia e da religião como, a rigor, acontece com imigrantes de e em outras lugares do mundo. Em termos de religião, segundo Mott, o maior contingente de imigrantes árabes era composto por cristãos, "vindos em grande parte do Líbano e da Síria" (IBGE, 2007, p. 185). De modo geral, a imigração de árabes construiu na cidade de São Paulo marcas de sua fé, manifestas na construção de igrejas, catedrais e mesquitas. 


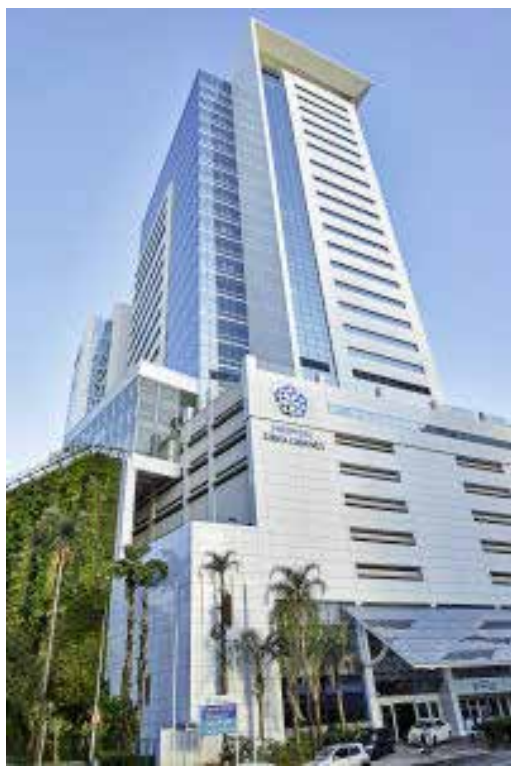

Hospital Sírio-Libanes

A instituição surgiu em 1921, quando um grupo de imigrantes da comunidade sírio-libanesa no Brasil se reuniu com o objetivo de criar um projeto que retribuísse a acolhida calorosa que receberam no país. Foi criada então a Sociedade Beneficente de Senhoras, entidade filantrópica

até hoje mantenedora da instituição.

https://www.hospitalsiriolibanes.org.br/institucional/Paginas/default.aspx

Imagem

https://abramed.sv.com.br/hospital-sirio-liba-

Acesso em 23 de novembro de 2018
Ao se observar a imigração de sírios e libaneses desde as primeiras chegadas à cidade de São Paulo, pode-se perceber que tanto eles, quanto a cidade, se transformaram em decorrência da relação estabelecida. Neste sentido, o paradigma de relação sistema-ambiente pode contribuir como arcabouço teórico para a compreensão de seus movimentos e desdobramentos. Esses processos culminaram no que viria a ser uma história significativa na existência de um e de outro, do imigrante e da cidade.

A concepção de sistema pressupõe a existência de uma fronteira definidora do que chamamos de externo e interno, e este é um dos principais aspectos da complexidade entre sistema e meio, caracterizado pela ausência de contornos e limites definidos entre ambos. Este limite é uma abstração com qual se deve lidar em estudos sobre sistemas, que ocorrem sob um modelo de interdependência e integralidade. Segundo Vasconcellos, as fronteiras não são sistemicamente concebidas como barreiras, mas sim como o "lugar de relação" ou o "lugar das trocas" entre sistema e ambiente (2015, p. 207). Morin afirma que isolá-los seria "criar in vitro um isolamento puramente determinista" (1996, p. 202), alheio à realidade do ambiente, em outras palavras, alheio à complexidade dos fenômenos do mundo.

O imigrante sírio, ao chegar no Brasil, é o estranho, com distinções culturais significativas, entendidas como o rasgo, a ruptura, o distúrbio que provocaria transformações em si e no ambiente no qual estavam se inserindo, a partir de categorias como migrantes estrangeiros e ou refugiados. Ao se traçar um paralelo entre a imigração síria e libanesa que ocorreu no Brasil com a que aconteceu nos Estados Unidos da América, para fins de entender como em um ambiente e em outro os imigrantes chegaram e se acomodaram, vê-se desdobramentos distintos. Ainda considerando Truzzi, enquanto no Brasil "o grosso da imigração síria e libanesa, a partir da última década do 
século 19, não se encontrava muito atrasado em relação ao tempo de chegada das outras etnias" (2001, p. 127), o que lhes permitiu ocupar e dominar um espaço de produção econômica pouco explorado; nos EUA chegaram sob condições contrárias, quando a mascatearia já caia em declínio sob a pressão da produção industrial. Truzzi destaca que,

\begin{abstract}
Apesar de sírios e libaneses terem chegado aos dois países aproximadamente na mesma época, podemos afirmar que o papel saliente que tiveram no Brasil, especificamente em São Paulo, se deveu em grande medida ao pioneirismo de suas atividades comerciais, à sua inserção nitidamente urbana e desconcentrada ao longo de inúmeras cidades do interior, e à circunstância de terem chegado, mesmo que inadvertidamente, ao lugar certo no tempo certo.” (2001, p. 136)
\end{abstract}

Desse modo, esses sujeitos encontraram no Brasil, ainda que com algumas dificuldades de assimilação, um ambiente que os acolheu como elementos favoráveis, ao contrário dos EUA, onde as suas atividades comerciais não encontraram lugar e ainda enfrentavam novos processos oriundos da produção industrial.

Uma das principais características da relação entre sistema e ambiente, para Luhmann (1995), é que nesta relação se "pressupõe que o sistema desenvolva uma elevada indiferença em relação ao meio, e que, nesse sentido, este último careça de significado para o sistema" (1995, p.63), uma vez que não é o ambiente/meio que determina sob quais critérios ocorrem as intercâmbios, mas sim o sistema. Essa indiferença de um em relação ao outro é agenciada pelas ações do Acoplamento Estrutural, cujo objetivo é o de selecionar ocorrências significativas no ambiente que estabeleçam sobre o sistema algum tipo de afetação. Luhmann explica que o acoplamento estrutural é "a linha de demarcação que o divide com o ambiente" (1995, p. 132).
Mesquita Brasil

Primeiro templo muçulmano do país, na Avenida do Estado - Cambuci https://vejasp.abril.com.br/cidades/roteiro-cultura-oriental/ Acesso em 06 de dezembro de 2018 



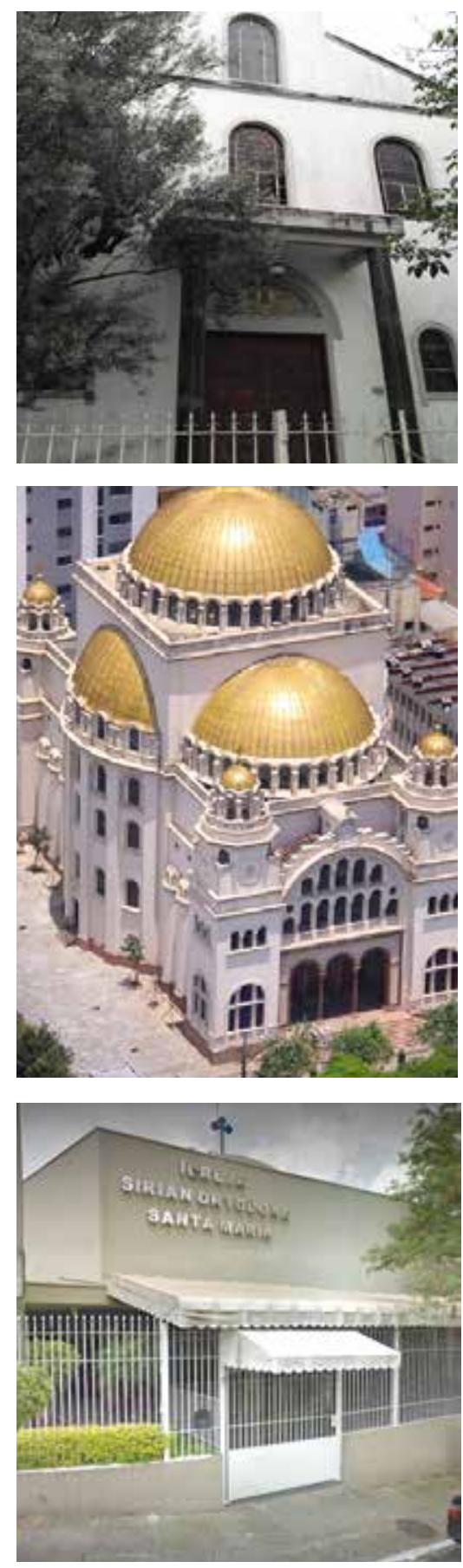

Igreja Sirian Ortodoxa São João do Brazil

Catedral Metropolitana Ortodoxa Templo religioso localizado na Avenida Vergueiro em São Paulo https://brpinterest.com/ pin/394979829798577385/? p=true

Igreja Sirian Ortodoxa Santa Maria

Acesso em 06 de dezembro de 2018

No caso da relação entre imigrantes sírios e o ambiente de chegada, essa linha de demarcação lhes proporcionou a incorporação de alguns elementos da cultura e por outro lado, rechaçou o que para eles seria uma destruição de si. O pensamento de Luhmann (1995) sobre a relação sistema e meio se refere ao fato de que pessoas, por uma perspectiva sistêmica, realizam trocas com o meio sob um certo controle do que lhes convém para crescer e se adaptar, de modo que sua integridade seja mantida.

Quando sírios criam estratégias para que sua cultura se mantenha, pela endogamia, religião, língua ou pela culinária etc., há uma ação de negação de uma influência presente no meio que pode destruir o que para eles é fundamental manter como identidade. Neste sentido, sistemas em relação ao meio necessitam desenvolver "uma disposição especial para a complexidade, no sentido de ignorar, rechaçar, criar indiferenças, enclausurar-se em si mesmo" (LUHMANN, 1995, p.179). 
118 FAUUSP TESE DE DOUTORADO MIGRAÇÃO, COMPLEXIDADE E DESIGN 
3

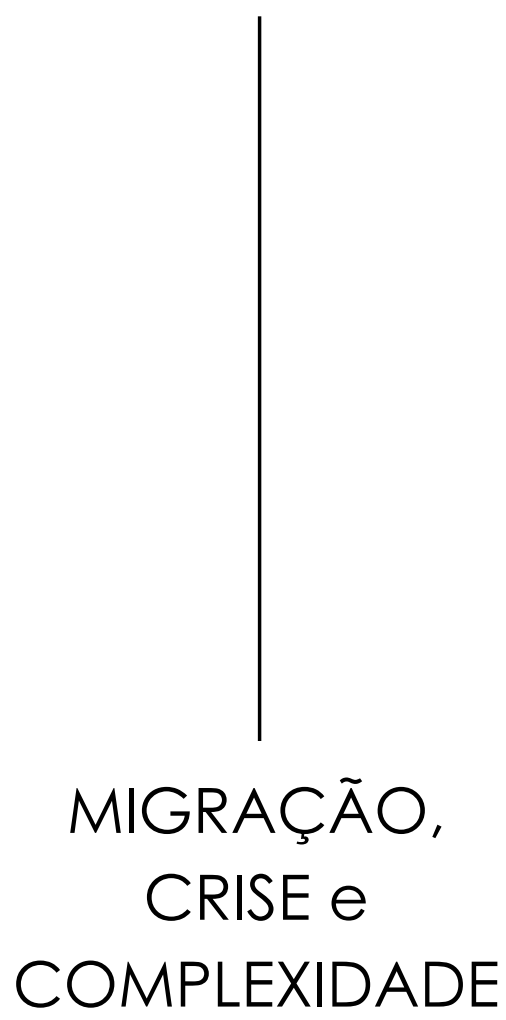





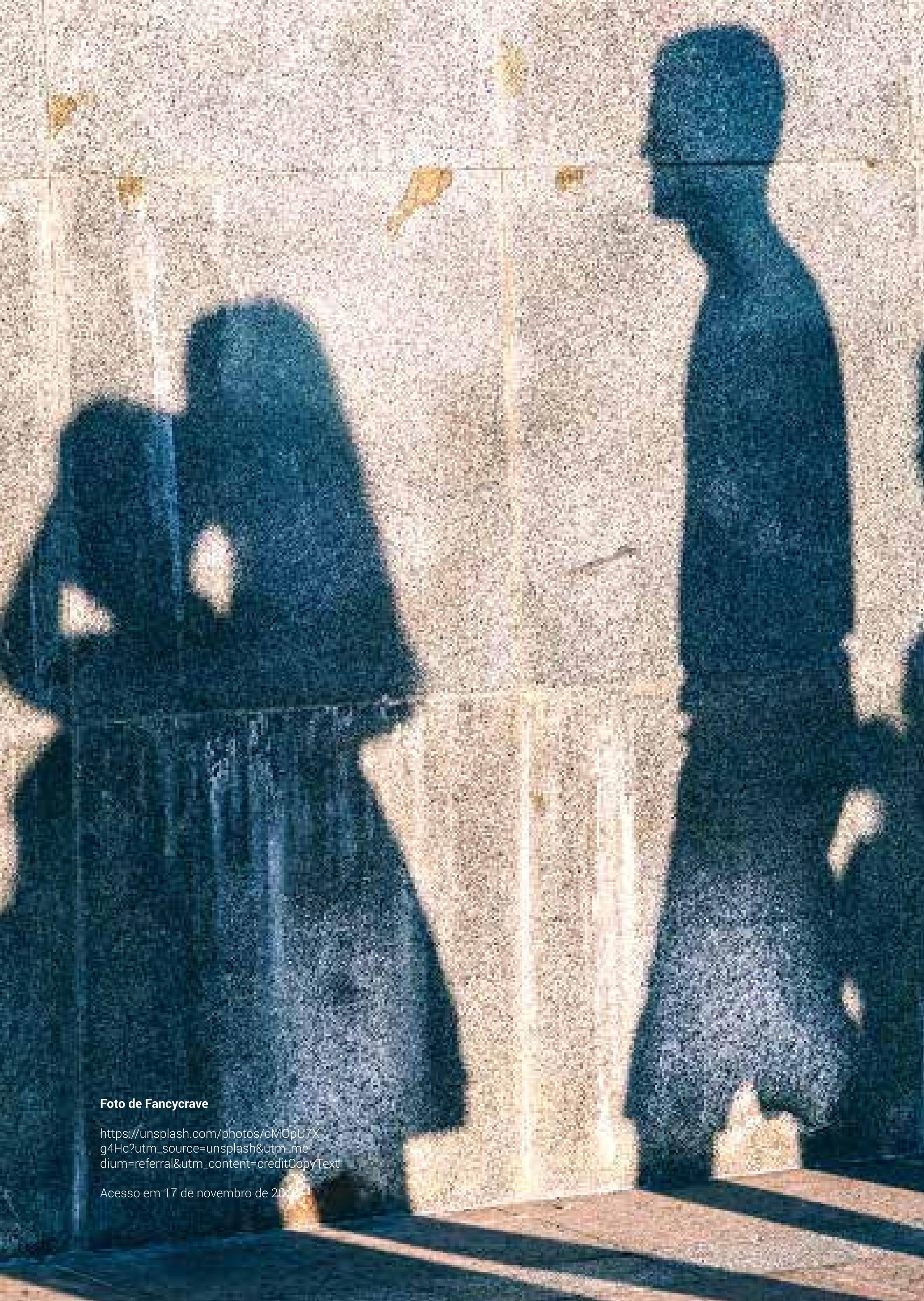


O conceito de crise, pela perspectiva da teoria da complexidade, demanda por um modo de pensar sistêmico posto sobre problemas complexos cujas características, de acordo com Edgar Morin (Fronteiras do Pensamento, 2013), os tornam difíceis de serem concebidos e entendidos. $\mathrm{O}$ fenômeno da imigração/refúgio por estar inserido dentro de um ambiente global e de globalização se estrutura por processos que por mais demorados que sejam pela perspectiva dos diretamente envolvidos (imigrante, familia, amigos etc.), ainda assim são acelerados e interligados com outros fenômenos também de complexidade tamanha.

Questões humanitárias, condições de entrada e saída, diversidade linguística, atualização de aparatos legais, inserção no trabalho são apenas alguns aspectos objetivos diante dos quais os envolvidos estão expostos. Se forem somadas as questões subjetivas que envolvem rejeição, preconceito, disputas de todos os tipos e sentimentos extremos, o descompasso entre o conhecimento e o enfrentamento da crise torna-se quase impossível. A complexidade do problema exige, portanto, que se saiba lidar com temporalidades, espaços, sujeitos e dinâmicas diversas, que se desdobram pelas condições dadas pela trama de interconexões entre os envolvidos direta ou indiretamente.

Deparar-se com situações em curso requer, ainda de acordo com Morin (2013), uma mudança no modo de pensar e agir, por invocar um práxis difícil, mas necessária de não divisão ou repartição entre o que está em relação. Crises, é senso comum, podem se desdobrar em situações tanto positivas, quanto negativas, sem que isto signifique incontinenti uma dessas opções. Crises são rupturas, rasgos que ocorrem sobre estados de ordem aparente, qualificados como contextos estáveis, no sentido de estarem dentro de uma regularidade esperada. Em entrevista a jornalista Djénane Kareh Tager (2010), o sociólogo francês traz o entendimento de que crise não é "o contrário do desenvolvimento, mas a própria forma deste” (2010, p. 57). 
O desenvolvimento ocorre por movimentos que transformam e que modificam seus estados, como uma espécie de metamorfose rumo a superação, ainda que isto não signifique uma solução definitiva em direção a uma estabilidade tranquila e imune a novas crises.

Entre tantas crises que emergem desse ambiente global e interconectado, o fenômeno da migração forçada tem diversos elementos e se configura como o que se denomina de problemas capciosos, como uma crise que se desdobra em outras crises que se reforçam reciprocamente e que podem ser identificadas a partir de problemas como a escassez de alimento, a precariedade de moradia, o surgimento de doenças físicas e emocionais, conflitos políticos, econômicos e sociais etc. Essas crises, segundo o sociólogo Jean-Marc Salmon (2012), "se respaldam mutuamente. Embora tenham características e temporalidades diferentes, podem alimentar umas às outras, por feedbacks positivos, ou podem, por feedbacks negativos, produzir efeitos ioiô: quando uma sobe a outra baixa, e vice-versa."(in LENA; NASCIMENTO, 2012, p.389) Tais conceitos da Cibernética indicam mecanismos de regulação que buscam manter a estabilidade de um sistema. Sob essa noção de sistema, ele complementa dizendo que são crises que "se fundem em uma crise complexa, uma policrise. Interagem como num sistema" (2012, p.389).

Compartilhando do mesmo modo de pensar sistêmico de Salmon, o antropólogo Michel Agier (2015) estabelece um olhar sobre o fenômeno das migrações como crises humanitárias, e diz que a crise se caracteriza como tal quando um determinado acontecimento rompe com a estabilidade da pessoa, quando uma informação, o dado novo coloca em questão a necessidade de uma tomada de decisão de impacto profundo em sua vida. Sair de sua casa, de sua cidade, de sua rotina e de suas relações pessoais é um processo de desestabilização com potência para a emergência de policrises. Encontrar um refúgio, 
integrar-se ao novo local e, caso isso não aconteça, reassentar-se em outro são processos de enfrentamento que caracterizam o início de um longo caminho.

À chegada, novas crises colocarão em questão sua habilidade para integrar-se a nova cultura. Fatores como idade, aparência, traços étnicos, hábitos, crenças, alimentação, regras, condição econômica tanto de saída como de chegada, experiência de deslocamento e de acolhimento, elementos subjetivos e ou emocionais, domínio da língua, entendimento dos valores e símbolos e outros mais pedem não só por um olhar que consiga capturar a heterogeneidade dessas situações, quanto a capacidade de entender o que as tornam inter-relacionadas, múltiplas e variadas.

As noções de Morin, Salmon, Agier e Luhmann sobre complexidade e sistemas se juntam nessa segunda parte do capítulo às dos pensadores da Teoria Geral de Sistemas e áreas vinculadas para então contribuírem em uma reflexão sobre o segundo fluxo de imigração síria na cidade de São Paulo, caracterizada como um novo fluxo, com outros elementos, em um outro ambiente, do qual emergem outras situações e demandas. O fenômeno aqui é outro, ainda que traga para a cena, nomeadamente a mesma cidade, São Paulo, e o mesmo povo, o Sírio. Entende-se que dentro desse outro há uma tradição que atualiza a cidade, seus habitantes assim como os próprios imigrantes.

Entre os fluxos de migração síria que ocorreram desde um passado secular até o dos dias atuais, muito se transformou no mundo e nas pessoas, assim, um evento do passado, que aparentemente volta a ocorrer no presente, inevitavelmente se manifestará sob novas feições e modos de organização e em alguns deles, há de ocorrer também, o retorno de algumas características padrão, que mesmo com o passar do tempo se mantém e são passiveis de transformação somente a partir de um processo recursivo de atualização. 
Com o objetivo de refletir sobre fenômenos complexos a partir da imigração síria na cidade de São Paulo, a discussão será apresentada e articulada desde os contextos de saída, chegada e acomodação. Levando-se em consideração o que acontece em relação ao fluxo anterior, mas sob novas conjecturas: a origem, o acontecimento de expulsão, o indivíduo, o lugar de chegada e o ambiente que a todos envolve.

Por uma visão macro da migração de sírios no contemporâneo, é imprescindível registrar que ela acontece em um ambiente global altamente interconectado. De um processo de relações pessoais onde a predominância do contato presencial era o vértice de conexão entre um e outro, vive-se atualmente em um mundo onde muitas vezes o contato físico é o que menos importa, valendo mais, os interesses em comum, numa perspectiva, pode-se afirmar, algorítmica. Por uma visão de rede, o mundo de hoje em termos de comunicação interpessoal se apresenta de forma distinta em relação a como ocorria durante o primeiro fluxo de imigrantes sírios. As possibilidades e condições de comunicação se ampliaram, além do possível no século passado, a partir de cartas, telefonemas e/ ou encontros pessoais.

As tecnologias de comunicação e informação digital passaram a ser mediadoras prioritárias e principais da comunicação síncrona ou assíncrona, dentro de uma organização configurada em rede e a partir de um design digital que consegue projetar a alcance espacial e temporal dos sujeitos em comunicação. Assim, além de redes de contato com centros bem definidos e das que ocorrem com múltiplos centros, como no grupo familiares, no trabalho, nos grupos de interesse, de estudo, ongs etc., existem também, as relações que se configuram de modo distribuído, com seus nós equivalentes e com pesos iguais. 
No mundo contemporâneo, salvo algumas exceções, a probabilidade que se aporte em algum lugar sem que antes se tenha algum conhecimento sobre ele é algo cada vez mais raro. Com o surgimento de tecnologias de geolocalização é factível que se conheça de antemão não somente alguns pontos de interesse do lugar de destino, mas que se tenha uma visão privilegiada em relação até mesmo à população local. Esse é um elemento de profunda diferenciação do imigrante contemporâneo daquele que se deslocava nos fluxos anteriores. Há atualmente um novo modo de viver, de se relacionar e de se deslocar. Nele, os acontecimentos e as informações são acessados de forma mais rápida e mais abrangente o que reduz as barreiras comunicativas e amplia o cenário de interconexão. Isto torna tudo, ou quase tudo, diferente.

\section{1}

\section{ACONTECIMENTO}

No início de um fenômeno reside um acontecimento. Um tornado, por exemplo, se forma a partir do encontro de uma frente fria com ar quente e instável. O encontro é o acontecimento que favorece o surgimento de uma tempestade que se desdobra no fenômeno tornado. E assim, tantos outros emergem.

Segundo Luhmann, acontecimentos "são elementos que se fixam pontualmente no tempo, ocorrendo apenas uma vez, e somente no lapso mínimo necessário para sua aparição"(1995, p. 140). O caráter de singularidade de um acontecimento é associado ao conceito de informação. $\mathrm{O}$ acontecimento 


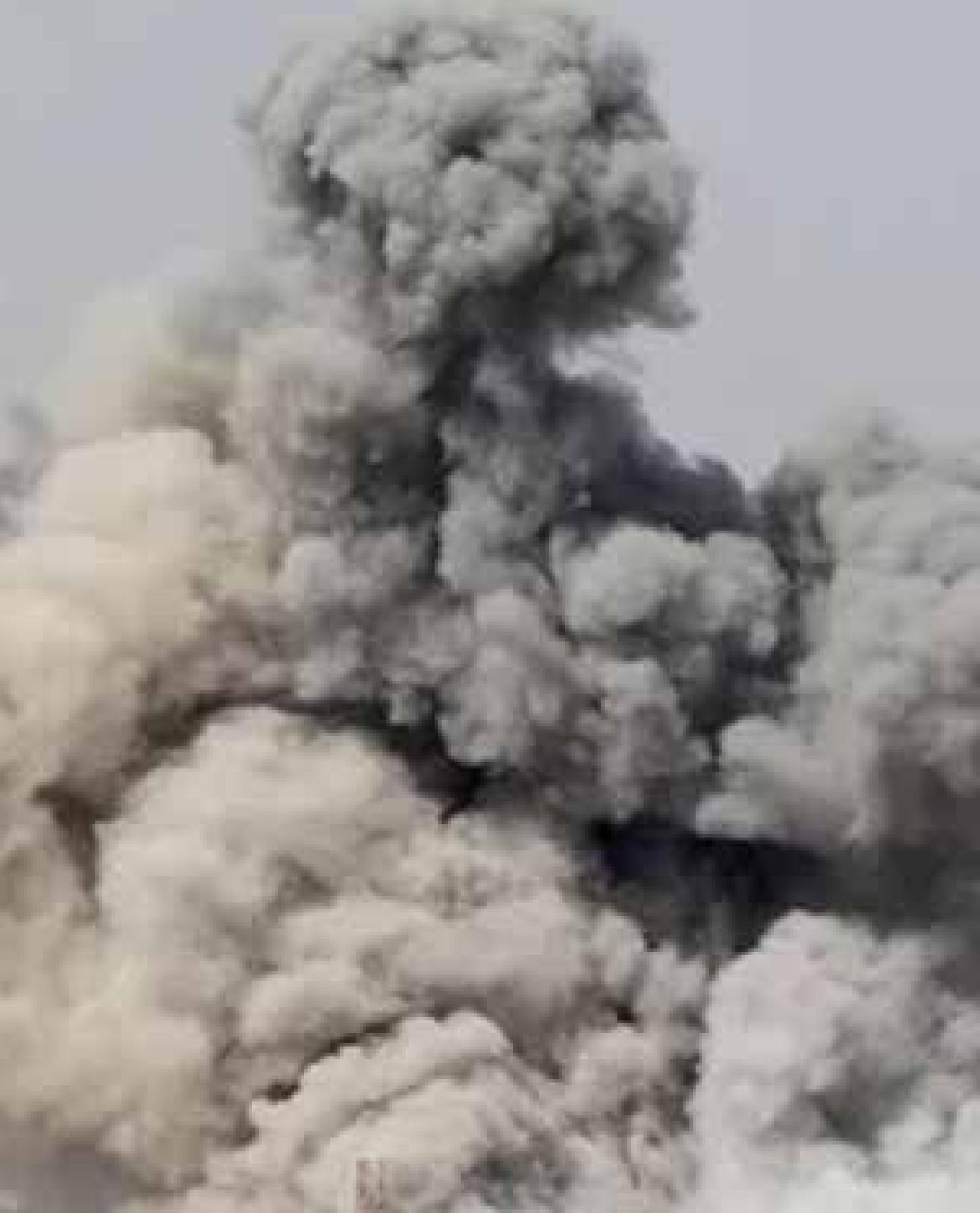

= 
lados: a) o caráter de surpresa que traz implícita a informação; b) o fato de que a surpresa só existe se as expectativas já estiverem pressupostas no sistema, e se já estiver delimitada a margem de possibilidades dentro da qual a informação pode optar. Assim, informação é seleção que só acontece uma vez, na escala das possibilidades, e que, quando é repetida, perde o caráter de surpresa.” (LUHMANN, 1995, p.141)

O sentido de acontecimento associado ao de informação adotado por Luhmann, está relacionado ao que dentro da Teoria dos Sistemas tem o papel de promover o equilíbrio, ou seja, ele designa como informação "um acontecimento que seleciona estados do sistema" (1995, p.141). Assim como o faz os sistemas cibernéticos com seus feedbacks positivos e negativos a partir de um acontecimento que chega como informação ou repetição. Há nesta concepção uma relação entre aquele que chega - o acontecimento, o processamento do novo - após uma seleção baseada em pressupostos do sistema, e por fim, a emergência do novo, que se conforma dentro de uma escala de possibilidades.

Esse determinismo, denominado de estrutural em sistemas, que Luhmann traz para o universo da sociologia é também incorporado pelos biólogos chilenos Francisco Varela e Humberto Maturana (1974), após seus estudos sobre a organização circular dos seres vivos, pesquisa que resultou na elaboração da teoria da autopoiese, na qual abordam um tipo de sistema vivo, os autopoiéticos, como organismos que não sofrem influências do ambiente sobre suas estruturas por serem auto referenciados, qualidade a partir da qual se reestruturam.

O que se define por acoplamento estrutural atua como uma intersecção entre sistema e meio de modo a realizar 
a seleção de estímulos que irão de algum modo afetar o sistema. Luhmann, referindo-se a este conceito diz que " $\mathrm{O}$ meio só pode influir causalmente em um sistema no plano da destruição, e não no sentido da determinação de seus estados internos" (1995, p. 130).

Dessas concepções pode se concluir que um acontecimento, tanto no nível social, quanto no biológico, afetará ou não um sistema a partir do que este, estruturalmente, entende como um dado novo, uma informação, e é o sistema, e não o acontecimento, que irá determinar quais ações serão empreendidas. Vale ressaltar que é possível que transformações ocorram, mas somente sob os fatores de tempo e recorrência.

\section{2}

\section{UM OUTRO ACONTECIMENTO, UMA NOVA CRISE, UMA OUTRA MIGRAÇÃO}

Enquanto o acontecimento do primeiro fluxo trouxe para o Brasil um grupo de imigrantes com características homogêneas: homens, jovens e casados, o da crise atual possui uma amplitude que abrange todas as representatividades do universo social. Agora estão também mulheres, crianças, idosos, profissionais liberais, empresários e trabalhadores. A crise atual da Síria é de ordem humanitária, ou seja, é uma crise que atinge a todos, e que os coloca em situação de emergência, que invariavelmente traz como imperativo sair como única possibilidade de continuar vivo. 
Este é o tipo de crise vivida pela Síria nesta primeira metade do século 21. Uma crise que eclodiu em meados de dezembro de 2010, com os movimentos da Primavera Árabe, denominação a uma série de protestos que ocorreram em mais de dez países do Oriente Médio e Norte da África, decorrentes da insatisfação popular com a política econômica e o autoritarismo de governos árabes. A geógrafa Shadia Husseini de Araújo ${ }^{23}$ (2013), chama atenção para o fato de que a Primavera Árabe, "não deve ser compreendida como um fenômeno em si. Pelo contrário. Trata-se de um significante (e não de um significado), de um nome para uma série de acontecimentos que são extremamente heterogêneos e contraditórios" (2013, p. 43). Esta concepção reforça o entendimento de que dessa série de acontecimentos decorre uma sucessão de eventos que, postos em relação, transformaram-se, no caso da Síria, no fenômeno da migração em larga escala.

Após um pouco mais de oitos anos do que foi considerado o estopim da Primavera Árabe - a autoimolação do vendedor tunisiano Mohammed Bouazizi ${ }^{24}$ - os resultados do movimento em cada país foram distintos, mesmo que muitas das motivações tenham sido compartilhadas. Cada ambiente agiu e reagiu de acordo com as características dos povos, dos governos e de interesses externos.

Na Síria, as manifestações populares tiveram início em 26 de janeiro de 2011, progredindo para um conflito armado, dois meses depois, entre governo e civis se prolongando e ampliando por todo o seu território. A duração do conflito se estende e parece estar longe de ter um fim. Os desdobramentos desses protestos conformaram em um fenômeno multifacetado, complexo e global. Neste sentido, é imprescindível que se conheça seu desenvolvimento, especificamente dentro do país ou, de modo mais abrangente, o ambiente onde emergiu.

O teórico organizacional Gareth Morgan (2002) explica que existem acontecimentos capazes de provocar mudan-

\section{Artigo: o "islã” como força política na "primavera árabe": uma perspectiva da teoria do discurso \\ Shadia Husseini de Araújo https://revistas.ufpr.br/historia/article/ view/33895 \\ Acesso em 15 de setembro de 2018}

\footnotetext{
24 Mohammed Bouazizi, de 26 anos, ateou fogo no próprio corpo em protesto por ter tido toda sua mercadoria confiscada por um fiscal do governo.
} 
MAPA: representação do pós Primavera Baseado em https://en504asp.wordpress. com/2014/08/07/welcome-to-the-arab-spring-project/ Acesso em 15 de setembro de 2018 ças que passam de um estado de controle ao de perda de controle de modo rápido e acelerado. Ele recorre ao efeito borboleta, uma expressão da Teoria do Caos - que descreve como a sensibilidade de um sistema a condições iniciais pode promover resultados imprevistos -, para dizer que muitos aspectos da vida social são suscetíveis a esse tipo de ocorrência. Por esta concepção, Morgan diferencia sistemas simples de sistemas complexos. Caracteriza os complexos como aqueles que possuem potencial para a ocorrência de processos amplificadores de desvios, os quais podem ser "de muito baixa probabilidade, como por exemplo, que uma determinada árvore cresça em uma fenda de uma rocha ou que uma cidade se desenvolva num determinado ponto de uma planície" (2002, p. 275).

Fenômenos complexos como o do deslocamento da população síria ao redor do mundo não podem ser compreendidos a partir de uma única causa, mas sim de fatores interdependentes, em âmbito coletivo e individual.

É impossível conhecer o todo por suas partes, concluem os teóricos de sistemas. Tampouco se conhece um fenômeno sem o seu ambiente. Assim, é imprescindível que

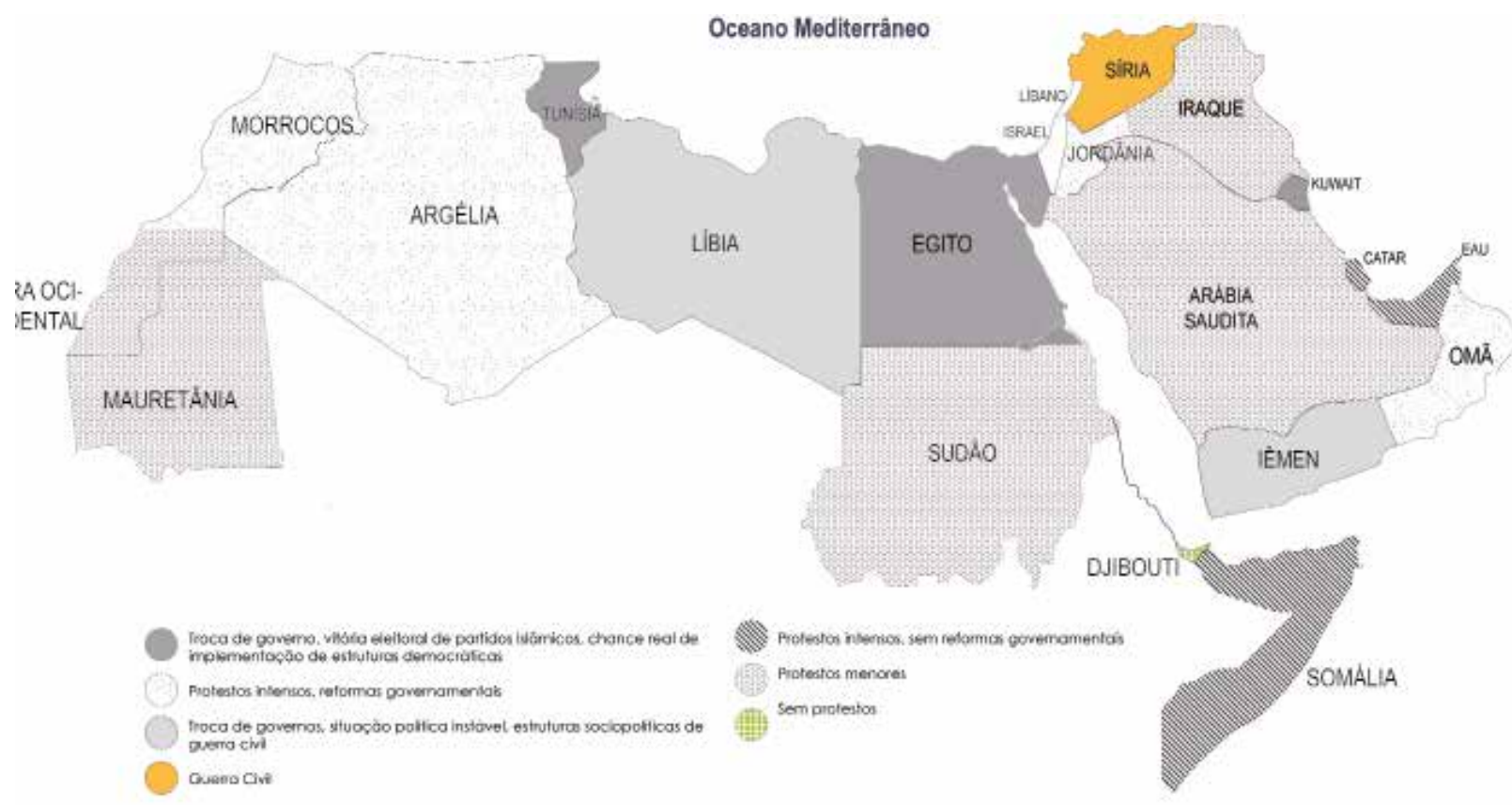


se conheça a Síria em termos de ambiente da crise, considerando suas características geográficas, políticas, econômicas, religiosas e relações com outros países, aspectos e mecanismos que constituem uma nação, uma sociedade. A partir desse mecanismo, é possível não somente que causas da crise apareçam, mas também, o modo como ocorrem dentro de uma rede de causas e efeitos.

\section{3}

\section{SOBRE O}

\section{AMBIENTE DE ORIGEM}

Com mais de 12 mil anos de existência, um dos pontos a se destacar da Síria é que faz parte de um complexo espaço geopolítico e sua localização tem importância estratégica. Seu território se articula com três continentes: Ásia, África e Europa, uma característica que desperta interesses desde as antigas civilizações egípcias, que a tinham como porta de acesso a outros países e oportunidades. Ainda geograficamente, a região era vista também pelo Império Iraniano (persas) como uma possibilidade de expansão. Esta interconexão de territórios contribuiu para que na Síria tenha surgido a primeira civilização mercantil .

O país faz fronteira com a Jordânia, Israel, Líbano, Turquia, Iraque pelo leste e com o Mar Mediterrâneo a oeste. Assim, se configura como um dos acessos marítimos entre países da Europa, da Ásia e da África. Por essa configuração, tem sido uma região de passagem e de encon- 
25 https://www.acn.org.br/ p-co ntent/ uploads/ attachments/RLRM-2016-Siria.pdf Acesso em 13 de janeiro de 2018

26 Tradução: "Ajuda à Igreja que Sofre" https://pt.wikipedia.org/wiki/Bashar_alAssad Acesso em 13 de janeiro de 2018

${ }^{27}$ Árabe: aquele que nasceu em país árabe, fala a língua árabe e segue a cultura árabe

28 Danny Zahreddine Diretor do Instituto de Ciências Sociais da PUC Minas e líder do Grupo de Pesquisa Oriente Médio e Magreb (GEOMM) e membro do Grupo de Pesquisa Potências Médias (GPPM)

Em: A Crise na Síria (2011-2013): uma análise multifatorial tro de diferentes comércios, povos e culturas, o que fez emergir uma cultura de diversidade étnica e religiosamente, sendo o país uma das exceções no mundo árabe, por ser um estado laico.

Segundo dados disponibilizados pela Fundação Pontifícia da Igreja Católica, a $\mathrm{ACN}^{25}$ - acrônimo do nome em inglês "Aid to the Church in Need" ${ }^{26}$, o mosaico religioso na Síria é formado por $92 \%$ de mulçumanos sunitas; cristãos um pouco mais de $5 \%$; os quais se dividem em católicos $2 \%$, protestantes $0,3 \%$ e ortodoxos $2,9 \%$; xiitas $0,8 \%$ e $2 \%$ por outros grupos de menor representatividade.

A República Árabe Síria, nome oficial do país, tem como capital a cidade de Damasco, reconhecida como uma das mais antigas do mundo. De etnia predominantemente árabe $^{27}$ - 90,3\% de sua população -, tem o seu restante, 9,7\% distribuídos entre curdos, arménios, aramaicos, circassianos e turcomanos, uma diversidade de etnia e de religião que, segundo Danny Zahreddine ${ }^{28}$ (2013), deixa "claro a complexidade da sociedade Síria" que se torna ainda mais multiforme e heterogênea com a entrada, desde 1948, de refugiados palestinos oriundos do conflito com Israel. Zahreddine conclui dizendo que a tentativa de "adequar as aspirações de todas estas comunidades é algo difícil, em função de características próprias da sociedade árabe, muito ligada aos laços familiares e clânicos" (2013, p. 13). O resultado dessa diversidade de comunidades, que possuem como característica comum o respeito aos seus princípios religiosos e familiares, fez com que emergisse entre elas uma relação de poder cuja ordem se dá pela obediência de cada grupo a esses princípios, dispensando assim, a necessidade de um poder centralizador.

A Síria é governada desde 2000 por Bashar al-Assad, herdeiro de Hafez al-Assad que governou o país durante trinta anos. Bashar al-Assad se elegeu por votação popular nos anos de 2003, 2007 e 2014. A última, tendo ocorrido ape- 


\section{thet}

arrogd
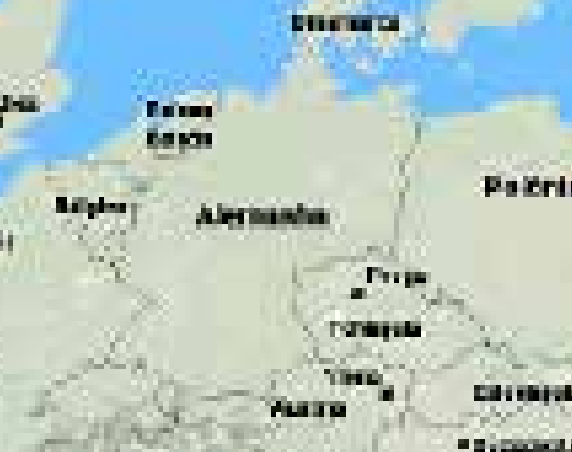

Fans

ants inimb

เพk:.

How
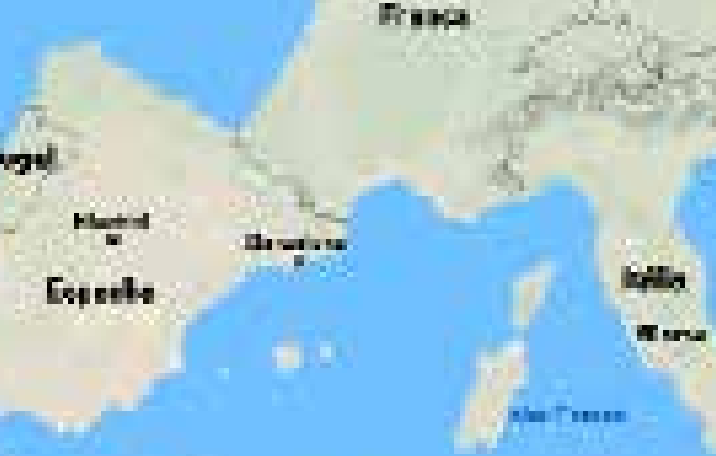

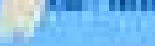

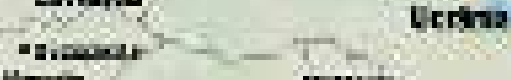

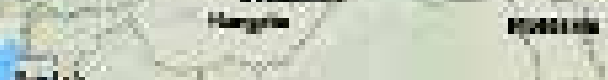

osseras

Funtis

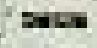
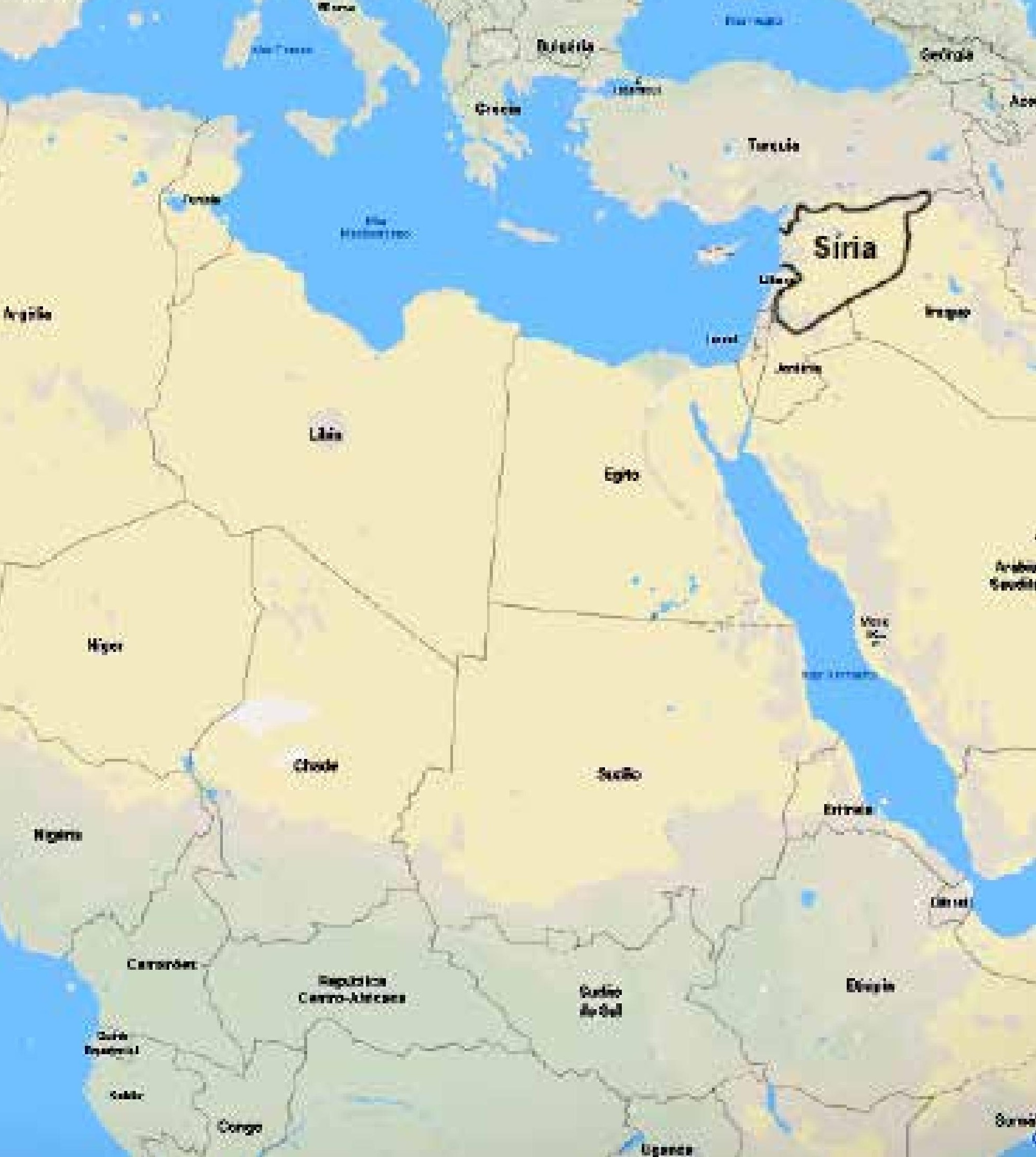
29 Organização compostas por estados árabes, com sede no Cairo que tem por objetivo manter as relações sociais, políticas, econômicas e culturais entre os participantes. http://www.itamaraty.gov.br/pt-BR/politica-externa/mecanismos-inter-regionais/3682-liga-dos-estados-arabes-lea Acesso em 15 de janeiro de 2018 nas nas regiões sob domínio do regime de al-Assad, fato que colocou em dúvida a legitimidade de sua vitória. No início de sua gestão era visto, tanto pela nação Síria quanto pela comunidade internacional, como aquele que implementaria um governo de reformas, principalmente no campo da política, dos direitos humanos e da economia, mas foi desacreditado após sua postura contundente diante das manifestações populares da Primavera Árabe (2011), ordenando que os atos populares fossem reprimidos de forma atroz por militares, o que ampliou ainda mais a indignação dos manifestantes e gerou posicionamentos de repúdio por parte de líderes mundiais, entre eles o do Canadá, dos Estados Unidos da América, da União Europeia e dos Estados membros da Liga Árabe ${ }^{29}$, da qual a Síria está suspensa desde novembro de 2011.

Em termos econômicos, a produção nacional pouco se desenvolveu na esfera industrial, tendo como fonte principal de exploração o gás e o petróleo, mantendo também a agricultura. Este é o ambiente onde se manifestou um dos principais fenômenos da contemporaneidade: a Guerra Civil da Síria, um evento que, por processos e desvios improváveis, ganhou amplitude mundial.

\section{FRONTEIRAS}

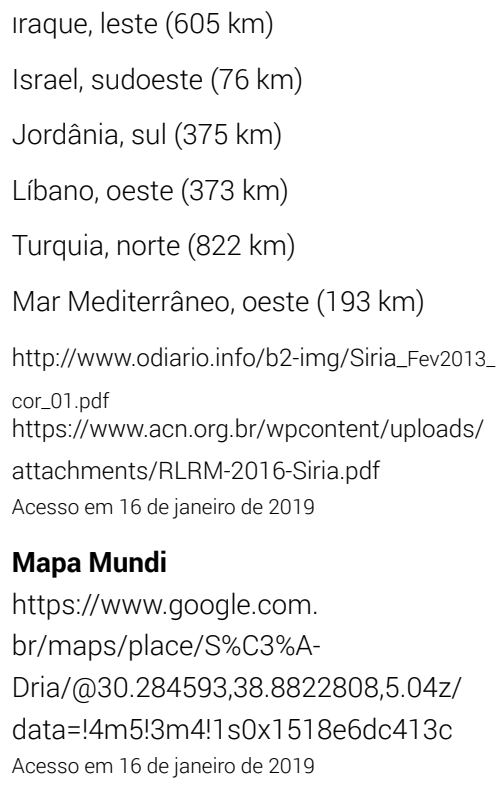




\section{4}

\section{CRISE,}

\section{ACONTECIMENTO, CAUSALIDADE E OUTROS}

Ao longo da história da humanidade, uma sucessão de transformações ocorreu para que se chegasse onde se chegou, tanto em termos de desenvolvimento, quanto de destruição. Essas transformações inevitavelmente surgiram de processos circunstanciados por acontecimentos e rupturas que mudaram o cenário vigente. Entre ordem e desordem, sistemas abertos se reorganizaram diante da informação com caráter de evento único que trouxe consigo a potência da novidade destruidora.

Slavoj Žižek, incorpora ao conceito de acontecimento o de causalidade e diz que "um acontecimento é assim, o efeito que parece exceder suas causas - e o espaço de um acontecimento é aberto pela brecha que separa o efeito das causas" (2017, p. 9). Para ele, acontecimento e suas causas são indissociáveis, e assim toma emprestado da teoria de sistemas um dos principais conceitos que envolvem a concepção de sistemas complexos: a causalidade. O filósofo sloveno explica que um acontecimento parece exceder suas causas, talvez porque estas residam no espaço do ordinário, do cotidiano, mas que ao se relacionarem causalmente, influenciando umas as outras, sejam potencializadas a romper com a brecha para o surgimento de um evento único e desestabilizador. 


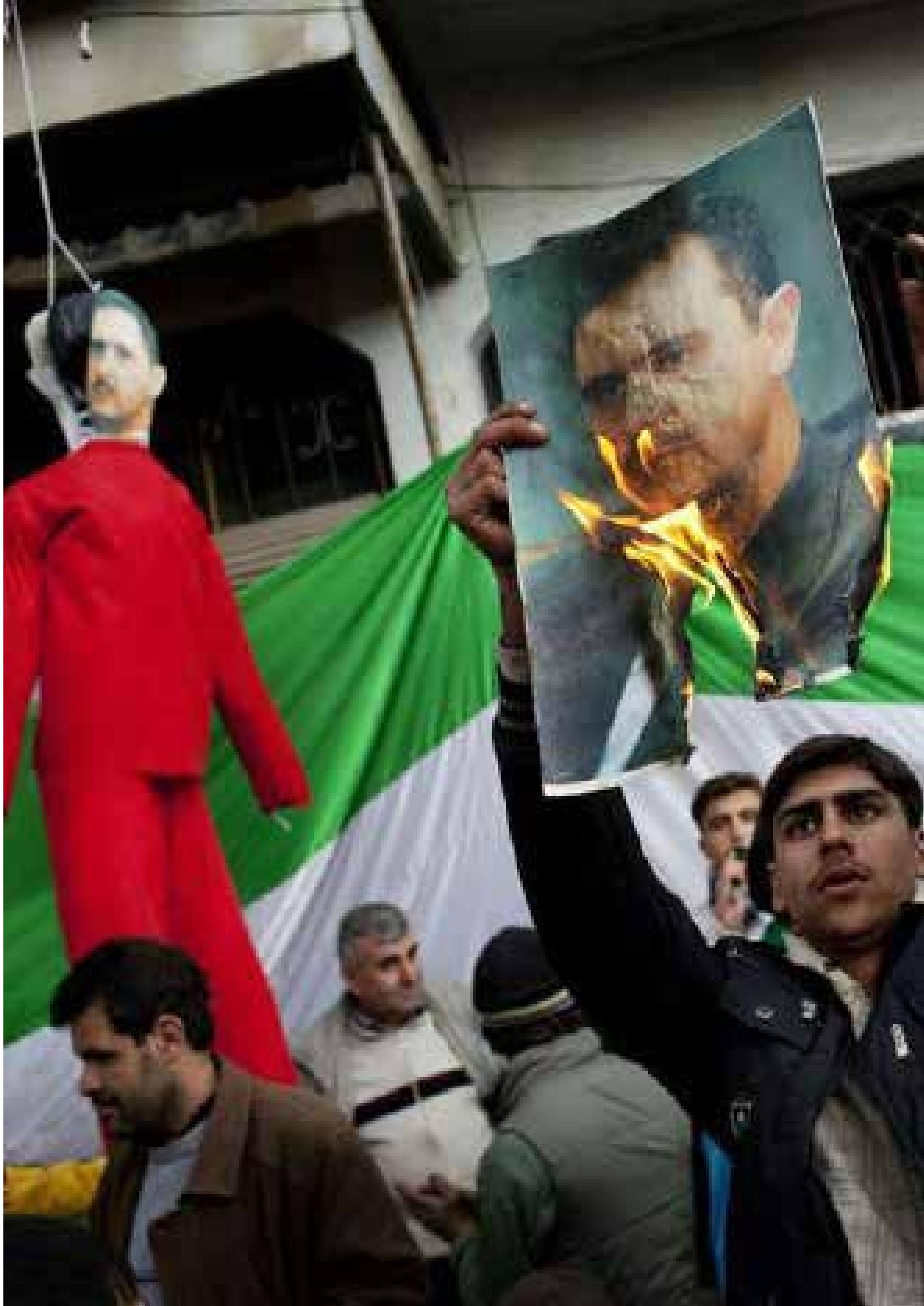




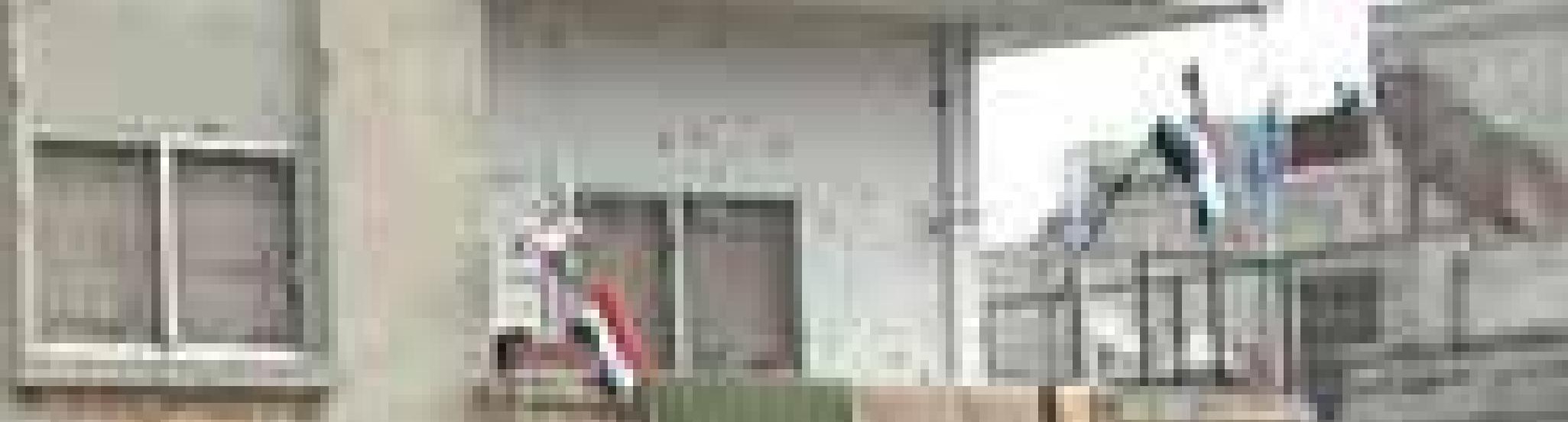

Tit

wast

s

n

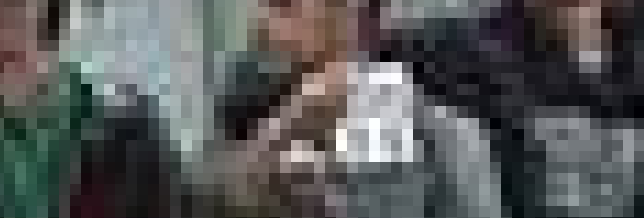

1

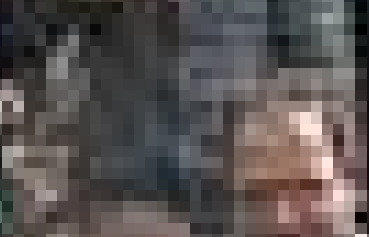

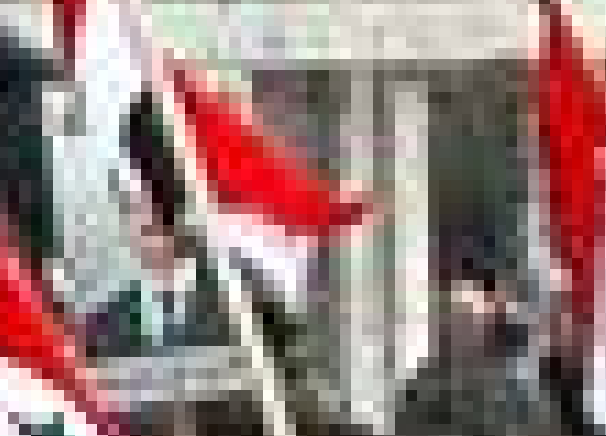

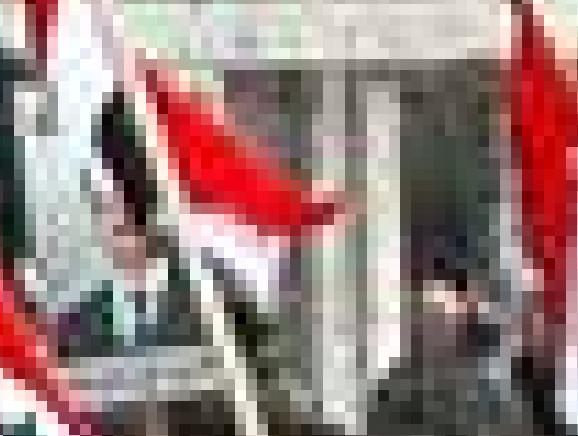

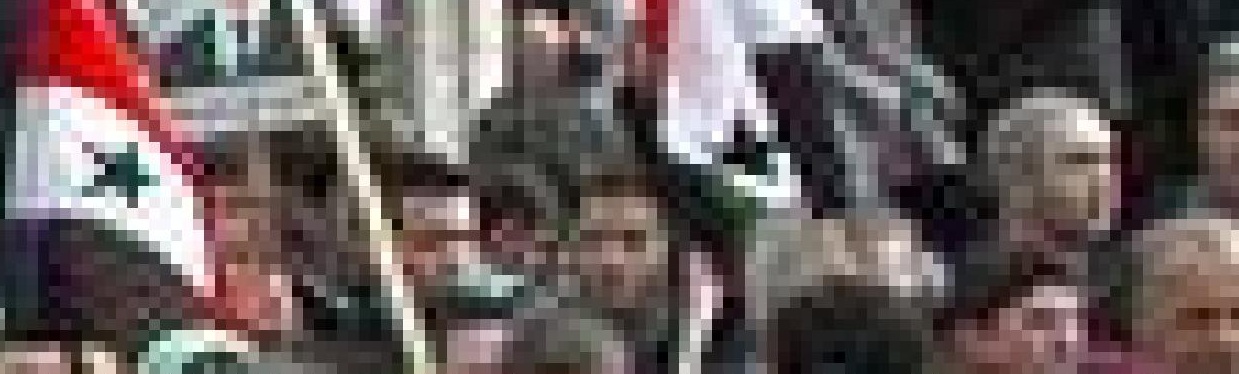

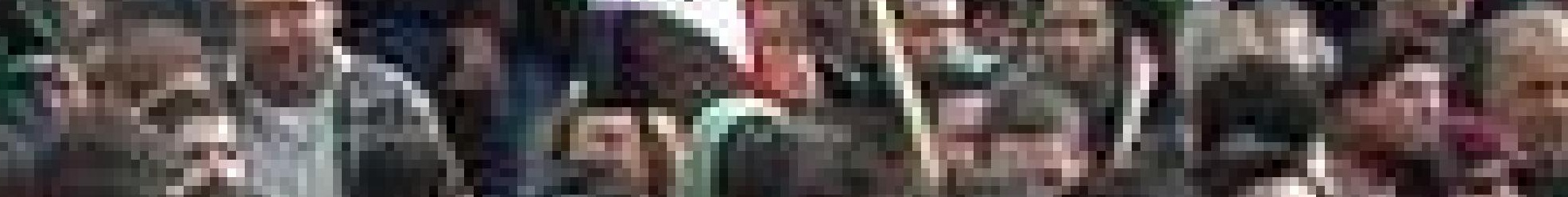
1

$x^{2}+x^{2}$

$+1$

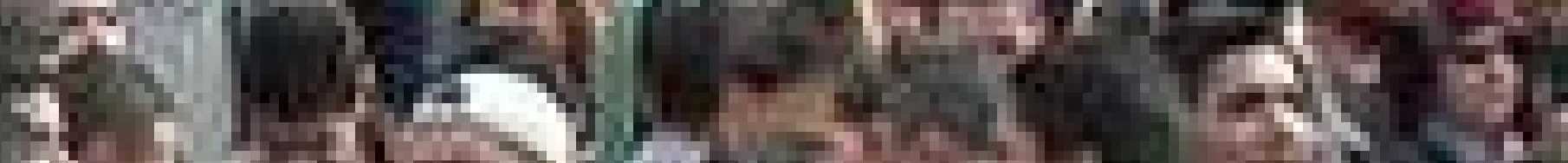

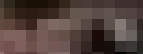

$+1$

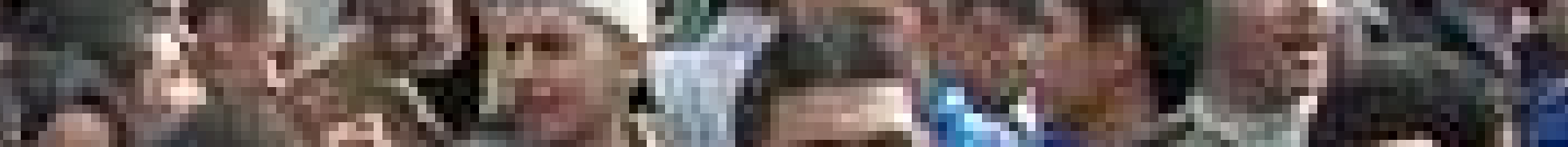
(19+1

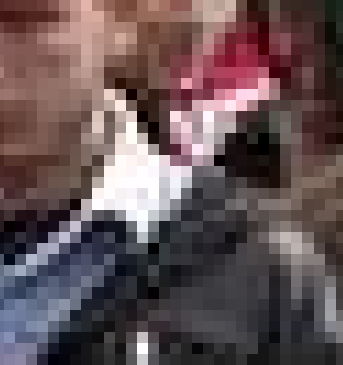

ats 1

17 mat

B
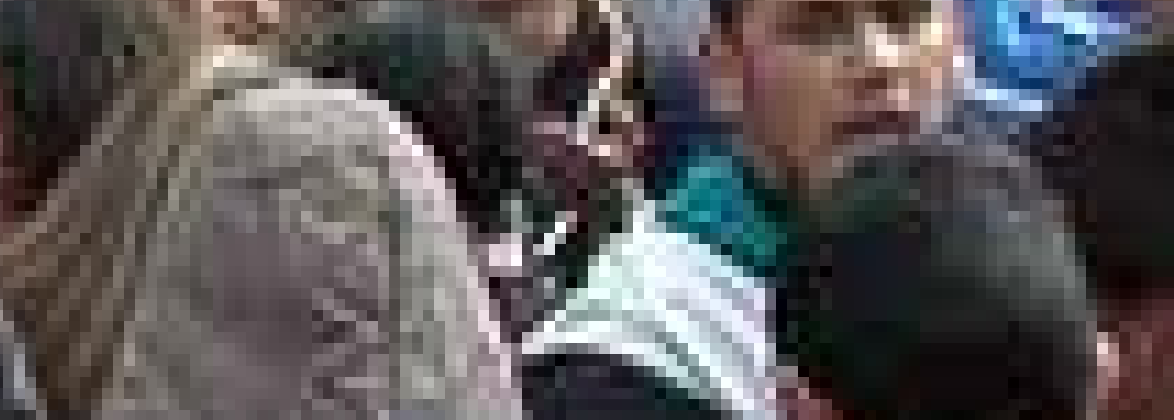



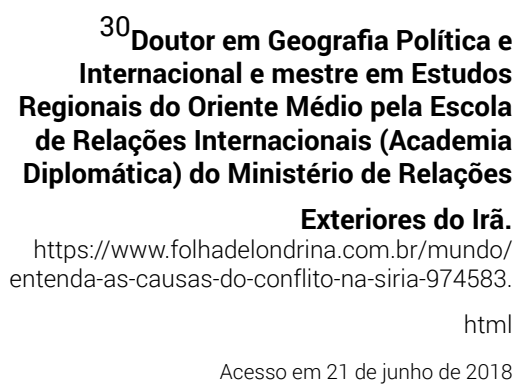

Acesso em 21 de junho de 2018

${ }^{31}$ Sobre os eventos de confrontro e

disputa da Síria https://escola.britannica.com.br/artigo/S\%C3\%ADria/482622 Acesso em 21 de março de 2018
Ao olhar para a Síria as evidências apontam para o fato de que a guerra não surgiu de uma única causa. O ponto de partida não foi somente a insatisfação do povo. Uma nação que, de acordo com Jorge Mortean (2017) ${ }^{30}$, “nunca colocou um papelzinho numa urna, assim como um saudita e um iraquiano (antes da invasão norte-americana, em 2003)" necessita de um processo de adaptação para lidar com os complexos instrumentos que ela disponibiliza e, segundo ele, "a democracia é uma construção social prática, (que) vai se dando aos poucos". Mortean acredita que "o desenrolar da guerra civil foi totalmente diferente do que aconteceu na Primavera Árabe". Ela foi um dos eventos críticos que, dentro de uma cadeia de causas, fez emergir os efeitos que evidenciam a complexidade do fenômeno. Resultado de uma sucessão de acontecimentos, precedidos pela causalidade de uma estrutura de retroalimentação de causas vindas de um passado distante ao encontro de um presente totalmente novo, como a possibilidade de votar.

Uma entre as diversas causas da crise da Síria está em seu longínquo passado, não em um ponto específico, mas em vários que, por padrão, representam a tentativa e efetivação do domínio de seu território, desde os Impérios mulçumanos, como o Otomano até o domínio da França, que durou entre 1920 e 1946, para então ser governado por militares que lideraram outros conflitos contra países vizinhos, como as disputas com Israel e Iraque e em colaboração com o Líbano ${ }^{31}$. A Síria tem em sua história e em sua memória, eventos de guerra e de conflitos que inevitavelmente deixaram marcas e fazem parte do que tem sido o país. Lutar, proteger, defender, conquistar são ações vividas por seus antepassados que, de um modo ou de outro, fazem parte do que são como sujeitos e como nação.

Um aspecto a se considerar se coloca como pergunta: a quem este conflito interessa? Em termos sistêmicos, é possível observar a crise pela perspectiva da sinergia de elementos que fazem uso do movimento de outros 
para empreender conjuntamente esforços, criando assim um movimento maior. Como observa Mortean, (2017) "o desenrolar da guerra civil foi totalmente diferente do que aconteceu na Primavera Árabe”. Há uma sucessão de desdobramentos da crise que atendem a outros interesses, assim, seus efeitos, embora aparentemente comuns, possuem causas distintas. Segundo artigo publicado pelo CPPC - Conselho Português para a Paz e Cooperação ${ }^{32}$, o conflito na Síria é militar, "instigado, financiado e mantido a partir do exterior por aqueles para quem os justos anseios do povo sírio de mais justiça e democracia servem apenas para justificar mais uma guerra de agressão já em curso" e como estratégia, usam recursos de desestabilização interna, treinamento e financiamento de armamento para grupos mercenários que sabotam estruturas essenciais como estradas, gasodutos, oleodutos etc.

A visão sobre o conflito sírio como uma relação sinérgica decorre do estado de interação de causas e desdobramentos apresentados pelo evento, o que atribui a cada um desses maior valor em função de seu papel na dinâmica do todo. A sinergia é uma manifestação de esforços para uma finalidade comum, que se dá no momento de interações coordenadas das partes. Neste sentido, as distintas causas da crise convergem para efeitos comuns, característica que potencializa eventos futuros.

Por diversos motivos, a guerra da Síria tem despertado a atenção do mundo, seja por questões relacionadas à solidariedade e compaixão de outros povos, seja por questões de ordem política e econômica. Como toda crise, há o rompido com o status quo de diversos contextos, desde os de ordem pessoal aos de maior amplitude, entendidos como fenômenos globais.

\section{CPPC}

http://www.odiario.info/b2-img/Siria Fev2013_cor_01.pdf

Acesso em 16 de dezembro de 2018 


\section{O conflito em números}

${ }^{33}$ http://www.portalbrasil.net/asia_siria. htm Acesso em 22 de março de 2019

34 Grupo de monitoramento do Reino Unido com uma rede de fontes no território Sírio. https://www.bbc.com/news/world-middle-east-35806229 Acesso em 22 de março de 2019

Após quase oitos anos de conflito, os números não param de crescer. Segundo dados do Observatório Sírio para os Direitos Humanos ${ }^{33}$, até dezembro de 2018 há o registro de 367.965 mortes, excluindo desse saldo os desaparecidos, que somam 192.035. Ou seja, mais de meio milhão de pessoas morreram ou desapareceram, um número que diante da população total do país, 16,1 milhões $(2000)^{34}$, demonstra o quão devastadora tem sido essa guerra.

Síria - áreas de disputa entre governo e oposição. Zonas ocupadas pelo exército, oposição ou zonas disputadas

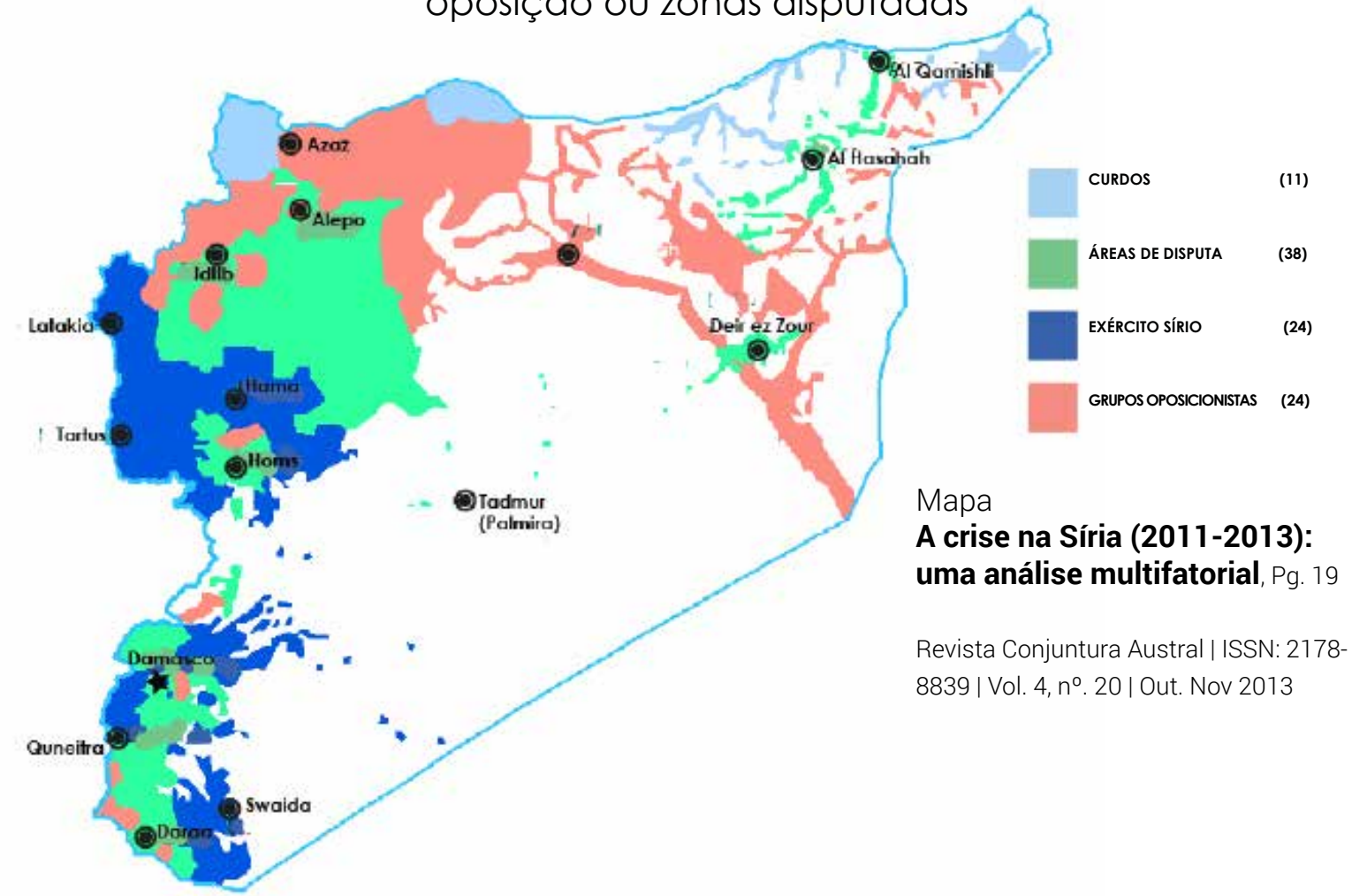

${ }^{35}$ ACNUR - Alto Comissariado das Nações Unidas para os Refugiados

${ }^{36}$ https://data2.unhcr.org/en/situations/ syria\# ia\#_4661.1834704751.1550709536993155851.1545426205 Última atualização em 07 Feb 2019

37 https://www.acnur.org/port gues/2018/09/12/sete-fatos-sobre-a-crise-na-siria/Fonte: http://vdc-sy.net/en/\# Acesso em 22 de março de 2019
Sobre os sobreviventes, a ACNUR ${ }^{35}$, apresentou relatório em fevereiro de 2019 onde estão registrados mais de 5,6 milhões de refugiados sírios, que se somam aos mais de 6 milhões de deslocados internos ${ }^{36}$, pessoas que foram obrigadas a mudar de moradia dentro do próprio país. Segundo a ACNUR, a Síria "é o país que gera o maior número de pessoas deslocadas à força no mundo e mais da metade de sua população foi forçada a fugir." 37 
Após uma série de acontecimentos, a guerra civil na Síria se converteu em uma crise que abrange não somente o seu povo e seu território, mas a comunidade internacional. Há tempos passou de uma crise local para uma crise em escala global, que impacta também outros países, cada um de maneira distinta, uma vez que um acontecimento nunca afeta do mesmo modo ambientes diferentes e seus elementos.

\section{5}

\section{UM PAÍS, UMA CRISE, UM MUNDO AO REDOR}

Atualmente um dos problemas mais complexos da humanidade se refere ao do deslocamento forçado de pessoas, que encontram na fuga para outros lugares a única alternativa de manutenção da vida. São vítimas de situações de guerras civis, de perseguições ideológicas, políticas e religiosas, da escassez de alimentos e de outras situações que tornam insustentável a permanência em seu país de origem.

Em sucessivos relatórios que abordam o tema, números expressam um aumento considerável do fluxo migratório, que ocorre muitas vezes no limiar do sucesso ou do fracasso das tentativas de fuga. Ainda de acordo com a ACNUR $^{38}$, nos primeiros cinco meses de 2016 morreram 2.510 migrantes, entre eles, muitos que fugiam da crise na Síria. Um dado que traz consigo, além da falta de precedentes, o quanto os que necessitam fugir se noticias/noticia/acnur-se-mostra-preocupado-pela-alta-taxa-de-mortos-no-mediterraneo/

Acessado em 28 de março de 2019 
$39_{\text {http://www.internal-displacement.org/ }}$ about-us Acesso em 20 de fevereiro de 2019

40 Professora em Direitos Humanos do Refugiado e Direito da Criança e do Adolescente na PUC/SP, em palestra proferida no Centro de Pesquisa e Formação Sesc - SP em maio de 2017

Gráficos

https://www.bbc.com/news/world-middle-east-35806229 http://vdc-sy.net/en/\# Acesso em 22 de março de 2019 expõem, se submetendo a condições de exploração e risco de perder suas vidas.

A Guerra Civil da Síria já representa um dos maiores índices de pessoas deslocadas internamente (IDPs - Internally displaced persons); pessoas que foram forçadas a deixar suas casas em busca de proteção em outro lugar, mas se mantendo dentro do país. Segundo relatório de dezembro de 2017, do Centro de Monitoramento de Deslocamento Interno (IDMC) ${ }^{39}$, o conflito já havia provocado o deslocamento de 6.784 .000 pessoas. O mesmo relatório afirma que a continuidade dos ataques levou, no primeiro semestre de 2018, a migrações internas de mais $1.216,000$, o que chega a quase a metade da população síria. Números que se tornam mais críticos quando somados aos que estão fora do território nacional, totalizando mais de 12 milhões, o que torna a Síria o único país no mundo a ter mais de dois terços de sua população forçadamente fora de seus lares.

Segundo a pesquisadora Lucinéia Rosa dos Santos ${ }^{40}$, "hoje vivemos uma crise mundial intensa, uma $3^{a}$ guerra mundial, num outro tipo de contexto, que não é territorial". A guerra da Síria se expande como crise em vários aspectos distintos, criando novos arranjos por onde se espalha. Tanto questões internas quanto externas compõem a multidimensionalidade da crise e sustentam o impasse de sua resolução. Para Zahreddine, "a retroalimentação das forças governamentais e oposicionistas por
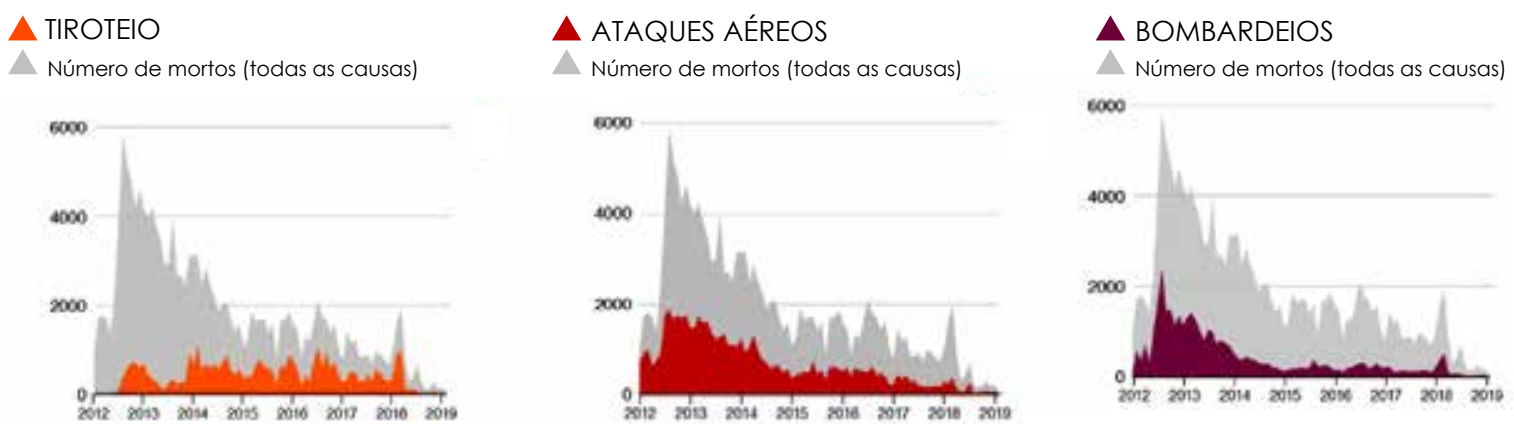
seus respectivos aliados sejam eles domésticos, regionais ou potências mundiais, não permite o fim das hostilidades" (2013, p. 20). O modo como o evento se distribuiu torna a possibilidade de tomada de poder pelas partes envolvidas cada vez mais difícil e aparentemente cada vez mais distante que se chegue ao fim do conflito.

Os cinco destinos mais escolhidos por refugiados sírios
Gráfico baseado em dados provenientes de:

https://data2.unhcr.org/en/situations/syria\#_ ga $=2.240025859 .1066734115 .1552758689-$ $993155851.1545426205 \&$ gac $=1.217394722 .1552508048$. EAlalQobChMI5YnyjPf_4AIVloKRCh1wCwlbEAAYASAAEgLfbfD_BwE

Acesso em 16 de dezembro de 2018

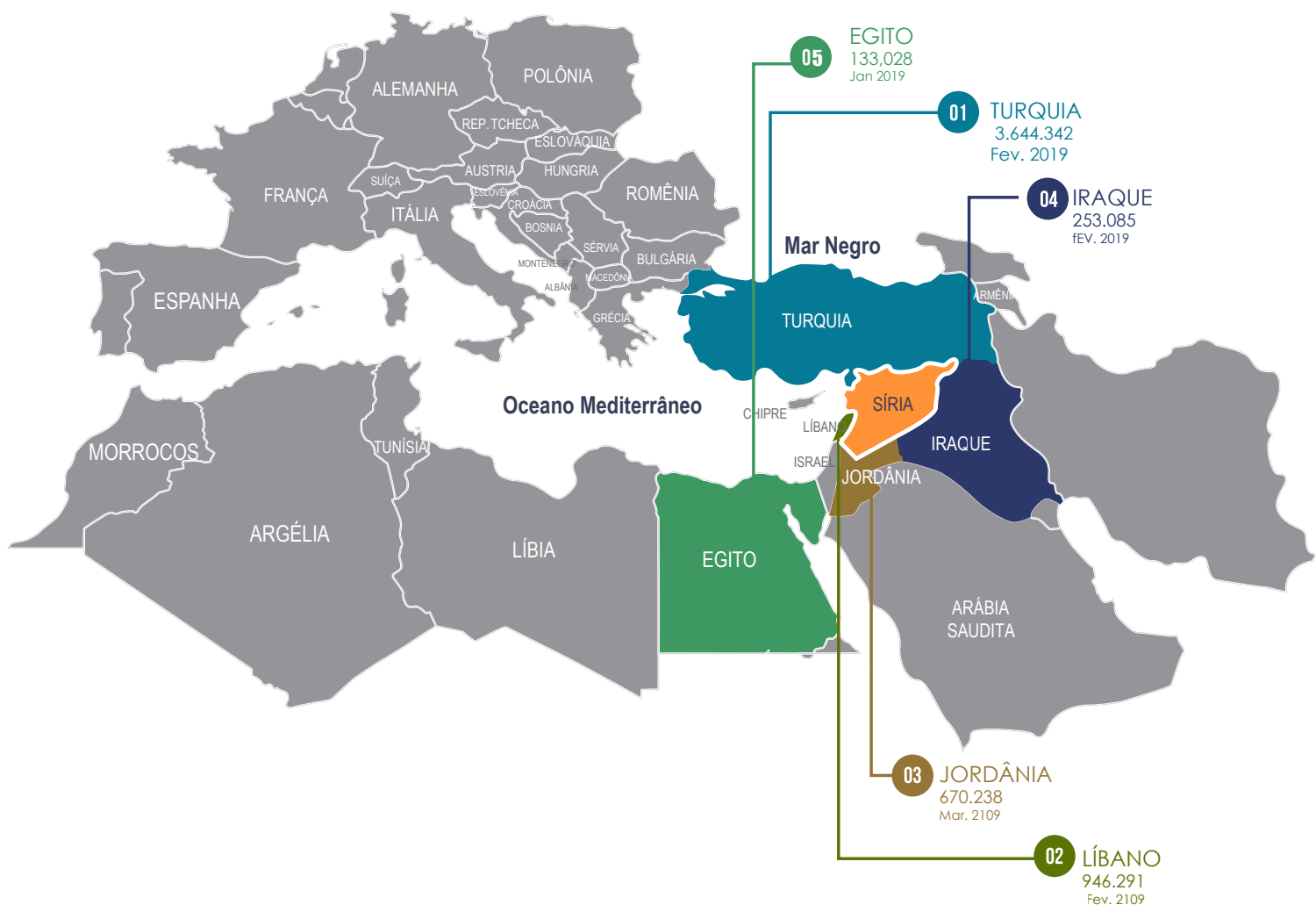

\section{6}

\section{A DIÁSPORA}

Entre os países que mais têm refugiados distribuídos pelo mundo, principalmente pelo continente Europeu, a Síria ocupa o primeiro lugar. Segundo relatório ${ }^{41}$ da ACNUR, no Líbano uma entre quatro pessoas é um refugiados sírio, ou seja, um quarto da população do país.

O êxodo de sírios para outros países contribui significativamente para que a segunda década dos anos 2000 tenha tido

\section{Diáspora}

Termo usado primeiramente para se referir ao povo judaico, diáspora define o deslocamento, normalmente forçado ou incentivado, de grandes massas populacionais originárias de uma zona determinada para várias áreas de acolhimento distintas.

${ }^{41}$ Global Trends FORCED DISPLACEMENT IN 2017 Em

https://www.unhcr.org/5b27be547.pdf

Acesso em 16 de dezembro de 2018 
um aumento de mais de 50\% no número de migrações no mundo, passando dos 42,7 milhões em 2007 para 68,5 em 2017. Em relatório anual realizado pela ACNUR sobre deslocamento forçado, se evidencia que "1 em cada 110 pessoas no mundo está deslocada, em comparação com 1 em 157 há uma década, "42 Esse aumento ocorreu com maior ênfase entre 2012 e 2017, período de maior migração de sírios.

O fenômeno da migração, segundo Agier (2015), pela perspectiva do indivíduo, não se estabelece como crise somente no momento em que o refugiado entra no país de refúgio. Ela é anterior, é múltipla e evolui por processos diversos. Desde as causas da partida, que envolve se desligar de uma vida em um lugar, se separar de pessoas, identificar os meios necessários e possíveis para sair, mesmo que sob risco de morte e, por fim, para onde ir.

Entre as rotas de fuga mais utilizadas pelos sírios estão aquelas que levam a Jordânia, ao Líbano, Iraque e Turquia. Países que criaram campos de refugiados, como espaços reservados especialmente para recebê-los, estruturas localizadas próximas às fronteiras. Esses espaços são uma espécie de fronteira social, onde se vive à margem de uma outra sociedade, em uma situação transitória que a qualquer momento pode ter fim.

Outro bloco de países afetado pela crise da Síria é o da União Européia, que mesmo com uma única fronteira terrestre com o país, a da Turquia, desperta o interesse dos migrantes como sendo mais uma das alternativas de fuga. Entre as rotas, uma das opções é a do oceano Mediterrâneo, o que torna muitas vezes a jornada um risco eminente de morte, dadas as condições das embarcações que, em geral, são frágeis e costumam embarcar uma quantidade de pessoas que vai além de suas capacidades.
42 gues/2018/09/12/sete-fatos-sobre-a-crise-na-siria/

Acesso em 16 de dezembro de 2018 
$55 \%$ dos refugiados no mundo vieram de três países

Ago | 2017

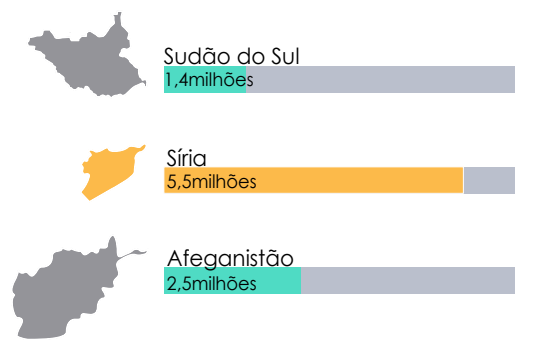

43

https://nacoesunidas.org/travessia-migrantes-diz-relatorio-da-onu/

Acesso em 23 de dezembro de 2018
Em relatório divulgado em janeiro de 2018 pela Organização Internacional para as Migrações (OIM) ${ }^{43}$ se evidenciou que a travessia do mediterrâneo é uma das rotas mais mortais para migrantes, e segundo dados desse mesmo documento, cerca de 33.761 pessoas morreram entre os anos 2000 e 2017 ao tentar chegar em países da Europa, como Turquia e Itália. Há indicação no relatório também, que somente no ano de 2016 foram registradas 5.096 mortes.

A busca pela sobrevivência vai além das fronteiras com países vizinhos e muitos colocam suas esperanças em países mais distantes. Da União Europeia, os que mais atraem os migrantes são Turquia, Itália, Grécia, Alemanha e Suécia e outros de menor expressividade em termos que número de imigrantes. Os três primeiros se destacam em decorrência de sua posição em relação ao mediterrâneo, o que os tornou uma das principais rotas de entrada na Europa.

Com o excesso de migrantes pelas rotas marítimas, sobretudo as que permitem a entrada na Europa pela Grécia e Itália, a entrada no continente Europeu tornou-se cada vez mais difícil o que demandou por um processo de reorganização do fluxo migratório, que passou a seguir por rotas terrestres. Essa mudança de procedimento envolveu outros países da União Europeia que até então não tinham sido afetados significativamente pela guerra, como a Alemanha, por exemplo, que permitiu entrada aos refugiados. Para chegar em território alemão, além de passar pela Turquia, os migrantes cruzam também a Macedônia, Sérvia, Hungria e Áustria.

Diante dessa mudança na rota dos fluxos, novas crises emergiram, tornando insustentável que decisões tomadas pelos países envolvidos fossem realizadas de modo individual. Assim, eles também precisaram se auto-organizar como elementos e como sistema. A sucessão de chegadas de grupos de migrantes, que ultrapassavam ou estavam na 
eminência de ultrapassar as fronteiras de alguns países do continente Europeu, se conformou em um movimento não-linear que se auto reforçou, se caracterizando assim, como uma das propriedades de sistemas não lineares, ou seja, como um processo disperso com potencial para promover grandes mudanças ao longo de seus desdobramentos. A auto-organização é mais um conceito base para os estudos da complexidade, por tratar de compreender e explicar a dinâmica de construção de estruturas próprias dentro de um sistema de modo autônomo e descentralizado. Este conceito surgiu, assim como muitos dos outros vistos até este momento, de áreas diferentes como ecologia, economia, ciência da computação e outros que o estudam como um caminho para compreender o comportamento de seus objetos particulares.

Como explica Morin (1996), existem conceitos que são conceitos-mala, que possuem compartimentos onde coisas vão se encaixando e organizando, ou seja, necessitam de outros para serem compreendidos. Esse é o caso da auto-organização, cujas características precisam ser exploradas à luz de uma visão sistêmica. Outro desses é o de autonomia, fundamental para a compreensão da auto-organização, e que pode ser iluminado pelo princípio teórico do encerramento operativo do qual, segundo Luhmann, "partem todos os novos preceitos sobre sistemas, que não podem estabelecer pontos de contato com o meio" (1995, p. 111). A partir dessa premissa é possível afirmar que as operações internas de um sistema auto- organizado, como o fluxo de migração síria, podem até ser provocadas por estímulos externos, mas o seu modo de operar obedecem a regras internas.

A autonomia desses sistemas indica que realizam suas operações a partir de regras próprias, sem influência do meio. Um aspecto a se observar é que são organizações que evoluem à medida em que realizam ajustes estruturais, o que significa que conseguem se manter em decorrência do alto grau de diversidade de seus elementos

Entrada de refugiados sírios na Turquia https://nacoesunidas.org/curdos-sirios-fugindo-para-turquia-chegam-a-140-mil-aumentando-necessidades-humanitarias/ Acesso em 11 de março de 2019 


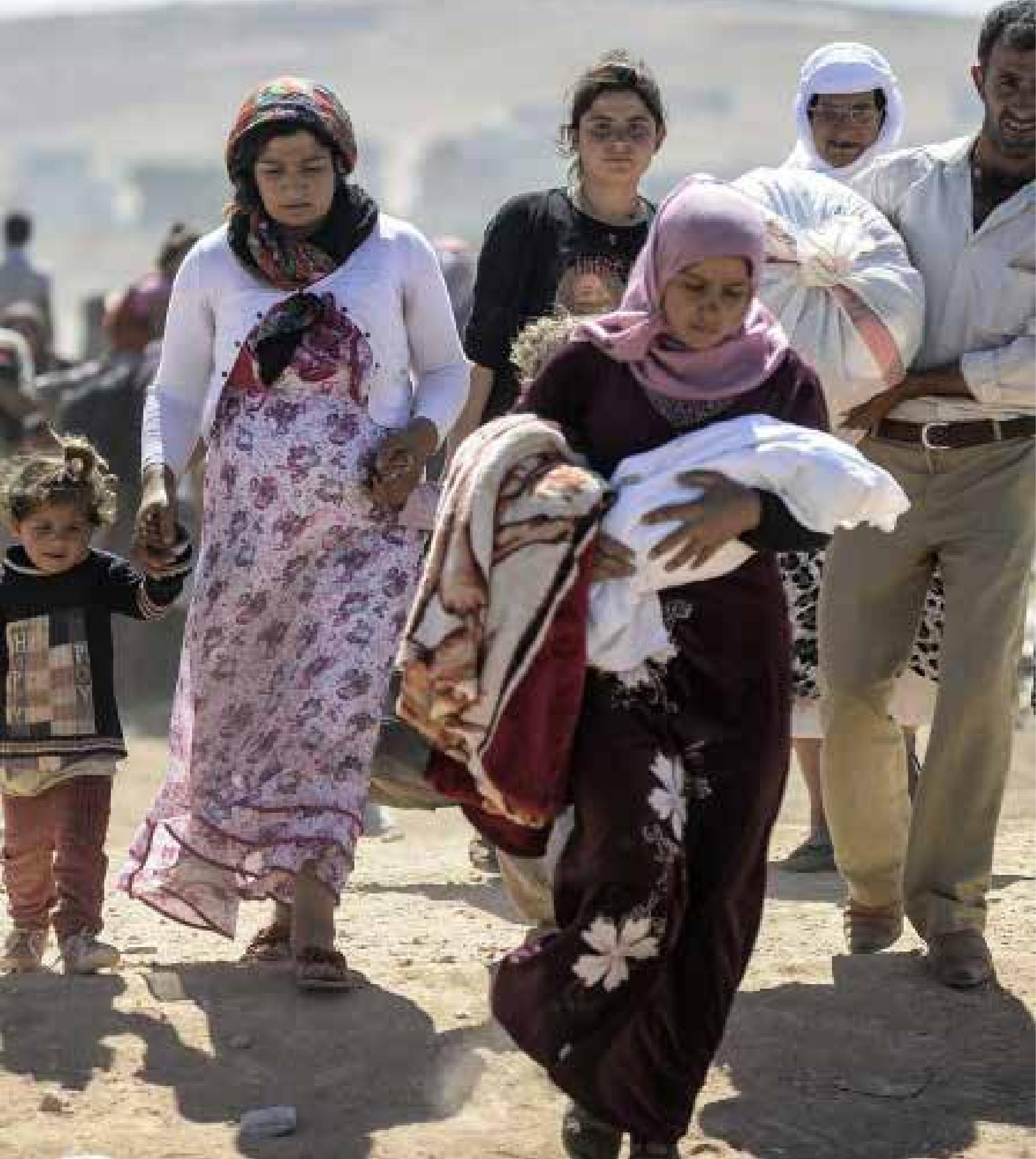



e de sua capacidade de suportar alterações em seu meio. No mundo contemporâneo, no qual cada vez mais as relações se estruturam em redes de relações descentralizadas, a teoria da auto-organização é uma das chaves para a resolução dos principais desafios postos aos diversos domínios, que tratam do seu planejamento e de sua gestão, como as redes de comunicação social, do trabalho colaborativo, da participação social e outras.

Rotas terrestres e marítimas do refúgio

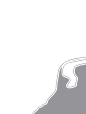

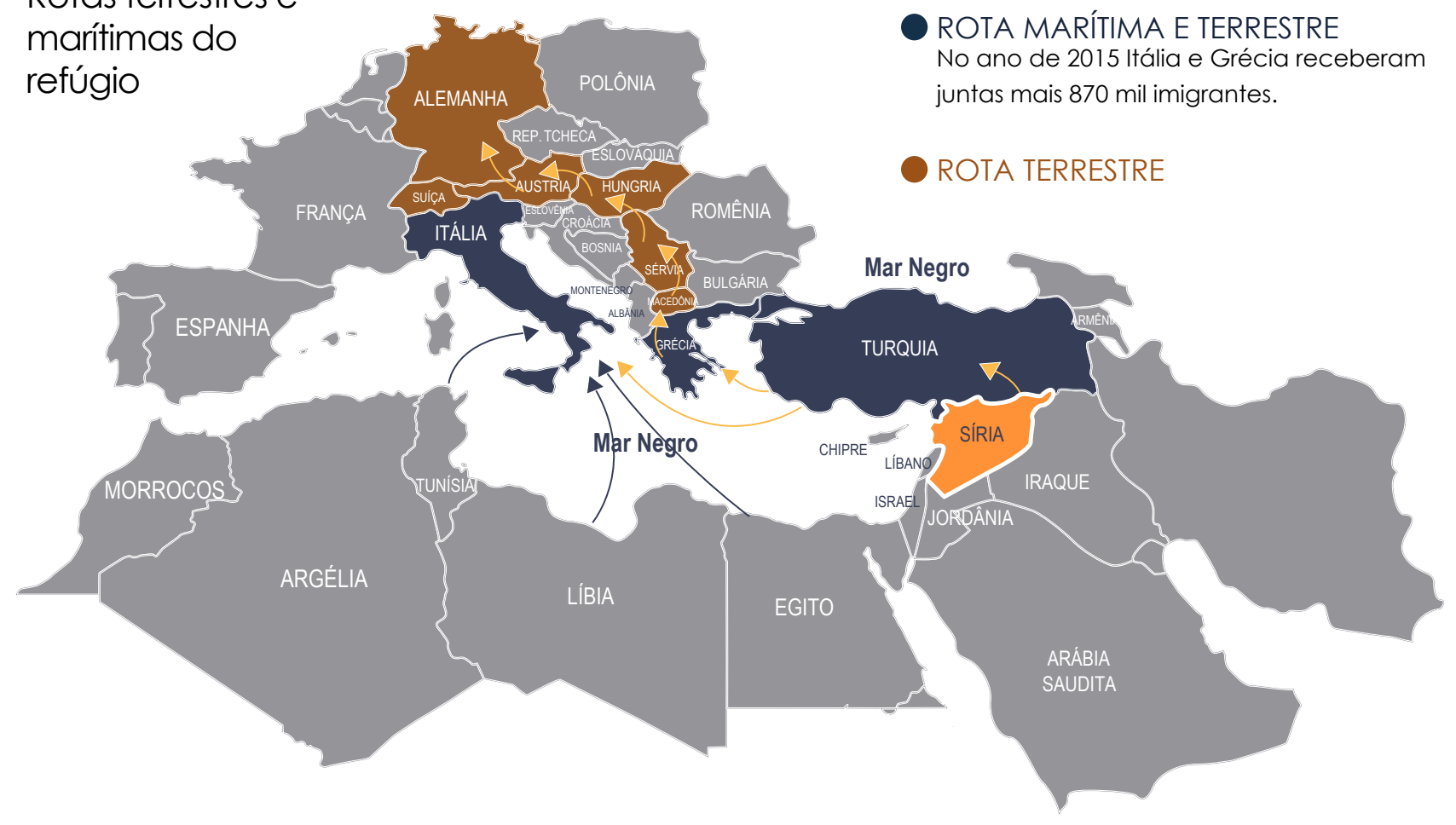

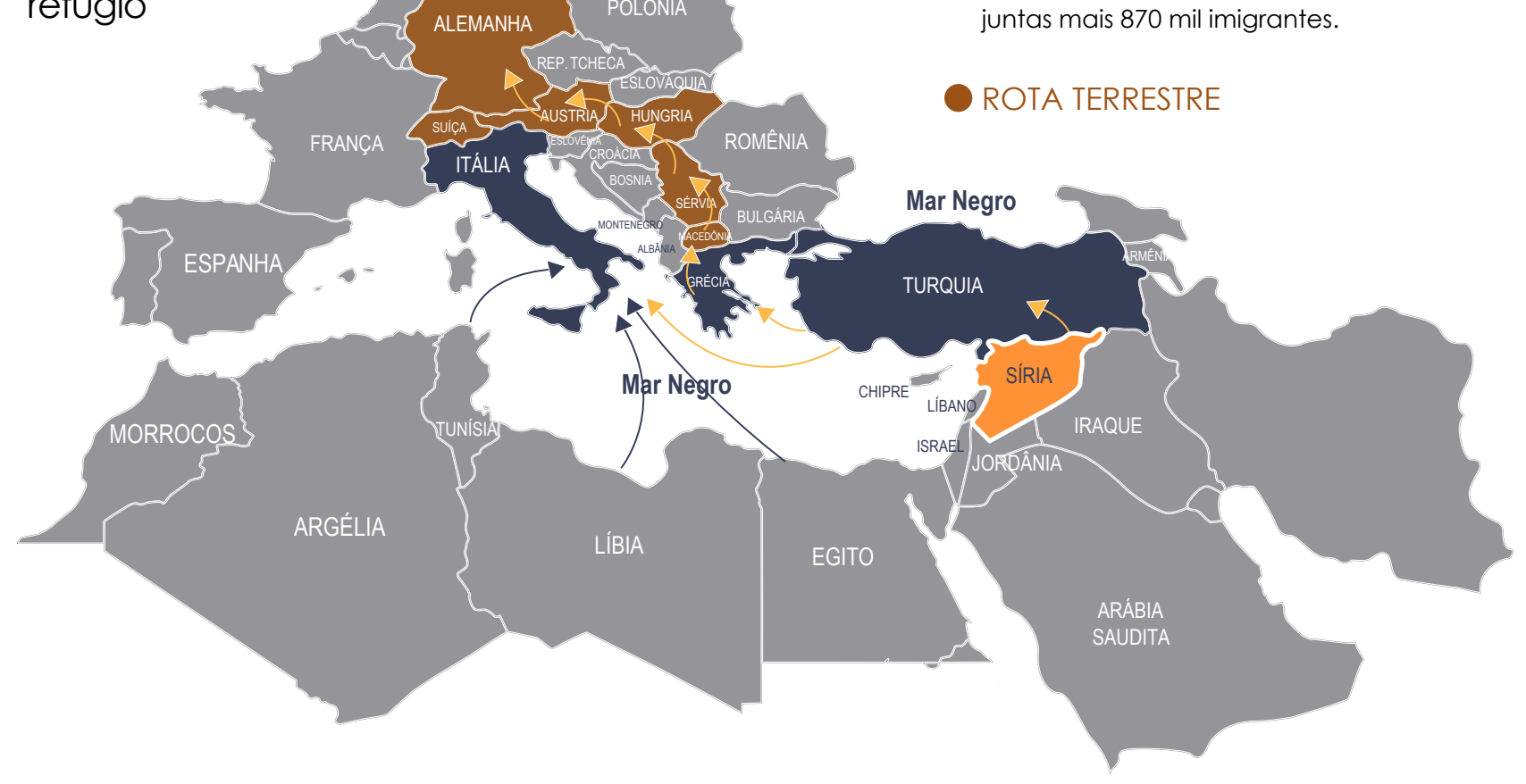

ROTA MARÍTIMA E TERRESTRE No ano de 2015 Itália e Grécia receberam juntas mais 870 mil imigrantes.

Total de chegadas mensais na Europaentre os anos de 2016 e 2018

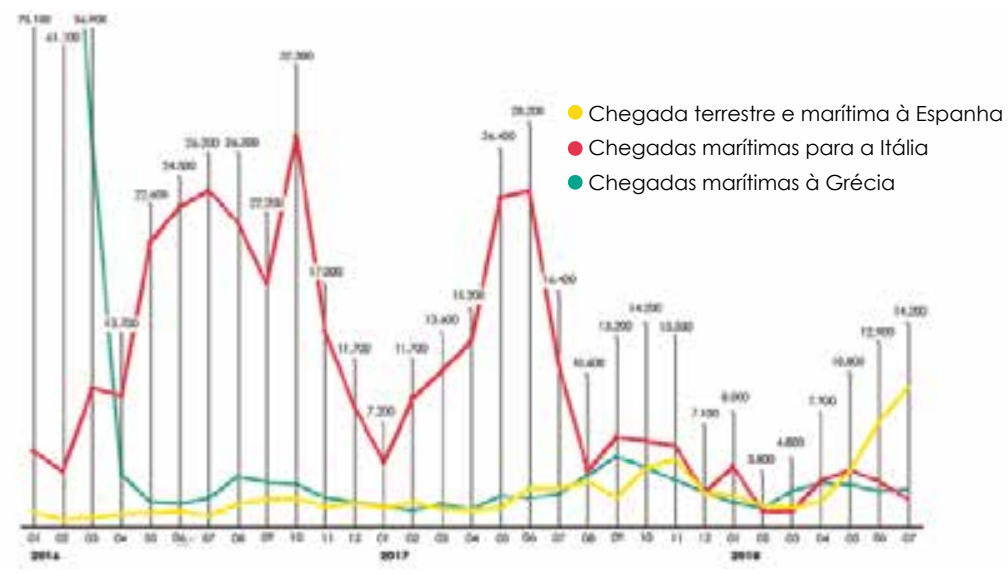

\author{
Relatório ACNUR DESPERATE \\ JOURNEYS - Refugees and \\ migrants arriving in Europe and \\ at Europe's borders \\ JANEIRO-AGOSTO 2018 \\ https://www.unhcr.org/desperatejour- \\ neys/ \\ Acesso em 13 de novembro de 2018
}


Embora seja um conceito consideravelmente abstrato, é possível equacioná-lo pela ideia de que a auto-organização diz respeito ao modo como elementos diferentes funcionam juntos a partir de regras simples e com coerência, sem que haja uma coordenação central. Padrões percebidos neste tipo de processo têm orientado para a modelagem de sistemas de diversas áreas, que visam proporcionar um ambiente para elementos se organizarem de modo distribuído, a partir de regras simples e autonomamente.

A chegada em cada país, em cada ambiente, acontece sob distintas condições. São indivíduos que chegam e que trazem consigo sua cultura, sua fé, suas esperanças, seus receios, suas forças, fraquezas e estratégias para lidar com os desafios que o novo lugar lhes colocará. Entre esses desafios um se destaca muito claramente: a fronteira ou as Imagem

Refugiados sírios e afegãos remam em direção à ilha grega de atualizar a partir da perspectiva do encontro, da linha de Lesvos. que divide, mas também une. A fronteira entendida como ACNUR / /vor Pricketthttp://tracks.unhor. um lugar simbólico, limítrofe entre o que resiste e o que org/2015/12/2015-the-year-of-europes- se transforma, um processo de transição entre o que se -refugee-crisis/ Acesso em 13 denovembrode 2018 mantém e o que se adapta.

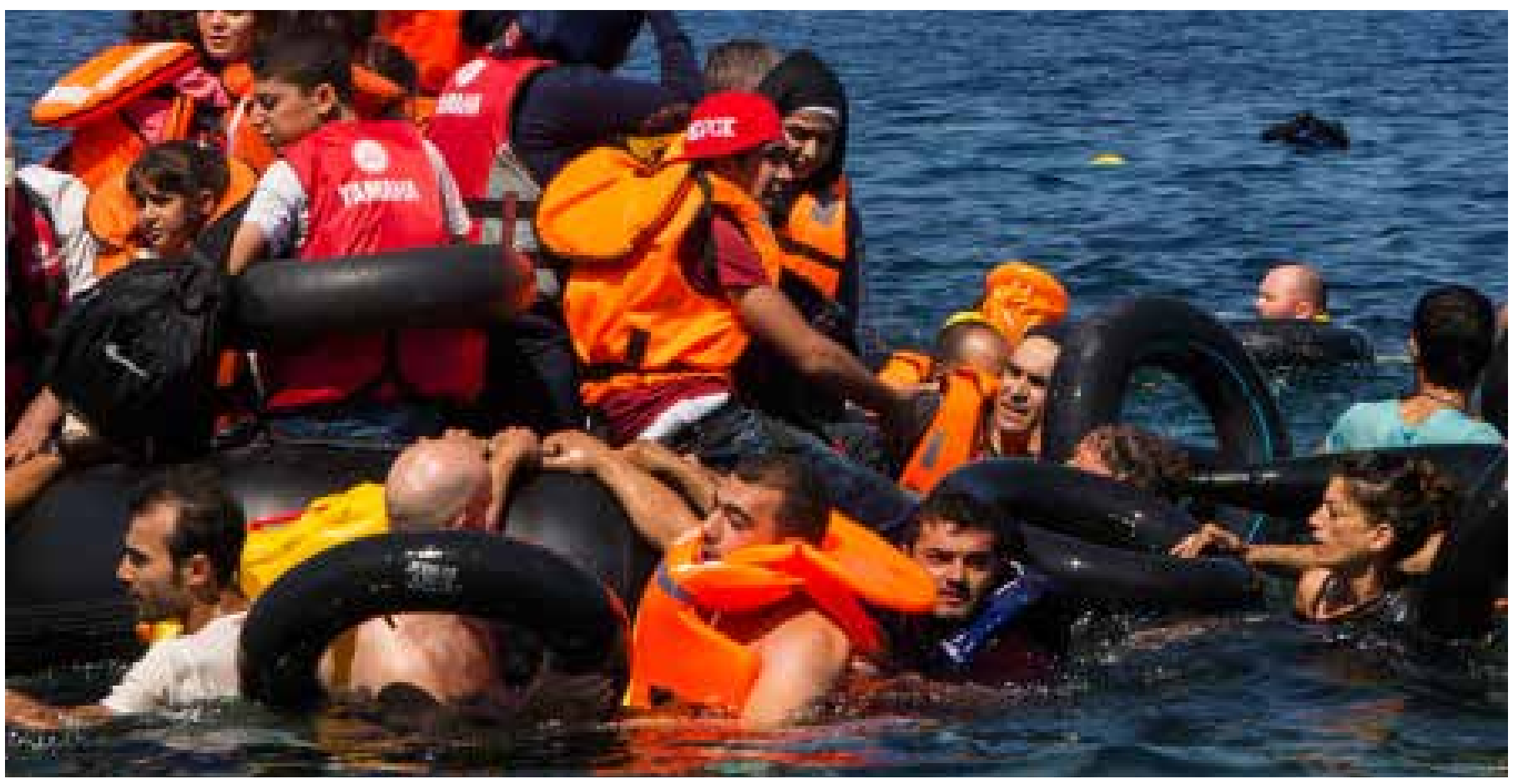




\section{O antes e o agora de um país em guerra}

Imagens por ordem de aparição

1. Antigo mercado de Alepo

2. Castelo de Alepo

3. Porta da Vitória

4. Praça exterior na frente da grande Mesquita Omíada

5. Grande Mesquita de Omíada

6. Hotel Carlton em frente ao Caste-

lo de Alepo

https://www.digitalrev.com/article/before-and-after-

-photos-show-the-impact-of-war-in-syria Acesso em 02 de janeiro de 2019 


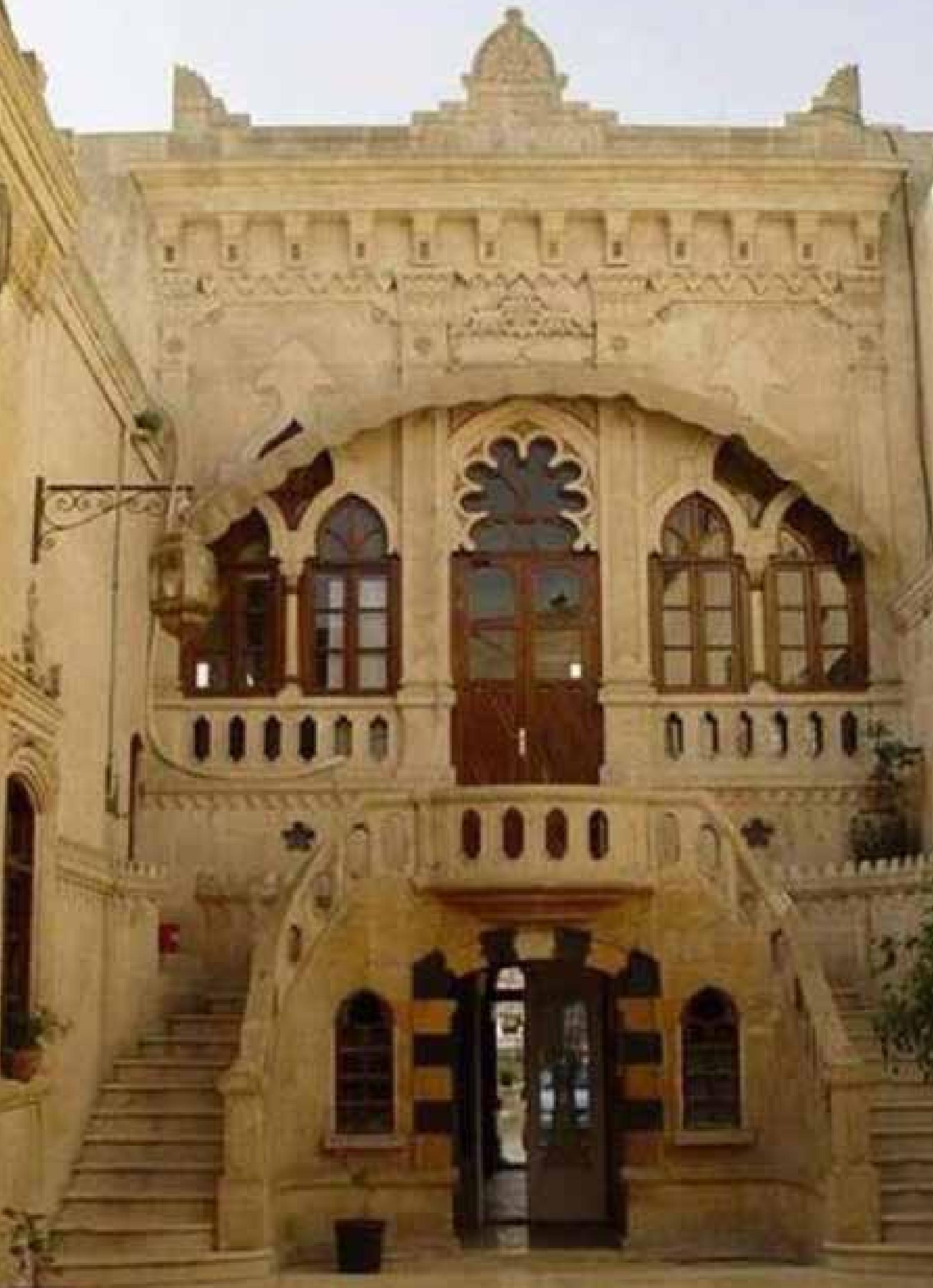



6

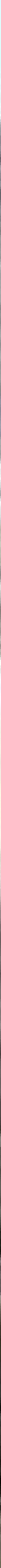





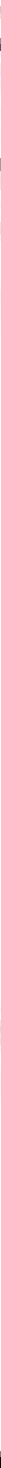

8. 32

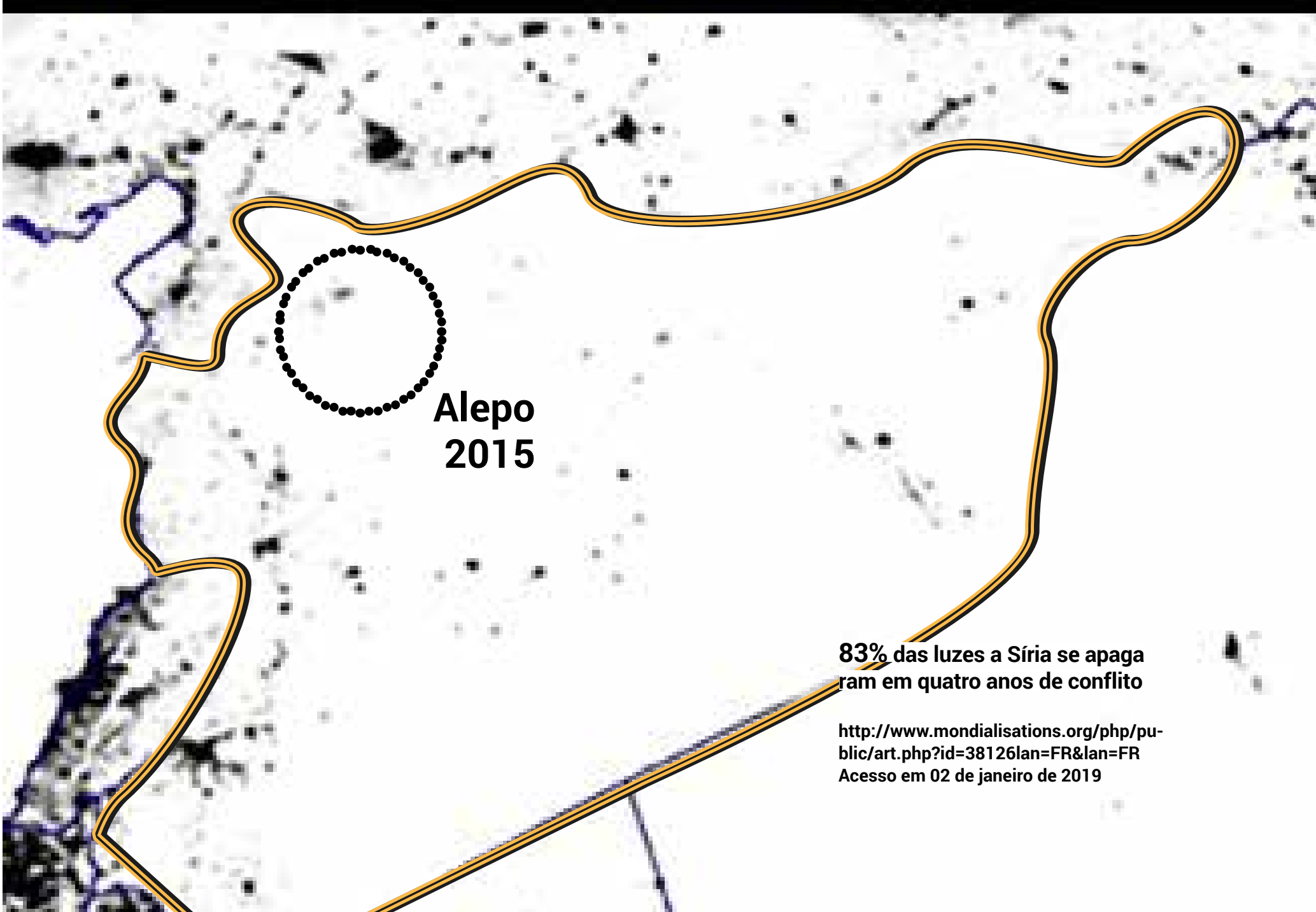





\section{IMIGRAÇÃO, COMPLEXIDADE E DESIGN}


Aqui, nesse ponto da investigação, a pergunta que ao longo de todo o estudo permaneceu como pano de fundo para a elaboração e desenvolvimento da pesquisa, se estrutura agora com maior clareza, ainda que sujeita a transformações e ajustes, em uma linha de palavras encadeadas para tornar o texto a seguir uma resposta, também aberta e sujeita a transformações e ajustes. Se pergunta então, de que maneira o design pode agir, reagir e aprender com problemas complexos? Sob a pergunta está a questão da migração internacional Síria, situada pela perspectiva do design entendido como um processo, uma abordagem ou uma teoria para se pensar e projetar soluções para problemas complexos, neste caso com uma dimensão de crise humanitária.

O campo do design se encontra constantemente sob pressão em busca de respostas a problemas, sejam estes simples e/ou complexos como os que surgem num mundo cada vez mais em transformação. Em contextos que aparecem como uma espécie de ecologia de problemas, algumas vezes se tem a impressão de que há um esgotamento de respostas dentro da teia conceitual própria do campo. Esta constatação, que não é de hoje, faz com a carga conceitual e processual do design se apresente de forma dinâmica e aberta a trocas com outros campos e áreas de conhecimento.

Dentro desse ambiente de intercâmbio com outros campos surgiram contribuições significativas oriundas da computação, da engenharia, da biologia da administração, entre outros. Junções que acontecem em decorrência do reconhecimento da necessidade de um processo interdisciplinar e ampliado, que envolva não só profissionais, mas também colaboradores com perfis distintos.

Evidentemente, que com essas e com outras interlocuções, surgem atualizações que estimulam e criam ambientes para que novas concepções, metodologias e elaborações teóricas despontem. Tais inovação ou heterodoxias 
44 Expressão cunhada pelo sociólogo americano Robert K. Merton em referência a uma abordagem da Sociologia que embasa a pesquisa empírica para processos de abstração e elaboração de enunciados gerais, passíveis de serem verificados por dados.

Niklas Luhmann, (2010, p.35) ao se consolidarem, de novo podem ser superadas por outros modos de construir num processo contínuo que torna o design um campo cuja eficácia se baseia num saber que não cabe em si.

Neste sentido, é compreensível que uma parte significativa do design tenha como fundamentação em seus processos teorias de médio alcance (middle range) ${ }^{44}$, em particular em suas pesquisas empíricas. Teorias que, diferentemente da ciência clássica, são capazes de lidar com problemas de uma sociedade que, em geral, se configuram por uma diversidade de origens, com grande quantidade de detalhes e, muitas vezes, intangíveis. Problemas que envolvem pessoas, comportamentos, relações interpessoais e de grupos, sentimentos, ambientes etc.

Em Imigração, Complexidade e Design há um esforço em contribuir com esse processo de expansão de conhecimento, abordagens e desenvolvimento de projeto. Os estudos da complexidade e da teoria dos sistemas - como arcabouço teórico inicial, associado à perspectiva projetual inerente ao design - se apresentam, neste estudo, como modos de entendimento e de ação diante de realidades multifacetadas como às do fenômeno da imigração, concebido como crise humanitária, marcado por rupturas profundas desdobradas em caminhos imprevistos.

Os elementos históricos, que antecederam este capítulo, foram fundamentais para o estabelecimento de relações entre dados do passado e do presente. A seguir, será realizada uma reflexão sobre o fenômeno da imigração de sírios na cidade de São Paulo em busca tecer relações em torno dos movimentos dessa população à luz de conceitos e princípios da complexidade, sob o enfoque de sistemas. 


\section{1 \\ CARACTERIZANDO O SISTEMA DA IMIGRAÇÃO}

Uma das principais contribuições da teoria dos sistemas foi a proposição de que o mundo se organiza através de sistemas mais ou menos complexos, numa perspectiva que coloca em jogo arranjos e configurações estruturadas a partir de processos também mais ou menos complexos. Em linhas gerais, um sistema se caracteriza como um conjunto de elementos interconectados que desenvolvem atividades em busca de um objetivo final comum, processo que pode ser referido como um todo organizado. Essa definição permite afirmar que desde as moléculas até o universo podem ser concebidos como sistemas, muitos dos quais, conectados e sustentados por redes de interações.

Sobre a generalização da ideia de sistemas, Bertalanffy ressaltou que, 
Existem modelos, princípios e leis que se aplicam a sistemas generalizados ou suas subclasses, qualquer que seja seu tipo particular, a natureza dos elementos que os compõem e as relações ou "forças" que atuam entre eles. Parece legitimo exigir-se uma teoria não dos sistemas de um tipo mais ou menos especial, mas de princípios universais aplicáveis aos sistemas em geral. (1968, p. 57)

Diante disso, embora sistemas sejam organizações que possuem especificidades que os diferenciam, como sistemas abertos e fechados, biológicos e artificiais, simples e complexos etc., são conformações que possuem aspectos comuns e, portanto, passíveis de serem observados por uma teoria geral.

42 Daniel Christian Wahl

é consultor e educador internacional especializado em design de sistemas inteiros de inspiração biológica e inovação transformadora.

O biólogo e cientista de sistemas, Daniel Christian Wahl ${ }^{42}$ (2019) reforça que o estudo de qualquer sistema deve ser precedido por uma pergunta fundamental: "qual é o sistema em questão?” De acordo com ele, é a partir da resposta que se pode definir os "limites que nos dão as restrições necessárias para permitir dar sentido à situação" (2019, p. 101). Uma característica importante de sistemas, incorporado pela afirmação de Wahl, é o conceito de "situação", que está relacionado ao transitório, ao que está sujeito às circunstâncias do momento. $\mathrm{O}$ sistema poderia ser definido, por conseguinte, em função da sua circunscrição no tempo e no espaço.

Em se tratando da imigração de sírios na cidade de São Paulo, um dos sistemas a ser tido como marca do fenômeno é o do espaço social definido como um tipo de organização complexa, com estruturas dinâmicas que evoluem por processos de ruptura, emergência e adaptação: como as pessoas, organizações, leis, política, saúde pública, economia, educação etc. 
Luhmann (1995) em seus estudos sobre sistemas sociais, atribui sua complexidade a uma de suas características principais, através da qual é possível compreender uma das marcas da sociedade moderna: eles são o resultado de uma interconexão de subsistemas diversos (religião, economia, política, educação, legislação, ciência), que desempenham funções diferenciadas dentro de um ambiente de interdependências.

Um aspecto importante sobre sistema social pela perspectiva de Luhmann, é que ele o define como um sistema fechado, do ponto de vista de suas operações internas, o que significa que não sofre influências do meio em relação ao modo como realiza suas operações. Essa noção difere da de outros teóricos que também pensam a sociedade pelo viés de sistemas, como a de Talcott Edgar Frederick Parsons ${ }^{43}$, mas que a concebem como aberto, no qual há influências mútuas entre sistemas e entre estes e ambiente.

Parsons considera o funcionalismo estrutural um instrumento analítico para se conhecer, pensar e descrever a sociedade, considerada, por ele, um sistema estruturado em quatro subsistemas: o social, o político, o econômico e o cultural, "estruturas a partir das quais seria possível perguntar quais funções seriam necessárias para sua preservação e manutenção" (apud LUHMANN 1995, p.37). Para Luhmann, este é um preceito que possui uma séria implicação, por se configurar como uma abordagem rígida sobre um objeto fluído. Adotando uma posição crítica em relação a Parsons, ele afirma que além de não ser possível perguntar qual função da própria estrutura, também não tinha sentido ir além com a técnica da decomposição.

O preceito, praticamente axiomático, de que toda orientação de análises concretas deveria estar dirigida por estruturas

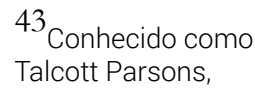

Foi um sociólogo norte-americano, representante mais destacado da teoria denominada Estrutural-Funcionalismo em decorrência de sua reformulação sobre o conceito de sistema social.

Fonte: https://www.ebiografia.com/talcott_parsons/

Acesso em 05 de dezembro de 2018 
supostamente invariáveis, impunha, de início, sérias limitações teóricas; além de ficar claro que tal desenvolvimento teórico tinha dificuldade de integrar fenômenos que se descrevem, geralmente, com o conceito de desvio: disfunções, criminalidade, condutas desviantes. (LUHMANN, 1995, p. 37)

44 Autopoiese: do grego auto "próprio", poiesis "criação", conceito que define a capacidade dos seres vivos de produzirem a si próprios a partir de processos autoreferenciados.
Luhmann se baseia na teoria da Autopoiese ${ }^{44}$, dos biólogos chilenos Maturana e Varela, e por ela, tipifica o sistema social tal qual os biólogos denominam os sistemas vivos biológicos: como sistemas fechados. Não porque sejam incomunicáveis e indiferentes ao ambiente, mas sim porque operam sob suas próprias determinações. Segundo Léo Peixoto Rodrigues e Fabrício Monteiro Neves, o fechamento é ao mesmo tempo, "a condição da abertura do sistema ao ambiente: o sistema só é capaz de estar atento e responder à causalidade externa por meio das operações que ele próprio desenvolveu" (2012, p. 79). Isso significa que, sistemas sociais realizam trocas com outros sistemas e com o ambiente, porém, suas operações internas acontecem sob o que está posto por seu próprio limite de operação.

Em termos de organização, o fenômeno da migração se caracteriza como complexo por estar inserido em um ambiente altamente interconectado, o mundo e seus sistemas, e também porque, enquanto sistema, possui uma diversidade de subsistemas, que por sua vez, são também de natureza complexa e se relacionam a partir de uma estrutura em rede, com distintas tipologias e se sobrepondo umas as outras, dentro de um equilíbrio dinâmico. Isso ocorre com os problemas capciosos, com os quais o design necessita lidar, e que surgem da interação de sistemas distintos com tendência ao crescimento por estarem inseridos em uma cadeia de eventos causais com ciclos de retroalimentação. Como um problema econômico que afeta o sistema de saúde que, por sua vez, afeta o sistema familiar etc. 
O fenômeno da migração síria se evidencia por meio da manifestação de alguns processos característicos dos sistemas complexo, como a diversidade de origens da crise (política, econômica, social, ideológica etc.), que deu início a uma série de conflitos armados entre grupos organizados (sendo os principais os rebeldes, os curdos, o estado islâmico e as forças armadas da Síria e mais uma média de 230 associações de milicianos) ${ }^{45}$, provocando o êxodo de mais de um terço da população (dados de 2017), que se distribuiu por diversos lugares do mundo, principalmente após o fechamento de algumas fronteiras de países europeus.

No Brasil, um dos impactos da crise se manifestou no salto do número de reconhecimento de refugiados entre os anos de 2007 e 2017, período que engloba parte do conflito na Síria. Por muitos migrantes terem suas entradas barradas em outros países, o fluxo que antes se concentrava em países europeus passou a se distribuir por outros que, de um modo ou de outro, facilitavam suas entradas. Este movimento, na perspectiva de sistemas complexos, se caracteriza como um dos padrões distintivos desse tipo de sistema, que é a emergência.
45 Fonte: http://www.kiaunoticias.com/ destaque/entenda-a-guerra-na-siria 


\section{IMIGRAÇÃO E FRONTEIRAS}

Entre a diversidade de aspectos que envolvem o processo de migração, um dos mais importantes é o das fronteiras. Sim, fronteiras no plural, porque em um sentido mais amplo da palavra, não se passa ou tenta passar por uma, mas por várias. Entre elas, as internas do sujeito migrante e aquelas que a ele são postas de modo concreto ou imaterial.

Segundo Agier, fronteiras em geral são resultados, e "por vezes ainda o objeto, de uma negociação política, de uma guerra, de uma separação, ou de uma conquista" (2015, p. 39), passíveis de mudar de forma radical com o passar do tempo, como aconteceu com a construção e queda do muro de Berlim que, após 30 anos de sua construção, foi ao chão por uma nova concepção política e social. Fronteiras podem ser manifestações materiais e imateriais, que emergem de processos culturais, quando em contexto de sociedade.

Sobre o sentido dos conceitos, Agier diz ser importante atualizar aqueles "com os quais pretendemos descrever e compreender o mundo que nos cerca" (2015, p. 39). Um mundo que, desde sempre, esteve em transformação e, com ele, aquilo que o caracteriza como um ambiente: os seus diversos sistemas.

A fronteira, além de desempenhar um papel geopolítico, possui também a dimensão humana, que para ser percebida, segundo Agier, necessita que a diversidade, de momentos e lugares em que acontece, seja alargada con- 
sideravelmente para além dos limites postos por Estados-nação. Agier denomina de "situações de fronteira" (2015, p. 39) abordagens que abrangem o conceito por esse viés. Do mesmo modo, aqui serão tratadas as fronteiras, como situações que ora se caracterizam como construções geopolíticos, ora como barreiras que se impõe à diversidade de operações internas do sujeito, como a da língua, da cultura, da religião etc.

Um dos principais argumentos de Agier sobre a fronteira se refere ao que ele denomina "o rito da fronteira", que "testemunha a instituição de toda vida social, num dado ambiente", determinando "a separação e a relação com o mundo natural e social que o cerca" (2015, p. 42). Nesta concepção, ele coloca a fronteira como lugar que divide e permite relação, uma definição muito aproximada da visão da relação entre sistema e meio, agenciada pelo Acoplamento Estrutural.

Em fenômenos como o da migração, que envolve pessoas, a fronteira necessita ser definida antes de sua concepção como muro, realizado, congelado e absoluto como "em vias de se formar", justificando que ela realiza uma dupla ação: interna e externa. Ao estabelecer um limite entre um e outro faz com que um exista diante do outro. Assim, a fronteira é também um lugar de afirmação e de reconhecimento do outro.

As falas de Oula e Ahmad estão em sintonia com as de muito refugiados que deixaram a Síria, e também com as de outros, que foram forçados a sair de seus lugares. Há muita perda, embora se ganhe a manutenção da vida. Há um passado vivido, uma vida construída, relações de diversas ordens que de um momento para o outro ficam para trás. Deixá-los requer que se ultrapasse a barreira emocional, o que torna ainda mais complexa a tarefa de organizar a saída. Em outras palavras sobre o dito por Ahmad, não há muito espaço para sonho quando muito do que se tem está desmoronando. 
Ahmad Al Hraki ,- 30 anos

Sírio, refugiado no Brasil

"Pra mim, a experiência de mudar

pra outro país era tão, tão preocu-

pante. Quando eu saí da Síria pra

Turquia eu não coloquei muitos

sonhos"
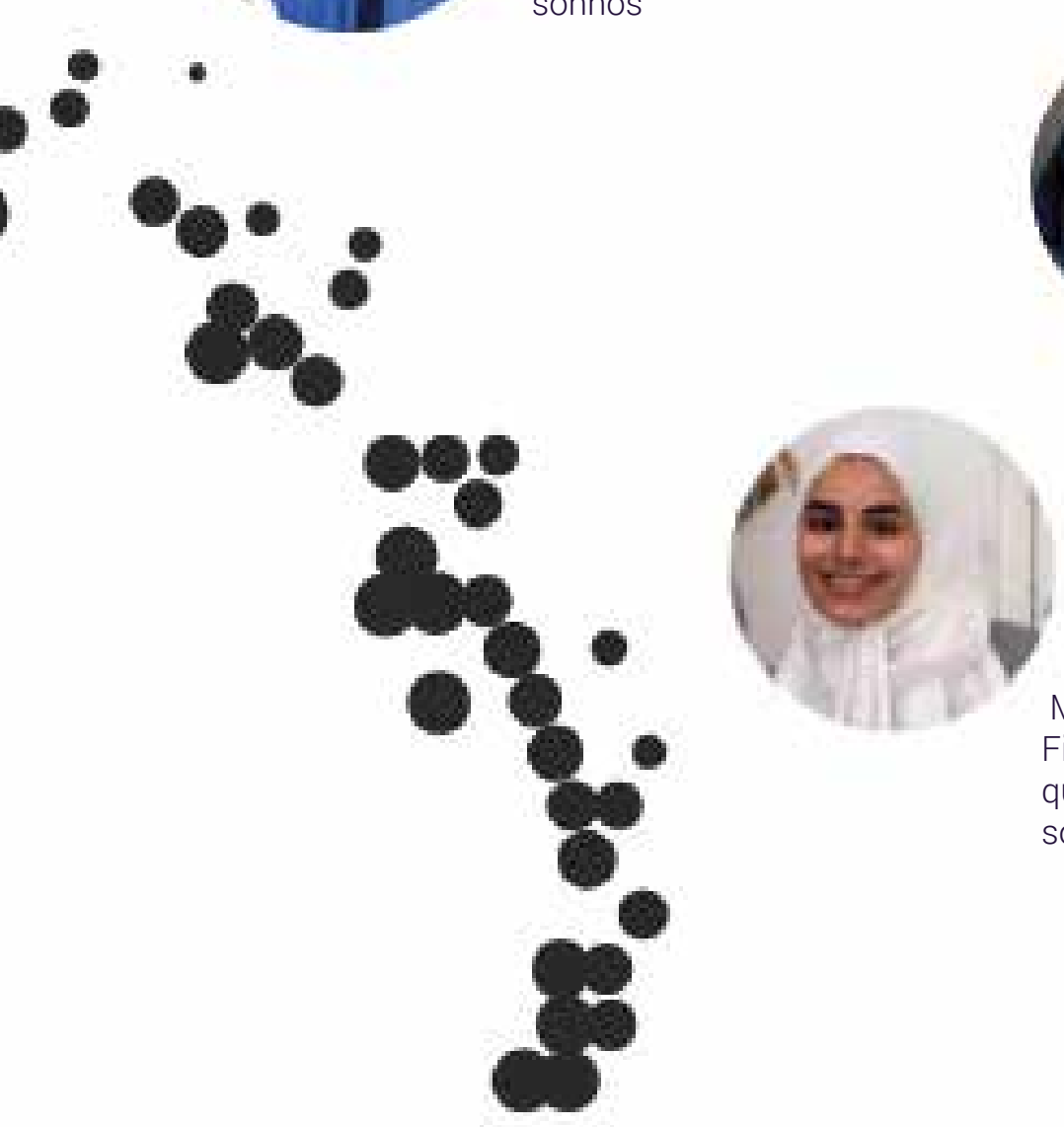

Muna: "tenho orgulho do meu véu"

Filha do meio de Yusra, sobre o bullyng que sofreu na escola e o difícil processo de adaptação no ambiente.

Oula al-Saghir -36 anos

Palestina, residente na Síria e refugiada no Brasil

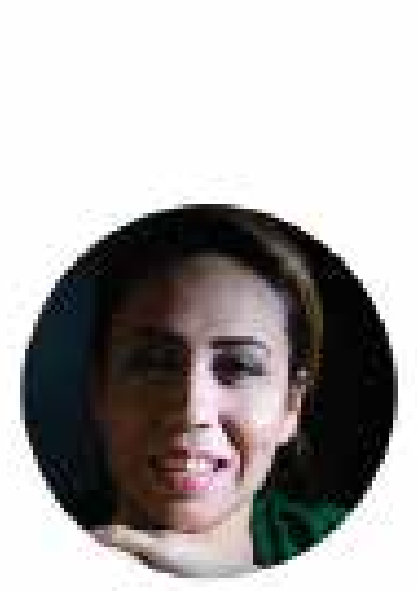

"eu tava muito feliz, minha vida tava normal, com calma, alegria. Eu estudei, casei, trabalhei, tenho amigos, tenho família, tenho casa, tenho esperança, tenho sonhos, tenho muitas coisas. Hoje, eu três anos aqui no Brasil, e hoje também, passou sete anos da guerra da Síria. Eu perdeu tudo, eu mudei toda minha vida, mudei pra cá"

Consegui revalidar diploma depois de um ano e cinco meses, já revalidei.

Depois entreguei o documento pro CREA (ConseIho Regional de Engenharia e Arquitetura). CREA ficou 11 meses e foi indeferido. Faz um mês que

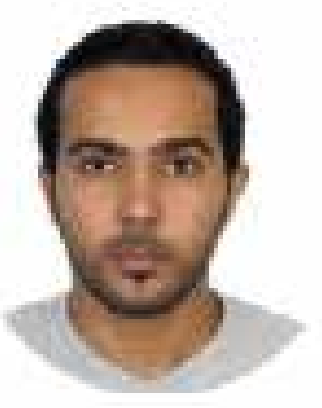
me entregou o documento que foi indeferido. Eles estão precisando de um documento que eu não vou conseguir trazer da Síria." (4:18) Mohamad Aldrwich (engenheiro de petróleo) 
Agier explica que a fronteira se realiza em três dimensões relativas as quais "convém preservar e as quais devemos verificar o lugar caso a caso: a do tempo, do mundo social e do espaço" (2015, p. 43).

Por temporal se entende que antes da fronteira, tanto a comunidade quanto o lugar já existiam e assim, ela assume uma relatividade entre o antes e o depois que permite conjeturar que poderia ou não ter existido. Neste sentido Agier diz que "será eficaz, portanto, simbolicamente, lembrar o evento e o compartilhamento do tempo que o realizou" (2015, p. 43). A sua formação então se localiza dentro de uma cadeia de eventos nos quais se compartilha, entre outras coisas, o tempo. Para muitos refugiados sírios, em menor ou em maior grau, deixam para traz um passado significou transpor a existência de uma fronteira até então ausente.

Sob uma dimensão social, a fronteira se estabelece como o divisor simbólico, o começo de um grupo estabelecido como o de dentro do ambiente e o limite do outro, o de fora. Isto significa que "a aproximação - e, além disso, o quadro relacional representado pela própria fronteira - é necessária para o duplo reconhecimento, de si e do outro". E por fim, a fronteira como dimensão espacial se caracteriza como tal porque, segundo Agier, "tem uma forma que recorta o espaço e materializa um dentro e um fora." Uma separação que mesmo não sendo materializada por uma edificação, "nunca é apenas uma metáfora", finaliza (2015, p. 43).

Em termos de fronteira política, o Brasil é um dos países a fazer parte da Convenção das Nações Unidas e tem assinado importantes tratados internacionais de direitos humanos: o Estatuto dos Refugiados, protocolado em 1967, promulgando em 1997 - a lei de refúgio (9.474/97) - , que contempla tanto os instrumentos adequados à realidade do território nacional quanto aqueles praticados 
${ }^{46}{ }_{\text {Fonte }}$ http://www.justica.gov.br
/seusdireitos/refugio/anexos/resolucao-
-normativa-n-17-do-conare.pdf/view

Acesso em 12 de janeiro de 2019
47 http://www.in.gov.br/materia/-/asset_publisher/Kujrw0TZC2Mb/content/ id/19297025/do1-2017-09-18-resolucao-normativa-n-25-de-14-de-setembro-de-2017-19296756 internacionalmente, como a definição de refugiado da Declaração de Cartagena (1984), que considera de modo generalizado aqueles sob situação de violação de direitos humanos. Esta definição foi incorporada pela lei brasileira em sua caracterização ampliada.

O crescimento da chegada de sírios no território brasileiro se deve, e muito, a ações de facilitação que país empreendeu em relação a crise. Uma delas, é a facilitação da emissão de visto para as vítimas envolvidas geograficamente com conflito, e também para aqueles situados em regiões de fronteira com o país. Em resolução normativa 17/ 2013 pelo CONARE ${ }^{46}$ - Comitê Nacional para os Refugiados, ficou estabelecido que:

Artigo $1^{\circ}$ Poderá ser concedido, por razões humanitárias, o visto apropriado, em conformidade com a Lei $\mathrm{n}^{\circ}$ 6.815, de 19 de agosto de 1980, e do Decreto 86.715, de 10 de dezembro de 1981, a indivíduos afetados pelo conflito armado na República Árabe Síria que manifestem vontade de buscar refúgio no Brasil. Parágrafo único: Consideram-se razões humanitárias, para efeito desta Resolução Normativa, aquelas resultantes do agravamento das condições de vida da população em território sírio, ou nas regiões de fronteira com este, como decorrência do conflito armado na República Árabe Síria (BRASIL. Resolução Normativa n. 17, de 20 de setembro de 2013).

Esta resolução foi renovada pelo governo brasileiro no ano de 2015, e posteriormente em 2017 prorrogada até setembro de $2019^{47}$.

"O alto número de refugiados que o conflito na República Árabe Síria continua a gerar; a necessidade de que pessoas afetadas pelo conflito na Síria possam realizar um deslocamento seguro para solicitar refúgio no Brasil" (Imprensa Nacional, 2017). 
Essas medidas foram, para muitos dos refugiados sírios, um fator atrator para a vinda para o Brasil, uma abertura que para muitos que haviam tentado o refúgio em outros lugares. É comum que, após terem suas solicitações negadas, a facilidade e agilidade no processo de migração para o Brasil faz com que o país se torne o destino escolhido. Assim como muitos dos imigrantes do primeiro fluxo, que não tinham ideia de como seria a vida no Brasil, os novos imigrantes sírios também não têm isto muito claro.

Por uma perspectiva sistêmica, a fronteira é um dos principais aspectos da complexidade entre sistema e ambiente e se caracteriza no caso de sistemas sociais, justamente pela ausência de contornos e limites definidos entre ambos. A fronteira é uma abstração com a qual se deve lidar em estudos sobre sistemas, no âmbito das relações sociais que, devido ao seu modo de organização e complexidade, ocorre sob condições distintas de intercâmbio, visto que está sujeita a interrelação de fatores variados (contexto, indivíduo, causa, tempo etc.).

Segundo Vasconcellos, as fronteiras não são sistemicamente concebidas como barreiras, mas sim como "lugar de relação" ou o "lugar das trocas" entre sistema e ambiente (2015, p. 207). Morin diz que isolá-los seria "criar in vitro um isolamento puramente determinista" (1996, pg. 202), alheio à realidade da relação sistema-ambiente, a qual se realiza pela passagem da fronteira. Assim, complementando a observação de Morin, no estudo da relação entre sistema e ambiente, há de se contemplar também as possíveis dimensões de suas fronteiras.

Ao se erguer uma fronteira, seja ela natural, política, social, econômica, religiosa etc., se obtém um estado de separação, onde de um lado está construída a ideia de um invasor, um perigo, um forasteiro, um estranho, e do outro, aquele a ser protegido de possíveis abalos que possam vir com aquele que entra e, com isso, surja o temido caos, 
o desequilíbrio que rompe com a ordem e provoca mudanças imprevistas, como aconteceu em alguns países europeus com a chegada, ou passagem, de migrantes sírios por seus territórios. O que decorreu dessa situação foi uma sucessão de eventos que não passaram desapercebidos ao contrário provocaram uma ação que se pautava, principalmente, pelo descaso.

Desde que os migrantes sírios iniciaram sua saída do país, tanto pelas rotas terrestres, quanto pelas marítimas, a potência do corpo se expressou como forma de resistência, de limitação e de superação de fronteira. Seja na relação do corpo com outros corpos, seja com o Estado, seja com ele mesmo. Diante dessas fronteiras, muitos corpos sucumbiram aos sucessivos desafios que o caminho entre a partida e a chegada impõe. Muitos chegaram onde queriam, muitos onde nem imaginavam que um dia viveriam.

\section{3}

\section{O AMBIENTE, O IMIGRANTE E SUAS RELAÇÕES}

Em 2013, o Brasil começou a receber um maior número de migrantes sírios, em função se reconhecê-los como vítimas e concedê-los, além do visto humanitário, o estatus de refugiados. A partir desse marco, a quantidade de imigrantes no país, especialmente em São Paulo, começou a crescer e a emergir algumas evidências dessa presença, distribuída por bairros, ruas e, progressivamente, ocupan- 
do lugares de moradia, de estudo, de trabalho, de entretenimento e de voz.

Esses sujeitos chegam de modo distinto que seus compatriotas do início do século 20 , que vieram em busca de crescimento econômico. As viagens de navio dão lugar às de avião e, como motivo comum, têm a necessidade de sair de um ambiente de risco de morte para entrar em um que lhes permita viver e se desenvolver.

Além do visto previsto em decreto, o governo brasileiro dispensa a exigência de documentos, por entender que muitos tiveram suas casas destruídas e com elas, essas comprovações. Embaixadas brasileiras, em países vizinhos da Síria, foram orientadas a emitir o visto de viagem para todo cidadão vítima do conflito que o solicitasse.

O refugiado sírio Kinan Bakkour relata que esse foi o motivo de sua decisão pelo país.

"Eu escolhi o Brasil porque o Brasil nos respeita como sírios, como natureza humana. Nós viemos para o Brasil por meio de um visto normal, um passaporte normal. Nós viemos de avião. Nós não precisamos vir para cá de barco, no mar, como outros sírios foram para a Europa e se afogaram no mar, como vocês sabem. Este é o porquê de eu ter escolhido o Brasil.” (0:07)

Para Bakkour, este tratamento recebido fez com que se sentisse reconhecido e aceito como uma pessoa que pode integrar o ambiente social do país destino. Ele complementa dizendo que "Eu me sinto parte da sociedade" (0:49). Por motivos similares Kamal Daqa ${ }^{48}$, que era gerente de TI na Síria, destaca que dos três países que concedem o visto humanitário para sírios (Malásia, Turquia e Brasil), somente o Brasil os beneficia com a possibilidade de permanecer por um longo tempo sem a necessidade de renovar constantemente o documento e que, princi-
48 Kinan Bakkour Documentário: Refugiados Sírios em São Paulo, 2017 https://www.youtube.com/watch?$\mathrm{v}=\mathrm{YXWSSLSFUYM}$

Acesso em 07 de julho de 2018 10 Kamal Daqa Reportagem: Sírio em São Paulo, 2015 https://www.youtube.com/watch?$\mathrm{v}=\mathrm{iMHt}-\mathrm{WAnhnU}$

Acesso em 07 de julho de 2018 
49 Fonte: https://www.acnur.org/portugues/2013/09/27/acnur-parabeniza-brasil-por-anuncio-de-vistos-humanitarios-para-sirios/ Acesso em 09 de novembro de 2018 palmente, lhes permite trabalhar e estudar, o que facilita a busca por autonomia e crescimento.

A segunda etapa de regularização se realiza ao entrar no Brasil: o pedido de refúgio lhes concede, com base no Art. $6^{\circ}$ da Lei $\mathrm{N}^{\circ}$ 9.4742, de 22 de julho de 1997, o "direito, nos termos da Convenção sobre o Estatuto dos Refugiados de 1951, a cédula de identidade comprobatória de sua condição jurídica, carteira de trabalho e documento de viagem."

A cidade, que os recebe hoje, não é mais a que recebeu os seus compatriotas. Atualmente, São Paulo tem a maioria dos quase três milhões de brasileiros com ascendência síria ${ }^{49}$, pais, avós e bisavós que chegaram no passado com a sua cultura e contribuíram ao longo do tempo com o crescimento e fortalecimento da comunidade sírio-libanesa, hoje parte da história da cidade. Nesse contexto, os imigrantes atuais chegam com a possibilidade de encontrar alguns marcadores com os quais podem se identificar, como grupos sociais relacionados a sua cultura, sinagogas, restaurantes, comércio de produtos sírios etc.

A chegada ao aeroporto internacional de São Paulo é para muitos o ponto final de um longo caminho, que sem exceção praticamente, tem início em países próximos a Síria, como a Turquia, Líbano e Palestina. A escolha da cidade de São Paulo entre tantas no Brasil, se justifica pelas possibilidades que chegam aos ouvidos dos que buscam por refúgio. A principal delas, ser uma das cidades mais importantes da América Latina em vários aspectos, entre eles o da dimensão econômica que, para muitos, é fundamental, na medida em que necessitam recomeçar a vida e a conquista de um trabalho. 
Acesso em 12 de março de 2019

180 FAUUSP TESE DE DOUTORADO MIGRAÇÃO, COMPLEXIDADE E DESIGN 


\section{População da Economia}

cidade de

\section{São Paulo}

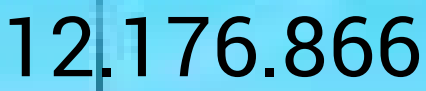

São Paulo - cidade e estado https://cidades.ibge.gov.br/brasil/sp/sao-paulo/panorama

Acesso em 25 de fevereiro de 2019

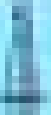

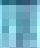

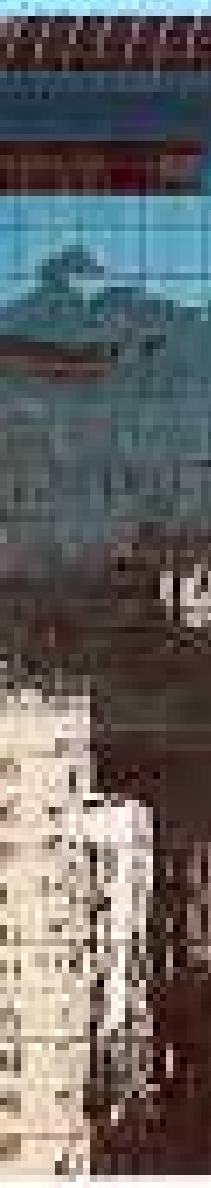

Universidades públicas do

Estado de São Paulo

Estaduais

USP-Unversidade de SAo Pavio

UNESP - Unversidado Estadal Pavista

UNCAMP - Unwersidade de Campinas

Federais

UFABC - Unversidade Federal do $A B C$

IFSP-hstuto Foderal Sto Pavo

UFSCar - Unhworsidude Fodoral do Salo Carkos

UNFESP - Unviversidade Federal don Sto Pado

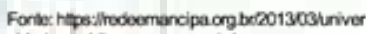
sidades-publica-om-sao-paulo

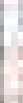

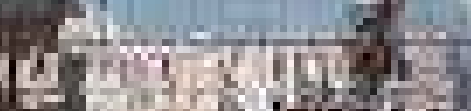

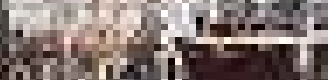

ant

itit:

19t

Ai

HI

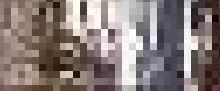

(1)

et
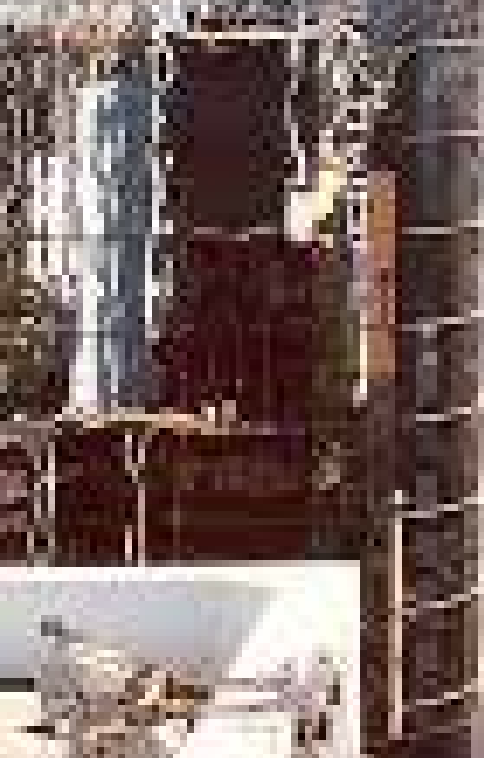

.
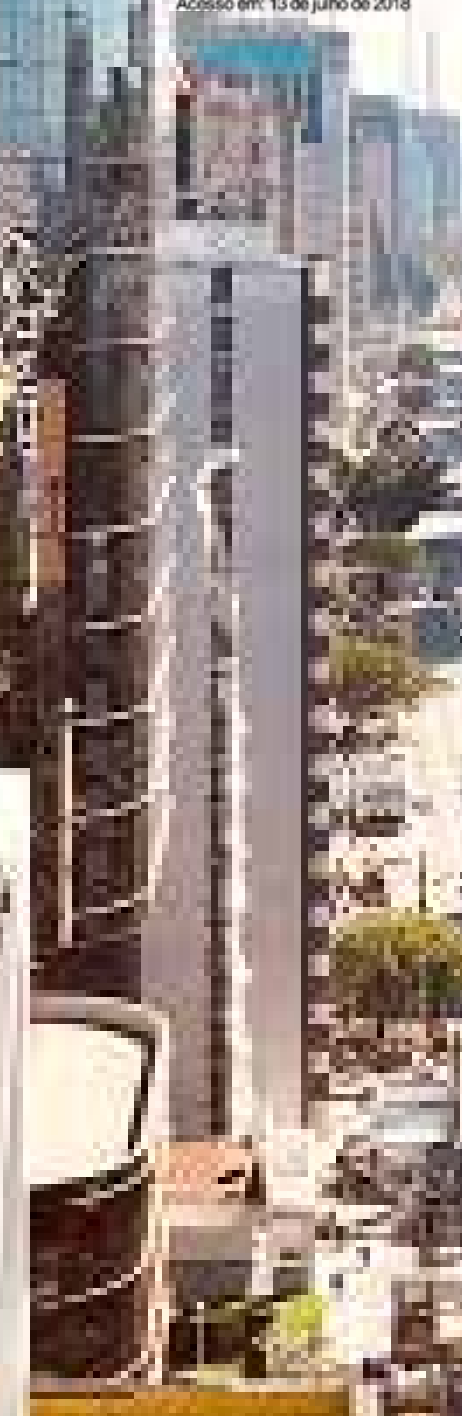

representava mais que o dobro da segunda maior capital, o Rio de representa $109 \%$ da soma do PIB de todas as capitais dos Estados

tem-economia-mais-solida-do-pais

Estmativa do ano de 2016

hittp:/Wwwnewgeography.comviles/cox-wua-16-3.jpg
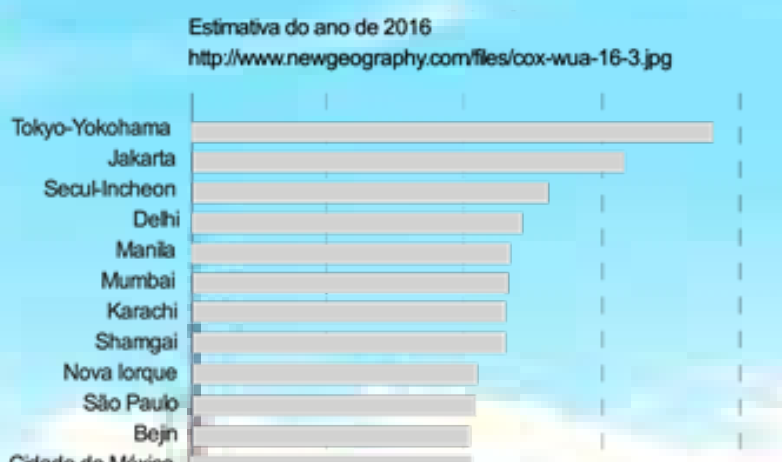

Cidade do Mérico 


\section{Prefeitura de São Paulo ${ }^{50}$}

2014 - Criação do Centro de Referência e Acolhida para Imigrantes, o CRAI, com o objetivo de garantir os direitos do imigran-te, tanto legais, quanto humanos. Local: Bairro da Bela Vista.

2018 - Programa Clube Amigo do Refugiado ${ }^{51}$. Parceria entre a prefeitura e a ACNUR para oferecer juntamente com a Secretaria Municipal de Esportes e Lazer (SEME), atividades de integração a refugiados por meio da prática esportiva.

\section{Governo do Estado}

2014 - Casa de Passagem "Terra Nova"52. Com funcionamento 24 horas oferece apoio jurídico, social, psicológico e atividades pedagógicas, de vivência e culturais. Tem como população atendida as vítimas de tráfico de pessoas e solicitantes de refúgio. Local: Bairro da Bela Vista.

2014 - Centro de Integração da Cidadania (CIC) ${ }^{53}$. Com o objetivo de orientar imigrantes sobre seus direitos básicos. Local: Centro de São Paulo.

\section{Governo Federal}

2015 - Primeira prorrogação pelo CONARE ${ }^{54}$, por mais dois, da medida que facilita a concessão de visto à refugiados sírios. Em 2017 este ato se repetiu, prorrogando a resolução por mais dois anos.

2016 - Estabelecimento da Resolução Normativa n.23/2016, que torna regulamentadas atividades relacionadas a viagens internacionais de refugiados e solicitantes de refúgio ${ }^{55}$.
50 Fonte: https://www.prefeitura. sp.gov.br/cidade/secretarias/direitos_humanos/migrantes/crai/ Acesso em 13 de maio de 2018

51 Fonte: http://www.capital.sp.gov. $\mathrm{br} /$ noticia/prefeitura-lanca-programa-clube-amigo-do-refugiado-para-incentivar-pratica-esportiva Acesso em 13 de maio de 2018

${ }^{52}$ Fonte: http://www.saopaulo. sp.gov.br/spnoticias/oportunidades-em-sp-refugiados-da-casa-de-passagem-terra-nova-conseguem-emprego/

Acesso em 13 de maio de 2018

${ }^{53}$ Fonte:

http://www.justica.sp.gov.br/ Acesso em 13 de maio de 2018

${ }^{54}$ Fonte: http://repositorio.unicamp. br/bitstream/REPOSIP/332529/1/ Quinaglia_MariliaCalegari_D.pdf Acesso em 09 de outubro de 2018

${ }^{55}$ Fonte: http://www.planalto.gov. br/ccivil_03/_ato2015-2018/2017/ lei/L13445.htm Acesso em 09 de outubro de 2018 
2017 - Sancionamento da Lei de Migrações, No $13.445 / 2017$, que "dispõe sobre os direitos e os deveres do migrante e do visitante, regula a sua entrada e estada no País e estabelece princípios e diretrizes para as políticas públicas para o emigrante”.

Segundo Quinaglia, "os documentos que tangem a temática do refúgio estão voltados prioritariamente para a questão da entrada e reconhecimento dos refugiados no Brasil" tendo portanto um papel de instância de "regulação imigratória", mas, em relação ao tema do acolhimento, o faz em termos de segurança nacional, considerando a "proteção de vítimas de violação de direitos humanos", assim sendo "pouco eficiente em relação à integração e autonomia dessa população (2018, p. 75).

Além desse conjunto de Leis, Resoluções, medidas e espa-ços de apoio ao imigrante e refugiado que acontecem em caráter oficial, existem também ações de entidades não governamentais, que em parceria com órgãos públicos, privados ou internacionais, colaboram com a recepção e integração da população que migra para o Brasil. Entre eles, estão:

- ADUS: Instituto de Reintegração do Refugiado. Uma instituição sem fins lucrativos que opera desde 2010, oferecendo aulas de português, apoio psicológico, inserção no mercado de trabalho, ações culturais e apoio ao empreendedorismo. ${ }^{56}$

- ACNUR: Agência da ONU para Refugiados. Atua junto aos governos federal, estaduais e municipais espacialmen-

${ }^{57}$ Fonte: https://www.acnur.org/ portugues/acnur-no-brasil/ Acesso em 20 de janeiro de 2019

58 Fonte: http://caritas.org.br/quem-somos-e-historico Acesso em 20 de janeiro de 2019 te em atividades do CONARE, no qual possui uma cadeira com direito a voto. Trata de "proteger os refugiados e promover soluções duradouras para seus problemas" 57

- Cáritas do Brasil ${ }^{58}$ : é um órgão da Conferência Nacional dos Bispos do Brasil (CNBB), que apoia pessoas em situ- 
ação de risco, oferecendo abrigo, cursos de capacitação, apoio psicológico, cursos de português etc.

- Missão Paz ${ }^{59}$ : instituição filantrópica pertencente aos missionários Scalabrinianos que oferece apoio e acolhimento a imigrantes e refugiados na cidade de São Paulo. Possui assento consultivo na Organização das Nações Unidas.

Realiza apoio em quatro eixos: 1) a Casa do Migrante, com capacidade para acolher 110 indivíduos. Nela, recebem acompanhamento de assistentes sociais, apoio psicológico, material de higiene pessoal, alimentação, roupas, aulas de português. 2) O Centro Pastoral e de Mediação dos Migrantes (CPMM), eixo estruturado nos seguintes temas: "documentação e jurídico; trabalho, capacitação e cida-dania; saúde; serviço social; família e comunidade". 3) O Centro de Estudos Migratórios (CEM), um espaço dedicado a estudos e pesquisas, com uma "biblioteca especializada em migração. Publica a revista Travessia, oferece cursos à distância, organiza seminários, assessora momentos de formação". 4) A Igreja Nossa Senhora da Paz, com três paróquias que buscam lidar com a diversidade religiosa da população de imigrantes e refugiados, que "constitui a identidade da Missão Paz, realizando um trabalho que "fortalece a abertura ecumênica e inter-religiosa da igreja, sem proselitismos, acolhendo o imigrante e refugiado como pessoa e respeitando suas escolhas religiosas e tradições culturais."

- Compassiva ${ }^{60}$ : instituição que atua com crianças, adolescentes e refugiados, oferecendo atividades e cursos no campo das artes, esportes e cultura.

- PARR ${ }^{61}$ - Programa de Apoio para a Recolocação dos Refugiados: tem por objetivo "promover a integração de refugiados e solicitantes de refúgio na sociedade brasileira por meio da inclusão laboral", com o intuito de que obtenham a "autossuficiência por meio de seu próprio trabalho".
59 Fonte:

http://www.missaonspaz.org/menu/ quem-somos

Acesso em 20 de janeiro de 2019

60 Fonte: http://compassiva.org.br/ Acesso em 20 de janeiro de 2019

61 Fonte: https://www.refugiadosnobrasil.org/

Acesso em 20 de janeiro de 2019 
- IMDH ${ }^{63}$ - Instituto Migrações e Direitos Humanos: associação filantrópica que realiza "atendimento jurídico e socioassistencial, à acolhida humanitária e à integração social e laboral de migrantes, solicitantes de refúgio, refugiados, refugiadas e apátridas".

- IKMR - I know My Rights (Eu Conheço Meus Direitos) ${ }^{64}$ : organização não governamental que se dedica ao atendimento específico de crianças refugiadas. Realiza atividades culturais e educacionais; trabalha em parceria com o poder público para o fortalecimento de medidas de proteção e bem estar das crianças.

- Migraflix ${ }^{65}$ : organização não governamental que contribui para a integração social e desenvolvimento econômico de refugiados e imigrantes, realizando atividades em torno do compartilhamento de conhecimento dessas pessoas em formato de cursos, workshops e palestras.

Essa infraestrutura de apoio para com o refugiado demonstra o quanto a cidade, enquanto ambiente de acolhimento, se transformou em relação ao tratamento da imigração. Em termos gerais, ela tem buscado se atualizar, seja pelas ações do poder público, seja pelas da sociedade civil, para lidar com as novas conformações dos fluxos de imigrantes e o que delas emergem como questões a serem resolvidas.

https://www.migrante.org.br/ Acesso em 20 de janeiro de 2019

63 Fonte: http://www.ikmr.org.br/quem-somos/ Acesso em 20 de janeiro de 2019

${ }^{64}$ Fonte: http://www.ikmr.org.br/quem-somos/ Acesso em 20 de janeiro de 2019

65 Fonte:

https://www.migraflix.com.br/quem-somos Acesso em 20 de janeiro de 2019 sui uma abrangência significativa em relação ao apoio que imigrantes recebiam no passado. De lá para cá um conjunto de instrumentos legais foram criados, tanto em nível nacional, quanto internacional. Em paralelo, órgãos não governamentais, como instituições sem fins lucrativos sem e com cunho religioso foram criadas, o que se constata é que cada vez mais se fortalecem os meios de viabilização de apoio e controle sobre os direitos do cidadão em situação de imigrante ou refugiado. 
Nas palavras do padre Paolo Parise23, diretor da Missão Paz que, segundo ele, já chegou a abrigar imigrantes de mais de 90 nacionalidades, a questão da imigração não se re-solve somente com o que se tem até hoje, porque
"do ponto de vista de documentação, São
Pau-lo dá uma oportunidade. É relativa- mente fácil conseguir uma documentação, o problema é o restante: a inserção na so- ciedade, arrumar emprego, aí sim que co- meçam os problemas" $(4.03)^{66}$

Problemas relacionados a um ambiente que de um ponto de vista sistêmico, tem buscado estruturar suas condições de fronteira em relação aos que chegam, porém, em relação as suas operações de integração, os trata como imprevistos em diversas circunstâncias, e o resultado disso se evidencia em situações como do sírio Jamal ${ }^{67}$ que, operado de um câncer no Líbano, teve dificuldades para continuar seu tratamento em São Paulo por não falar o português. Em sua primeira consulta, perdeu o agendamento por não ter um acompanhante que falasse português e quando retor-nou do posto de saúde, trouxe um bilhete que dizia "Obri-gatoriamente vir com um acompanhante que fale a língua portuguesa!”. Essa é uma das situações que explicita a falta de estrutura pública para lidar com a complexidade da diversidade de questões posta pelo refúgio.

Narrativas como a de Jamal, em relação a falta de apoio de entidades públicas, despertam sentimentos de solidariedade e ações de mobilidade social e assim, emergem grupos de apoio formados por pessoas que, de algum modo, entram em contato com a crise pessoal ou familiar por eles vividas. Como o grupo de brasileiros ${ }^{68}$ que, por meio de uma vaquinha online, conseguiu arrecadar fundos necessários para ajudar o refugiado sírio, Adnan Alkha-led a trazer sua esposa, Bassema, e seus três filhos, Moham-med, Diana, Sidra e Aisar da Síria. O valor arrecadado via-bilizou a compra de passagens e a documentação.

\footnotetext{
66 Documentário Globo News

67 de set de 2015

https://www.youtube.com/watch?v=VTBOBNVYrEO

Acesso em 18 de junho de 2018

${ }^{68}$ Fonte:

https://www.uol/noticias/especiais/ refugiado-sirio-reencontra-a-familia. htm\#tematico-6? cmpid=copiaecola Acesso em 20 de janeiro de 2019
} 


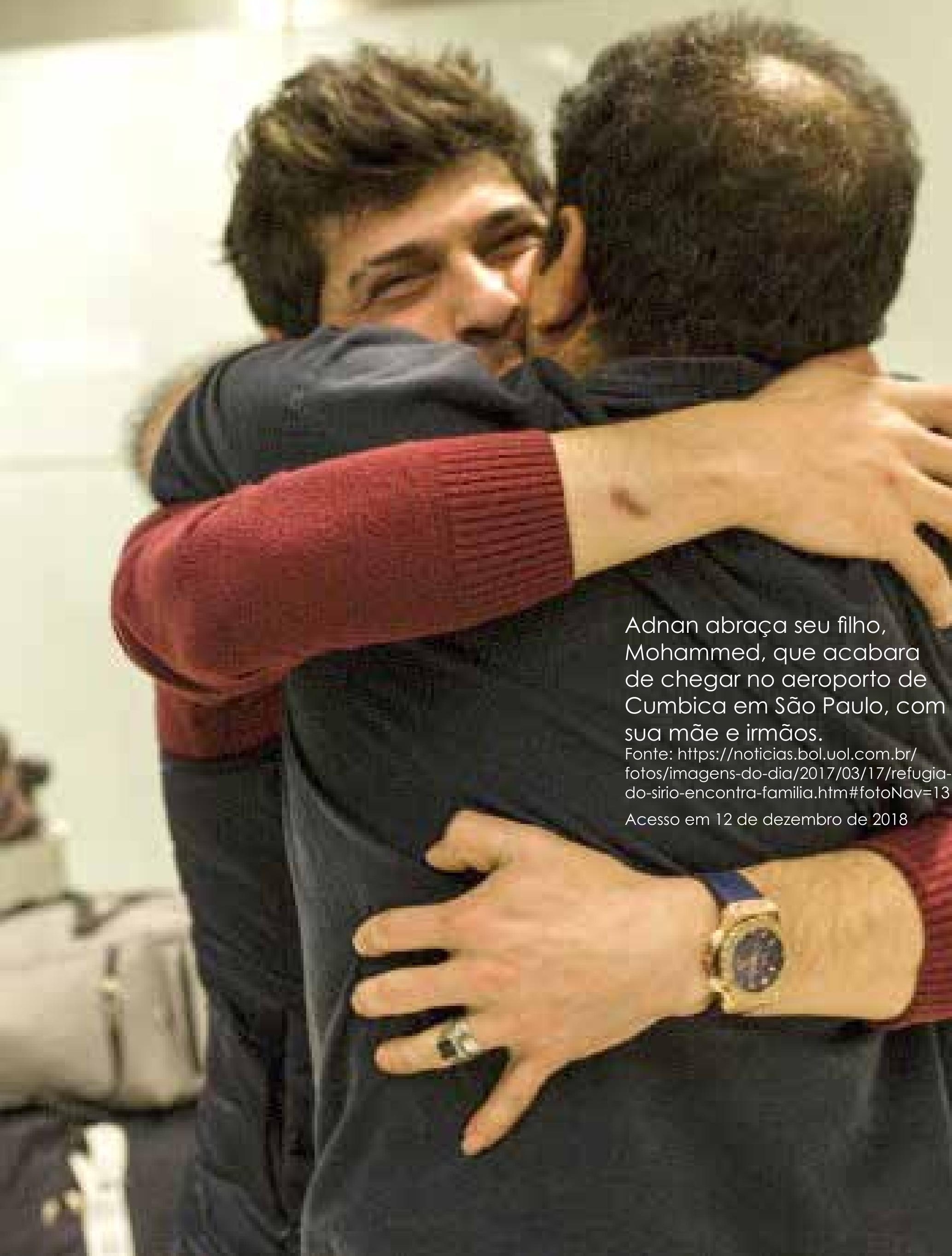





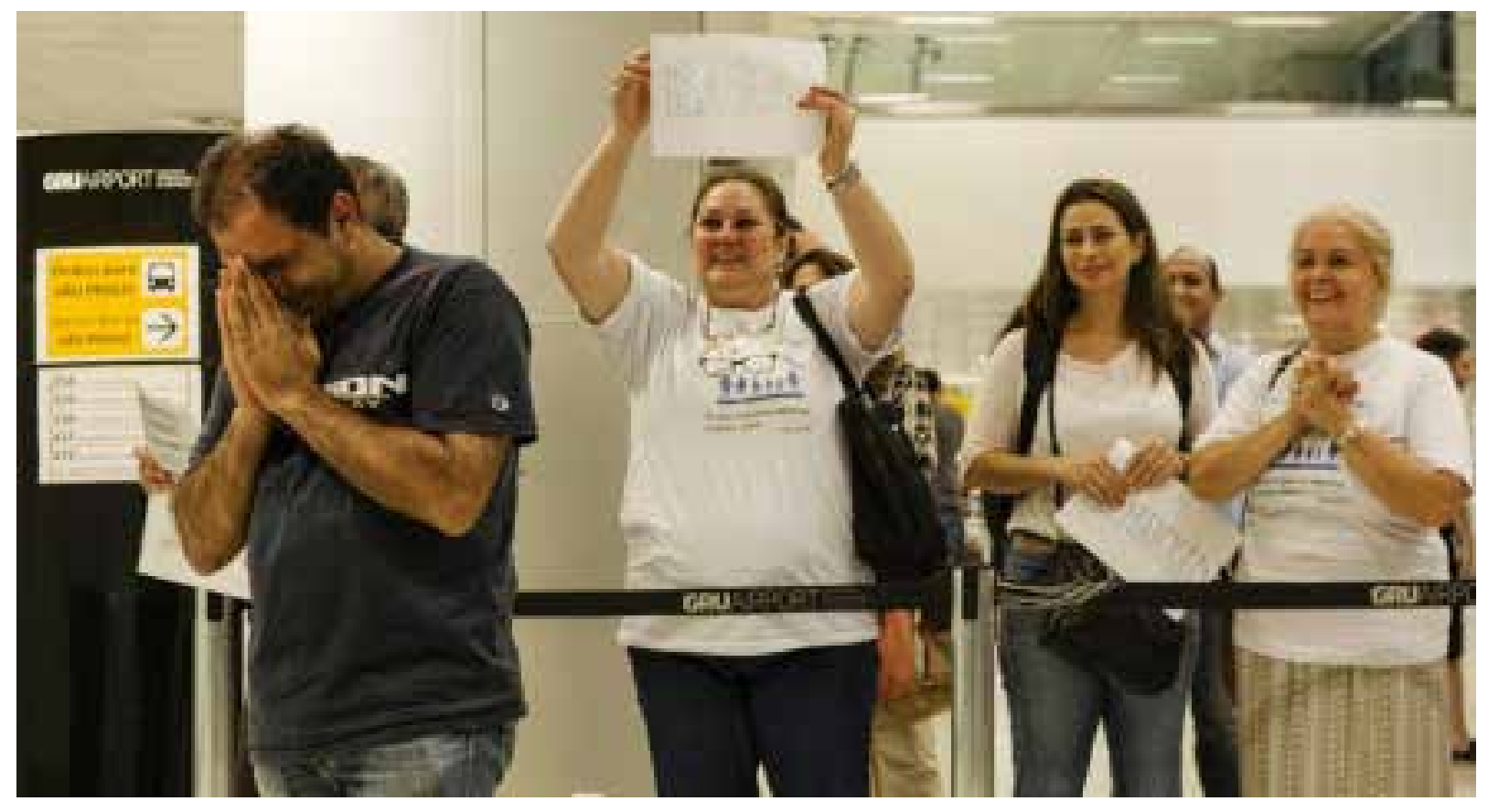

Imagens 1 e 2 https://www.uol/noticias/especiais/ refugiado-sirio-reencontra-a-familia. htm\#tematico-6? cmpid=copiaecola Acesso em 20 de janeiro de 2019
Histórias como a de Adnan acontecem sob vários tipos de contextos, como apoio com acomodação, com a obtenção de trabalho, estudo, aprendizado da língua portuguesa, com a mediação em processos legais etc. Essas ações marcam não somente a vida dos que recebem o apoio como também daqueles que colaboram, como expressaram as pessoas que ajudaram Adnan,

"Desde o início nos colocamos no lugar deles, nos sensibilizando pela maneira cruel com que a guerra separou a família. Ver o abraço do filho mais velho no pai e posteriormente toda a familia, ficou marcado profundamente em nossa memória."

O reencontro familiar aconteceu depois de 20 meses de separação. Um período de convívio com a saudade, a insegurança, o medo e muita luta para ter a família junta novamente.

Esses sentimentos compõem uma parte significativa do ambiente em que vivem alguns dos refugiados em São Paulo. Muitos chegam sozinhos em busca de reconstruir a vida minimamente e economizar, ao máximo, o dinheiro necessário para trazer seus familiares. 
Por motivações e objetivos comuns, o apoio surge também de grupos que têm relação étnica, cultural e religiosa com os sírios, como as comunidades árabes e entidades religiosas.

Após quase 100 anos da primeira imigração Síria na cidade de São Paulo, um grupo dos que imigraram primeiramente se organizam em um clube que leva o nome de uma cidade da Síria, o Club Homs, para elaborar estra-

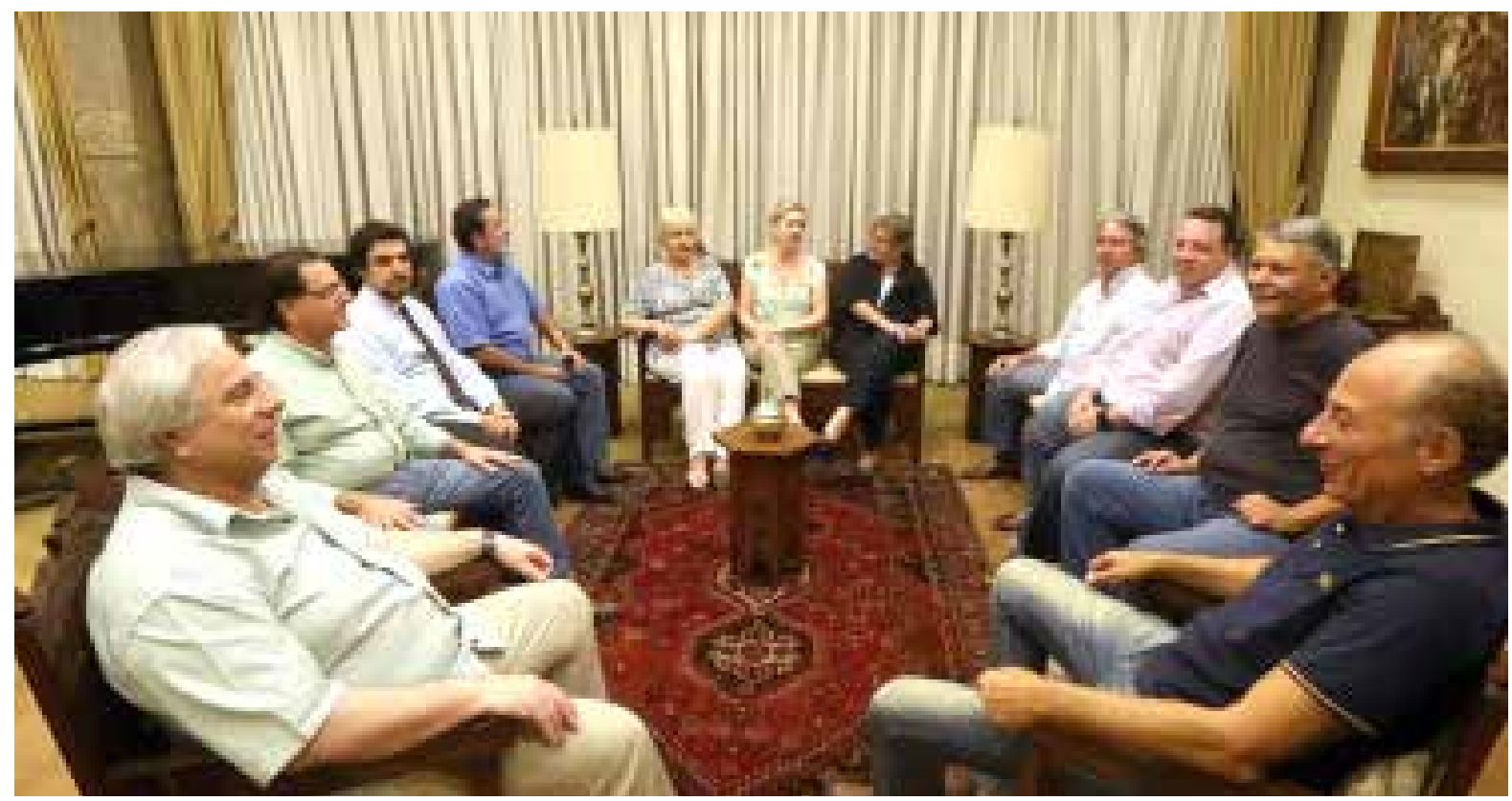

tégias de auxílio aos compatriotas que chegam. Entre as colaborações, estão o ensino da língua portuguesa e auxílio na busca por trabalho.

Segundo $3^{\circ}$ relatório do CONARE 2017 sobre o refúgio no Brasil, São Paulo concentra a segunda maior população de refugiados reconhecidos. Entre os motivos de atração estão, ter a maior comunidade sírio-libanesa do país, ter o maior PIB do Brasil, ser conhecida como uma das principais capitais do mundo, possuir uma das melhores infraestruturas de apoio social (educação, saúde, trabalho), ser uma cidade cosmopolita, ser percebida como um ambiente que favorece a conquista da autonomia econômica, ser a principal porta de entrada no país e ter uma rede de apoio ao refugiado.

Imagem

https://sao-paulo.estadao.com br/noticias/geral,95-anos-depois--colonia-siria-planeja-rede-solidaria, 1766518

Acesso em 21 de janeiro de 2019 


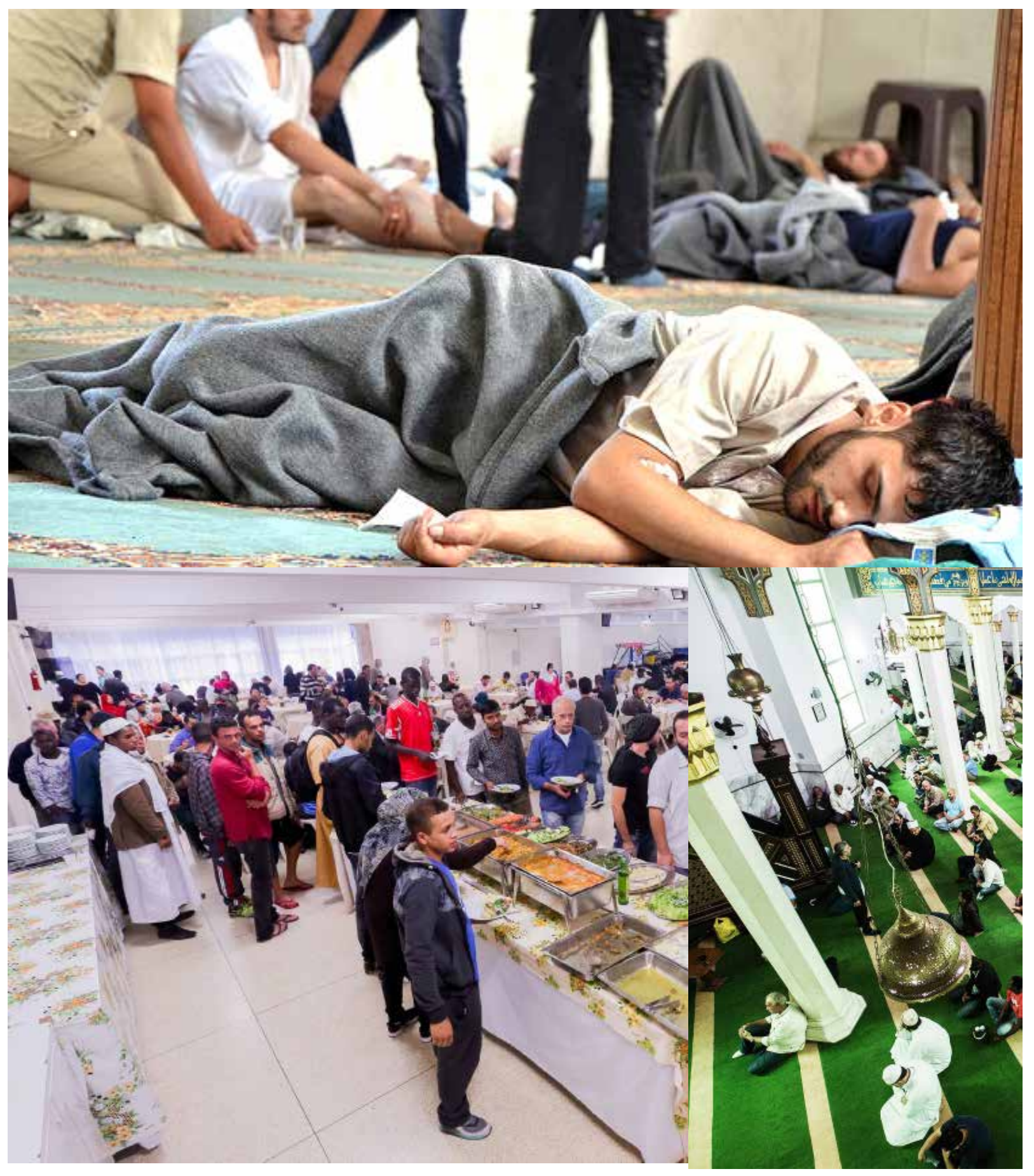

Ahmed, sírio que buscou abrigo na mesquisa de Grarulhos.
Refugiados participam de almoço de confraternização preparado na Mesquita Brasil, na região Central da cidade de São Paulo, às sextas-feiras

https://veja.abril.com.br/brasil/ recomeco-a-vida-dos-refugiados-sirios-em-sao-paulo/
A Mesquita Brasil é um templo islâmico localizado no bairro do Cambuci, bairro central da cidade de São Paulo. Construída em 1929 pela Sociedade Beneficente Muçulmana de São Paulo, é a mais antiga mesquita de todo o Brasil.[1]

https://pt.wikipedia.org/wiki/Mesquita_Brasil 


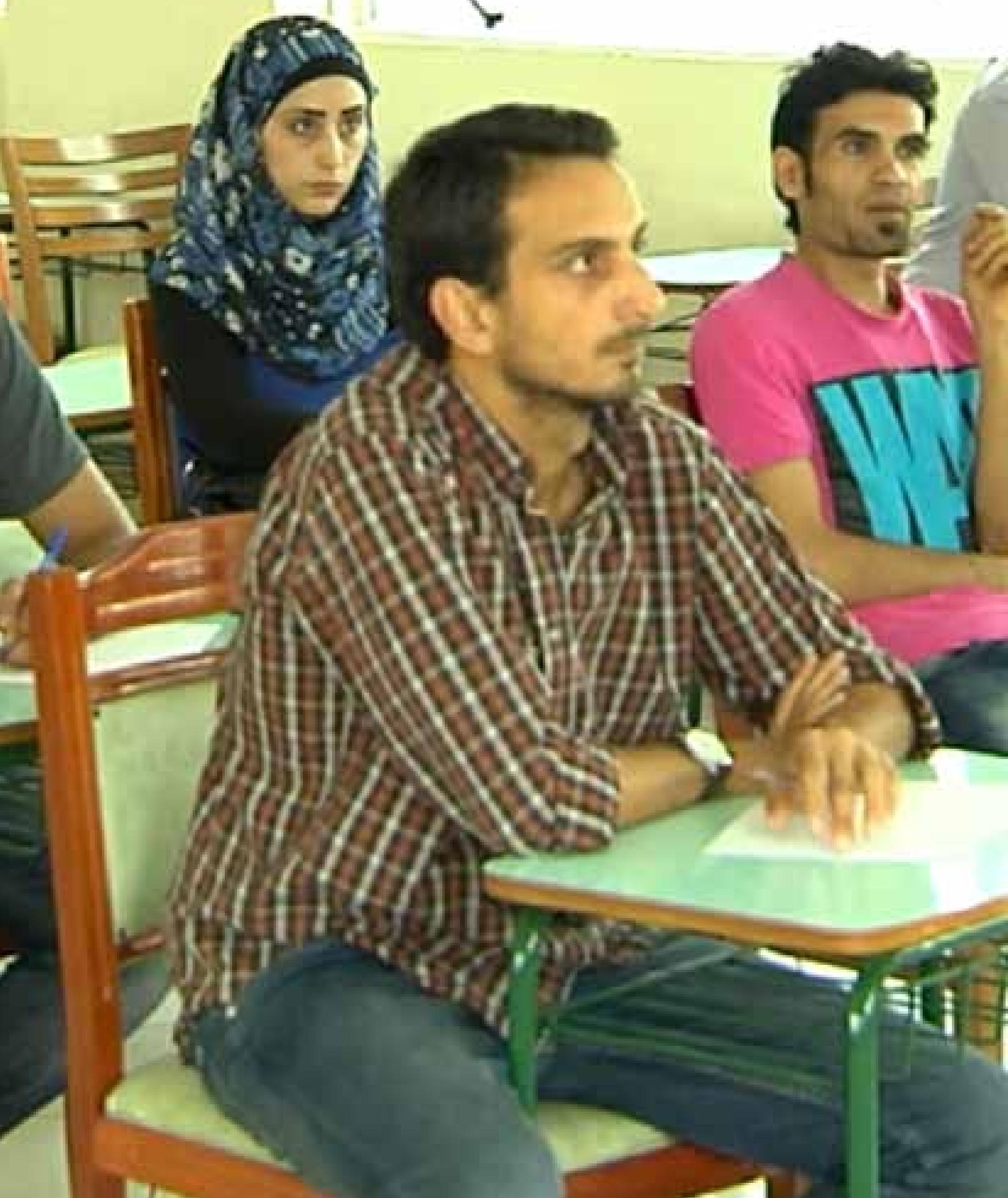


O relatório apresenta ainda, que a solicitação de sírios por refúgio ainda se mantem se retraindo diante de novas crises ao redor do mundo, como a da Venezuela, Cuba, Haiti, e Angola.

\section{Solicitações de Reconhecimento da Condição de Refugiado por Estado}

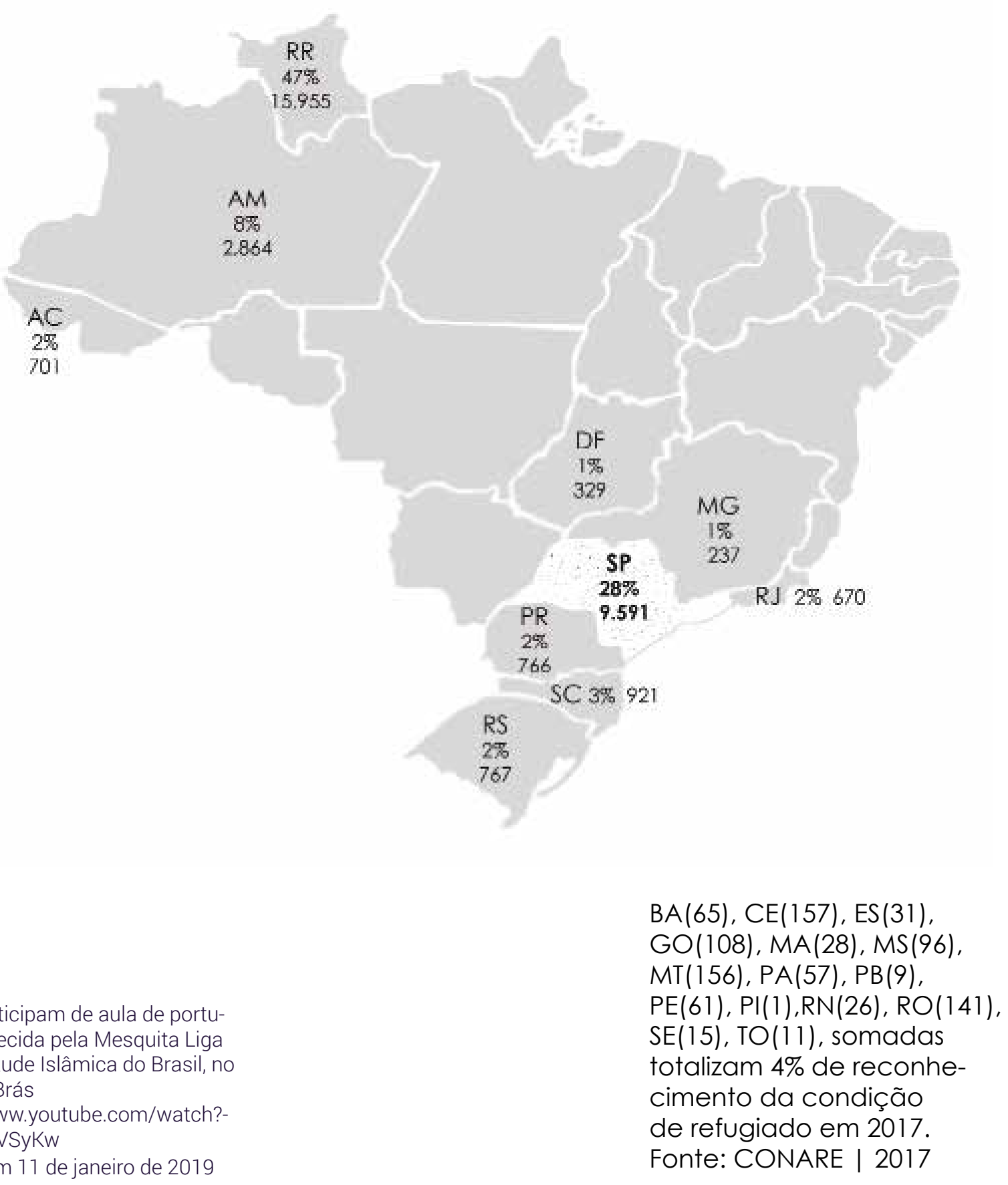

Sírios participam de aula de português oferecida pela Mesquita Liga da Juventude Islâmica do Brasil, no barro do Brás

https://www.youtube.com/watch?$\mathrm{v}=30 \mathrm{ydtc} V S y K w$

Acesso em 11 de janeiro de 2019
$\mathrm{BA}(65), \mathrm{CE}(157), \mathrm{ES}(31)$ $\mathrm{GO}(108), M A(28), M S(96)$ $M T(156), P A(57), P B(9)$, $\mathrm{PE}(61), \mathrm{PI}(1), \mathrm{RN}(26), \mathrm{RO}(141)$, SE(15), TO(11), somadas totalizam $4 \%$ de reconhecimento da condição Fonte: CONARE | 2017 


\section{Dados sobre Refúgio no Brasil}

Fonte: CONARE | 2017

Solicitações de Reconhecimento

da Condição de Refugiado

Total 33.866

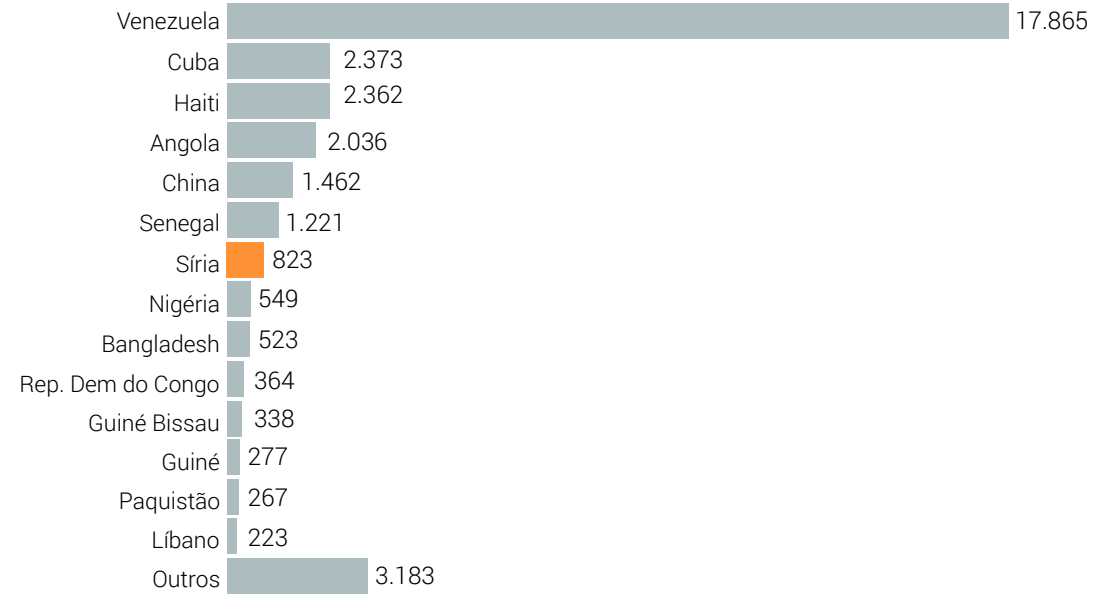

Reconhecimento de

refugiados por país

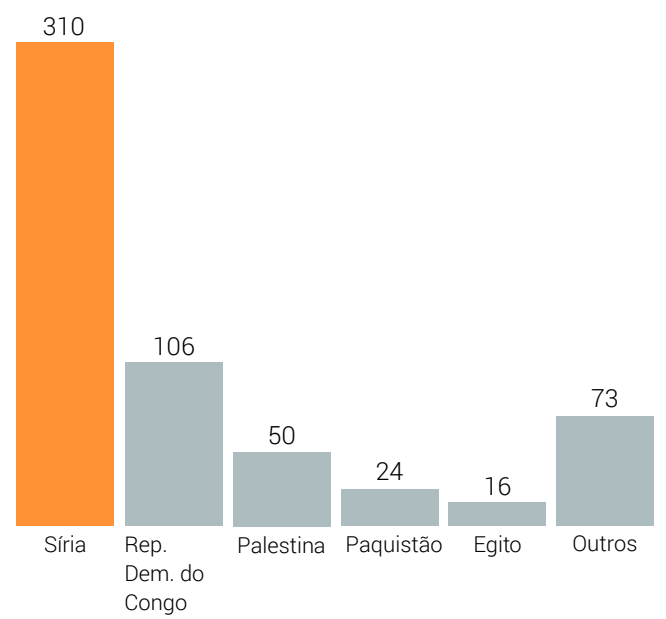

https://www.acnur.org/portugues/wp-content/uploads/2018/04/refugio-em-numeros_1104.pdf

Acesso em 20 de janeiro de 2019 
Elegibilidade das solicitações

de refúgio - Brasil, 2010-2016

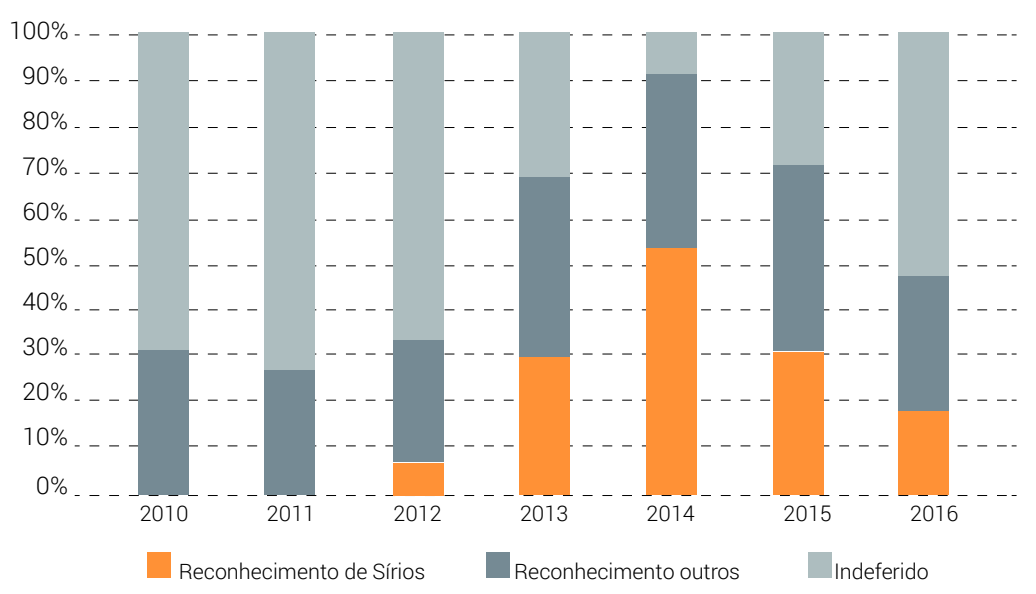

Por Gênero
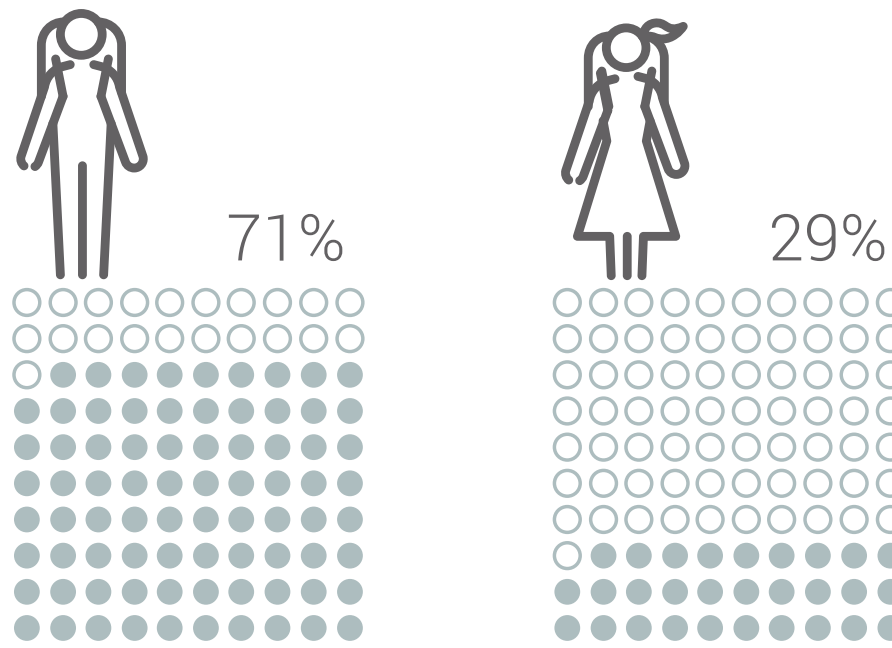

0000000000

0000000000

O०00000000

0000000000

0000000000

0000000000

○०००००००००

000000000

0000000000

0000000000

Por faixa etária

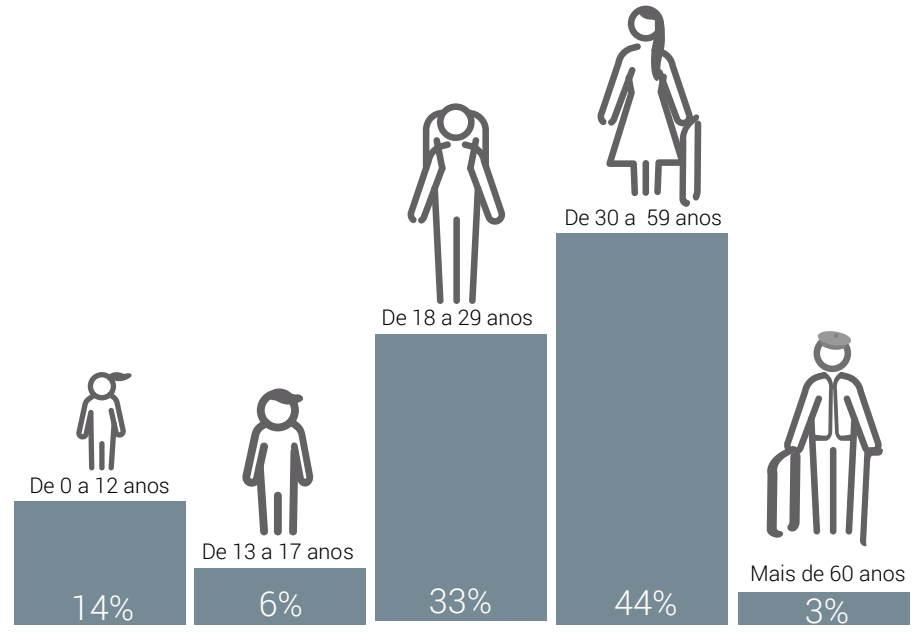




\section{4 \\ O PERFIL DO NOVO IMIGRANTE SÍRIO}

Como já exposto, o perfil do imigrante sírio difere de seus antecessores primeiro pela clareza da necessidade de sair, pelo tipo de acolhida que encontram no Brasil, por uma viagem rápida em comparação aos primeiros imigrantes, pelo status do seu visto - dentro da categoria humanitário e depois substituído pela categoria de refugiado - , o que o coloca em condições de obter a documentação para viver no Brasil de uma forma relativamente rápida. Não há uma caracterização desse novo fluxo por gênero, idade ou classe social. Está tudo misturado, disperso e junto ao mesmo tempo. Nele, há crianças, adultos, famílias, indivíduos, homens e mulheres que chegaram sozinhos ou acompanhados, pertencentes a classe baixa, média, média alta etc.

Segundo a ACNUR ${ }^{69}$, os refugiados "devem ter ao menos os mesmos direitos e a mesma assistência básica recebida por qualquer outro estrangeiro que resida regularmente no país de acolhida", considerando entre esses direitos, os "civis básicos (como liberdade de pensamento e deslocamento, direito a propriedade e não sujeição à tortura e a tratamentos degradantes) e direitos econômicos e sociais", os quais contemplam acesso à "assistência médica, direito ao trabalho e educação". Os refugiados "têm também obrigações, entre elas, o cumprimento das leis e o respeito aos costumes do país onde se encontram." (ACNUR 2018, pg. 7) $69_{\text {https://www.acnur.org/portugues/ }}$ wp-content/uploads/2018/04/refugio-em-numeros_1104.pdf Acesso em 20 de janeiro de 2019 


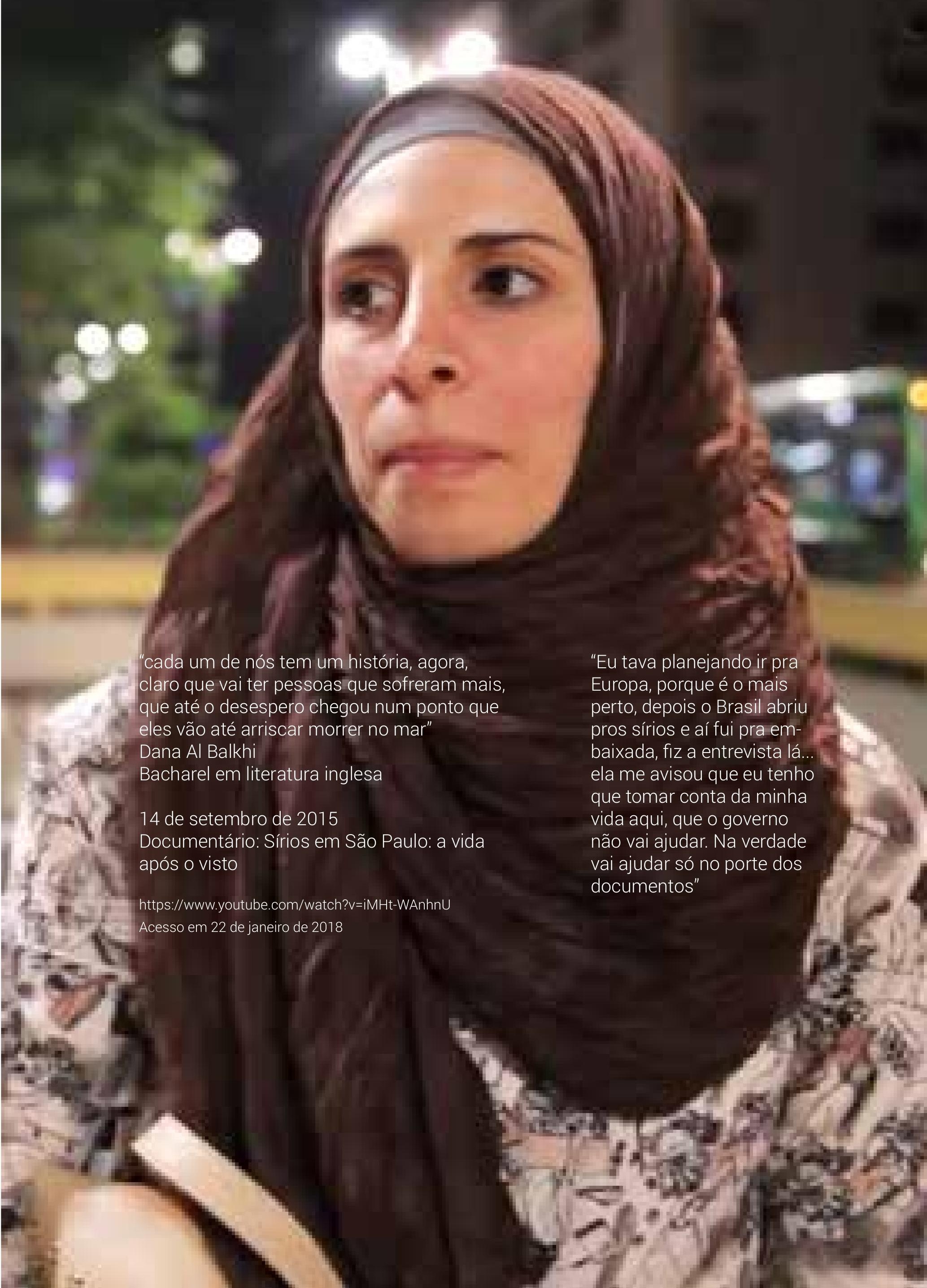




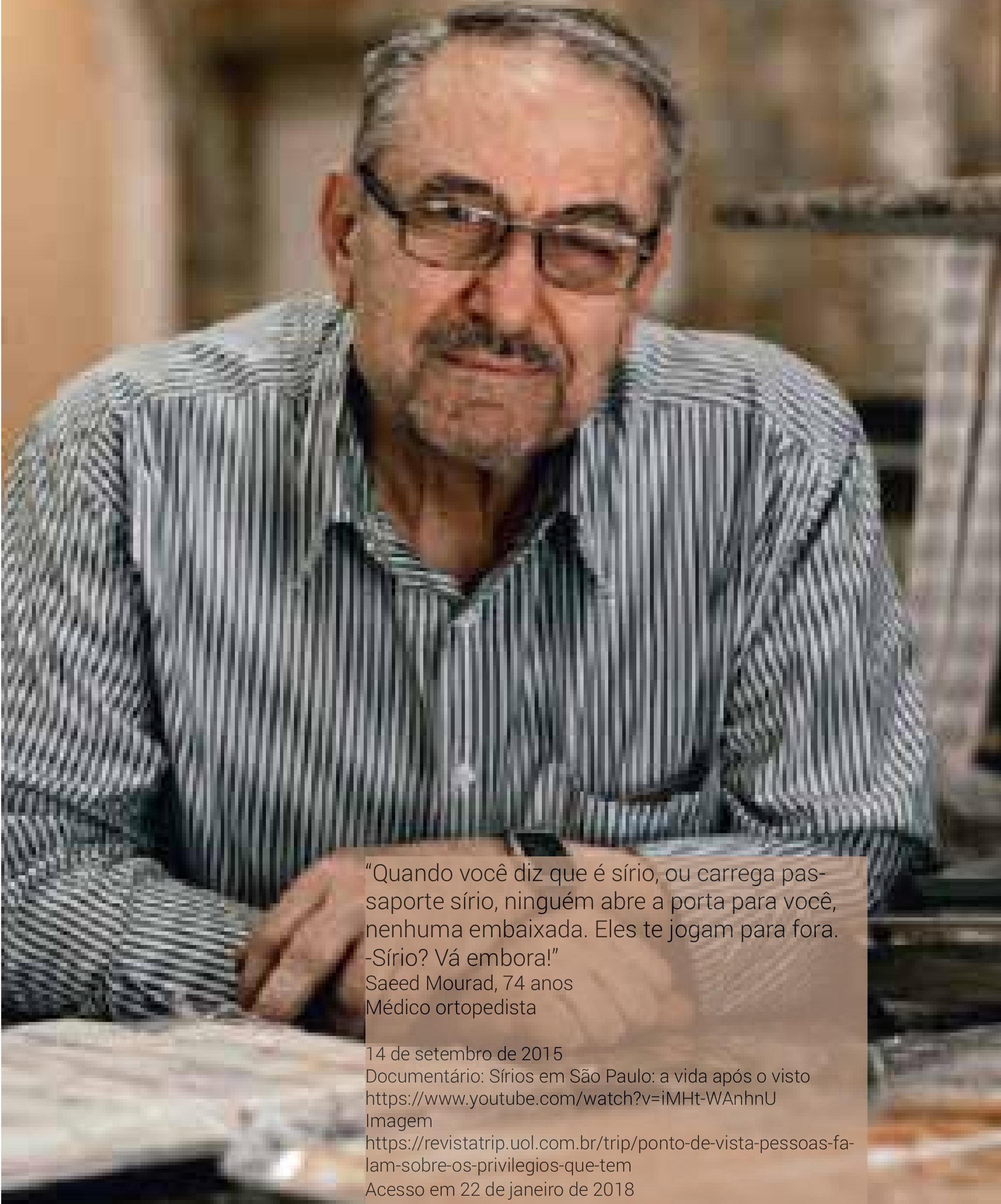



No mesmo relatório é possível obter dados que informam sobre o perfil do refugiado sírio, que também se difere dos que o antecederam, por serem mais heterogêneos em relação a gênero, idade e algumas vezes por estarem em grupo familiar.

A diversidade de perfis de sírios que chega ao Brasil revela o quanto o ambiente necessita ser complexo para lidar com suas demandas. O país, ao abrir suas fronteiras, inevitavelmente verá surgir a necessidade de troca, de interação de modo que o todo se reorganize diante da chegada do novo. Entre sistema e ambiente há uma importante diferença a ser considerada, a de que o segundo sempre será mais complexo do que o primeiro, uma vez que estabelece relação com múltiplos sistemas possuindo, em decorrência disto, muito mais informação e capacidade de processamento. Sem esses atributos, um ambiente que acolhe sistemas complexos entra em colapso, por não conseguir realizar o seu papel, de modo a possibilitar condições favoráveis para que os seus sistemas se mantenham em equilíbrio.

Ao contrário do ambiente, o sistema, neste caso o imigrante sírio na cidade de São Paulo "não tem capacidade de apresentar uma variedade suficiente para responder, ponto por ponto, a imensa possibilidade de estímulos". Luhmann afirma que um sistema deve desenvolver "uma disposição especial para a complexidade, no sentido de ignorar, rechaçar, criar indiferenças, enclausurar-se em si mesmo" (1995, p.179). No que se refere a essa relação, existe a expressão "redução de complexidade"70, que ocorre tanto na relação do sistema com o ambiente, quanto em relação a ele mesmo.
70 Segundo Luhmann, a expressão Redução de Complexidade surge pela primeira vez no livro Study of Thinking (1956) do psicólogo estadunidense Jerome Bruner.(2010, pg 179) 
71 Fonte: http://repositorio.unicamp. br/bitstream/REPOSIP/332529/1/ Quinaglia_MariliaCalegari_D.pdf Acesso em 09 de outubro de 2018
Segundo pesquisa ${ }^{71}$ demográfica realizada pela socióloga e antropóloga Marília Calegari Quinaglia, do Núcleo de Estudos de População (NEPO), da Universidade de Campinas, o perfil de sírios que chega à cidade de São Paulo apresenta caraterísticas que ora se aproximam dos que os antecederema ora se distanciam.

Eles chegam, assim como primeiros migrantes, de modo financeiramente autônomo. Conseguem custear suas

\section{Onde ficou ao chegar na cidade}

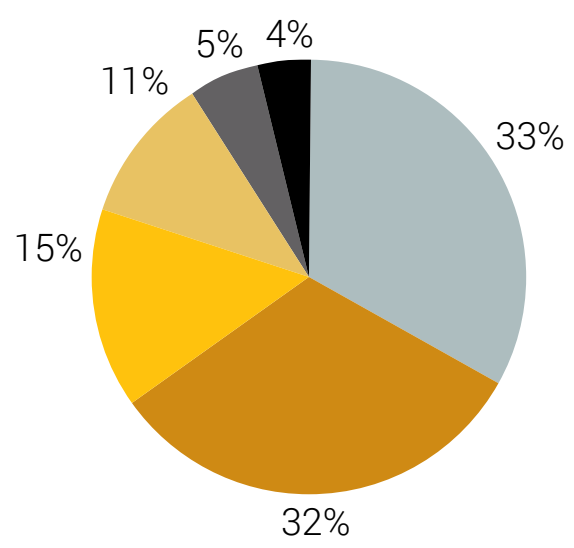

Morou em hotel ao chegar

Chegou com casa já alugada

Morou com amigos

Morou com parentes

Morou em Mesquistas

Em outro lugar

Fonte: Calegari, 2018 | Observatório das Migrações em São Paulo.Questionário "Refugiados Sírios em São Paulo", 2015

passagens e possuem condições para se manter durante algum tempo, como demonstra o gráfico abaixo.

A soma da terceira, quarta e quinta fatia do gráfico, a partir dos que moram com amigos em sentido horário, chega a 31\% e apresenta um valor significativo em termos de ambiente de acolhimento. Este valor demonstra que, embora o ambiente seja novo, algumas conexões não. Isto, de algum modo, abre maiores possibilidade de integração, quando são auxiliados a conhecer seus direitos e deveres como refugiados no Brasil. 
Outro dado revelador é que em idade adulta, eles são, na maioria, portadores de diploma de graduação, havendo também aqueles com ensino técnico e pós-graduação, uma característica muito distinta daqueles do primeiro fluxo migratório.

Dois fatores dificultam e, em muitos casos, impedem essa integração pelo reconhecimento profissional. O primeiro, é que muitos tiveram seus documentos de comprovação destruídos nas explosões de suas casas, o segundo, que lhes falta o domínio da língua portuguesa. Outra razão que dificulta o processo de reconhecimento são os tramites dentro do Brasil. Segundo Quinaglia, de 76 sírios com ensino superior, "apenas 5 conseguiram fazer a re-

\section{Grau de formação}

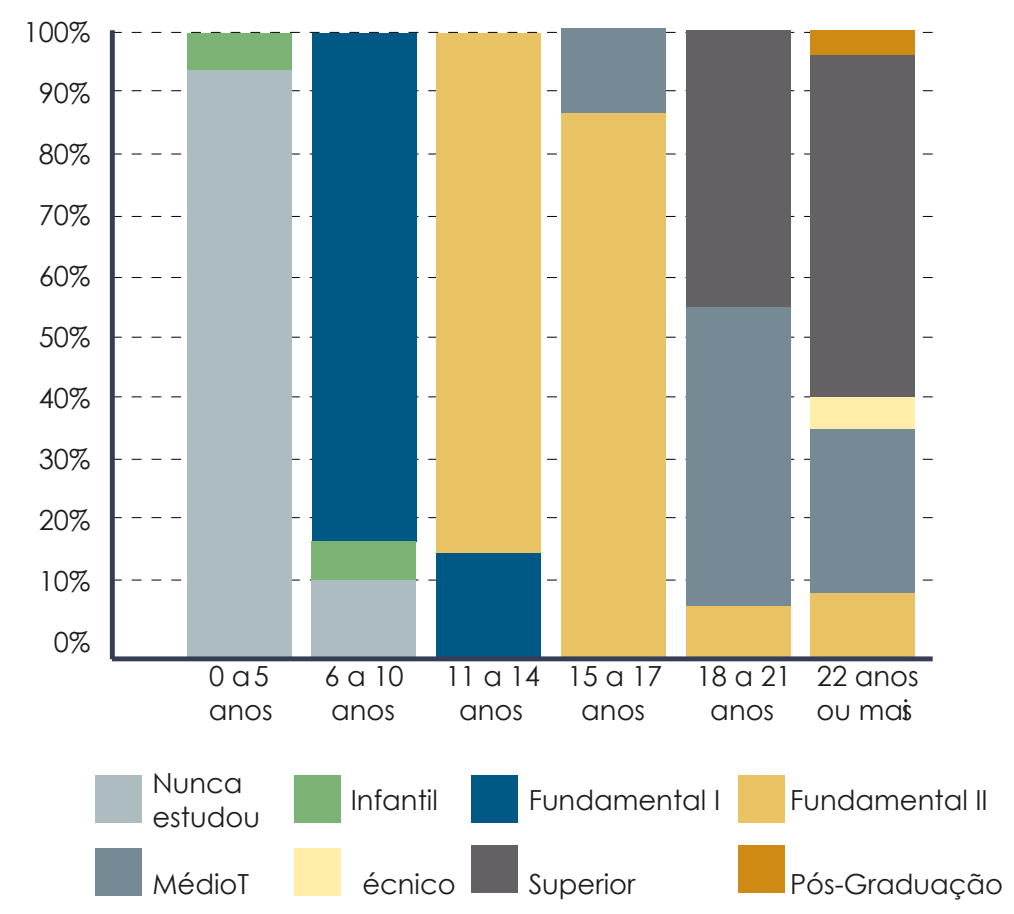

Fonte: Calegari, 2018 | Observatório das Migrações em São Paulo.Questionário "Refugiados Sírios em São Paulo", 2015 
Fonte: Calegari, 2018 | Observatório das Migrações em São Paulo.Questionário "Refugiados Sírios em São Paulo", 2015

validação por meio de diplomas e certificados" (2018, pg. 127), sendo que a maioria não buscou validar e 11 tiveram seus pedidos negados por falta de documentação. De acordo com a pesquisadora, 6 não responderam a essa questão.

Uma das barreiras em relação ao processo burocrático, foi rompida em março de 2018, por meio de Lei sancionada pelo governo do estado de São Paulo, pela qual refugiados ficariam isentos do pagamento de taxa de revalidação de diplomas de graduação, pós-graduação, mestrado e doutorado pelas universidades públicas de São Paulo(USP e UNICAMP). Valores que para muitos dos refugiados eram um impeditivo para a realização do processo, uma vez que chegavam a custar mais de $\$ 540$.

HOMENS MULHERES

$\begin{array}{lll}\text { Empregado } & 60 & 6 \\ \text { Autônomo } & 3 & 0 \\ \text { Empregador } & 2 & 0 \\ \text { Dono de negócio familiar } & 1 & 0 \\ \text { Trabalhador em negócio familiar sem remuneração } & 0 & 1 \\ \text { Autônomo da economia informal } & 1 & 0 \\ \text { Desempregado } & 16 & 3 \\ \text { Estudante } & 2 & 3 \\ \text { Não pretende trabalhar } & 5 & 39\end{array}$

TOTAL

O quadro sobre a insercão dessas pessoas no mercado de trabalho é um extrato representativo de uma população maior, que se repete em alguns relatórios que tratam desses aspectos. Vale ressaltar que a ocupação como "empregado", não está associada a um emprego correspondente à formação acadêmica. Essa ocupação é facilmente localizada em lojas de assistência técnica de equipamentos 
eletrônicos e em restaurantes de comida Árabe. Os que empreendem em negócios próprios atuam, na maioria, com o preparo de comida Árabe. Um desses exemplos é a farmacêutica Salsabil Matouk, retratada na parede de um prédio próximo ao elevado Costa e Silva, no centro de São Paulo, como representante do processo de acolhimento de refugiados que vivem na cidade de São Paulo.

Imagens

https://nacoesunidas.org/eu-nunca-imaginei-viver-brasil/
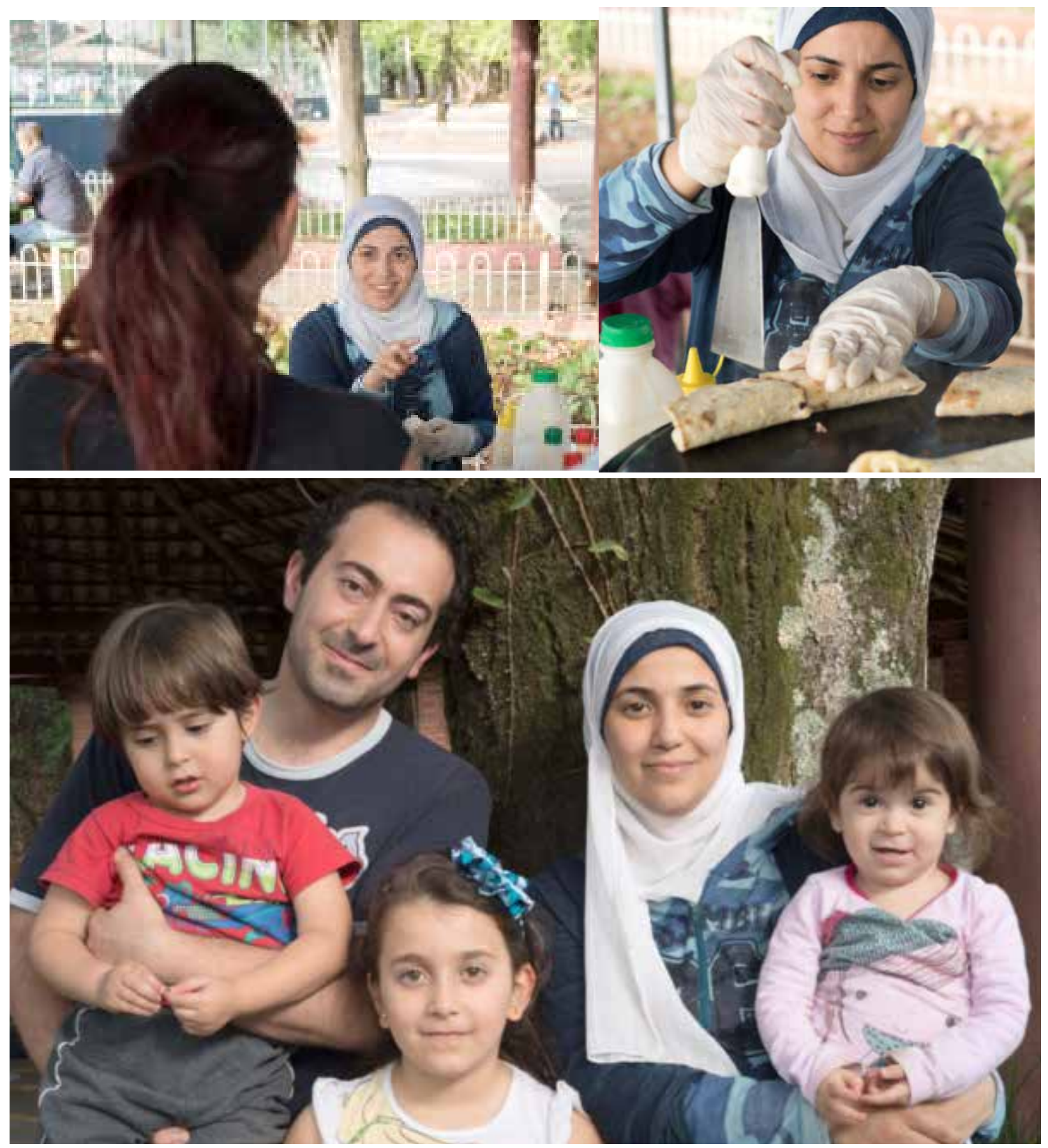

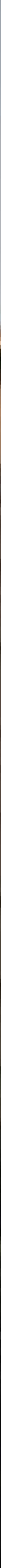


\section{IMIGRAÇÃO É REDE}

Um dos padrões que se manifesta pelo fenômeno da imigração é do rede, que é um dos desafios postos pela compreensão de fenômenos complexos em relação à captura das relações entre seus elementos que, de modo geral, moldam sua organização como um todo.

É possível definir rede como organizações que se conformam a partir de conexões baseadas em relações. Esse padrão sistêmico é considerado uma das principais chaves para se compreender, pela perspectiva da interconexão, o comportamento de vários dos sistemas que fazem parte do nosso mundo. Em termos de representação, redes são abstrações que, por um processo de redução de informações dispensáveis, chegam ao essencial, permitindo de modo abrangente a visualização de relações existentes em uma estrutura.

O matemático suíço Leonhard Paul Euler (1736) foi considerado um dos percussores da ideia de rede ao criar um desenho sintético do espaço geográfico da cidade de Königsberg. A motivação para essa representação veio do "desafio das sete pontes de Königsberg" cujo objetivo era construir um percurso que incluísse passar apenar uma vez por cada uma das pontes da cidade. Do desenho, foram eliminados todos os detalhes insignificantes para o estudo, como a distância entre uma ponte e outra e seus tamanhos. Com isso, ele obteve uma representação abstrata que continha apenas linhas e pontos, posteriormente denominada de grafo ${ }^{71}$.
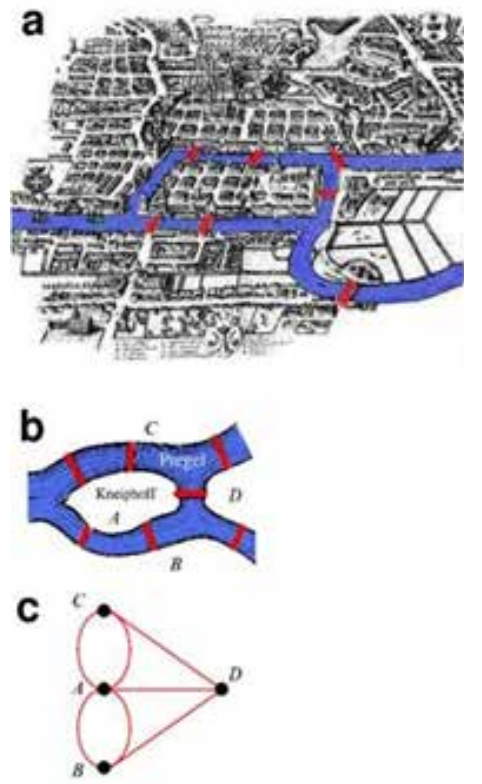

71 Grafo é uma representação abstrata baseada em linhas e pontos que representam as conexões existentes na dinâmica do conjunto representado. (texto próprio) 
A teoria das redes não possui apenas um marco, mas vários, de diferentes áreas do conhecimento, como a matemática, a física, a biologia, a economia, a comunicação e a computação, todas com um objetivo comum, a busca por um modo de descrever, representar e modelar o modo como se organizam as coisas quando postas em relação com outras em um ambiente de interconexão, de forma a se obter uma visão sistêmica do todo em termos de relação.

É comum que coisas sejam identificadas e descritas por suas propriedades físicas, funcionais e pelo que proporcionam, no entanto, análises como essas satisfazem apenas a necessidade de compreensão de um sistema relativamente isolado que não alcança a contextualização do sistema dentro de uma estrutura de interações com outros, em um ambiente de conectividade. Um aspecto da estrutura que promove a conformação da dinâmica do todo.

Essas relações se cruzam e se sobrepõem em círculos sociais com vínculos de influências distintos. Esta perspectiva de rede é da ordem do complexo, ao ter o pressuposto de que indivíduos estão interligados em redes interdependentes, onde cada um influi sobre o outro e, consequentemente, criam novas conformações sociais a partir de valores que nutrem e mantém a rede.

Um dos estudos mais importantes sobre redes pela perspectiva do domínio social foi realizado pelo engenheiro Paul Baran, que demonstrou, em memorando publicado em 1963, que redes possuem estruturas e que estas são determinadas pelo modo como as conexões se estabelecem. Ele as sistematizou dentro da dimensão social em três principais topologias, a saber: distribuída, centralizada e descentralizada. Apresentou, a partir da estrutura de cada uma, as variedades de influências que emergem do modo como se organizam seus elementos e suas conexões. 
Segundo Baran, as conexões das redes centralizadas convergem para um único nó, recaindo sobre este o maior grau de influência sobre o todo. Este aspecto de centralidade a torna ágil e eficiente em termos de controle, porém, frágil em caso de um eventual dano no elemento de controle, enquanto que nas redes descentralizadas, a influência se dispersa por centros variados, o que faz com que tenha maior capacidade para se auto-organizar caso sofra alguma ruptura.

As redes distribuídas, por sua vez, se caracterizam por uma rede de maior complexidade. Sua manutenção depende de um equilíbrio dinâmico, que está sob o domínio do todo e não de um centro. A característica principal de redes distribuídas está na ausência de centralidade e em um padrão de relações mais simétrico, com quantidades similares de conexões entre os nós, aspecto que traz para esse tipo de rede a horizontalidade de influências.

Como visto anteriormente, a rede de apoio ao refugiado sírio se transformou ao longo do tempo e, de uma rede com característica do tipo centralizada do primeiro fluxo, tendo como elemento principal o setor público, evoluiu para a de múltiplos centros, do tipo descentralizada, nos quais se localizam representantes do governo e de instituições não governamentais.

O padrão de rede descentralizada possui maior complexidade porque o grau de hierarquia não é equilibrado, há distintos níveis de influência entre um centro e outro e isso pode impactar significativamente no fluxo de informações dentro da rede.

Por uma visão de rede, o fenômeno da imigração necessita ser visto por situações pelas quais seus fluxos e desvios tocam. Redes como a de migração são estruturas dinâmicas, que podem se alterar em decorrência de ações de seus elementos, como as da imigração legal e clandestina, que fazem surgir conexões que dão forma a tipologias distintas para o mesmo objetivo: entrar no lugar X. 
Conformações como a do grupo de brasileiros que se solidarizou com a história de Adnan e o ajudou a trazer sua família para o Brasil, por meio de uma campanha online de arrecadação de dinheiro, se caracterizam como redes centralizadas, porque havia um núcleo de concentração do processo de arrecadação. As pessoas sabiam para onde estavam indo suas colaborações; elas tinham um ponto de referência.

A rede que se formou em torno do problema de Adnan foi também uma rede emergente. O grupo surgiu e se estruturou por um conjunto de fatores significativos para todos e, a partir de um certo número de pessoas, se expandiu pela conexão de outras pessoas que também se mobilizaram e passaram a colaborar com um objetivo que se tornou seu.

Para o comerciante sírio Amer Massarani, que vive em São Paulo há 20 anos, criador do Oasis Solidário ${ }^{72}$,

"Se não é a comunidade árabe e o povo brasileiro, os refugiados hoje estariam nas ruas, dormindo nas praças como que a gente vê lá na Europa Oriental, onde estão tratando mal as pessoas." 73

Diagramas das Redes de Paul Baran. Fonte: Baran (1964), p.2.

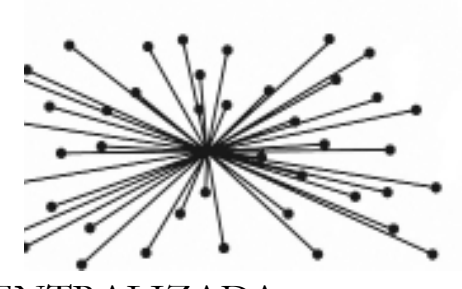

CENTRALIZADA

Pela perspectiva de relação imigrante e governo. Nessa estrutura, há um poder central que estabelece sob quais condições a dinâmica da rede acontece.

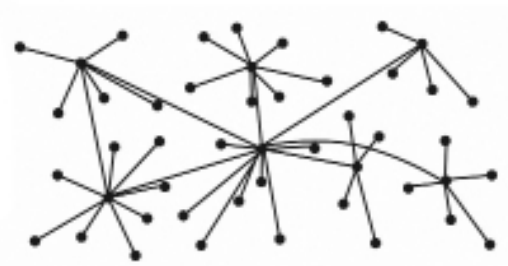

DESCENTRALIZADA

Quando as relações com o imigrante acontecem não por um, mas por vários núcleos de apoio, como ONG's, igrejas, centros de apoio etc.

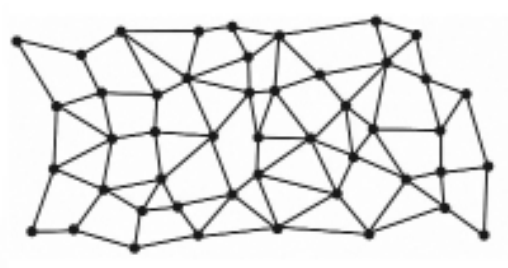

DISTRIBUÍDA

Se caracteriza pelo modo como o imigrante encontra soluções para seus problemas a partir de relações estabelecidas com outros indivíduos. sem que por detrás haja uma representação que se caracterize como dominante. 
mo os conhecer, as dificuldades enfrentadas por refugiados em São Paulo seriam ainda maiores.

O sociólogo Manuel Castells se refere a redes no contexto do social denominando-as como estruturas, dizendo que "são o conceito fundamental da teoria social" pelas quais "todas as outras coisas funcionam" (1999, p. 76). De acordo com ele há no espaço das estruturas sociais, das redes, dois tipos de vínculos, os laços fracos e os fortes. Os laços fracos são úteis ao "fornecimento de informações e na abertura de novas oportunidades a baixo custo". São aqueles estabelecidos com desconhecidos em busca de uma solução para um problema, "num modelo igualitário de interação, no qual as características sociais são menos influentes na estruturação, ou mesmo, no bloqueio da comunicação" (1999, p. 445). Esse tipo de conexão está circunscrita dentro do ambiente de comunicação digital, por ser o um espaço propício para a formação de múltiplas relações, acolhendo e agregando interesses diversos, desde os mais individuais até os de importância para o coletivo, prescindindo de qualquer influência de relações no passado. De modo diferente, os laços fortes são definidos pelas relações mais íntimas e duradouras, que normalmente ocorrem também no mundo concreto ou real.

Basicamente a estrutura de uma rede é composta por três elementos passíveis de serem observáveis, os nós ou vértices, as arestas ou ligações e o grau de conectividade. É a partir desses três elementos que são descritas, analisadas e modeladas.

Através desse modelo simplificado de representação, e do arcabouço conceitual que a teoria das redes disponibiliza, se viabiliza o estudo sobre uma diversidade de redes, como as econômicas, as de logística, as biológicas, psicológicas, políticas etc., que não são apenas conjuntos de partes, mas sim conexões, sobre as quais importa também saber de que modo fluem as trocas e sob qual grau de conectividade acontecem. 
Assim como a teoria de sistemas é uma linguagem formal para se descrever organizações, a teoria das redes é utilizada para descrever de que modo tais organizações se conformam como estruturas de comunicação.

Os abraços de Adnan em sua família foram possíveis porque a sinergia das ações de um grupo de pessoas fez emergir o que ele, sozinho, não poderia. Atividades como essa acontecem sem muita exceção em redes descentralizadas, sem uma coordenação central, apenas com um evento de iniciação e podem crescer, ou simplesmente não evoluir. Esses movimentos dependerão de igrejas, de instâncias públicas e instituições não governamentais que formam a rede de apoio ao refugiado.

Atualmente, com o conceito de redes aplicado ao desenvolvimento de tecnologias de processamento de dados, é possível mapear, em tempo real, o comportamentos de fenômenos de alta complexidade, permitindo a visualização de suas dinâmicas, transformações e projeções, como o de fenômenos meteorológicos. O mesmo acontece com sistemas de trânsito, financeiro e de epidemias, pela visualização das possibilidades de propagação em uma rede de possíveis contágios, por exemplo. Esta é uma nova maneira de observação, que é conduzida por algoritmos que processam quantidades densas de dados, permitindo o acesso a mais

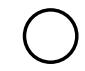

NÓS/VERTICES - representam os elementos de um sistema, como pessoas, objetos, regras e cidades.
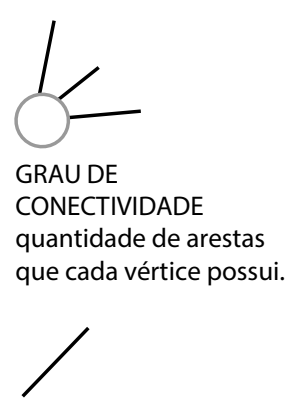

ARESTAS - são as relações estabelecidas entre os nós. 
Uma das questões importantes a respeito de uma rede é o seu grau de conectividade, tanto pela quantidade de conexões de seus elementos, quanto de si mesma em relação a outras redes com as quais estabelece trocas. Aspectos que permitem identificar qualidades como a velocidade com que os resultados iniciais de um evento podem se propagar pela rede e fora dela. $\mathrm{O}$ tamanho da rede e a distância entre um nó e outro - denominado comprimento médio de conexão -, seja ela física ou digital, permite aferir valores de propagação.

À medida em que se avança do paradigma industrial para o da sociedade da informação, a capacidade de conexão e de relação como o outro tem se expandido em vários contextos, o que faz com que se esteja imerso em redes dentro de redes, com estruturas particulares e lógicas de conexão e relação que colocam o desafio de compreendê-las para que nelas, e por elas, seja possível manter o equilíbrio na diversidade de ambientes pelos quais se transita e se migra.
Representação criada a partir das aproximações entre um sistema e outro, relações entre elas e grau 
REDES DE APOIO

\section{AO REFÚGIADO EM}

SÃO PAULO
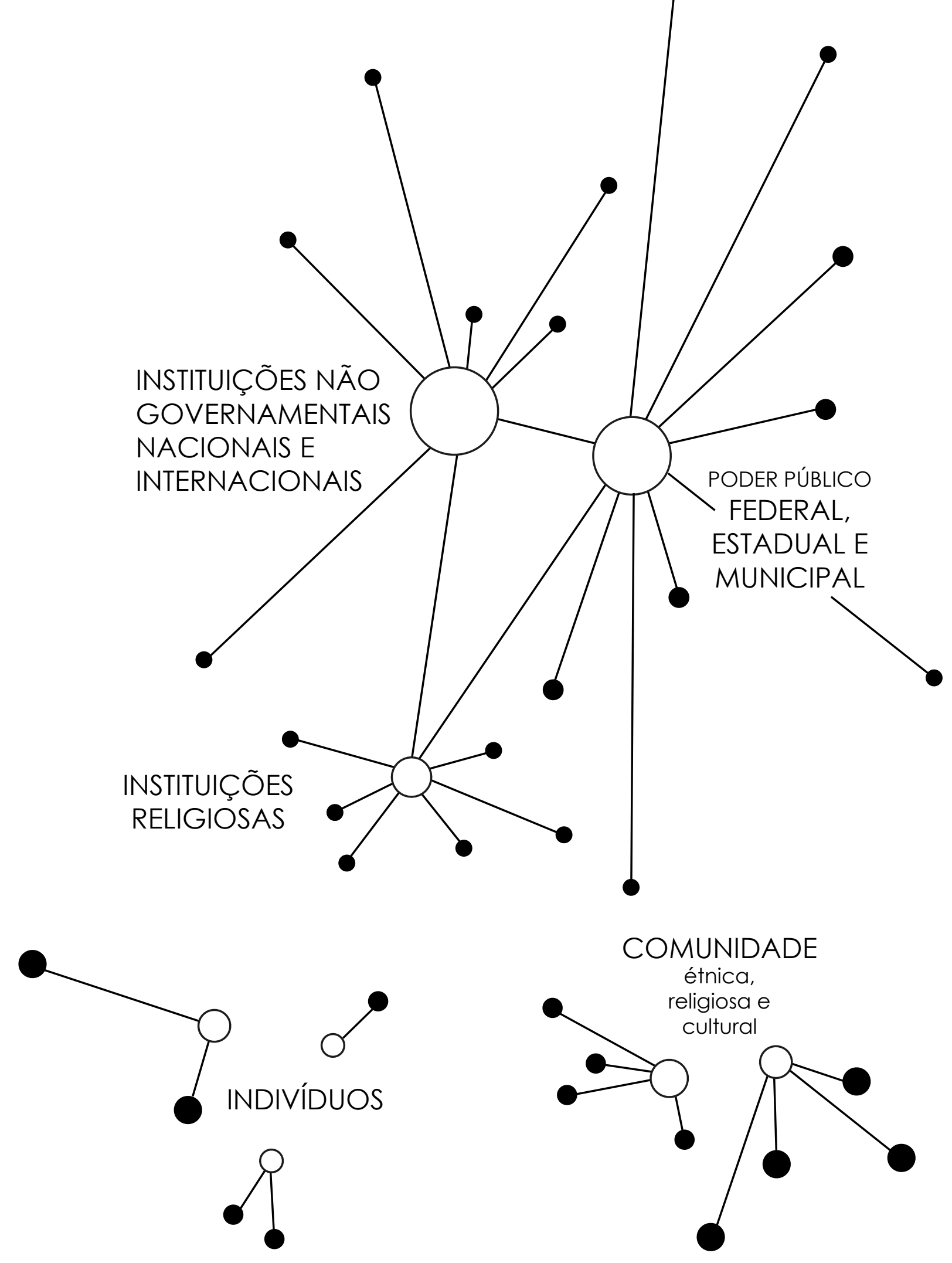



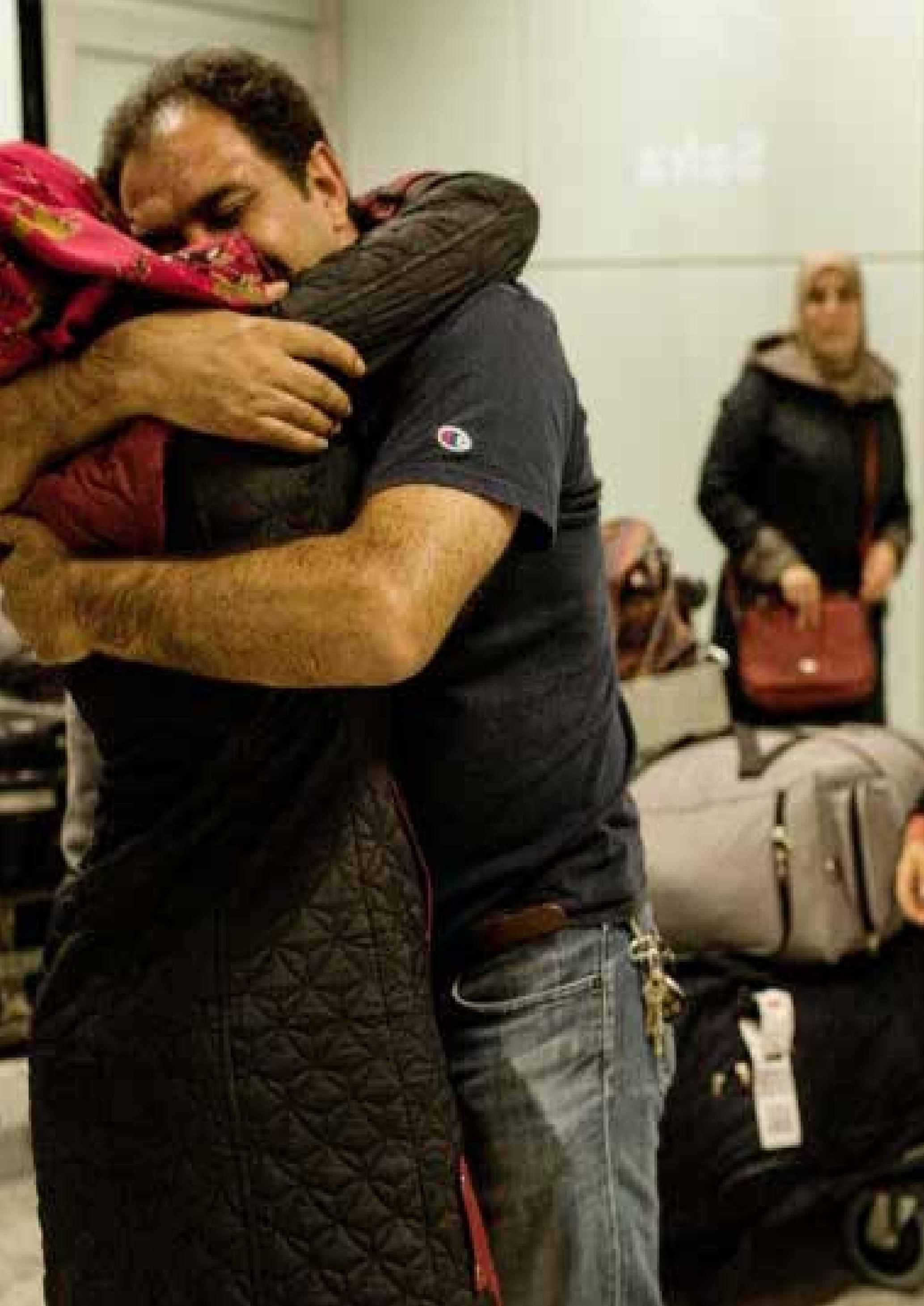


216 FAUUSP TESE DE DOUTORADO MIGRAÇÃO, COMPLEXIDADE E DESIGN 
$\mid$

\section{EMERGÊNCIAS}


218 FAUUSP TESE DE DOUTORADO MIGRAÇÃO, COMPLEXIDADE E DESIGN 

220 FAUUSP TESE DE DOUTORADO MIGRAÇÃO, COMPLEXIDADE E DESIGN 
Ao longo do processo de pesquisa, certezas iniciais cederam à força de um movimento, do qual não se pode esquecer ou desviar: a emergência.

O fenômeno abordado, a imigração de sírios na cidade de São Paulo foi, ao longo do tempo, se expondo como algo de muitas facetas. Das quais surgiam elementos carregados de sentido sobre o que é ser complexo.

Uma situação emblemática ocorreu ao tentar realizar uma entrevista com um sírio que havia conhecido em um Congresso sobre imigração e refúgio. Após várias tentativas e finalmente acertada a conversa, em torno de uma hora antes recebi uma mensagem que dizia: "Vilma, me desculpe, mas precisaremos remarcar nosso encontro, meu primo acabou de morrer na Síria e não posso me encontrar com você hoje".

Esse estado de suspensão e sentimento de apreensão fazem parte do ambiente dos refugiados sírios, com os quais tive contato. A crise reverbera em cada um que teve a sua vida interrompida, de um momento para o outro, pela guerra que destrói o país. Não se trata de um evento somente, mas de vários: perde-se o lar, o trabalho, parentes, amigos, bens e, com isso, emergem situações que se impõem e com as quais não se aprendeu a lidar. Não é comum viver tudo isso ao mesmo tempo e ter que deixar tudo para trás, em busca de um lugar para manter-se vivo.

Dos conceitos discutidos ao longo da tese, um ficou reservado para o final: o de Emergência. Em design aprendemos que nossas atividades se baseiam em pesquisa e desenvolvimento. E que temos um modo de pensar que é relacional, que olha para as coisas e buscar estabelecer conexões. Isso me faz lembrar de Luhmann e de uma de 
suas perguntas: nesse processo, afinal, “quem observa o observador?" (1995). O teórico recorre aos tipos de organização de máquinas cibernéticas, que trabalham por mecanismos de feedback positivo e negativo, para abordar um ponto chave em contextos de pesquisa: enquanto pesquisamos ou, ampliando a questão, enquanto projetamos, sob quais condições o fazemos?

Trabalhar com design pressupõe a capacidade de aprender a planejar, controlar, sistematizar e a programar o que virá a seguir, o dia depois de hoje, o mês e ano que ainda nem chegaram. Ter o domínio do processo. É assim que muitos se referem a esta que é considerada como uma das principais qualidades desse profissional. A minha reflexão a respeito é: em qual caixinha são colocadas as emergências? Como se lida com o que não estava apontado pelo projeto? Como resposta, ouso dizer: não há compartimento no mundo em que caibam as emergências. Não há formulas ou metodologias previamente elaboradas que dêem conta delas.

Nenhum dos refugiados, com os quais tive contato, sabia o que havia acontecido, tão menos, o que se sucederia depois. Com ameaça constante à sua dignidade, desde o momento da partida de seu país de origem até o da adaptação no lugar para onde se dirigem, eles vivem momentos delicados que vão desde um imenso sentimento de perda até a consciência de que nunca mais terão ou serão o que até esse momento haviam construído.

A status de imigrante de guerra ou de refugiado ainda lhes reserva, ao mesmo tempo, a condição de vítima e de indesejável; como uma presença que se impõe e que não deveria estar ali, algo inesperado que exige, por parte dos governos e das populações, um enfrentamento que traz para a superfície sentimentos de solidariedade, mas também de muito ódio. Esse sujeito se torna uma emergência a enfrentar situações emergentes, sobre as quais não sabe 
nada. Um aspecto necessário aos estudos da emergência é o ambiente, uma vez que tudo surge dentro de um espaço de informações, matéria ou energia e todos esses elementos contribuem como barreiras ou favorecimento ao surgimento do novo.

Desde o surgimento da ciência moderna, que nossa compreensão de mundo foi se moldando por uma noção construída a partir de uma percepção científica e matemática. O modelo mental que surgiu dessa visão ainda se faz presente, podendo ser percebido, de algum modo, na maneira como descrevemos as coisas. Nessa descrição ainda há o predomínio de retas, círculos, quadrados e outras formas geométricas, invariavelmente estruturadas como linearidades de causa e efeito. E o mundo, não é bem assim.

No mundo há muito mais desvios e imprevistos do que processos que possam ser controlados. É disto que trata a não linearidade; sobre explicar que - diferentemente de sistemas lineares, sobre os quais podem ser previstos resultados a partir do que se determina em sua entrada, processamento e saída - não há, nos fenômenos complexos, a possibilidade de que ocorram relações diretas entre causa e efeito, porque são indeterminados, o que, de modo reverso, significa que esses fenômenos não podem ser elucidados, completamente, por seus resultados ou por seus processos passados, e tão pouco ser previsto, com precisão, o seu futuro.

Embora o mundo seja composto por diversos sistemas complexos que, invariavelmente, são subsistemas de organizações maiores, não se pode desprezar as contribuições da matemática para o desenvolvimento de modelagens de sistemas o que, em diversas áreas, permite acessar, ainda que de forma aproximada, o comportamento de fenômenos em tempo real e, assim, gerar ou prever possíveis ocorrências. 
A questão posta pela complexidade é a de que, no mundo em que vivemos, mudanças, pequenas ou aparentemente insignificantes, podem modificar completamente a resultante e, boa parte desses resultados, são imprevisíveis, por se colocarem como emergentes.

Assim, sistemas não lineares, como a economia, a sociedade, o corpo humano, os fluxos migratórios etc., não são governados por princípios de sobreposição ou de sequencialidade e, por este motivo, não podem ser observados através dos mesmos instrumentos que constroem compreensões a partir desse tipo de organização, que busca apreender o futuro como determinado por entradas e saídas, independentes e isoladas, facilmente antevistas e controláveis, portanto. A não linearidade é uma qualidade inerente a todos os sistemas complexos.

Problemas como o da imigração Síria, que numa primeira visada, não fazem parte dos endereçados ao campo do design, possuem comportamentos que disponibilizam um conjunto de elementos e estruturas que nos permitem compreender a performance de um sistema complexo.

Numa perspectiva ampliada, no entanto, de um design estratégico que se direciona para questões que vão além do seu classicismo projetual - relacionado à produção de objetos, comunicação visual ou interações digitais - pode-se afirmar, sem nenhum temor, que este encontra na complexidade seu lugar de ação.

A imigração Síria na cidade de São Paulo não é um caso para o departamento de assistência social, para a área da saúde, educação, segurança, desenvolvimento social etc. É para todos, certamente, porém, em conjunto, de fato. E nesse sentido, a visão de projeto do design, que é de relação, pode contribuir para a organização do ambiente através de intervenções que considerem as partes em função do todo, ao longo do tempo em que a situação aconteça. 
E que esse todo se volte também para as suas partes, num olhar que, além de reflexivo, seja também expansivo, na medida em que identifica e valoriza o ambiente no qual o sistema está inserido.

Projetos e metodologias tradicionais são insuficientes para promover respostas eficazes para problemas capciosos. Se a guerra na Síria se desdobrou em algo que interessa ao mundo, não serão medidas imediatistas, embora sejam necessárias para reequilibrar situações críticas, que a resolverá eficazmente, uma vez que carrega dimensões sociais, psíquicas, emocionais, econômicas e afetivas, para citar apenas as mais evidentes.

As emergências e a possibilidade de entendê-las, como parte de processos sobre o qual o homem não tem controle e das quais é impossível se livrar, torna o design uma ferramenta fundamental não só para o entendimento da complexidade do mundo - alinhado, obviamente, às teorias do conhecimento que tratam de se afastar das linearidades - mas também como um campo de ação sobre esses fenômenos.

O entendimento do que é emergente, deve se pautar não só pela compreensão de algo que surge como problema, mas também em relação ao que aparece como oportunidade para o resgate da consciência de que somos seres que vivemos num mesmo lugar: o planeta terra. Desse modo, é possível concluir que estamos todos dentro de um ecossistema de pensamento, produção, intervenção e ligação entre saberes, vidas e possibilidades. 
226 FAUUSP TESE DE DOUTORADO MIGRAÇĀO, COMPLEXIDADE E DESIGN 


\section{REFERÊNCIAS}

AGAMBEN, Giorgio. O que é o contemporâneo e outros ensaios. Chapecó, SC.: Argos, 2009.

AGIER, Michel. Migrações, descentramento e cosmopolitismo: uma antropologia das fronteiras. São Paulo: Edufal e Unesp, 2015.

ALMEIDA, Elimar P., PENA-VEGA, Alfredo (org.). O pensar complexo: Edgar Morin e a crise da modernidade. Rio de Janeiro: Garamond, 1999.

ARAÚJO, Shadia Husseini de. O "islã" como força política na "primavera árabe": uma perspectiva da teoria do discurso. História: Questões \& Debates. Curitiba, n. 58, jan/jun. 2013. p. 39 - 62,

BAENINGER R., BRAGA A. M. da C., TEIXEIRA E., (org.) Migrações: implicações passadas, presentes e futuras Marília: Oficina Universitária; São Paulo: Cultura Acadêmica: 2012.

BAR-YAM, Yanner. Dynamics of complex systems. Massachusetts: Library of Congress, 1997.

Making things work: solving complex problems in a complex world. Cambridge, MA: Knowledge Press. 2005.

BASSANEZI, M. S. B. Imigrações Internacionais no Brasil: um panorama histórico. In: PATARRA, Neide Lopes (org.) Emigração e Imigração Internacional no Brasil Contemporâneo. Campinas: FNUAP, 1995. p. 1-38.

BERRY, Thomas e SWIMME, Brian. The Universe Story:From the Primordial Flaring Forth to the Ecozoic Era. New York: Harper Collins Publishers, 1992. 
BERTALANFFY, Ludwig von. Teoria geral dos sistemas:fundamentos, desenvolvimento e aplicações. Petrópolis, RJ:

Vozes, 1968.

CARDOSO, Rafael. Design para um mundo complexo.

São Paulo: Cosac Naify, 2012

CAPRA, Fritjof. O ponto de mutação: a ciência, a sociedade e a cultura emergente. São Paulo, Cultrix, 2006.

A Visão sistêmica da vida: uma concepção unificada e suas implicações filosóficas, politicas, sociais e econômicas. São Paulo: Cultrix, 2014.

CASTELLS, Manuel. Fim de milênio. São Paulo: Paz e Terra, 1999.

Manuel. A sociedade em rede: a era da Informação, Economia, Sociedade e Cultura. Rio de Janeiro: Paz e Terra, 2008.

CRARY, Jonathan. 24/7: capitalismo tardio e os fins do sono. São Paulo. Cosac Naify, 2014.

DESCARTES, René. O discurso do método. São Paulo: LPM, 1637.

GUATARRI, Félix. Caosmose: um novo paradigma estético. São Paulo: Editora. 34, 1992.

IBGE. Brasil: 500 anos de povoamento / IBGE, Centro de Documentação e Disseminação de Informações. Rio de Janeiro: IBGE, 2007.

JOHNSON, Steven. Emergência: a dinâmica da rede em formigas, cérebros, cidades e softwares. Rio de Janeiro: Zahar, 2003.

JONES, Peter. H. Systemic design principles for complex social systems. In: JONES, Peter e METCALF, Gary S. (orgs.). Social Systems and Design. Springer Verlag 2014. cap. 4, p. 91-128. 
KERCKHOVE, Derrick de. A pele da cultura. Lisboa: Relógio D’Água Editores, 1997.

KOIFMAN, Fábio. Imigrante ideal: o ministério da justiça e a entrada de estrangeiros no Brasil (1941-1945). Rio de Janeiro: Civilização Brasileira, 2012.

LÉNA, Philippe; NASCIMENTO, Elimar Pinheiro do (orgs.). Enfrentando os limites do crescimento: sustentabilidade, decrescimento e prosperidade. Rio de Janeiro: Garamond, 2012.

LUHMANN, Niklas. Introdução a teoria dos sistemas. Rio de Janeiro: Vozes, 1995.

MALDONADO, Tomás. Cultura, sociedade e técnica. SãoPaulo: Blucher, 2012.

MALDONATO, Mauro. Na hora da decisão: somos sujeitos conscientes ou máquinas biológicas? São Paulo: Edições Sesc, 2017.

MATURANA, Humberto; VARELA, Francisco J. A árvore do conhecimento: as bases biológicas da compreensão humana. São Paulo: Pala Athenas, 2001.

. "Autopoiesis: the organization of the living", originalmente publicado sob o título De Maquinas y Seres Vivos. Editorial Universitaria, Santiago, Chile, 1972; reimpresso in Maturana e Varela (1974).

MELHEN, Adas. Panorama geográfico do Brasil: contradições, impasses e desafios socioespaciais. São Paulo: Moderna, 2004.

MENDES, Candido (org.). Representação e complexidade. Rio de Janeiro: Garamond, 2003.

MORAES, Dijon de. Metaprojeto: o design do design. SãoPaulo: Blucher, 2010. 
MORAIS, José L. B de; SANTORO, Emílio; TEIXIERA, Anderson V. Direitos dos migrantes. São Leopoldo, RS:

Unisinos, 2015.

MORGAN, Gareth. Imagens da organização. São Paulo: Atlas, 2002.

MORIN, Edgar. Ciência com consciência. Rio de Janeiro: Bertrand Brasil, 1996.

Introdução ao pensamento complexo. Lisboa:

Instituto Piaget, 2008.

NEVES, Fabrício Monteiro; RODRIGUES, Léo Peixoto 2012. Niklas Luhmann: a sociedade como sistema. Porto Alegre: Edipucrs, 2012.

PRIGOGINE, Ilya. O fim das certezas. São Paulo: Unesp, 1997.

As leis do caos. São Paulo: Unesp, 2002.

QUINAGLIA, Marília Calegari. Com lenço e com documento: condições de vida da população refugiada síria em São Paulo. 2018. Tese (Doutorado). Instituto de Filosofia e Ciências Humanas da Universidade Estadual de Campinas (UNICAMP), Campinas: São Paulo, 2018.

SAFADY, Wadih. Cenas e cenários dos caminhos de minha vida: depoimento e contribuição para a história da imigração dos povos árabes para o Brasil. Volume 1. Belo Horizonte: Edit. Sta. Maria, 1966.

LENA, Philippe; NASCIMENTO, Elimar Pinheiro (orgs.). Enfrentando os limites do crescimento, sustentabilidade, decrescimento e prosperidade. Rio de Janeiro: Garamond, 2012.

SASSEN, Saskia. Sociologia da Globalização. Porto Alegre: Artmed, 2010. 
TAGER, Djénane Kareh. Edgar Morin: meu caminho. Rio de Janeiro: Bertrand Brasil, 2010.

TRUZZI, Oswaldo. De mascates a doutores: sírios e libaneses em São Paulo. São Paulo: Ed. Sumaré, 1992.

. O lugar certo na época certa: sírios e libaneses no Brasil e nos Estados Unidos - um enfoque comparativo. Estudos Históricos. Rio de Janeiro, na 27, 2001. p. 110-140.

VASCONCELLOS, Maria José Esteves de. Pensamento sistêmico: o novo paradigma da ciência. Campinas, SP: Papirus, 2013.

VIRILIO, Paul. Espaço crítico. Rio de Janeiro: Editora 34, 1993.

WAHL, Daniel Christian. Design de Culturas Regenerativas. Rio de Janeiro: Bambual: 2019.

WIENER, Norbert. Cibernética e sociedade: o uso humano de seres humanos. São Paulo: Cultrix, 1968.

ZAHREDDINE, Danny. A crise na Síria (2011-2013): uma análise multifatorial. Revista Conjuntura Austral. São Paulo, vol. 4, no. 20, Out. Nov. 2013. p. 6 - 22.

ZIZEK, Slavo. Acontecimento: uma viagem filosófica através de um conceito. Rio de Janeiro: Zahar, 2017.

\section{BASES ELETRÔNICAS}

BARAN, Paul. On Distributed Communications: Introduction to Distributed Communications Networks. Memorandum RM-3420-PR, ago. 1964. Disponível em <:https:/ / www.rand.org/content/dam/rand/pubs/research_memoranda/2006/RM3420.pdf >. Acesso em: 22 fev. 2016. 
BOL. Disponível em < https://noticias.bol.uol.com.br/ultimas- noticias/educacao/2017/12/14/refugiado-sirio-consegue-bolsa-em-faculdade-de-sp-com-rede-solidaria.htm $>$ Acesso em 10/12/2018.

Cartilha ACNUR. Disponível em https://www.acnur.org/ fileadmin/Documentos/portugues/Publicacoes/2018/ Cartilha_Protegendo_Refugiados_No_Brasil_2018.pdf?file $=$ fileadmin $/$ Documentos $/$ portugues $/$ Publicacoes $/ 2018 /$ Cartilha_Protegendo_Refugiados_No_Brasil_2018. Acesso em 13/03/2018.

Chegada de Italianos de navio. Disponível em < https:// www.pesquisaitaliana.com.br/viagem-de-navio-entre-a-italiae-o-brasil/>. Acesso em 12/12/2017.

EULER, Leonhard Paul. As pontes de Königsberg. Disponível em < https://www.mat.uc.pt/ alma/escolas/pontes/>. Acesso em 25/07/2018.

Histórico de Sírios no Brasil. Disponível em < http://museudaimigracao.org.br/sobre-os-poucos-registros-para-sirios-e-libaneses-na-hospedaria-dos-imigrantes/>. Acesso em 10/06/2018.

IBGE. Disponível em http://www.brasil.gov.br/noticias/ cidadania-e-inclusao/2018/08/populacao-brasileira-ultrapassa-208-milhoes-de-pessoas-revela-ibge $>$. Acesso em 24 de março de 2019.

IRWIN, Terry. Wicked Problems and Design: A Digram. 2012. Disponível em < https:/ /www.academia. edu/6086328/Wicked_Problems_and_Design_A_Diagram. $>$ 2012. Acesso em 10/09/2007.

Mesquita Brasil. Disponível em < https://www.youtube. $\mathrm{com} /$ watch? $=V_{s} C G t 3 \_$zJus $>$. Acesso em 12/04/2017.

MORIN, Edgar. Fronteiras do Pensamento, 2013. Disponível em < https://www.youtube.com/watch?v=VmFB9Vcac1U>. Acesso em 01/09/ 2018. 
MORTEAN. Disponível em < https://www.folhadelondrina.com.br/mundo/entenda-as-causas-do-conflito-nasiria-974583.html >. Acesso em 01/01/2019.

Nações Unidas. Disponível em < https://nacoesunidas.org/ travessia-do-mediterraneo-e-a-mais-mortal-para-migrantesdiz-relatorio-da-onu/ > . Acesso em 23 de dezembro de 2018

RAMOS, Jair de Souza. O poder de domar o fraco: construção de autoridade pública e técnicas de poder tutelar nas políticas de imigração e colonização do serviço de povoamento do solo nacional, do Brasil. Horizontes Antropológicos. Porto Alegre, ano 9, p. 15- 47, julho de 2003. Disponível em < http://www.scielo.br/scielo.php?script=sci_arttext\&pid=S0104-71832003000100002 >. Acesso em 15 setembro 2017.

Revista FAPESP. Disponível em < http://revistapesquisa.fapesp.br/2012/11/12/os-indesejaveis/>. Acesso em 12/05/2018.

WEBBER, M. Melvin e RITTEL, Horst W.J. Dilemmas in a general theory of planning. Disponível em $<$ http://urbanpolicy.net/wp-content/uploads/2012/11/Rittel+Webber_1973_PolicySciences4-2.pdf>. Acesso em 10/02/2017. 